Universidade de São Paulo

Faculdade de Filosofia, Letras e Ciências Humanas

Departamento de Geografia

Programa de Geografia Humana

NATÁLIA FREIRE BELLENTANI

A territorialização dos monopólios no setor sucroenergético.

Versão Corrigida

São Paulo

2015 
Universidade de São Paulo

Faculdade de Filosofia, Letras e Ciências Humanas

Departamento de Geografia

Programa de Geografia Humana

\title{
A territorialização dos monopólios no setor sucroenergético*
}

\author{
Natália Freire Bellentani
}

Tese apresentada ao Programa de PósGraduação em Geografia Humana do Departamento de Geografia a Faculdade de Filosofia, Letras e Ciências Humanas da Universidade de São Paulo, para a obtenção do título de Doutora.

Orientador: Prof. Dr. Ariovaldo Umbelino de Oliveira

* Versão Corrigida.

"De acordo": Prof. Dr. Ariovaldo Umbelino de Oliveira

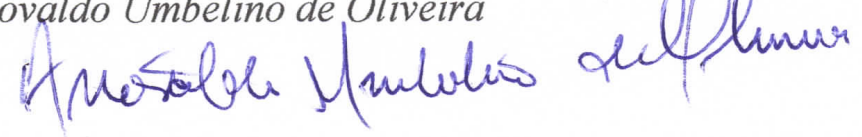

São Paulo 


\section{FOLHA DE APROVAÇÃO}

Nome: BELLENTANI, Natália Freire.

Título: A territorialização dos monopólios no setor sucroenergético.

Tese apresentada ao Programa de Pós-Graduação em Geografia Humana do Departamento de Geografia da Faculdade de Filosofia, Letras e Ciências Humanas da Universidade de São Paulo, para a obtenção do título de Doutora.

Aprovado em:

\section{Banca Examinadora}

$\operatorname{Prof}(\mathrm{a}) . \operatorname{Dr}(\mathrm{a})$ Instituição:

Julgamento: Assinatura:

Prof(a). Dr(a). Instituição:

Julgamento: Assinatura:

Prof(a). Dr(a). Instituição:

Julgamento: Assinatura:

Prof(a). Dr(a). Instituição:

Julgamento: Assinatura:

Prof(a). Dr(a). Instituição:

Julgamento: Assinatura: 
Aos povos indigenas, camponeses e trabalhadores que resistem à barbárie e seguem em luta contra o capital em favor de uma vida sem opressões. 


\section{AGRADECIMENTOS}

Agradeço aos fraternos amigos, militantes e companheiros

das trincheiras por onde sigo minha caminhada:

Associação dos Geógrafos Brasileiros;

Tribunal Popular;

Universidade Livre e Popular;

Universidade Estadual Paulista;

Universidade de São Paulo;

Pontifícia Universidade Católica - SP;

Aos queridos Rubão, D. Dirce,

Jussara, Bento Ary,

Pricila, Fabricio,

Eduardo,

Haidê, Anelis e Lúcia

minha gratidão e amor!

Aos pequenos

Arami,

Iayá e irmã(o),

Luiza e Eduardo

minha força para construirmos um mundo melhor! 


\section{Todas as Vidas}

Vive dentro de mim/ uma cabocla velha/ de mau-olhado,/ acocorada ao pé/ do borralho,/ olhando para o fogo./ Benze quebranto./ Bota feitiço.../ Ogum. Orixá./ Macumba, / terreiro./ Ogã, pai-de-santo... Vive dentro de mim/ a lavadeira/ do Rio Vermelho./ Seu cheiro gostoso/ d'água e sabão./ Rodilha de pano./ Trouxa de roupa,/ pedra de anil./ Sua coroa verde/ de São Caetano./

Vive dentro de mim/ a mulher cozinheira./ Pimenta e cebola./ Quitute bem feito./

Panela de barro./ Taipa de lenha./ Cozinha antiga/ toda pretinha./ Bem cacheada de picumã./ Pedra pontuda./ Cumbuco de coco./ Pisando alho, sal./

Vive dentro de mim/ a mulher do povo./ Bem proletária./ Bem linguaruda,/ desabusada, sem preconceitos,/ de casca-grossa,/ de chinelinha,/ e filharada.

Vive dentro de mim/ a mulher roceira./ Enxerto de terra,/ Trabalhadeira./ Madrugadeira./ Analfabeta./ De pé no chão./ Bem parideira./

Bem criadeira./ Seus doze filhos, / Seus vinte netos./

Vive dentro de mim/ a mulher da vida./ Minha irmãzinha.../

tão desprezada,/ tão murmurada.../ Fingindo ser alegre/ seu triste fado./

Todas as vidas/ dentro de mim:/ Na minha vida-/ a vida mera/ das obscuras!

(Cora Coralina) 


\title{
RESUMO
}

BELLENTANI, Natália Freire. A territorialização dos monopólios no setor sucroenergético. 2014. 175f. Tese (Doutorado) - Faculdade de Filosofia, Letras e Ciências Humanas da Universidade de São Paulo, São Paulo, 2014.

Este estudo de Geografia analisa o processo de territorialização dos monopólios no setor sucroenergético e discute a formação dos grupos econômicos agroindustriais monocultores territorializados. Seu intuito é compreender a concentração econômica e territorial, característica da agricultura mundializada, nesta etapa monopolista do capitalismo. As fusões territoriais monopolísticas que se constituem na expressão objetiva da territorialização dos monopólios são reveladas por todo o Estado de São Paulo, onde a agroindústria canavieira realiza o cultivo e o processamento da cana-deaçúcar. No caminho da análise, as contradições próprias do desenvolvimento capitalista tornam-se evidentes e a noção de exploração da força de trabalho neste setor, bem como a compreensão das formas de apropriação da renda da terra pelo capital, contribuem para explicar a relação entre agricultura e indústria e desvendar as especificidades dessas distintas atividades. Por tudo isso, destacam-se as alianças de classes e frações de classes (capitalistas industriais/ agrícolas/proprietários de terras) que são centrais no processo de territorialização dos monopólios no setor sucroenergético.

Palavras-chave: Setor sucroenergético; Território; Estado de São Paulo; Territorialização do Monopólio; Fusão territorial monopolística

\begin{abstract}
BELLENTANI, Natália Freire. The territorialization of monopolies in the sugar cane energetic sector. 2014. 175 f. Tese (Doutorado) - Faculdade de Filosofia, Letras e Ciências Humanas da Universidade de São Paulo, São Paulo, 2014.

This Geography study analyzes the process of territorialization of monopolies in the sugar cane energetic sector and discusses the formation of territorially monoculture agribusiness conglomerates. Your goal is to understand the economic and territorial concentration, characteristic of globalized agriculture, in the monopoly stage of capitalism. The monopolistic territorial fusions that constitute the objective expression of territorialization of monopolies are revealed throughout the state of São Paulo, where the sugarcane agribusiness holds the cultivation and processing of sugar cane. In the way of analysis, the contradictions of capitalist development become evident and the notion of exploitation of the workforce in this sector, as well as understanding of the forms of ownership of land rent by capital, help to explain the relationship between agriculture and industry and reveals the specificities of these different activities. For all that, there are the alliances of classes and fractions of classes (capitalist industrial / agricultural / land owners) that are central to the process of territorialization of monopolies in the sugar cane energetic sector
\end{abstract}

Key-words: Sugar cane energetic sector; territorialization of monopolies; monopolistic territorial fusion 


\section{LISTA DE ILUSTRAÇÕES}

Mapa 01: Escritórios de Desenvolvimento Rural - SP

Mapa 02: Área Plantada com cana-de-açúcar - 2003/2013 - I

Mapa 03: Área Plantada com cana-de-açúcar - 2003/2013 - II

Mapa 04: Área com cana-de-açúcar - SP (IEA/2013)

Mapa 05: Volume de produção de cana-de-açúcar - SP (IEA/2013)

Mapa 06: Expansão da cultura da cana-de-açúcar na região Centro-Sul (2007)

Mapa 07: Participação percentual da área plantada em relação à área do município - SP

Mapa 08: Zoneamento Agroambiental da cana-de-açúcar (2013)

Mapa 09: Unidades agroindustriais - Área de fornecimento de cana - SP (2013)

Mapa 10: Grupos monopolistas territorializados/ Unidades agroindustriais canavieiras (2013)

Mapa 11: Unidades agroindustriais - herdeiros família Ometto

Mapa 12: Raízen Energia S/A - SP Fusão territorial monopolística (2013)

Mapa 13: Biosev S/A Fusão territorial monopolística (2013)

Mapa 14: Tereos Internacional S/A Fusão territorial monopolística (2013)

Mapa 15: Grupos monopolistas territorializados - outros (2013)

Gráfico 01: Área Plantada (ha) com cana-de-açúcar no Brasil e no Estado de São Paulo $(1980-2010)$.

Gráfico 02: Produção de açúcar no Brasil e no Estado de São Paulo (1980 - 2013).

Gráfico 03: Produção de etanol no Brasil e no Estado de São Paulo (1980 - 2013).

Gráfico 04: Evolução da área (ha) e produção (t) de cana-de-açúcar para indústria (1984-2011) dos Escritórios de Desenvolvimento Rural (EDR) de Andradina e de Ribeirão Preto

Gráfico 05: Percentual de crescimento da área total agrícola ocupada com a produção de cana-de-açúcar, entre os anos de 1997 e 2008, nos municípios de Piracicaba, Ribeirão Preto, Jaú, Jaboticabal e Araras.

Gráfico 06: Percentual de crescimento da área total agrícola ocupada com a produção 
de cana-de-açúcar, entre os anos de 1997 e 2008, nos municípios de Lavínia, Guararapes, Rancharia, Palestina e Cafelândia

Gráfico 07: Valor de Terra Nua - Período: 2000 a 2014 - Moda (Terra de cultura de primeira $-\mathrm{R} \$ / \mathrm{ha}$ )

Gráfico 08: Arrendamento em Dinheiro (R\$/ha/ano) Período: 2000 a 2013

Figura 01: Clusters - Raízen Energia S/A

Figura 02: Estrutura societária Tereos Internacional S/A 


\section{LISTA DE TABELAS}

Tabela 01: Municípios que fazem parte dos Escritórios de Desenvolvimento Rural (EDRs) que produzem cana-de-açúcar há mais tempo.

Tabela 02: Municípios que fazem parte dos Escritórios de Desenvolvimento Rural (EDR) mais recentes no cultivo de cana-de-açúcar.

Tabela 03: Evolução da área (ha) plantada de cana-de-açúcar para indústria nas últimas três décadas nos Escritórios de Desenvolvimento Rural (EDR) de Piracicaba; Ribeirão Preto; Jaú; Jaboticabal; e Limeira

Tabela 04: Produção $(\mathrm{t})$ de cana-de-açúcar para indústria nas últimas três décadas nos Escritórios de Desenvolvimento Rural (EDR) de Ribeirão Preto, Piracicaba, Jaú, Limeira e Jaboticabal.

Tabela 05: Área (ha) plantada de cana-de-açúcar para indústria nas últimas três décadas nos Escritórios de Desenvolvimento Rural (EDR) de Andradina, Araçatuba, Presidente Prudente, São José do Rio Preto e Lins.

Tabela 06: Produção (t) de cana-de-açúcar para indústria no período de 2000 a 2011 , nos municípios dos Escritórios de Desenvolvimento Rural (EDR) de Andradina, Araçatuba, Presidente Prudente, São José do Rio Preto e Lins.

Tabela 07: Área total agrícola, área cultivada com cana-de-açúcar e percentual de canade-açúcar em relação a área total, entre os anos 1997 e 2008, nos municípios de Piracicaba, Ribeirão Preto, Jaú, Jaboticabal e Araras.

Tabela 08: Área total agrícola, área cultivada com cana-de-açúcar e percentual de canade-açúcar em relação a área total, entre os anos 1997 e 2008, nos municípios de Lavínia, Guararapes, Rancharia, Palestina e Cafelândia.

Tabela 09: Grupos Produtores de Açúcar e Álcool e capacidade de moagem no Brasil Anuário da Cana (2013)

Tabela 10: Grupos Produtores/Unidades agroindustriais de Açúcar e Álcool e localização municipal das unidades no Estado de São Paulo (2013)

Tabela 11: Ranking da moagem $(\mathrm{t})$ dos 10 primeiros Grupos Produtores de Açúcar e Etanol e suas Unidades Industrias no Estado de São Paulo - Anuário da Cana (2013)

Tabela 12: Ranking dos 10 primeiros Grupos Produtores de Açúcar e suas Unidades Industrias no Estado de São Paulo - Anuário da Cana (2013)

Tabela 13: Ranking dos 10 primeiros Grupos Produtores de Etanol e suas Unidades Industrias no Estado de São Paulo - Anuário da Cana (2013)

Tabela 14: Unidades agroindustriais do grupo monopolista Raízen Energia S/A

Tabela 15: Grupo Raízen S/A e a produção na safra 2012/2013 
Tabela 16: Área de plantio de arroz de sequeiro e várzea (ha). Período 2000-2013.

Tabela 17: Área (ha) de plantio de feijão das águas e da seca. Período 2000-2013.

Tabela 18: Área (ha) de plantio de mandioca. Período 2000-2013.

Tabela 19: Área (ha) de pastagem natural e cultivada. Período: 2000 a 2013

Tabela 20: Classificação da concentração fundiária no Estado de São Paulo - EDRs

Tabela 21: Valor de Terra Nua - Período: 2000 a 2014 - Moda (Terra de cultura de primeira $-\mathrm{R} \$ / \mathrm{ha}$ )

Tabela 22: Arrendamento em Dinheiro (R\$/ha/ano) Período: 2000 a 2013 


\section{LISTA DE QUADROS}

Quadro 01: Trajetória da Raízen Energia S/A

Quadro 02: Trajetória da Biosev S/A

Quadro 03: Trajetória da Tereos Internacional S/A 


\section{SUMÁRIO}

Introdução

I - Sobre os grupos monopolistas sucroenergético no capitalismo monopolista mundializado.

II - O processo de territorialização dos monopólios no setor sucroenergético.

III - A marcha da acumulação, concentração e centralização do capital e o setor sucroenergético.

IV - Os grupos monopolistas territorializados no setor

sucroenergético.

V - Consequências da expansão da territorialização do monopólio no setor sucroenergético no interior do Estado de São Paulo.

Considerações Finais

Referências 


\section{Introdução}

É cada vez mais comum, nos estudos econômicos e agrários, o debate acerca das fusões, aquisições, vendas e associações de empresas que atuam na produção e circulação de commodities ao redor do mundo. Para refletir sobre este período do capitalismo monopolista no campo brasileiro, coloca-se uma questão para ser respondida na dimensão geográfica dos fenômenos políticos: como se dá esse processo de expansão/retração/concentração do setor sucroenergético no Estado de São Paulo?

O setor sucroenergético atua simultaneamente, no controle da propriedade privada da terra, do processo produtivo no campo e do processamento industrial da produção, sendo exemplar para a compreensão de uma das lógicas econômicas que está dada nesta etapa monopolista do capitalismo, a territorialização dos monopólios.

O estudo da realidade concreta do setor sucroenergético, passa pela análise do processo contraditório do desenvolvimento do capitalismo no campo e coloca como centralidade teórica para este trabalho materialista dialético e histórico as relações sociais. São elas que preenchem cotidianamente a luta vigente entre as distintas classes que compõem a sociedade.

Sobre essa questão importa frisar que ao analisar os sujeitos em suas relações sociais, em suas relações de produção, aumenta o dever do pesquisador em participar das lutas sociais. E nesse sentido, o objetivo principal desse trabalho é dar uma contribuição para a discussão do processo de territorialização dos monopólios no setor sucroenergético. Processo este que vem sendo protagonizado pelos grupos econômicos agroindustriais monocultores territorializados. Formados, de maneira geral, por capitalistas industriais e agrícolas e proprietários de terra. Alianças de classe (ou frações 
de classe) que têm na exploração do trabalho e na apropriação da renda da terra seus pilares de sustentação.

Tendo traçado o objetivo da pesquisa, amparado sob uma perspectiva teórica materialista, buscou-se trabalhar com as noções, os conceitos e as ferramentas de análise da ciência geográfica que dão conta de apreender essas relações sociais, escapando de um recorte estritamente econômico e lógico-idealista.

Os defensores da primeira corrente estritamente econômica que atuam com dedicação aos trabalhos da chamada "Nova Geografia Econômica" expõem em seus conceitos os limites das análises quantitativas ${ }^{1}$. Expõem também, na perspectiva da produção da agroindústria canavieira a tendência a servir para engrossarem as estatísticas favoráveis as classes que comandam este e outros setores agropecuários. Neste conjunto consolida-se claramente a cooptação de pesquisadores pela Associação Brasileira do Agronegócio (ABAG), União da Indústria de Cana-de-açúcar (UNICA) e Confederação da Agricultura e Pecuária do Brasil (CNA), entre outras estruturas de representação de classe burguesa, que fomentam o discurso do crescimento econômico do agronegócio, por suas taxonomias de Produto Interno Bruto (PIB), renda, valor da produção e taxa de retorno, etc. Assim, professam e justificam efetivamente a lógica da expropriação, da acumulação e da desigualdade, em um fazer científico que não identifica a concentração econômica que está fortemente presente nesse setor.

Esse discurso acadêmico quantitativo e economicista se estabelece fortemente a partir da abertura econômica do país, na década de 1990, quando inicia-se um processo de concentração territorial, que advém das negociações de fusões e aquisições e que deu

\footnotetext{
${ }^{1}$ GERARDI, L. H. O.; SILVA, B. C. N., Quantificação em Geografia. Difel, São Paulo, SP, 1981. 161 p.; e KELLER, E.C.S. Tipos de agricultura no Paraná, uma análise fatorial. Revista Brasileira de Geografia, ano 32, n o 4, p.41 a 86, 1970.
} 
origem ao processo de territorialização. E mais, foi ainda reforçado nos anos 2000, com o vínculo entre o agronegócio e a agroenergia. Ao mesmo tempo em que uma aliança de classes em nível mundial, passou a acontecer e se fortalecer. Questões estas de extrema relevância e que serão trabalhadas ao longo desse texto e, necessariamente, não poderiam ser totalmente explicadas por este paradigma classista de ciência.

A segunda corrente que se expressa na produção de uma "Geografia Agrária e Econômica", está amparada em uma perspectiva lógico-idealista do espaço, cujas estruturas e objetos respondem pelos mecanismos de produção sócio-espacial ${ }^{2}$. Trata-se de uma corrente que em detrimento de análises que explicitam os processos sociais que se materializam, na pesquisa, em particular, não sinalizam na direção do processo de territorialização dos monopólios no setor sucroenergético, objetivamente, nas fusões territoriais monopolísticas. Dessa forma, não se mostra inteiramente capaz para apreender a totalidade deste debate.

Certo é que os instrumentos analíticos adotados por esses autores, não respondem a pergunta central desse trabalho, pois não dimensionam seus esforços teóricos para a essência dos processos de acumulação/exploração e reprodução social, considerando as centralidades que a mercadoria e a renda da terra reúnem nestas lógicas territoriais.

Assim, para fazer compreender essas lógicas o uso do referencial teórico da geografia agrária que está alicerçado na teoria do território tornou-se indispensável.

Na primeira parte do texto, será apresentado um estudo acerca do conceito de agroindústria, com o objetivo de não só esclarecê-lo em suas diferentes abordagens

\footnotetext{
${ }^{2}$ CASTILHO, R. e FREDERICO, S. Espaço geográfico, produção e movimento: uma reflexão sobre o conceito de circuito espacial produtivo. Sociedade \& Natureza, Uberlândia, 22 (3): 461-494, dez 2010.
} 
teóricas, mas também de reivindicá-lo como um conceito importante para a geografia agrária, onde são revelados e discutidos alguns pares dialéticos como o campo e a cidade e a indústria e a agricultura.

Na segunda parte do texto o debate acerca do território e da territorialização dos monopólios contribuirá para as análises da produção de cana-de-açúcar no Estado de São Paulo, apresentada na terceira parte através dos dados levantados junto ao Instituto de Economia Agrícola (IEA-SP) e Instituto Brasileiro de Geografia e Estatística (IBGE) que revelam como vem se dando o uso e a exploração do território.

$\mathrm{Na}$ quarta parte serão elencados e analisados os grupos monopolistas que se territorializam pelo Estado e para tanto se fez indispensável o uso dos mapas para a socialização dessas informações. E na parte final serão apresentadas algumas consequências da expansão da territorialização do monopólio no setor sucroenergético no interior do Estado de São Paulo. 


\section{I - Sobre os grupos monopolistas sucroenergéticos no capitalismo monopolista mundializado}

A produção capitalista do setor sucroenergético e as estratégias dos grandes grupos econômicos que passam a comandar este setor após a década de 1990 - quando ainda era controlado por empresas familiares nacionais - somadas ao controle do território pelos capitalistas burgueses e proprietários de terras no Estado de São Paulo, são processos que têm o poder de provocar arranjos territoriais significativos para a sociedade como um todo e, necessariamente, precisam ser investigados por meio da ciência geográfica.

Desde a preparação do solo e o plantio, passando pela escolha das variedades que serão cultivadas, tratos culturais, colheita e processamento, a produção de cana-deaçúcar se mostra, historicamente, como uma atividade econômica muito qualificada para a obtenção de altos rendimentos, em grandes propriedades, no Brasil. Quando se trata do cultivo e processamento desta cultura, a atenção ao debate deve voltar-se tanto para a agricultura, como para a indústria, ou seja, a classe social dos proprietários capitalistas de terra e os capitalistas da agricultura, dos industriais capitalistas burgueses e do proletariado agrário. Via de regra a classe dos proprietários capitalistas de terra e dos capitalistas da agricultura está fundida em uma mesma pessoa física ou jurídica, porém, representam diferentes classes sociais da sociedade capitalista (MARX, 1994).

A compreensão desse movimento que envolve a propriedade da terra, exploração agrícola e industrial - a tríade da agricultura capitalista sucroenergética no país - há tempos vem sendo descrita por diversos autores, com formas e conteúdos distintos, seja no meio acadêmico, político e/ou de comunicação. Há autores que traçam uma 
associação direta desse movimento aos conceitos de agronegócio, complexo agroindustrial e cadeias produtivas e que, de modo frequente, recaem na dualidade do campo e da cidade e na junção de classes distintas. Outros reconhecem a implantação do modo industrial de produzir no campo e analisam as relações contraditórias do campo e da cidade, indicando a unidade dialética desse par e não sua separação.

No caso do setor sucroenergético, assim como em outros setores que fazem parte da agricultura que se desenvolve sob o modo capitalista de produção, a maior parte das pesquisas realizadas e análises empreendidas, nas últimas décadas, revelam, justamente, a interdependência dos setores industriais e agrícolas como determinantes para o crescimento e o sucesso desses empreendimentos agropecuários.

Essa situação não é nova. Na década de 1970, Alberto Passos Guimarães já discorria, de modo amplo, sobre uma "nova categoria econômica", denominada “complexo agroindustrial”, que buscava explicar a integração da agricultura à indústria. Ao mesmo tempo, fornecia elementos para a compreensão da subvenção estatal que, de modo inequívoco, foi (e ainda é) determinante para o desenvolvimento das lavouras e para implantação/aperfeiçoamento das unidades processadoras, como, manifestamente, ocorre nos negócios realizados com a cultura da cana-de-açúcar.

Na ótica de Guimarães (1982), a partir do desenvolvimento da indústria, a agricultura perdeu sua hegemonia econômica e política na sociedade e também passou a ser uma atividade tributária do capital monopolista. Além disso, o autor admitiu que a formação do complexo agroindustrial nos países menos desenvolvidos tornou a agricultura um setor produtivo subordinado às empresas multinacionais.

Guimarães (1982), ao analisar as novas relações entre a agricultura e a indústria, esclareceu que o conceito de complexo agroindustrial: 
[...] surgiu na década de 1950, exatamente no período de mais intensa industrialização, como resultado dos estudos que, nos Estados Unidos e na Europa, começaram a ser empreendidos sobre a participação das atividades agrícolas nas relações intersetoriais, a partir das teorias a respeito dessas relações formuladas pelo Professor Wassily Leontief. Através da organização de quadros matriciais, obteve-se a comprovação empírica da justa medida em que a agricultura se estava tornando em consequência do processo de substituição dos métodos que produzem cana-de-açúcar a mais tempo pelos métodos industriais de produção, um elemento cada vez mais vinculado a um conjunto produtivo, em relação ao qual aumentava sua dependência. À medida que se industrializa, a agricultura passava de um nível inferior a um nível superior de desempenho, mas isso também significava uma perda progressiva de sua autonomia e de sua capacidade de decisão. Agora se tornaria possível apreciar as várias faces de um fenômeno que correspondia a um passo à frente inevitável, no curso do crescimento agrícola, mas que lhe haveria de trazer uma nova ordem de problemas. Ao aumentar sua dependência, de um lado em relação ao forte grupo de indústrias fornecedoras de insumos básicos; e, de outro, em relação às grandes indústrias transformadoras e compradoras da maior parte dos produtos agrícolas, a agricultura irá aumentar a sua produtividade, mas irá também aumentar seus custos, sem poder compensá-los com uma equivalente lucratividade. Isso também porque, entre outras razões, o mercado que nessa nova etapa se formará para seus produtos será menos livremente competitivo e tenderá a ser dominado, mais e mais, por condições monopolísticas (GUIMARÃES, 1982, p. 114).

Especificamente, no que se refere ao crescimento agrícola pautado pelo desenvolvimento industrial, o trabalho de Guimarães (1982) apontou aspectos positivos e negativos importantes. No caso dos efeitos prejudiciais, pode-se citar como exemplo a elevação dos custos de produção que aparece como uma consequência danosa deste processo, lado a lado com o declínio de lucratividade. A forte dependência da indústria e a perda de autonomia por parte dos agricultores também caracterizam aspecto negativo desta integração:

[...] os setores industriais fornecedores de insumos agrícolas só começam a implantar-se a montante da agricultura numa fase ulterior do desenvolvimento da economia, depois de um núcleo industrial de certa magnitude se haver instalado a jusante da agricultura e de este impor, à sua maneira, as quantidades e os tipos de produtos mais conformes com as exigências da transformação industrial. Os dois conjuntos de indústrias, um a montante e outro a jusante da produção agrícola, é que compõem, com a agricultura, o complexo agroindustrial (GUIMAR ÃES, 1982, p. 134.)

Assim, a posição teórica assumida por Guimarães submete a propriedade privada capitalista da terra à lógica da reprodução ampliada do capital, e, consequentemente, 
elimina-a da tríade - propriedade privada capitalista da terra, fração do capital agrícola e fração do capital industrial - assumindo, dessa forma, apenas a dualidade capital trabalho como centro gerador da contradição na luta de classes da sociedade. Eliminase, assim, o terceiro termo da tríade: a propriedade privada capitalista da terra e, com ela, a classe dos proprietários de terra.

No mesmo caminho, embora com uma postura distinta desta lógica de desenvolvimento técnico-produtiva que Guimarães (1982) apresentou, Geraldo Müller $(1981 / 89)$ relatou com rigor as relações entre o processo produtivo industrial e o processo produtivo agrário e, como Guimarães, utilizou a denominação “complexo agroindustrial" para tal processo de integração entre indústria e agricultura. A diferença fundamental entre os dois autores é que o primeiro admitiu a dualidade feudalismo $\mathrm{x}$ capitalismo na formação da sociedade brasileira, caminho teórico rechaçado por Müller.

De acordo com Müller (1981), para compreender o chamado complexo agroindustrial, deve-se atentar à interdependência dos setores industrial e agrícola.

[...] Em termos formais, o complexo ou sistema agroindustrial pode ser definido como um conjunto composto pela sucessão de atividades principais e acessórias vinculadas à produção e transformação de um ou mais produtos agrícolas. Dentre as atividades principais incluem-se a geração destes produtos, seu beneficiamento e transformação, a produção de bens de capital e de insumos industriais para as atividades agrícolas. Dentre as etapas acessórias, incluem-se a coleta, armazenagem, transporte, distribuição dos produtos industriais e agrícolas e o financiamento (MÜLLER, 1981, p. 8).

Para Müller (1981), faz-se necessário considerar o grau de interdependência entre agricultura e indústria, ao mesmo tempo em que se consideram todos os setores industriais a montante e a jusante da agricultura. Definido o complexo agroindustrial como esse processo de integração (total ou parcial), o autor não hesitou em afirmar que a agricultura, ainda que seja a atividade principal, pode estar subordinada aos setores industriais ou, até mesmo, a setores comerciais. 
As análises de Müller (1981) sobre esse movimento agrícola-industrial apontam para a distinção do campo e da cidade, privilegiando, abertamente, a indústria como determinante neste processo de interdependência, considerando relevante nesta relação, assim como outros autores, a integração técnica agricultura-indústria. Esta postura teórica é insuficiente para analisar, por exemplo, a manutenção da concentração da propriedade privada da terra e da renda fundiária nas mãos dos proprietários de terras e/ou aos capitalistas que, na minha avaliação, também se vinculam à integração de capitais entre agricultura e indústria.

Para Müller (1981), não há tríade, mas, dois pares contraditórios que se transformam em um único, ou seja, é a proposta teórica da relação entre a fração do capital na agricultura $X$ proletariado agrário e fração do capital na indústria $X$ proletariado fabril. Mas, como o capital na agricultura é o mesmo capital fabril, reduz as duas contradições em uma só: capital $X$ trabalho. Assim, não trabalha com as três contradições geradas nas relações sociais de produção: proprietário privado da terra (capitalista ou camponês) $X$ fração do capital na agricultura; fração do capital na agricultura $\mathrm{X}$ assalariados rurais e fração do capital fabril $\mathrm{X}$ proletariado industrial. Portanto, são três contradições geradas pelas lutas de classes, a saber: aquela entre o proprietário de terra e o capitalista da agricultura (que pode ser o mesmo industrial); aquela entre o capitalista da agricultura e o proletariado agrário, e aquela entre o capitalista industrial e o proletariado fabril. Assim, tanto Guimarães quanto Müller praticam o reducionismo teórico na compreensão da sociedade capitalista, vendo-a apenas pela contradição capital e trabalho.

Oliveira, na década de 1980, alertou para este novo caminho teórico, formulado a partir das obras de Martins: 
[...] Quando na agricultura o capitalista e o proprietário da terra são personagens distintas, objetivamente separadas e contrapostas, só após completado o processo todo é que o capitalista entrega (transferindo) ao proprietário a renda da terra. Quando ambos estão unificados em uma mesma pessoa, ele embolsa não só o lucro médio como também a renda da terra.

É fundamental esclarecer, que esta situação não elimina a contradição entre terra e capital, apenas a mascara. É por isso que quando o capitalista compra a terra, ele está comprando renda da terra, ou seja, o direito de apropriar-se de uma parte da mais-valia social. Aí reside uma diferença fundamental entre a terra e o capital, pois a terra sem produção alguma rende, ou como se diz comumente "se valoriza", e a condição de proprietário é requisito para se abocanhar parte dessa riqueza produzida socialmente. Esse fato decorre do monopólio que uma classe da sociedade detém sobre o meio de produção fundamental na agricultura; e reflete-se na parcela que a sociedade como um todo que tem que pagar, para que a produção dos alimentos possa continuar e ser produzida em quantidade necessária.

Quando ocorre a situação em que o capitalista e o proprietário da terra existem historicamente como classe antagônica, produtos da contradição entre terra e o capital, não significa que ambos deixaram de ser o que são na essência, proprietários dos instrumentos de produção, portanto, separados dos trabalhadores (únicos que podem colocá-los em movimento, ou seja, produzir).

Dessa forma, o monopólio de classe exercido pelos proprietários e pelos capitalistas é fundamental, no modo capitalista de produção, para submeter o trabalho dos trabalhadores, para que produzam, porque é assim que o capital se amplia. Assim, temos que diferenciar a terra e o capital, pois quando o capitalista compra a terra, ele transforma o seu capital em renda capitalizada (renda antecipada), pois a compra da terra nada mais é do que comprado direito de extrair renda da sociedade em conjunto. Essa diferenciação entre capital e propriedade fundiária é tanto maior quando procuramos entender o processo de acumulação a que estão submetidos; de um lado a concentração da propriedade da terra não leva necessariamente a um aumento de capacidade de produção mas sim aumenta o poder dos proprietários de se apoderarem de parte cada vez maior da massa de mais-valia global, que é distribuída entre eles pelo simples fato de serem proprietários privados da terra. $\mathrm{O}$ inverso ocorre com o capital que, estando concentrado, provoca o aumento da capacidade produtiva do trabalho, o que leva inevitavelmente ao aumento da capacidade do capitalista de extrair mais-valia. Já os proprietários podem escolher entre receber a renda da terra, parcela sob a forma de arrendamento (aluguel da terra), ou recebê-la de uma só vez quando da venda da terra. Estas diferenças entre a terra e o capital, suas contradições e movimentos antagônicos não querem dizer que não sejam personagens de dentro do modo capitalista de produção, pois o são. São produtos de relações sociais. Assim a propriedade fundiária não pode ser entendida como um entrave à expansão das relações capitalista de produção no campo, mas como contradição fundamental do modo capitalista de produção; é o tributo que o capital tem que pagar, sem o qual não poderá se expandir na agricultura e dominar o trabalho no campo (OLIVEIRA, 1981, p. 6/7)

Diferentemente do contexto apresentado por Guimarães e Müller, Graziano da

Silva (1993) reivindicou que o padrão agrícola brasileiro havia trazido os complexos

agroindustriais (CAIs) como unidades para a análise da agricultura. Reiterou que a 
constituição dos CAIs e a industrialização passaram a ser os novos determinantes da dinâmica da agricultura:

[...] A partir desse momento o desenvolvimento da agricultura não é mais autônomo, mas passa a depender da dinâmica da indústria; não se pode mais falar da agricultura como "grande setor" na economia (como na divisão tradicional agricultura-indústria-serviços), porque grande parte das atividades agrícolas integrou-se profundamente na matriz de relações interindustriais, sendo seu funcionamento determinado de forma conjunta (GRAZIANO DA SILVA, 1993, p. 32-33).

No tocante à forte presença da indústria na agricultura, conforme referida pelos autores, não se deve perder uma reflexão que aparece no centro da temática: a implantação do modo industrial de produzir que se estabeleceu no campo. Compreendese, aqui, que este movimento comporta a unidade contraditória do campo e da cidade. Logo, discordando dos autores citados, este par campo-cidade não pode ser trabalhado como dualidade, sendo necessário desvendá-lo enquanto movimento dialético que encerra a tríade: propriedade privada capitalista da terra, capital (agrícola e industrial) e o trabalho.

Entende-se que as relações interindustriais, em sua mediação com a agricultura, devem ser compreendidas no âmbito das relações capitalistas de produção e, isto posto, no que tange à reflexão do campo brasileiro, inicia-se um debate acerca da presença do trabalho assalariado na agricultura.

$\mathrm{Na}$ produção da agricultura capitalista, que visa unicamente o lucro, dados alarmantes relativos à exploração dos trabalhadores têm sido amplamente veiculados e ações ainda muito tímidas vêm sendo tomadas ${ }^{3}$ por parte do poder legislativo e

3 [...] a Organização Internacional do Trabalho (OIT) se manifesta a favor da legislação brasileira de
combate ao trabalho escravo. O relatório global da entidade elogiou a definição de escravidão prevista na
lei brasileira e citou o Brasil como referência mundial no combate ao trabalho escravo. Em agosto deste
ano, a advogada Gulnara Shahinian, Relatora Especial da ONU para formas contemporâneas de
escravidão, enviou uma carta aos senadores cobrando a imediata aprovação da PEC do Trabalho Escravo.
Em sua avaliação, o artigo 149 do Código Penal atende plenamente ao que está previsto nas convenções 
executivo. No setor sucroenergético, esses abusos também aparecem como regra e não como exceção. O trabalho análogo à escravidão ou peonagem, não se desvincula deste setor por uma razão de fácil compreensão, mas de inequívoca indignação: o proprietário capitalista da terra quer se apropriar da renda da terra máxima possível.

Esta forma de violência brutal que derrama o suor e o sangue dos trabalhadores nos canaviais paulistas já matou mais de 26 trabalhadores nos anos 2000 e segue cotidianamente tensionando o corpo do trabalhador ao limite da capacidade humana de trabalhar (ALVES, 2006).

[...] Para cortar 6 toneladas de cana em um dia, considerando uma cana de primeiro corte, de crescimento ereto, o comprimento do eito deve ser de aproximadamente 200 metros. Isso significa que a área total desse eito é de $1.200 \mathrm{~m}^{2}$ (200 m de comprimento por $6 \mathrm{~m}$ de largura); nele o trabalhador realiza as seguintes atividades: Corta a cana rente ao solo, desprendendo as varas das raízes; Corta a ponteira da cana, que é a parte de cima, onde estão as folhas verdes, que não têm sacarose e, portanto, não servem para as usinas; Transporta a cana cortada em cada rua para a rua central; Arruma a cana em montes ou esteirada na rua central. [...]

[...] o que vai ao centro da questão, que são as mortes dos trabalhadores cortadores de cana pelo excesso de trabalho, é o fim do pagamento por produção. Enquanto o setor sucroalcooleiro permanecer com essa dicotomia interna - de um lado, utiliza o que há de mais moderno em termos tecnológicos e organizacionais, uma tecnologia típica do século XXI (tratores e máquinas agrícolas de última geração, agricultura de precisão, controlada por geoprocessamento via satélite etc.), de outro lado, mantém relações de trabalho, já combatidas e banidas do mundo desde o século XVIII -, trabalhadores continuarão morrendo. Isso porque os 14 que morreram nas duas últimas safras são, infelizmente, uma amostra insignificante do total que poderá morrer todas as safras clandestinamente, silenciosamente. [...] (ALVES, 2006, p. 92.).

No Estado de São Paulo, esta realidade, que mantém entrelaçada “a modernidade" do agronegócio à barbárie provocada, principalmente, contra os trabalhadores, é explicitada por Thomaz Jr. (2007), apontando a questão da extrema exploração dos trabalhadores nos canaviais de forma contundente:

internacionais contra trabalho forçado das quais o Brasil é signatário. (Por Stefano Wrobleski, Nov de 2013. Disponível em: <www.trabalhoescravo.org.br/noticia/74>. Acesso em: Junho de 2014.) 
[...] Para atingir os mesmo patamares de ganhos de dez anos atrás, os trabalhadores, hoje, têm que cortar muito mais. Os percentuais podem atingir aproximadamente 40 a $60 \%$, ou seja, por todos os motivos, não é compensador cortar cana, sobretudo porque os menores ganhos estão associados à perda precoce da vida útil e a uma série de aspectos e critérios pré-estabelecidos para a composição das turmas, a cada safra. A começar pela faixa etária e sexo, quando se decide por trabalhadores de 18 a 25 anos de idade, local de origem, isto é, a preferência dos capitalistas e gatos/agenciadores é pelos migrantes, os quais resistem menos às precárias condições de trabalho no eito e de vida nos barracões, alojamentos, pensões etc. Para a manutenção e expansão desse esquema, as empresas se utilizam dos sofisticados programas computacionais e sistemas informatizados, que possibilitam o controle individualizado dos trabalhadores, influenciando sobremaneira tanto no corte do contingente que não interessa e que pode ser descartado, quanto na seleção dos melhores e mais aptos ao trabalho e à aceitação das imposições e desmandos (THOMAZ Jr 2007, p. 24)

Do mesmo modo, a professora Maria Aparecida Moraes Silva, em seus trabalhos

dentro da Sociologia e também na Geografia, discorreu a respeito do impacto dessa

exploração, tanto (por enquanto) para os próprios sujeitos rendidos a essa condição, como também aos seus familiares. No tocante a essa questão, a autora relatou que:

[...] Outro dado extraído destes registros/denúncias se reporta à superexploração desta força de trabalho, a ponto de extrapolar os limites físicos, ocasionando as mortes nos canaviais. Somente neste ano de 2004, A Pastoral dos Migrantes registrou três mortes, provocadas pelo excesso de esforço, uma verdadeira overdose do trabalho, denominada "birola", pelos trabalhadores. Além das condições alimentares insuficientes - causadas pelos baixos salários, do calor excessivo, do elevado consumo de energia, em virtude de ser um trabalho extremamente extenuante -, a imposição da média, ou seja, da quantidade diária de cana cortada, cada vez mais crescente, tem sido o definidor do aumento da produtividade do trabalho, principalmente, a partir da década de 1990, quando as máquinas colhedeiras de cana passaram a ser empregadas em números crescentes. Esta imposição atinge não somente os migrantes como também os trabalhadores locais. Por esta razão, estes capitais necessitam de mão de obra jovem, dotada de muitas energias, para o desempenho desta atividade. Assim, a rotatividade torna-se muita alta, em virtude da reposição constante da força de trabalho, consumida durante o processo produtivo.

Em síntese, do conjunto de registros/denúncias acima descrito, três foram as questões levantadas pela presente análise: a segmentação da força de trabalho, a partir da divisão étnica do trabalho, sem contar a questão de gênero, pois as mulheres foram praticamente alijadas do corte da cana, imobilização da força de trabalho de migrantes, muitos dos quais sujeitados aos gatos em virtude das dívidas contraídas e alojados em condições extremamente precárias; a superexploração, responsável por algumas mortes durante o processo de trabalho (SILVA, 2005, p. 213/14) 
Sob a lógica da ordem burguesa a dinâmica capitalista implica, necessariamente, na concentração simultânea dos capitais e da propriedade privada da terra no setor sucroenergético, e, isso se confirma, considerando este processo de superexploração dos assalariados rurais, paralelamente à facilitação encontrada pelos grupos econômicos para a concentração e centralização dos capitais por meio dos instrumentos da economia de mercado, como fusões, associações e aquisições que se processam atualmente de forma rotineira.

Levando em conta os questionamentos teóricos, metódicos e filosóficos, que envolvem esses processos monopolistas que comandam a produção agrícola no Brasil, avalia-se ser necessário assumir as relações sociais determinantes para este debate e, deste modo, assumir a sociedade como totalidade e analisar como as distintas classes que compõem esta realidade participam desse processo, que caracteriza a faceta do modo capitalista de produção no campo brasileiro.

As tecnologias introduzidas nesse setor específico, seja no processo produtivo agrícola e/ou industrial, remetem há séculos passados. Sendo considerada por alguns autores como a primeira indústria a se efetivar no Brasil, tanto pela introdução do arado no campo como na produção de energia para as caldeiras. No século XVI, tratava-se, em ambos os casos, de práticas que confirmam as análises vinculadas à interdependência da agricultura e da indústria.

Assim, é importante lembrar que o caminho teórico para o estudo do campo brasileiro, pós-década de 1970, passa por esta dinâmica de reprodução ampliada do capital e, para se entender o processo de modernização da agricultura no Brasil, principalmente em São Paulo, deve-se considerar as contradições da industrialização da agricultura. 
No presente trabalho reitera-se que o processo integração agricultura-indústria está em consonância com as formas de produção capitalista, ressaltando que Oliveira (2005) insistiu na necessidade de considerar que:

[...] A industrialização da agricultura revela, assim, que o capitalismo está contraditoriamente unificando o que ele separou no início do seu desenvolvimento: indústria e agricultura. Essa unificação está sendo possível porque o capitalista se tornou também proprietário das terras, portanto, latifundiário. Isto se deu também porque o capital desenvolveu liames de sujeição que funcionam como peias, como amarras ao campesinato, fazendo com que ele produza, às vezes, exclusivamente para a indústria. Um exemplo desse processo ocorre com as usinas ou destilarias de açúcar e álcool, onde atualmente indústria e agricultura são partes ou etapas de um mesmo processo. Capitalista da indústria, proprietário de terra e capitalista da agricultura têm um só nome, são uma só pessoa. Para produzir utilizam-se do trabalho assalariado, dos bóias-frias que moram/ vivem nas cidades (OLIVEIRA, 2005, p.105)

A partir dessa avaliação, é possível entender o caminho teórico construído por Oliveira (2005), que assumiu as relações sociais em sua totalidade e particularidades, e apresentou como centralidade a sociedade com suas classes distintas, não excluindo as questões relativas à interdependência dos setores, complementando-as.

Ao mesmo tempo, fica claro, ainda que de forma sucinta, que a agricultura aqui não se coloca de forma subordinada à indústria. Recordando que, do ponto de vista econômico, o primeiro momento da reprodução ampliada do capital, a produção, não pode ser considerado como fator menos importante que os demais; pelo contrário, entende-se aqui, a partir de uma leitura crítica da realidade, que sem este momento específico não é possível a realização dos demais (distribuição, circulação e /ou consumo $)^{4}$.

Sendo assim, por meio da investigação dos fatos e das abstrações que compõem as múltiplas determinações dos processos históricos, bem como da realidade fundiária e fabril canavieira no Estado de São Paulo, é possível afirmar que o processo de

\footnotetext{
${ }^{4}$ MARX, Karl (1859). Para a crítica da economia política. In MARX, K. Para a crítica da economia política; Salário preço e lucro; O rendimento e suas fontes. São Paulo: Abril Cultural, 1982.
} 
desenvolvimento do modo capitalista de produção em sua etapa monopolista no campo brasileiro é, hoje, celebrado e coroado pelo novo ciclo de expansão da monocultura de cana-de-açúcar, para a produção de açúcar, álcool e energia elétrica.

Excetuando-se parcos momentos de crises, contraditoriamente inerentes a este processo de produção, o setor sucroenergético, como hoje é reconhecido, tem um histórico de crescimento marcado por políticas favoráveis, desde o período colonial e, tradicionalmente, associadas à perspectiva de acumulação e valorização do valor ${ }^{5}$ deste setor.

O alastramento deste setor no interior do Estado de São Paulo, nas últimas décadas, é o exemplo com o qual se irá trabalhar, a fim de expressar o processo de territorialização do monopólio, marcado pela capitalização e concentração da estrutura agrária. Tal territorialização se expressa, de forma objetiva, pelos diversos exemplos de fusões territoriais monopolísticas dos grupos produtores de cana-de-açúcar no Estado de São Paulo.

Destaca-se que a monocultura canavieira destinada à indústria, na última década, esteve presente em 79,68\% dos municípios do Estado de São Paulo, como indica o Instituto de Economia Agrícola, ou seja, dos 645 municípios do Estado, pelo menos 514 produziram cana-de-açúcar. (IEA, 2012).

Tendo como base de análise a regionalização da Secretaria de Agricultura e Abastecimento (SAA), que agrupa os 645 municípios em 40 Escritórios de Desenvolvimento Rural (EDRs), pode-se observar mais adiante nesta pesquisa que a

\footnotetext{
5 “A circulação do dinheiro como capital é, uma finalidade em si mesma, pois a valorização do valor só existe dentro desse movimento sempre renovado. Por isso o movimento do capital é insaciável." KARL, Marx. O Capital. Crítica da Economia Política. Livro Primeiro: O Processo de Produção do Capital. Tomo 1. São Paulo: Nova Cultural Ltda. 1996.
} 
produção canavieira se expande, fundamentalmente, sobre áreas anteriormente produtoras de citros e pecuária, além de áreas de grãos, frutas e olerícolas do Estado de São Paulo. (Mapa 01) 


\section{ESCRITÓRIOS DE DESENVOLVIMENTO RURAL - SP}

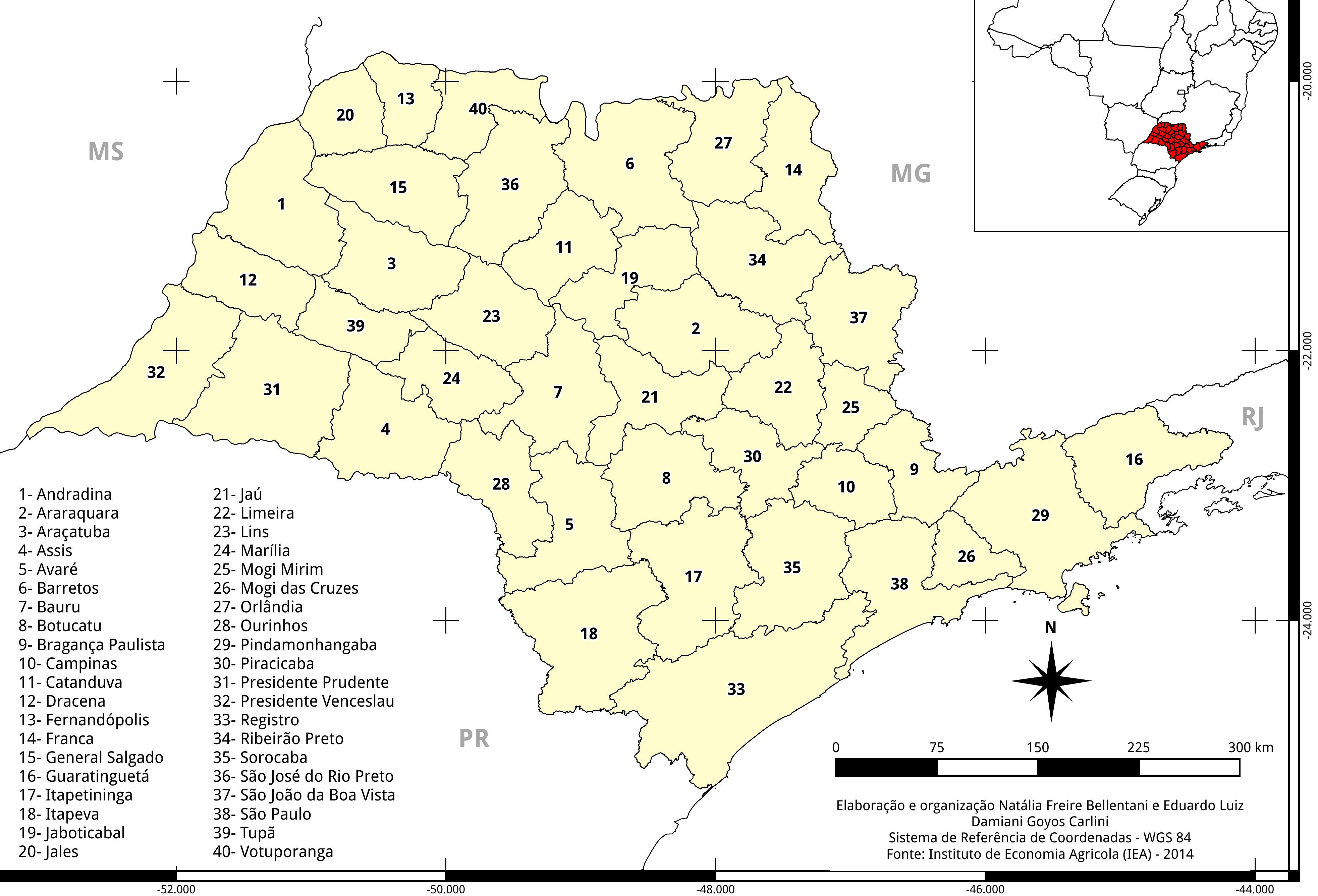


Primeiramente, interessa compreender como ocorre esse processo de expansão/retração/concentração territorial do setor para, posteriormente, analisar se a área de produção de cana-de-açúcar tem aumentado/diminuído/concentrado, as modificações territoriais ocorridas no Estado de São Paulo, a partir da década de 1990 e, por fim, verificar as consequências dessas e outras transformações, a partir do período de abertura econômica neoliberal do país.

De maneira sintética, deve-se lembrar que, do ponto de vista quantitativo, o Estado de São Paulo possui área total de cerca de 24,9 milhões de hectares, com área agricultável de, aproximadamente, 14,7 milhões, dos quais a área destinada à produção canavieira para a indústria alcançou $41,0 \%{ }^{6}$, e a ocupação do solo com áreas preservadas ficou em torno de 22\% (IEA, 2012). Em 1990, esta percentagem estava em torno de $19,3 \%$ e a porção com áreas preservadas representava 14,3\%. São justamente os efeitos deste uso do solo no Estado de São Paulo, bem como algumas mudanças anunciadas e outras ainda obscuras em relação ao setor que precisam ser analisadas, ao mesmo tempo em que se considera a conjuntura de crise.

Paralelamente, é imprescindível salientar que, para adentrar nesta realidade, fazse necessário reforçar um ponto muito importante deste debate: as agroindústrias e os grupos empresariais monopolistas. Em primeiro lugar deve-se destacar a formulação do conceito de agroindústria, o qual, embora tenha se originado no bojo dos trabalhos de

\footnotetext{
${ }^{6} \mathrm{~A}$ área cultivada com cana-de-açúcar que será colhida e destinada à atividade sucroalcooleira na safra 2013/14 está estimada em 8.799.150 mil hectares, distribuídas em todos estados produtores conforme suas características. O estado de São Paulo permanece como o maior produtor com 51,31\% (4.515.360 hectares) da área plantada, seguido por Minas Gerais com 8,0\% (781.920 hectares), Goiás com 9,3\% (818.390 hectares), Paraná com 7,04\% (620.330 hectares), Mato Grosso do Sul com 7,09\% (624.110 hectares), Alagoas com 5,02\% (442.590 hectares) e Pernambuco com 3,25\% (286.030 hectares). Nos demais estados produtores as áreas são menores, com representações abaixo de 3,0\%. A área de cana-deaçúcar destinada à produção neste ano safra deve apresentar um crescimento de $3,70 \%$ ou 314.150 hectares em relação à safra passada. $\mathrm{O}$ aumento só não será maior por causa da intenção de plantio do Norte/Nordeste apresentar uma leve queda em relação à safra passada. A área de renovação e/ou novas áreas de canaviais previstas para acontecer na atual temporada é estimada em $16,92 \%$ das lavouras atuais. (Disponível em: <www.conab.gov.br/OlalaCMS/uploads/arquivos/13_08_08_09_39_29_boletim_cana
} portugues_-_abril_2013_1o_lev.pdf $>$. Acesso em Jan 2014.) 
Guimarães (1976) Müller (1989) e Graziano da Silva (1993) nesta tese é seguida a proposta teórica de Oliveira ${ }^{7}$.

[...] Sem dúvida alguma a agroindústria açucareira, particularmente a paulista, representa hoje o exemplo mais significativo do processo de monopólio na produção com consequente subordinação da circulação aos desígnios da produção. Repete-se, nesse caso, o processo de desenvolvimento do capitalismo industrial, onde a circulação está completamente submetida à produção, pois cada vez mais a mercadoria sai da produção com o preço de venda ao consumidor estipulado, consequentemente o custo de mercadoria para o comerciante também.

Muitos são os trabalhos que já têm demonstrado que a expansão da agroindústria açucareira se fez a partir da mudança de base social da produção, pois é com essa expansão que o trabalhador temporário ganha expressão no conjunto da força de trabalho no campo.

Pois agora o capitalista já não precisa manter (pagar) o trabalhador no chamado período de entressafra, quando a produção praticamente cessa. $\mathrm{O}$ trabalhador temporário é aquilo que Marx chamou de trabalhador nu, desprovido dos instrumentos da produção, que apenas dispõe da sua força de trabalho para vendê-la no mercado, resultando, dessa venda, a garantia (ou não) da sua reprodução (OLIVEIRA, 1983/2010, p. 21).

Importa também, lembrar que os dois produtos pautados neste trabalho são o açúcar e o etanol (anidro e hidratado), visto que são os que colocam o setor em funcionamento. Paralelamente, esclareço que a commodity que comanda o setor é o açúcar e não, como muitos querem fazer crer, o etanol ${ }^{8}$.

No segmento da agroindústria, que se refere a essa integração entre a agricultura e a indústria, conforme exposto, a agroindústria canavieira está no foco desta pesquisa, referindo-se, tanto ao cultivo da cana-de-açúcar, como à produção industrial de açúcar,

\footnotetext{
${ }^{7}$ OLIVEIRA, A. U. . Agricultura e Industria No Brasil. BOLETIM PAULISTA DE GEOGRAFIA, São Paulo, n.57, p. 5-64, 1983.

${ }^{8}$ [...] O plantio de cana-de-açúcar para a produção de álcool ocorre de forma intensa e significativa, apenas no Brasil. Assim, cabe deixar claramente explicitado que o etanol não é uma commodity internacional. Têm ocorrido tentativas por parte do Brasil, para procurar transformar este produto em mercadoria internacional, mas, ele ainda não o é. Dessa forma, o etanol de cana-de-açúcar tem se tornado um combustível importante apenas no Brasil. Este fato está relacionado historicamente com as políticas públicas voltadas para o setor. Entre elas cabe destacar o desenvolvimento de tecnologia para produção do motor movido a álcool e mais recentemente ao motor flex. (OLIVEIRA, A. U.. Os Agrocombustíveis e a Produção de Alimentos. In: Mirian Claudia Lourenção Simonetti. (Org.). A (in) sustentabilidade do desenvolvimento: meio ambiente, agronegócio e movimentos sociais. 1a.ed.São Paulo/Marília: Cultura Acadêmica/Oficina Universitária, 2011, v. 1, p. 159-180.)
} 
álcool, energia elétrica e alguns subprodutos (bagaço, óleo fúsel, levedura seca, vinhaça, melaço, torta de filtro, entre outros).

Para que se possa compreender o desenvolvimento da agroindústria canavieira no Brasil, é preciso dialogar, observando as distintas fases que compõem o avanço do setor e os momentos históricos que corroboram com essa dinâmica, a partir do século XX. Além disso, faz-se imprescindível elencar e discutir o papel decisivo do Estado brasileiro neste processo de industrialização da agricultura.

Em períodos como, por exemplo, da crise econômica de 1929, ou da Segunda Grande Guerra, de 1939 a 1945, e também da Guerra Fria, a partir de 1945 até 1989, os mercados de açúcar e álcool sofreram reflexos diretos e indiretos em todo o mundo e o Brasil não foi exceção a nenhum destes casos. De acordo com a periodização estabelecida por Ramos (2008), entre 1930 e 1965, a produção canavieira-açucareira em São Paulo foi ampliada em função dos investimentos dos cafeicultores e neste momento histórico, o mercado interno ainda era o alvo principal. Szmerecsányi (1979) ampliou este debate, discorrendo, detalhadamente, acerca do processo de planejamento que é desenvolvido no Estado brasileiro no referido período, ao garantir, fundamentalmente, apoio financeiro ao desenvolvimento da agroindústria canavieira do país.

[...] São Paulo iniciou a década de 1930 com uma produção açucareira em plena expansão, também em decorrência dos resultados bastantes positivos alcançados pela propagação das novas variedades de cana, introduzidas para substituir as que haviam sido quase dizimadas devido ao advento do mosaico, em meados dos anos 1920, o qual também causara estragos no Rio de Janeiro, mas numa proporção menor, ao que tudo indica. As novas variedades colocaram a produção paulista num patamar superior àquele em que estivera bem antes do advento do mosaico, potencializando seus rendimentos e estimulando a realização de novos investimentos no setor (SZMERECSÁNYI, 1979, p. 43)

Nesta trajetória do mercado canavieiro, Szmerecsányi (1979) e Ramos (2008) referem-se ao período da Segunda Grande Guerra e pós-guerra, englobando, desde 
questões pontuais geradas pela guerra submarina que comprometera o transporte marítimo do açúcar e as inocorrências geradas no abastecimento interno, principalmente em São Paulo, passando pelas consequências provocadas pelo conflito mundial que prejudicavam o abastecimento de gasolina, por exemplo, fator que viabilizou políticas de investimento ao setor para a produção ao álcool, mas, ao mesmo tempo, não garantia as importações de benzeno, produto necessário para a obtenção do álcool anidro. $\mathrm{Na}$ afirmação de Szmerecsányi (1979), “tendo em vista a falta de açúcar em São Paulo, os produtores acabavam preferindo concentrar-se na sua produção".

[...] Durante Segunda Grande Guerra o IAA, também passou a enfrentar os problemas relativos ao abastecimento da gasolina, desenvolvendo uma política de estimulo à produção 'álcool motor', incentivando a constituição de novas destilarias e a conversão daquelas que até então produziam a pena aguardente. Contudo, deve ser salientada a maior expansão da produção de álcool não se deu, não durante, mas antes da guerra, por duas razões: a primeira, porque o conflito mundial também dificultou as importações de benzeno, produto necessário para a obtenção do álcool anidro, a segunda, porque, tendo em vista a falta de açúcar em São Paulo, os produtores acabavam preferindo concentrar-se na sua produção. (SZMERECSÁNYI, 1979, p.9/10).

Neste período, ainda de acordo com o autor "o complexo canavieiro paulista passou a ter no seu interior, uma indústria de equipamentos em pleno desenvolvimento".

[...] A cana-de-açúcar é uma matéria prima de aproveitamento múltiplo, cujos produtos intermediários são dotados de grande versatilidade, podendo ser submetidos a vários tipos de processamento industrial, e dando origem a numerosos derivados e subprodutos.

[...] Essa diversidade que poderá acentuar-se no futuro, não é peculiar apenas à moderna agroindústria canavieira, na qual figuram além das usinas de açúcar, algumas grandes destilarias autônomas de álcool e aguardente. Ela ocorre também no artesanato canavieiro, onde as pequenas destilarias de aguardente nem sempre se acham acopladas a engenhos açucareiros, constituindo muitas vezes pequenas indústrias rurais autônomas e especializadas. (SZMERECSÁNYI, 1979, p. 130) 
Posteriormente, ainda sobre este contexto mundial, ocorreu o bloqueio econômico sobre Cuba, exercido pelos Estados Unidos da América, via Organização dos Estados Americanos (OEA). Este embargo, mantido até hoje, garantiu aos demais países produtores de açúcar as cotas do açúcar cubano que atendiam ao mercado norteamericano. Neste período entre os países produtores de açúcar (Brasil, Peru, Colômbia, Republica Dominicana, Jamaica e outros países do Caribe e América Central), o Brasil foi o país que recebeu a maior cota para a produção.

Para "alavancar a modernidade", como salientou Szmerecsányi, o Estado brasileiro propôs distintas políticas que visaram contribuir neste processo.

[...] O período que vai do pós-guerra até o final de 1960 é de fundamental importância para entender - nos seus devidos termos - a configuração estrutural da agroindústria canavieira do Brasil, vale dizer, do complexo produtor de cana/açúcar/álcool do país [...] Essa configuração vem se mantendo até hoje, e foi explicitamente sedimentada nos períodos subsequentes.

[...] As unidades de processamento dos produtos agropecuários integram a chamada agroindústria, que geralmente desempenha um papel de grande importância nas primeiras etapas de industrialização das economias menos desenvolvidas. Não se trata de um único ramo industrial, mas de um grupo muito variado de estabelecimentos, com as mais diversas escalas e técnicas de produção, e bastante heterogêneo quanto à densidade de uso do fator capital. Sua existência se deve a necessidade de submeter à maioria dos produtos agropecuários a determinadas transformações entre a 'colheita' e o consumo final dos mesmos. (SZMERECSÁNYI, 1979, p. 27)

Esse movimento apresentado por Szmerecsányi teve uma dinâmica que

atravessou séculos na história do nosso país e como o próprio autor afirmou, o desenvolvimento da agroindústria canavieira teve um papel de grande relevo na história econômica do Brasil.

[...] A importância econômica da cana-de-açúcar deriva do número e da função de seus usos alternativos. Planta industrial por excelência, ela não apenas constitui matéria prima para a fabricação de um alimento básico do homem - $\mathrm{o}$ açúcar - mas dá origem também a numerosos derivados e subprodutos, todos de grande utilidade - como o melaço, o álcool, a aguardente, fermento para panificação, celulose, proteína para rações, fertilizantes, etc. Devido ao seu valor de mercado, a cultura da cana-deaçúcar representa uma importante fonte de renda e de emprego para ponderáveis parcelas da população rural. Por outro lado, a ela se vincula 
diretamente um grande parque fabril -as usinas de açúcar, destilarias de álcool, etc. - o qual também gera renda e empregos, e cuja produção tem amplo consumo doméstico e industrial, tanto dentro como fora do país. (SZMERECSÁNYI, 1979, p. 76)

Do ponto de vista da unificação da agricultura e da indústria como apontou o autor, não é possível desconsiderarmos a ação do capital no campo e na cidade e mais, o poder do Estado que segue sendo controlado pelas classes dominantes. E é nesse sentido que para o autor, os proprietários de terras, bem como os capitalistas se tornam o mesmo sujeito dentro desse setor.

Ramos reiterou essa perspectiva, afirmando que:

[...] O usineiro no Brasil é, antes de tudo, um proprietário fundiário. Portanto, nunca houve - e não há - contradição entre a produção industrial e a produção agrícola no caso; mais ainda, propriedade industrial e a propriedade fundiária. Portanto não há 'dois grupos dirigentes' a se oporem e a disputarem a retenção de uma maior parcela do excedente gerado. (RAMOS, 1999 p. 23/4)

Por outro lado é salutar lembrar que o aporte teórico que sustenta tal perspectiva, vinculando as classes de proprietários de terra aos industriais burgueses encontra debates no campo teórico. Historicamente, como afirmou Oliveira (2014, Obra Inédita) não há a junção destas duas classes sociais distintas, o que ocorre é que no caso do setor sucroenergético o proprietário da terra, do capital agrícola e do capital industrial é mesma pessoa física ou jurídica, porém, classes sociais e frações de classe distintas. Reitero a citação já apresentada anteriormente:

[...] Quando na agricultura o capitalista e o proprietário da terra são personagens distintas, objetivamente separadas e contrapostas, só após completado o processo todo é que o capitalista entrega (transferindo) ao proprietário a renda da terra. Quando ambos estão unificados em uma mesma pessoa, ele embolsa não só o lucro médio como também a renda da terra. É fundamental esclarecer, que esta situação não elimina a contradição entre terra e capital, apenas a mascara. É por isso que quando o capitalista compra a terra, ele está comprando renda da terra, ou seja, o direito de apropriar-se de uma parte da mais-valia social. Aí reside uma diferença fundamental entre a terra e o capital, pois a terra sem produção alguma rende, ou como se diz comumente "se valoriza", e a condição de proprietário é requisito para se 
abocanhar parte dessa riqueza produzida socialmente. (OLIVEIRA, A. U. 1983. p. 6/7.)

De todo modo, no que tange a formulação de políticas públicas que atenderam a agroindústria canavieira e contribuíram para o fortalecimento da classe dos proprietários de terra e dos capitalistas burgueses, não faltam exemplos.

Com a "Crise do Petróleo", por exemplo, o Proálcool foi criado como um programa de financiamento para o desenvolvimento/crescimento do setor e mobilizou na década de 1970, mais $\mathrm{R} \$ 5$ bilhões só para agroindústria canavieira. O que importa dizer nesta relação público-privada é que essas contas não são pagas, esses financiamentos se tornaram dívidas que não têm sido acertadas.

É preciso destacar que muitas vezes este dinheiro público acessado por meio deste tipo de financiamento pode ser aplicado no processo produtivo ou ser usado para salvar dívidas, entrar no sistema especulativo financeiro e/ou ser imobilizado em outros investimentos.

Na prática, como analisou detalhadamente Szmerecsányi, esse setor nos anos 1970 tinha uma dependência muito forte dos financiamentos públicos. Como o autor advertiu, esses recursos financeiros obtidos por meio de empréstimos em longo prazo, foram determinantes para alavancar a agroindústria canavieira e nesta relação públicoprivada os capitalistas-proprietários de terra não precisavam retirar recursos do processo produtivo. Ou seja, nem mesmo uma pequena fração da massa de mais valia era recolhida.

E não pode ser desconsiderado neste processo que o ritmo dado ao desenvolvimento/crescimento do setor sucroenergético revela uma hegemonia do capital monopolista, a qual condiciona sua expansão, inclusive no interior do Estado de São 
Paulo, principalmente, após a crise do petróleo de 1973, e deste modo provocou transformações abruptas no campo e na cidade.

Seja nas décadas de 1970, 1980, 1990, ou 2000 esta prática que diz respeito aos empréstimos e financiamentos, nos distintos governos do Estado brasileiro variaram, mas nunca deixaram de existir. Desde a política/aparato jurídico de "Securitização da dívida rural" brasileira, garantida pela Lei n. 9.138, que pode ser compreendida como o não pagamento das dívidas, passando pelo consumo de álcool anidro garantido pela Petrobrás, com vistas ao aumento da mistura de etanol anidro na gasolina, dos atuais $25 \%$, para $27,5 \%$, e a desoneração total do PIS/COFINS para o biocombustível, em qualquer um desses momentos o que pode ser visto é uma ampla disposição de ambas as partes (público e privada) para as negociações.

Deste modo, as diferentes crises financeiras anunciadas e vividas pela agroindústria canavieira têm origens distintas, todavia cada uma delas tem de ser colocada no eixo dessa promiscua relação público-privada.

[...] A articulação público privada da política agrária e das estratégias privadas de acumulação de capital no espaço ampliado do setor agrícola tradicional e dos complexos agroindustriais, perseguindo lucro e renda da terra, constitui aquilo que denomino novo pacto da economia política do agronegócio." (DELGADO, 2012, p. 109)

Na perspectiva teórica da expansão dos negócios agropecuários, diversos autores defensores do agronegócio brasileiro, vinculados às escolas norte americanas de administração de empresas ${ }^{9}$, tratam a agroindústria em suas pesquisas, como exemplo Neves e Conejero (2010), em termos de que este setor desenvolve-se perseguindo o lucro e a renda da terra, ainda que esta ação do capital nunca seja sumariamente citada.

\footnotetext{
${ }^{9}$ MENDONÇA, M.L.R.F. Modo Capitalista de Produção e Agricultura: A construção do conceito de Agronegócio. Tese de Doutorado, FFLCH, USP, 2013. Disponível em <http://www.teses.usp.br/ teses/disponiveis/8/8136/tde-26062013-114407/pt-br.php>. Acesso em Abr 2014.
} 
[...] Essa cadeia começa com as empresas produtoras de insumos (sementes, máquinas, fertilizantes, etc.), que suprem os produtores agrícolas (fazendeiros: café, laranja, manga, arroz, entre outros), que por sua vez vendem seus produtos, normalmente, para uma indústria processadora (basicamente de alimentos, como Cutrale, Citrosuco, Cosan, IP, Utam, etc.), que fornece o produto final para um elo distribuidor, tornando-o assim disponível ao consumidor final. [...]

[...] O Sistema Agroindustrial (SAG) da cana-de-açúcar é complexo: as usinas produtoras dependem de fornecedores de cana e de bens de capital para sua existência. Os produtos etanol, açúcar e energia são vendidos para distribuidores de combustíveis, distribuidoras de energia elétrica, indústria de alimentos, atacado e varejo e tradings exportadoras. Os subprodutos são destinados às indústrias, atacado e varejo, como a de suco de laranja e de ração animal, e as usinas aproveitam os resíduos, como vinhaça e torta de filtro, como biofertilzantes. (NEVES E CONEJERO, 2010, p. 588)

Aqui, como é possível compreender, a agroindústria é (d)escrita por outro viés do pensamento teórico, completamente distinto dos autores anteriormente citados, e acredito que não se poderia desvincular da análise nesta pesquisa a origem desta corrente, construída sob outra perspectiva que trata do mercado e do agronegócio.

A existência dessa perspectiva garante à agroindústria canavieira um especial destaque no que tange ao chamado "desenvolvimento do Brasil”, e os (agro)negócios e suas valorosas cifras que são desdobramentos desta perspectiva e colocam o etanol e o açúcar como mercadorias determinantes para o crescimento do país.

Neste particular, recorro a Chesnais para apontar esse movimento que a partir da década de 1990 se intensifica no Brasil e no mundo. A "mundialização do capital exprime a liberdade quase total do capitalismo em se desenvolver e valorizar-se". (CHESNAIS, 1997, p.8)

Assim, as questões que dizem respeito à abertura econômica ocorrida na economia brasileira com a adoção do ideário neoliberal impactaram na dinâmica do setor sucroenergético. A desregulamentação das agroindústrias canavieiras traz em seu centro os processos de concentração, centralização e internacionalização do setor. Como assinalaram Borges e Costa, neste período as agroindústrias passam a adotar ações 
ativas e reativas, a fim de ampliar a sua competitividade e destacam as seguintes ações: “de fusão e aquisição (F\&A), de modernização, de diversificação da produção, de diferenciação de produto, de diversificação geográfica, entre outras, favorecendo o processo de internacionalização, concentração e centralização do capital”. (BORGES \& COSTA, 2013)

$\mathrm{Na}$ publicação "Informe Setorial” do Banco Nacional de Desenvolvimento Econômico e Social (BNDES), publicado em 1999, o número de fusões e aquisições cresceu mais de seis vezes entre 1992 e 1997, declinando ligeiramente em 1998 (-6\%) e as indústrias de alimentos, bebida e fumo lideraram o ranking em todos os anos, respondendo por $13 \%$ do total.

Para o BNDES as razões para que o setor de alimentos e bebidas fosse o líder desse ranking, foram:

a) saturação dos mercados dos países desenvolvidos - como consumidores europeus e norte-americanos estão próximos do limite físico do consumo de alimentos, as taxas de crescimento das vendas são muito baixas levando as empresas a procurarem mercados mais dinâmicos;

b) crescente poder das cadeias de distribuição - os grandes supermercados têm reduzido as margens dos fornecedores nos países desenvolvidos, levando-os a buscar mercados menos competitivos;

c) custos crescentes - os pesados investimentos em propaganda, distribuição e qualidade tornam vitais as economias de escala, por vezes inviabilizando firmas pequenas;

d) focalização de negócios - empresas de todos os portes têm desinvestido em negócios periféricos, com o objetivo de aumentar sua eficiência, inclusive gerando caixa para fusões e aquisições em seus ramos principais; e

e) entrada em mercados regionais/locais - a compra de uma empresa já estabelecida reduz os custos de entrada em novos mercados. (BNDES, 1999, p. 02)

As fusões, aquisições e associações mostram-se como os principais instrumentos para a articulação dos capitalistas proprietários de terra e burgueses industriais. Não há perdas nesse processo, apenas ganhos e lucros e essa realidade que se tem hoje, não existiu no passado. 
Guilherme Potenza analisou diversas ações de fusão e aquisição (F\&A)

realizadas no Brasil, e salientou que:

[...] No segmento do etanol, nota-se que as companhias petrolíferas estão começando a voltar-se para as usinas. O movimento nesse setor teve inicio em 2008, com a joint venture entre BP Biofuels UK Limited, Santelisa Vale Bioenergia S.A. e Maeda S.A. Agroindustrial, para a constituição da Tropical Bioenergia S.A. Desde então, notou-se também negócios de peso envolvendo players internacionais, como a joint venture entre a Cosan S.A. Indústria e Comércio e a anglo-holandesa Shell International Petroleum Company Limited, em um negócio de US\$ 12 bilhões, além da recente joint venture entre ETH Bioenergia S.A. e Companhia Brasileira de Energia Renovável (Brenco) (uma operação relevante, apesar de contar apenas com players nacionais). Outras operações de relevo foram a aquisição da Companhia Nacional de Açúcar e Álcool pela BP Biofuels Brazil Investments Limited e as joint ventures da Petrobras Biocombustível S.A. com a Açúcar Guarani S.A. e com o Grupo São Martinho. (POTENZA, 2013, 184 p.)

Silvia Ribeiro, em artigo para o diário mexicano "La Jornada", reiterou essa interpretação:

[...] É nesta lógica capitalista que empresas e governos estão fazendo uma intensa campanha para apresentar os agrocombustíveis como alternativas para combater as mudanças climáticas, ao substituir parte do consumo de petróleo. Mas a lógica de fundo não é abandonar o petróleo nem mudar os padrões de consumo[...], mas aproveitar a conjuntura para criar novas fontes de negócios, promovendo e subsidiando a produção industrial de cultivos para estes fins. (RIBEIRO, 2007, p. 38)

A autora também apontou o fato de que todas as empresas que produzem sementes transgênicas, como Syngenta, Monsanto, Dupont, Dow, Bayer e Basf, possuem investimentos na produção de agrocombustíveis, como o etanol e o biodiesel. Pode-se ainda citar os investimentos realizados recentemente pelas empresas petroleiras, tais como: Shell, Total, BP e Petrobras, que ingressaram no setor através de fusões ou aquisições e possuem interesses específicos no mercado mundial energético.

Tudo isto é, evidentemente, uma análise que recai sobre a lógica das commodities e ao mesmo tempo reforça a condição do Brasil como um exímio exportador de mercadorias primárias e essas questões, quando contextualizadas pela ótica de Chesnais em "A mundialização do Capital", se apresentam como "certos 
momentos em que numerosos fatores desembocam num novo conjunto de relações

internacionais e internas, que 'formam um sistema' e que modelam a vida social, não

apenas no plano econômico, mas em todas as suas dimensões”. (CHESNAIS, 1996, p.

14).

Oliveira (2011) afirmou que a expansão recente do setor sucroenergético se faz

sob o signo na mundialização do capital:

[...] Mas, a relação entre o capital nacional e estrangeiro há muito tempo apresenta-se entrelaçado. O processo de mundialização deflagrado nos anos 80 e 90 do século passado soldou em outro patamar econômico e político esta relação. Veja-se, por exemplo, as fusões e associações que estão ocorrendo no agronegócio no Brasil, tornando inclusive, empresas nacionais nas maiores empresas de seus respectivos setores.

Em primeiro lugar, é preciso lembrar o que está ocorrendo no setor sucroenergético, que até a década de 90 era predominantemente ocupado por empresas de origens familiares nacionais. Com a constituição da Cosan (uma aliança entre a família Dedini e parte da família Ometto) a empresa lançou ações nas bolsas de valores nacional e internacional, comprou a Esso Mobil no Brasil e depois constituiu joint venture com a Shell, dando origem à Raízen. Ninguém comprou ninguém, apenas aliados associaram-se no mesmo negócio.

Outro exemplo neste mesmo setor ocorreu com o grupo Santelisa Vale (aliança entre a família Junqueira e Biagi) que fundiu-se com a Louis Dreyfuss Commoditties dando origem à LDC-SEV. A composição acionária da nova empresa ficou da seguinte forma: LDC com $60 \%$, acionistas da Santelisa Vale $18 \%$, bancos credores $13 \%$ e novos investidores com $9 \%$.

Há também neste setor o caso do Grupo Moema (aliança entre as famílias Biagi e Junqueira) que fundiu-se com a Bunge e terão participação de cerca de $9 \%$ das ações da empresa mundial dirigida no Brasil por Pedro Parente, ex-participante do governo FHC. Ou seja, nestes dois últimos casos as famílias Junqueira e Biagi tornaram-se sócias das multinacionais Bunge e Louis Dreyfuss, o que quer dizer aliaram-se ao capital mundial, ou, o que dá na mesma, multinacionalizaram-se.

Cabe destacar também neste setor, a presença de outros grupos mundiais associados tais como o francês Tereos do Açúcar Guarani S/A, que tem participação de 31,4\% da Petrobras Biocombustível - PBio podendo elevá-la até 49\%, nas unidades São José em Colinas/SP e Andrade em Pitangueiras/SP. (26) A PBio tem também, associação com o grupo São Martinho através da Nova Fronteira Bioenergia S/A, de 49\% na usina Boa Vista, em Quirinópolis/GO (27). Além, da associação com Cosan, Odebrecht e Copersucar, Camargo Correa e Uniduto na Lógum, empresa de logística de etanol na qual a estatal tem participação de $20 \%$. (VALOR ECONÔMICO, $12,13$ e $14 / 08 / 2011)$

Outra empresa mundial associada a capital nacional é a Archer Daniel Midland (ADM) maior produtora de etanol de milho do mundo, aliada ao exministro da agricultura Antonio Cabrera na usina Limeira do Oeste, no Triângulo Mineiro onde tem participação de $49 \%$ contra 51\% do ex-ministro. Também, entre as empresas mundiais japonesas, a Sojitz está associada à ETH Bioenergia S/A do conglomerado Odebrecht S/A; a Itochu é parceira da Bunge em duas usinas de açúcar e etanol no Brasil (20\% das usinas Santa Juliana, em Minas Gerais, e da Pedro Afonso, em Tocantins) e a aliança entre 
a Mitsui (já aliada da Vale) e a Petrobras na Usina Itarumã em Goiás (no Complexo Bioenergético a Petrobras Biocombustíveis participa com 20\% e tem como sócios a japonesa Mitsui, com 20\%, e o produtor nacional Energética do Cerrado Açúcar e Álcool Ltda, com 60\%).

Outra associação no setor foi do grupo indiano Shree Renuka Sugars, quinto maior produtor mundial de açúcar e está listado na bolsa de ações na Índia. Controla 7 usinas e 2 grandes refinarias em portos naquele país, e, desde 2010 adquiriu 4 usinas no Brasil. Entre elas estão as duas usinas adquiridas integralmente do grupo Vale do Ivaí no norte do Paraná, localizadas nos municípios de São Pedro do Ivaí e São Miguel do Cambuí, e participações em infraestrutura logística: dois terminais portuários - um de açúcar, a Pasa (Paraná Operações Portuárias), com 12,7\%, e o de álcool, Álcool do Paraná, com 9,08\%, e $8 \%$ na CPA Trading. Nas duas outras unidades, o grupo indiano comprou $50,34 \%$ das ações da unidade do Grupo Equipav controlado pelas famílias Toledo, Vetorazzo e Tarallo, que ficaram com os outros 49,66\%. A indiana Shree Renuka Sugars e o grupo Olam International, de Cingapura, também, constituíram uma parceria no Brasil para realizar investimentos em açúcar e etanol. A parceria não envolve as unidades já controladas pelos indianos, mas sim, as futuras aquisições que serão feitas pelos dois grupos.

O setor sucroenergético tem também, a participação do grupo de Hong Kong, Noble Group, que adquiriu da família Fernandes do grupo Cerradinho as duas usinas localizadas nos municípios de Catanduva e Potirendaba em São Paulo. Enquanto que a usina Porto das Águas, no município de Chapadão do Céu, em Goiás, continuará sob o controle da família Fernandes. Já as terras onde estão as plantações de cana que abastecem as usinas de São Paulo também continuaram como propriedade da família.

A trading suíça Glencore também associou-se à família Garieri passando a controlar 70\% da usina de etanol Rio Vermelho, de Junqueirópolis/SP. A Adecoagro S/A que tem entre seus sócios o bilionário George Soros adquiriu a Angélica Agroenergia S/A localizada em Angélica no Mato Grosso do Sul e Usina Monte Alegre no sul de Minas Gerais." (OLIVEIRA, 2011, p. 82)

Certamente, o processo de mundialização do capital, trouxe consigo no Brasil,

outras inovações: a abertura do capital desses monopólios nas Bolsas de Valores:

[...] Entre outros exemplos da aliança de classe de setores da burguesia brasileira com a mundial, estão as novas empresas nacionais que começaram a nascer a partir de 2005, no setor sucroalcooleiro e de celulose, e, na atualidade, principalmente no setor de grãos, que estão abrindo seus capitais em bolsas de valores, ou seja, fazendo seus IPOs (Initial Public Offering Oferta Pública Inicial de ações em Bolsas). Essas novas empresas seguem o caminho aberto pela Cosan que foi a primeira de seu setor a abrir seu capital em bolsa no ano de 2005 .

Essas novas empresas de capital aberto, no campo brasileiro estão juntando de forma articulada na aliança de classe com o capital mundial, o rentismo típico do capitalismo no Brasil, e, assim, estão fazendo simultaneamente, a produção do capital via apropriação da renda capitalizada da terra e a reprodução ampliada do capital acrescida do lucro extraordinário representado pelas diferentes formas da renda da terra. Ou seja, passam a atuar no mercado de terras, no preparo da propriedade para produção, na produção em si e na comercialização. E mais, esses grupos interessados em terras brasileiras têm se associado a investidores e fundos, e alguns já abriram seu capital, outros estão se preparando para tal. Além do fato em si de que a negociação de terras passou a chamar a atenção do setor financeiro, a emissão de ações deu opções para os fundos, permitindo assim, que estrangeiros 
participem desse mercado, independentemente das ações do governo, quanto às eventuais restrições às aquisições terras por estrangeiros. (OLIVEIRA, 2010, p. 84)

No Estado de São Paulo, o qual se apresenta como o maior produtor nacional de culturas que possuem elevado valor de produção, como a cana-de-açúcar e a laranja, estas alianças de classe com o capital mundial são resultados de novas alianças interclasse burguesa mundial. Como consequência alteram-se as lógicas de superexploração na relação capital-trabalho que no caso específico do setor sucroenergético se dá por meio da produção da cana-de-açúcar e sua consequente e vigorosa possibilidade de acumulação, seja pela apreensão da mais-valia dos trabalhadores, seja pelos juros que são gerados pelos rendimentos advindos desta produção seja pela apropriação da renda da terra. Ou seja, é sempre a acumulação, o objetivo principal tanto dos capitalistas quanto dos proprietários de terra.

E neste sentido, frente às investidas de Estado nesta relação, é possível afirmar que a política neoliberal não saiu do processo de crescimento/desenvolvimento do setor, ou seja, mesmo com a desregulamentação e a abertura econômica do país, o Estado brasileiro seguiu cumprindo um determinante papel para alavancar a produção da agroindústria canavieira, longe de ser mínimo, o Estado configura-se como máximo aliado dos usineiros e latifundiários no Brasil.

Portanto para se compreender estes processos de desenvolvimento do modo capitalista de produção no campo brasileiro, nas últimas décadas, é preciso descortinar esse ideário liberal, marcado pela subordinação do governo brasileiro ao capital financeiro internacional.

Para se aprofundar este debate, colocando luz no setor sucroenergético, é importante salientar que a Companhia Nacional de Abastecimento (Conab) informou 
em seus estudos de perspectivas para a agropecuária que a previsão para a safra de 2014/2015 de cana-de-açúcar, baseada na área da safra atual acrescida do incremento da expansão, estará em torno de 694 milhões de toneladas. A projeção para a produção de açúcar estará em torno de 43,5 milhões de toneladas e para a produção de etanol aproximadamente 28,9 bilhões de litros (sendo 12,8 bilhões de litros anidro e 16,1 bilhões de litros hidratado). A União da Indústria de Cana-de-Açúcar (UNICA) por sua vez, indicou o Brasil como o maior produtor de cana-de-açúcar do mundo e também o $1^{\circ}$ produtor mundial de açúcar, responsável por $25 \%$ da produção mundial e $50 \%$ das exportações mundiais, e o $2^{\circ}$ produtor mundial de etanol, sendo responsável por $20 \%$ da produção mundial e $20 \%$ das exportações mundiais.

[...] A produção de cana-de-açúcar deve apresentar expansão em todos os estados considerados. As maiores expansões de produção devem ocorrer em Goiás, 81,8\%; Minas Gerais, 61,2\% e Mato Grosso, 27,8\%. Nesses estados a cana deve se expandir através da redução de área de outras lavouras e também em áreas de pastagens. São Paulo, líder da produção nacional, deve ter um aumento de produção de cerca de $41,2 \%$ na próxima década. Finalmente, as projeções regionais estão indicando que os maiores aumentos de produção, da cana-de-açúcar, devem ocorrer no Estado de Goiás, embora este ainda seja um estado de produção pequena. Mas São Paulo como maior produtor nacional, também, projeta expansões elevadas de produção desse produto. ” (MAPA, 2012.)

Questões quantitativas lançam objetivamente aos olhos mais atentos que a evolução da agroindústria canavieira no Brasil está garantida. Evolução esta que se dá de uma maneira particular e aponta para as relações e mediações do mercado internacional e mercado nacional dentro da indústria do açúcar e do álcool.

Assim, torna-se mister assinalar que o núcleo central das discussões desenvolvidas nessa pesquisa estão voltadas justamente para estas contradições próprias do desenvolvimento capitalista e, especialmente para a análise das relações entre a agricultura capitalista e a indústria canavieira. Isto implica necessariamente na 
compreensão das formas de apropriação da renda da terra pelo capital e na noção de exploração da força de trabalho neste setor.

Para tanto, esta investigação volta-se nesse momento para a análise do grau de concentração da produção canavieira e ao mesmo tempo, para a elucidação de como este fenômeno econômico pode ser lido pela geografia na lógica do processo de construção/reconstrução do território. 


\section{II - O processo de territorialização dos monopólios no setor sucroenergético.}

Para pensar o campo no âmbito da tradição marxista, precisa-se de imediato assumir, a partir da leitura de Kautsky (1986), o entendimento de que o capital também pode se reproduzir no campo, não atuando como produtor específico das mercadorias, mas como o controlador da especulação das mercadorias. Ou seja, a produção, distribuição, circulação e consumo que são distintos momentos do processo econômico possibilitam a acumulação do capital por parte dos capitalistas e/ou proprietários de terra.

Nesse sentido, é preciso retomar o pensamento marxista dialético para entender a condição que a propriedade da terra tem de ser monopolizável e, ao mesmo tempo, elucidar a produção de mercadorias, bem como a produção de mais valia, "numa contradição dialética do movimento de acumulação capitalista" (LUXEMBURG, 1985, p. 251), sendo esta condição determinante para a realização desse processo econômico que se desenvolve no campo brasileiro.

A "relação entre produção, distribuição, troca (circulação) e consumo, como constitutivos de uma unidade dentro da totalidade da estrutura de produção" é o movimento que permite a leitura e compreensão da realidade e deste modo, a apreensão do processo de territorialização do monopólio no setor sucroenergético. E este movimento se dá desde o processo produtivo no campo, passando pelo processamento industrial da produção agropecuária até o controle da propriedade privada da terra.

[...] o modo capitalista de produção não está a circunscrito apenas e tão somente à produção, mas também à circulação de mercadorias, da troca de mercadorias por dinheiro e de dinheiro por mercadorias. Isso decorre 
do fato de que o modo capitalista de produção não é na essência um modo de produção de mercadorias no seu sentido restrito, mas sim modo de produção de mais-valia. Além disso, devemos ter claro que o produto final do processo de produção não é a mais-valia e sim a mercadoria. Esta contém a mais-valia, que não se confunde com o produto final do processo de produção, ou em outras palavras, a mais- valia está prisioneira à mercadoria, e a sua realização se dá com a circulação, quando o movimento de rotação do capital se completa (D - M - D'). É no momento da produção que a mais-valia é gerada pelo trabalho (das classes trabalhadoras), ou seja, é produzida; porém é no momento da circulação que a mais-valia é realizada.

É a partir dessa realização que se pode dar a distribuição dos frutos da produção, distribuindo a parte correspondente à remuneração do trabalho executado pelos trabalhadores e contido na mercadoria; o pagamento das matérias-primas e auxiliares e aquele correspondente ao desgaste dos meios de produção utilizados no processo de produção; e por a fatia referente à mais-valia, que é produto da exploração do capital sobre trabalhador. (OLIVEIRA, 2010, p. 5/6)

Para Oliveira (1998) é fundamental advertir que esse processo de expansão do capitalismo monopolista no Brasil vem determinando a estrutura agrária do país e no caso da industrialização da agricultura, o capitalista se tornou também proprietário de terras. Assim, "capitalista industrial, proprietário de terras e capitalista da agricultura têm um só nome, são uma só pessoa ou uma mesma empresa”. Um exemplo claro para o autor no que se refere a este processo são as usinas ou destilarias de açúcar e álcool, onde atualmente indústria e agricultura são parte ou etapas de um mesmo processo" (OLIVEIRA, 1998, p. 478).

Neste sentido, é bom frisar que no caso do setor sucroenergético, como ressaltou Oliveira (1983) "o capital tem sabido implantar-se de forma monopolista nesse setor" e mais, "sem dúvida alguma a agroindústria açucareira, representa hoje o exemplo mais significativo do processo de monopólio na produção com consequente subordinação da circulação aos desígnios da produção” (OLIVEIRA 1983, p. 20/21)

Martins antecipava esse debate ao analisar em sua obra "O cativeiro da terra" a origem da propriedade privada em nosso país, associada ao processo de acumulação de capital e exploração do trabalho livre: 
[...] A primeira etapa da expansão do capitalismo é a produção de mercadorias, e não necessariamente a produção de relações de produção capitalistas. O processo que institui e define a formação econômico-social capitalista é constituída de diferentes e contraditórios momentos articulados entre si: num deles temos a produção da mercadoria e da mais-valia organizados de um modo caracteristicamente capitalista, dominado pela mais-valia relativa; num outro temos a circulação da mercadoria, subordinada à produção; num outro temos a produção subordinada à circulação. Mas esses momentos estão articulados entre si num único processo, embora possam estar disseminados por espaços diferentes. Estou, portanto, trabalhando com a premissa de que a mercadoria dá um caráter mundial ao capitalismo. Ao mesmo tempo, o meu intuito é o de ir além de procedimentos mecanicistas que do plano teórico para o plano empírico da realidade histórica as etapas da transformação social. Marx assinalou, em mais de uma ocasião, a questão do ritmo das transformações históricas com o advento do capitalismo, indicando que as relações capitalistas de produção, uma vez instauradas, se disseminam pouco a pouco, de forma até imperceptível, como se nenhuma transformação estivesse ocorrendo (MARTINS, 2010, p. 37)

Contraditoriamente, ocorre o processo de sujeição da renda da terra ao capital

nos setores de produção não-capitalista, terras de trabalho camponês - produtores de alimentos (milho, feijão, trigo, mandioca e arroz). Neste caso Oliveira (1983) observou que

[...] O processo de produção de relações não-capitalistas de produção como recurso para garantir a sua própria expansão, tem-se dado, no caso brasileiro, inicialmente pela intensificação das relações comerciais, que tem, através da circulação da mercadoria de origem agrícola toda a renda diferencial para este setor, onde graça toda a sorte de representantes do capital comercial, também conhecidos como intermediários, atravessadores, atacadista, etc. Mas o processo não se restringe aí. $\mathrm{O}$ Estado se incumbe de mediar esse processo e acelerá-lo. Agindo pois, através do crédito bancário (oficial), cria os limites da dependência do produtor (do pequeno principalmente), mantendo-o permanentemente endividado. No final do processo, drena através de juros cobrados pelos empréstimos parte da renda da terra, mesmo no caso de não ser o proprietário dela. A outra parte da renda da terra é extraída pelos componentes do capital comercial, que tem atuado no sentido de impor preços abaixo do valor ao produtor, ficando assim com parcela cada vez maior da renda da terra e da parte que seria creditada, como lucro médio que nesse caso não regula a produção, pois a terra do pequeno produtor é terra de trabalho, e não empregada como instrumento de exploração da força de trabalho de outrem (assalariado). (OLIVEIRA, A. U. 1983, p. 9/10)

Acrescenta-se ainda as colocações de José de Souza Martins, no que tange a questão agrária e que dizem respeito às formas de apropriação da renda da terra pelo capital: 
[...] A propriedade familiar não é propriedade de quem explora o trabalho de outrem; é propriedade direta de instrumentos de trabalho por parte de quem trabalha. Não é propriedade capitalista; é propriedade do trabalhador. Seus resultados sociais são completamente distintos, porque nesse caso a produção e a reprodução das condições de vida dos trabalhadores não são reguladas pela necessidade de lucro do capital, porque não se trata de capital no sentido capitalista da palavra. O trabalhador e lavrador não recebem lucro Os seus ganhos são ganhos do seu trabalho e do trabalho da sua família e não ganhos do de capital, exatamente porque esses ganhos não provêm da exploração de um capitalista sobre um trabalho expropriado dos instrumentos de trabalho. Apenas quando o capital subordina o pequeno lavrador, controlando os mecanismos de financiamento e comercialização, processo muito claro no Sul e no Nordeste é que sub-repticiamente as condições de existência do lavrador e de sua família, suas necessidades e possibilidades econômicas e sociais começam a ser reguladas e controladas pelo capital, como se o próprio lavrador não fosse o proprietário da terra, como se fosse um assalariado capitalista. (MARTINS, J.S. 1982: 59/60)

Ou seja, para Martins “a terra é um bem natural, não pressupõe trabalho em sua continuação, razão pela qual é um equivalente de capital, apesar de facultar a extração direta da mais valia, desde que submetida às regras da exploração capitalista, na qual a propriedade/ gestão está separada do trabalho."

Então, apropriação e acumulação ganham evidência empírica por meio da obtenção da renda da terra nas suas diferentes formas (absoluta, diferencial e de monopólio) (OLIVEIRA, 1984, 1985 e 1986).

Como Karl Marx afirmou "o apropriar-se da renda é a forma econômica em que se realiza a propriedade fundiária, e a renda fundiária supõe propriedade fundiária, que determinados individuos sejam proprietários de determinadas parcelas do globo terrestre. " (Marx, 1974, p. 727)

Toda essa questão se faz imprescindível para o debate da territorialização do setor sucroenergético. E, a esse respeito, cabe salientar algumas colocações de Thomaz Jr. sobre a expansão das lavouras canavieiras no Estado de São Paulo. Para o autor, “essas transformações ocorridas na agricultura via 'modernização' bem como apropriação da renda da terra, são o 'baluarte' do processo de territorialização do 
monopólio capitalizado pelas empresas sucroalcooleiras do estado, o que tomará expressão mais significativa a partir da segunda metade da década de 1970." (THOMAZ, JR. 1988: 86)

Observa-se assim que o processo de territorialização do monopólio na ótica de Thomaz Jr é evidenciado por meio da apropriação crescente da renda fundiária pelos grupos usineiros, estes que tem o controle do processo produtivo e consequentemente de determinação do preço da cana. O autor continuou, afirmando que "este processo se desenrola não uniformemente, mas sim de forma diferenciada, porque não necessariamente os grupos usineiros compram terras. Utilizam em alguns casos a prática do arrendamento. [...] Assim, passa-se a ter uma nova configuração do território. ” (THOMAZ, JR. 1988: 99/112)

Para Oliveira (2007), o centro fundante do conceito de território é o poder e a possibilidade de seu exercício sobre uma fração do mundo. O poder de ser e estar em um ponto ou outro desta fração do mundo, monopolizando-a. Esta existência (ser/estar) das práticas sócio-territoriais é determinante para a materialização de diferentes formas de apropriação existentes no mundo. Um processo eminentemente sócio-histórico. Em vista disso, de acordo com o autor, é que se parte, portanto, da concepção (OLIVEIRA, 1999) de que o território deve ser apreendido como síntese contraditória, como totalidade concreta (modo de produção/distribuição/circulação/consumo) e suas articulações e mediações supraestruturais (políticas, ideológicas, simbólicas, etc.). Processos onde o Estado, no atual estágio de desenvolvimento do capitalismo, desempenha a função de regulação desse efetivo exercício.

Mas de qual Estado regulador se faz referência? A dimensão de classe sintetiza esta perspectiva e trabalha-se aqui a compreensão burguesa de Estado expressa nas 
análises de Engels e Marx em "Origem da Propriedade Privada e do Estado" (1981), e XVIII Brumário (1969), ou Crítica ao Programa de Gotha (1965).

Oliveira (2008) indicou que "o território é assim, produto concreto da luta de classes travada pela sociedade no processo de produção de sua existência. Dessa forma, são as relações sociais de produção e o processo contínuo/contraditório de desenvolvimento das forças produtivas que dão a configuração histórica específica ao território". (OLIVEIRA, 2008, p. 5). E de acordo com o autor:

[...] Nesta perspectiva também é ressaltada a contradição e luta entre as classes sociais no processo de construção dos territórios. Concebendo que o território é, assim, efeito material da luta de classes travada pela sociedade na produção de sua existência. Sociedade capitalista que está assentada em três classes sociais fundamentais: proletariado, burguesia e proprietários de terra. "(OLIVEIRA, 2004 p.40)

Partindo dessas premissas e concordando com Raffestin (1993 p.143) que afirmou que:

[...] O território se forma a partir do espaço, é resultado de uma ação conduzida por um ator sintagmático (ator que realiza um programa) em qualquer nível", ao mesmo tempo em que "o território é um trunfo particular, recurso e entrave, continente e conteúdo, tudo ao mesmo tempo. O território é o espaço político por excelência, o campo da ação dos trunfos. (RAFFESTIN, 1993 p.59/60

Neste particular, Raffestin foi claro: "o território é um espaço onde se projetou um trabalho, seja energia e informação, e que, por consequência, revela relações marcadas pelo poder" (RAFFESTIN, 1993: 143/4).

Exatamente por isso insiste-se nessa pesquisa em uma discussão sobre as alterações territoriais significativas que advém desta expansão da agroindústria canavieira, particularmente, das grandes safras de cana-de-açúcar para a produção do açúcar e do álcool, no Estado de São Paulo. 
Neste sentido, reafirma-se que este processo de materialização das relações de produção capitalista no campo é caracterizado de um lado a unificação do proprietário da terra, do capitalista agrícola e do capital industrial é a mesma pessoa física ou jurídica, e de outro lado, o processo de sujeição da renda da terra ao capital nos setores de produção não capitalistas: terras de trabalho camponês (THOMAZ, JR, 1988: 85)

Dito isto, torna-se fundamental desvendar estes processos contraditórios e diversos do capital, na sua fase monopolística de reprodução ampliada e neste sentido garantir a possibilidade de dar mais um passo no caminho do fortalecimento de uma teoria do território para entender-se a realidade do campo paulista.

Na ótica da geografia, submetendo a teoria à realidade, revelando as recentes transformações do campo paulista que passam fundamentalmente pelos processos de monopolização do território e territorialização do monopólio, processos contraditórios e distintos, retomo Oliveira que afirmou que:

[...] De um lado está a territorialização dos monopólios que atuam simultaneamente, no controle da propriedade privada da terra, do processo produtivo no campo e do processamento industrial da produção agropecuária, o exemplo é o setor sucroenergético e o setor de produção de celulose. Neste caso de fato a produção comanda a circulação das mercadorias. De outro lado, está a monopolização do território desenvolvido pelas empresas de comercialização e/ou processamento industrial da produção agropecuária, que sem produzir absolutamente nada no campo, controla através de mecanismos de sujeição, camponeses e capitalistas produtores do campo. Estas empresas monopolistas do setor de grãos atuam como players no mercado futuro das bolsas de mercadorias do mundo, e, muitas vezes têm também, o controle igualmente monopolista da produção dos agrotóxicos e dos fertilizantes. Neste caso a circulação comanda a produção e dita o consumo. Este processo atua e subordinando a produção capitalista e camponesa dos setores dos grãos, carne bovina, aves, suínos, café, suco concentrado de laranja, tabaco e os alimentos para o mercado interno tais como arroz, feijão, milho, trigo, mandioca, frutas, hortícolas, etc" (OLIVEIRA, 2009, p. 7). 
No caso da territorialização do setor sucroenergético o capital instala-se na agricultura e controla totalmente a propriedade, sem deixar alternativas aos camponeses que trabalham a terra e não fazem dela um negócio.

Segundo Oliveira,

[...] As transformações recentes relativas ao setor sucroalcooleiro no Brasil têm a ver com os processos em desenvolvimento referentes aos agrocombustíveis.

[...]. Portanto, o açúcar é o regulador mundial do setor sucroenergético, e não o álcool como muitos imaginam. O plantio de cana-de-açúcar para a produção de álcool ocorre de forma intensa e significativa, apenas no Brasil. Assim, cabe deixar claramente explicitado que o etanol não é uma commodity internacional. Têm ocorrido tentativas por parte do Brasil, para procurar transformar este produto em mercadoria internacional, mas, ele ainda não o é. Dessa forma, o etanol de cana-de-açúcar tem se tornado um combustível importante apenas no Brasil. Este fato está relacionado historicamente com as políticas públicas voltadas para o setor. Entre elas cabe destacar o desenvolvimento de tecnologia para produção do motor movido a álcool e mais recentemente ao motor flex. (OLIVEIRA, 2009, p. 11).

Como consequência desse estímulo das políticas públicas para o crescimento do setor, como apresentado anteriormente, de acordo com os dados da União da Indústria de Cana-de-Açúcar (UNICA), registrou-se um aumento significativo na produção de cana-de-açúcar, açúcar e álcool anidro e hidratado, no Estado de São Paulo. Lembrando que esse avanço se dando tanto em terras tomadas em arrendamento ou parceria, como em terras de propriedade de usinas e destilarias, por vezes ocupadas ilegalmente.

Neste sentido, é bom frisar que no caso do setor sucroenergético, como ressaltou Oliveira (1983) "o capital tem sabido implantar-se de forma monopolista nesse setor" e mais, "sem dúvida alguma a agroindústria açucareira, representa hoje o exemplo mais significativo do processo de monopólio na produção com consequente subordinação da circulação aos desígnios da produção" (OLIVEIRA, 1983, p. 20/21). 
[...] A territorialização dos monopólios atua simultaneamente, no controle da propriedade privada da terra, do processo produtivo no campo e do processamento industrial da produção agropecuária. Esse processo deriva da especificidade de dois setores: o sucroenergético e o de celulose e madeira plantada. Deriva também, da relação entre o capital nacional e estrangeiro que, há muito tempo, apresentam-se entrelaçados. O processo de mundialização soldou em um outro patamar econômico e político esta relação. Veja-se, por exemplo, as fusões e associações que estão ocorrendo no agronegócio no Brasil, tornando inclusive, empresas nacionais nas maiores empresas mundiais de seus respectivos setores.

[...] O setor sucroenergético até a década de 90 era predominantemente ocupado por empresas de origens familiares nacionais. Com a constituição da Cosan (uma aliança entre a família Dedini e parte da família Ometto) a empresa lançou ações nas bolsas de valores nacional e internacional, comprou a Esso Mobil no Brasil e depois constituiu joint venture com a Shell, dando origem à Raízen. Ninguém comprou ninguém, apenas aliados associaram-se no mesmo negócio. (OLIVEIRA, 2012, p. 8).

Neste percurso teórico, a respeito da transformação da terra em mercadoria,

Martins (1986, p. 32-33) foi enfático,

[...] A terra transformada em mercadoria tem efeitos bem diferentes das outras mercadorias que se caracterizam por serem produtos do trabalho humano. A terra é uma mercadoria completamente distinta das demais. A diferença está em que a terra não é produto do trabalho, é finita e imóvel. É uma mercadoria que não circula; em seu lugar circula o seu representante, o título de propriedade. $\mathrm{O}$ que se compra e vende não é a própria coisa, mas o seu símbolo. Todas as verdadeiras mercadorias se realizam na sua utilidade e na sua utilização; elas se realizam nas mãos de quem as possui e usa. A terra não é propriamente mercadoria, mas equivalente de mercadoria. Para que possa produzir renda - que é o seu uso capitalista - a terra não exige que o ter e o usar estejam juntos. Nas outras mercadorias, o ter é condição do usar e o usar é a realização do ter; no caso da terra, na sociedade capitalista (e é dela que estamos falando), não é necessário que estejam juntos. (MARTINS, 1986, p. 32/33)

Ainda de acordo com Martins (1980, p. 60/61),

[...] Quando o capitalista se apropria da terra, ele o faz com o intuito do lucro, direto ou indireto". Ou a terra serve para explorar o trabalho de quem não tem terra; ou a terra serve para ser vendida por alto preço a quem dela precisa para trabalhar e não a tem. Por isso, nem sempre a apropriação da terra pelo capital se deve à vontade do capitalista de se dedicar à agricultura. $\mathrm{O}$ monopólio de classe sobre a terra assegura ao capitalista o direito de cobrar da sociedade inteira um tributo pelo uso da terra. É a chamada renda fundiária ou renda da terra. A renda não existe apenas quando a terra é alugada; ela existe também quando a terra é vendida. Alugar ou vender significa cobrar uma renda para que a terra seja utilizada.

[...] A terra é completamente diferente dos outros meios de produção. 
A princípio, de todas as questões relacionadas à agroindústria canavieira, devese ressaltar que a formação e concentração territorial e o uso monopolista deste território pelo setor sucroenergético passa pela apropriação privada das terras e a quantidade de riqueza apropriada por aqueles que se apossaram privadamente da terra.

[...] O território não é um prius ou um a priori, mas a contínua luta das classes sociais pela socialização igualmente contínua da natureza é, pois, simultaneamente, construção, destruição, manutenção, e transformação. É em síntese, a unidade dialética, portanto contraditória, da espacialidade que a sociedade tem e desenvolve de forma desigual, simultânea e combinada, no interior do processo de valorização, produção e reprodução. " (OLIVEIRA, 1999, p. 12)

[...] O território, por sua vez, é um espaço transformado pelo trabalho, é, portanto uma produção humana, logo espaço de luta, de luta de classes ou frações de classes. Por causa de todas as ralações que envolvem, inscreve-se no campo do poder, sendo, pois o lugar da luta cotidiana da sociedade pelo seu devir." (OLIVEIRA, 1999, p. 13)

Corroborando com esta perspectiva prático-teórica, Thomaz Jr (1988) analisando as relações de produção que formavam a estrutura econômica da sociedade assumiu que:

[...] O processo de materialização das relações de produção capitalista no campo, via internacionalização do modo de produção capitalista, dá-se de forma contraditória e a apropriação da renda da terra pelo capital tem, por um lado, a unificação do proprietário e do capitalista numa mesma pessoa - é o que acontece com a cana-de-açúcar em São Paulo - e de outro, o processo de sujeição da renda da terra ao capital nos setores de produção não capitalistas; por exemplo, na propriedade familiar de tipo camponês."

[...] A instrumentalização do processo de territorialização do monopólio, que se entendido no plano teórico, como sendo a expansão das relações capitalistas de trabalho e de produção na agricultura, fica mais evidente que a cana-de-açúcar, na região (e num contexto mais representativo, o Estado de São Paulo), se "especializa" dando uma feição toda particular ao território, ou seja, territorializa-se monopolizando o espaço. " (THOMAZ JR, 1988, p.84/85)

A indústria da cana, o complexo canavieiro, ou o setor sucroenergético, todos nomes dados para a agroindústria canavieira, quando analisados de forma materialista dialética, mostrando suas contradições, revelam que a territorialização provocada pelos grupos produtores de cana-de-açúcar, se utilizam de várias possibilidades para produzir 
mais e acumular mais capital na agricultura. Seja por meio do monopólio sobre a propriedade privada da terra (vias legais e ilegais); seja pela apropriação da mais-valia dos trabalhadores (incluindo a prática da peonagem, conhecida como trabalho análogo à escravidão); seja pela apropriação da renda da terra em todas as suas formas. Todos esses processos conferem aos proprietários de terra e/ou capitalistas a acumulação e concentração de terra e capital.

Ressalta-se nesse momento que na medida em que se busca analisar o setor sucroenergético em sua direta relação com o processo produtivo agrícola e industrial, é importante frisar que feita uma opção clara por trabalhar nesta pesquisa com a dialética materialista, as contradições da realidade e a conjuntura atual, as quais preenchem os debates teóricos, possibilitam também algum tipo de ação direta na luta política vivenciada cotidianamente ${ }^{10}$.

Neste sentido, assumindo as relações entre poder e território apontadas por Raffestin $^{11}$, a busca do significado propriamente geográfico do processo de territorialização do monopólio no setor sucroenergético, guia esta pesquisa em seus diferentes momentos, teórico e/ou prático.

\footnotetext{
10 "Na produção social da própria vida, os homens contra em relações determinadas, necessárias e independentes de sua vontade, relações de produção estas que correspondem a uma etapa determinada de desenvolvimento das suas forças produtivas materiais. A totalidade destas relações de produção forma a estrutura econômica da sociedade, a base real sobre a qual se levanta uma superestrutura jurídica e política, e à qual correspondem formas sociais determinadas de consciência. $\mathrm{O}$ modo de produção da vida material condiciona o processo em geral da vida social, político e espiritual. Não é a consciência dos homens que determina o seu ser, mas, ao contrário, é o seu ser social que determina a sua consciência ... Assim, como não se julga o que um indivíduo é a partir do julgamento que ele faz de si mesmo, da mesma maneira não se pode julgar uma época de transformação a partir de sua própria consciência; ao contrário, é preciso explicar esta consciência a partir das contradições da vida material, a partir do conflito existente entre as forças produtivas sociais e as relações de produção".Karl MARX, "Introdução para a Crítica da Economia Política"- Coleção Os Pensadores, Abril Cultural, São Paulo, 1974, p.135/6.

${ }^{11}$ Para Raffestin o conceito território implica não apenas em uma dimensão espacial, mas pressupõe a existência de relações de poder (RAFFESTIN, 1993)
} 
Claude Raffestin (1993), ao tratar do território e da territorialidade, levantou a questão do poder presente no território. Assim, para ele,

[...] os homens "vivem", ao mesmo tempo, o processo territorial e o produto territorial por intermédio de um sistema de relações existenciais e/ou produtivistas. Quer se trate de relações existenciais ou produtivistas, todas são relações de poder, visto que há interação entre os atores que procuram modificar tanto as relações com a natureza como as relações sociais. Os atores sem se darem conta disso, se automodificam também. O poder é inevitável e, de modo algum, inocente. Enfim, é impossível manter uma relação que não seja marcada por ele' (RAFFESTIN, 1993, p.99).

[...] Não fazer a distinção entre o espaço e o território é como não fazer a diferença entre o mineral de ferro e uma ferramenta feita pelo homem. Entre os dois se intercalam numerosas etapas e numerosos processos que fazem as culturas intervirem no sentido antropológico do termo. Eu considerei o espaço, de forma axiomática, como aquilo que era dado e o território como o que era produzido, a partir do espaço, pela ação humana, o que restitui todo seu valor ao trabalho (energia informada) e à cultura como programa complexo próprio a cada sociedade. (RAFFESTIN, 2008)

Destacam-se as profundas relações que a formação da propriedade privada da terra capitalista no Brasil tem, e, precisam ser elucidados por meio da ciência geográfica, a fim de buscar a compreensão dos processos desenvolvimento do modo capitalista de produção em nível mundial. Raffestin apontou que "não se pode mais definir a geografia como o estudo do espaço geográfico que é, naturalmente, uma tautologia. Geografia para o autor é explicitar o conhecimento e a prática que os homens têm na realidade material que é a Terra. O objeto da geografia é relacional e não material." 12

Do mesmo modo, desenvolveram-se os estudos da agricultura brasileira, que de acordo com Oliveira (2007):

[...] deve ser feito levando-se em conta que o processo de desenvolvimento do modo capitalista de produção no território brasileiro é contraditório e

\footnotetext{
12 [...] Il est parfaitement évident que la méthodologie relationnelle est fondamentale et encore plus dans le contexte actuel pour la bonne et simpleraison que l'on ne peut plus définir la géographie comme l'étude de l'espace géographique qui est naturellement une tautologie. La géographie est l'explicitation de la connaissance et de la pratique que leshomme sont de la réalité matérielle qu'est la Terre. L'objet de la géographie est relationnel et non pas matériel! (RAFFESTIN, 2012, p. 176)
} 
combinado. Isto quer dizer que, ao mesmo tempo em que este desenvolvimento avança reproduzindo relações especificamente capitalistas (implantando o trabalho assalariado através da presença no campo do "boiafria"), ele (o capitalismo) produz também, igual e contraditoriamente, relações camponesas de produção (através da presença e do aumento do trabalho familiar no campo). (OLIVEIRA, 2007, p. 32)

Reforço, assim, por fim que, a inserção dessa perspectiva colocou para este trabalho os eixos que lhe dão sustentação, partindo da produção capitalista do setor sucroenergético, passando pelas estratégias dos grandes grupos monopolistas até chegar ao debate do controle e divisão do território. 


\section{III - A marcha da acumulação, concentração e centralização do capital}

\section{e o setor sucroenergético.}

O capital necessita estabelecer-se em toda parte, explorar em toda parte, criar vínculos em toda parte. (Marx \& Engels, 1982, p. 97).

A partir dos dados da atual economia do agronegócio, buscou-se nesse capitulo elucidar os processos de concentração e centralização do capital no setor sucroenergético.

$\mathrm{Na}$ atualidade, o setor sucroenergético organiza-se a partir da lógica econômica do capitalismo monopolista mundializado, a qual encontra, no caso brasileiro, a produção de commodities e a circulação nas bolsas de Mercadorias e de Futuro seus centros fundantes.

Como alertou Delgado (2012):

[...] No final dos anos 1990, passada a inviável experiência do primeiro governo FHC - de acumulação de déficits externos crescentes e contínuos -, o Brasil virou a "bola da vez" da especulação financeira internacional em 1999 (crise cambial), o que forçaria o segundo mandato de Fernando Henrique a reorganizar sua política econômica externa, tendo em vista gerar saldos comerciais de divisas a qualquer custo. Nesse momento começou a reestruturação econômica da economia do agronegócio, diretamente vinculada à expansão mundial das commodities. Em pouco mais de uma década (1999-2012), o país quintuplicou suas exportações em dólares passando de US\$ 50 bilhões a US\$ 250 bilhões. Nesse boom exportador, os produtos primários - básicos e semi-elaborados - ganharam protagonismo, enquanto as manufaturas foram saindo das exportações e ingressando paulatinamente nas importações (entre os anos 1995-1999 e 2008-2010, os produtos primários pularam de $44 \%$ para $54,3 \%$ da pauta exportadora, enquanto os manufaturados decresceram proporcionalmente).

O processo de reestruturação econômica é notório, não necessitando maiores detalhes. Menos conhecido é o papel do Estado pelo lado do SNCR (fortemente expansivo) e pela política fundiária (completamente desregulada), que deram pela via estatal o beneplácito à acumulação e à especulação fundiária. (DELGADO, 2012, p. 111) 
De acordo com os dados apresentados por Borges (2012) o Brasil exibe hoje um quadro de 426 agroindústrias canavieiras, sendo 249 de produção mista, ou seja, produzem tanto açúcar quanto álcool, a depender fundamentalmente do mercado para tomar essa decisão, 161 agroindústrias exclusivamente produtoras de álcool e 16 unicamente dedicadas a produção de açúcar. Sobre a relação do Estado com o setor, no Estado de São Paulo, ainda de acordo com a autora, podem-se verificar os mais altos valores de desembolsos setoriais do BNDES (\%). São Paulo é, sem dúvida, o Estado de maior representatividade no setor e conta com um total de 197 agroindústrias, sendo 130 agroindústrias de produção mista, 61 exclusivamente produtoras de álcool e 06 que produzem unicamente o açúcar.

No caso do BNDES, ainda de acordo com Borges (2012), os desembolsos são para 19 finalidades, sendo: aquisição e recuperação de máquinas agrícolas; capital de giro; capitalização institucional financeira; cartão BNDES; desenvolvimento de mercado de capitais; desenvolvimento social; desenvolvimento tecnológico; expansão; financiamento de compra de maquis/serviços; implantação; meio ambiente; modernização; pós-embarque; pré-embarque; racionalização; reestruturação social; refinanciamento; re-localização; social corporativo.

A autora revelou que o Estado de São Paulo é o Estado que apresenta a maior captação de desembolsos do BNDES no país, no período de 2001 a 2008, o equivalente a $65,7 \%$ do total. Borges reforça que o Estado de São Paulo, capta em quase todos os tipos de desembolso, exceto para o desenvolvimento tecnológico e aquisição e recuperação de máquinas agrícolas.

De maneira geral, de acordo com os dados da Companhia Nacional de Abastecimento (Conab) é possível verificar que a área cultivada com cana-de-açúcar 
que colhida e destinada à atividade sucroenergética na safra 2012/13, distribuída entre todos os Estados produtores no Brasil, estava estimada em torno de 8.527,8 mil hectares. Sendo que no caso do Estado de São Paulo, que tem se apresentado como o maior produtor, a área plantada ficou em torno de 4.419,46 mil hectares, o que significa dizer que $51,82 \%$ da área total plantada no país ocorreu neste Estado, seguido por Minas Gerais com 8,46\% (721,86 mil hectares), Goiás com 8,69\% (741,38 mil hectares), Paraná com 7,13\% (608,38 mil hectares), Mato Grosso do Sul com 6,50\% (554,29 mil hectares), Alagoas com 5,26\% (448,86 mil hectares) e Pernambuco com 3,63\% (309,74 mil hectares). (CONAB, 2012)

Ao analisar os dados do monitoramento anual do cultivo da cana-de-açúcar, realizado pelo Instituto Nacional de Pesquisas Espaciais (INPE) ${ }^{13}$, pode-se verificar esta expansão da área plantada nos últimos 10 anos no Estado de São Paulo. (Mapas 02 e 03)

\footnotetext{
${ }^{13}$ Rudorff, B.F.T.; Aguiar, D.A.; Silva, W.F.; Sugawara, L.M.; Adami, M.; Moreira, M.A. Studies on the Rapid Expansion of Sugarcane for Ethanol Production in São Paulo State (Brazil) Using Landsat Data. Remote Sens. 2010, 2, 1057-1076. Disponível em: http://www.mdpi.com/2072-4292/2/4/1057. Acesso em Março de 2014. Adami, M.; Mello, M.P.; Aguiar, D.A.; Rudorff, B.F.T.; Souza, A.F. A Web Platform Development to Perform Thematic Accuracy Assessment of Sugarcane Mapping in South-Central Brazil. Remote Sens. 2012, 4, 3201-3214. Disponível em: http://www.mdpi.com/20724292/4/10/3201. Acesso em Março de 2014.
} 


\section{Estado de São Paulo - área plantada com cana-de-açúcar (2003 - 2013)}
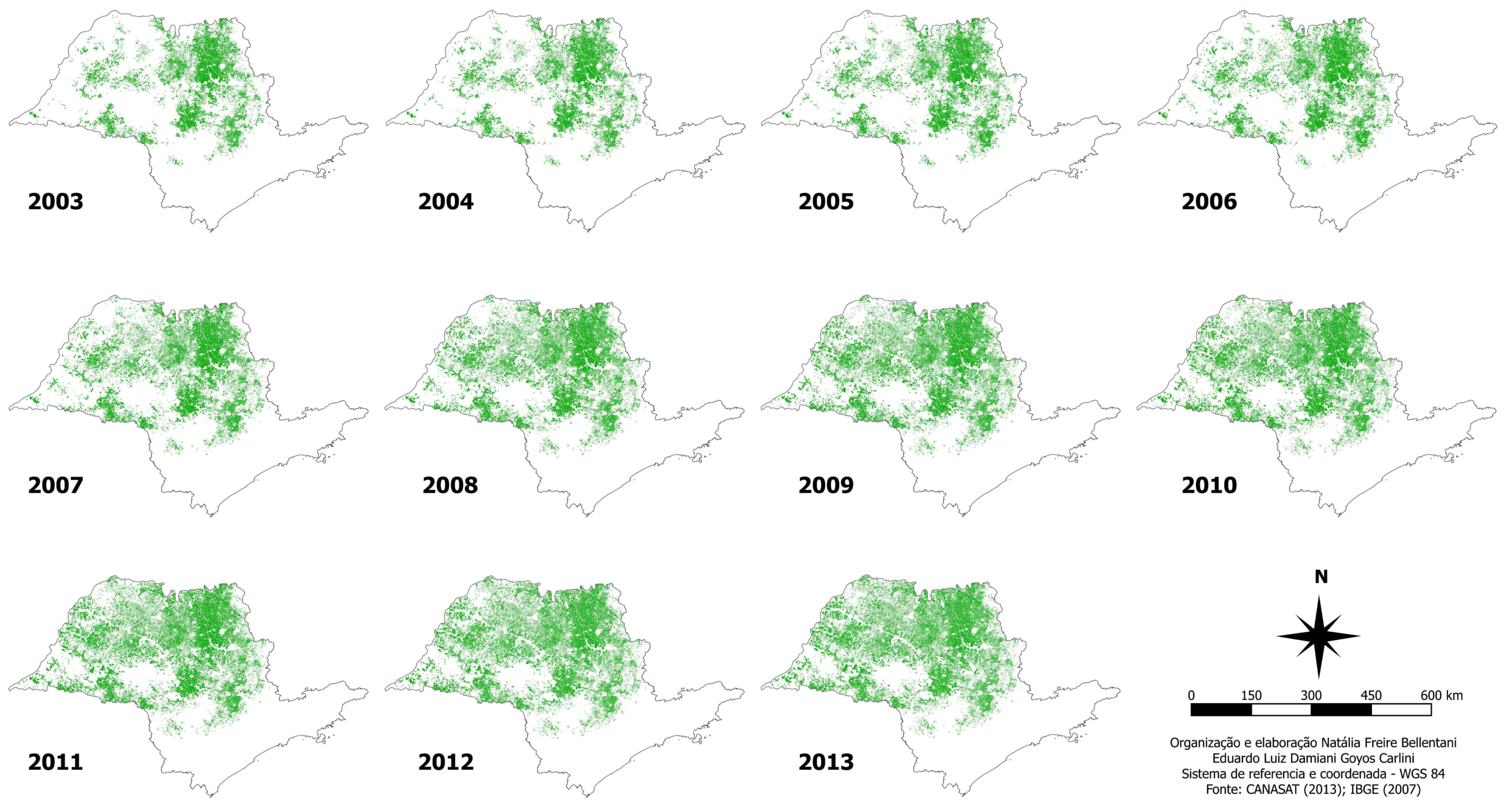


\section{Estado de São Paulo - área plantada com cana-de-açúcar (2003 - 2013)}

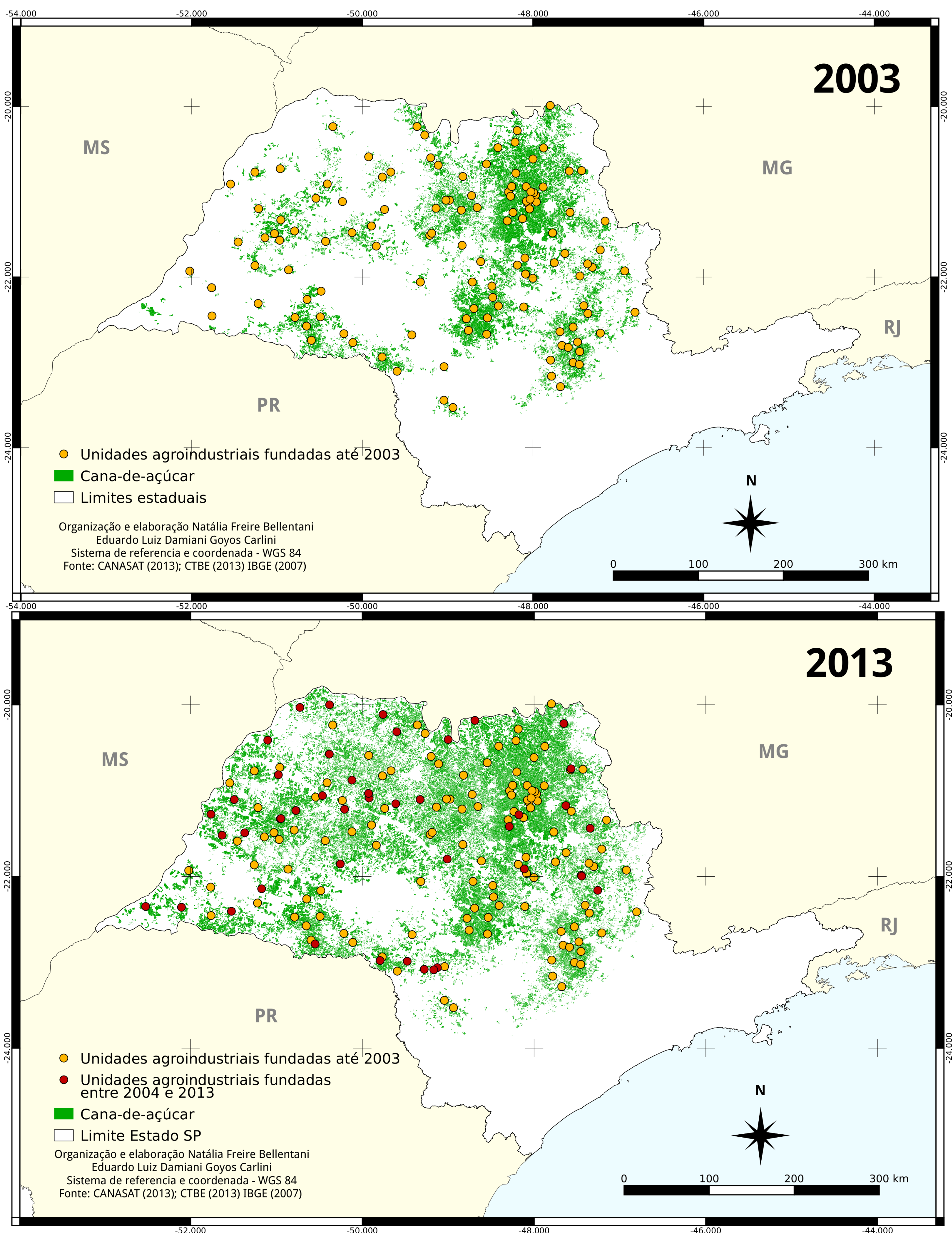


Quanto aos valores referentes a área plantada com cana-de-açúcar no Estado de São Paulo pode-se conferir também, ao analisar os dados publicados pela União da Indústria de Cana-de-Açúcar (UNICA) que a evolução da área plantada com canade-açúcar no Estado de São Paulo em relação ao Brasil é bastante significativa. A expansão do cultivo e o aumento vertiginoso do número de hectares ocupado com esta cultura podem ser vistos de forma evidente, pois, em 1980 esse valor estava na casa de 1.088.480 milhão de hectares, chegando em 1990 a um valor total de 1.811.980 milhão de hectares, em 2000 chegava a 2.484 .790 milhões de hectares, e em 2012 a 5.172.611 milhões de hectares. (Gráfico 01)

Gráfico 01: Área Plantada (ha) com cana-de-açúcar no Brasil e no Estado de São Paulo (1980 - 2010).

\section{Área Plantada (ha) com cana-de-açúcar $(1980$ - 2010) Brasil e Estado de São Paulo.}

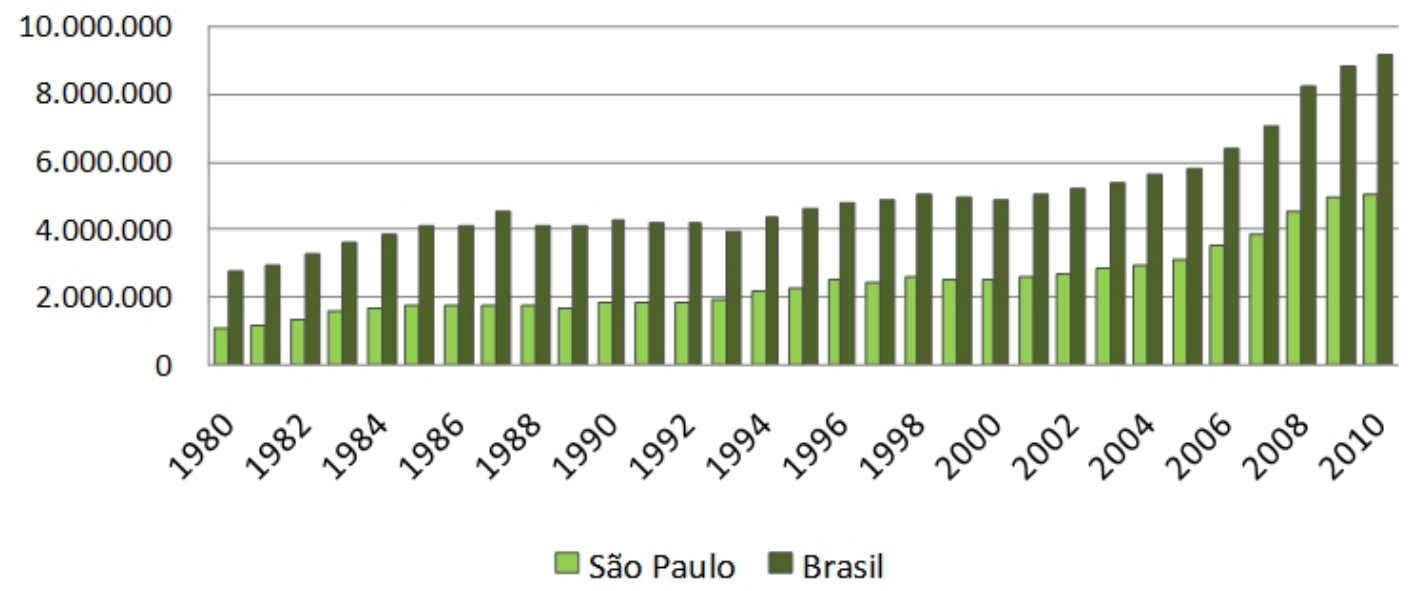

Fonte: União da Indústria de Cana-de-Açúcar (UNICA) Org. Natália Freire Bellentani (2012)

No que tange a produção de açúcar e etanol, é o Estado de São Paulo que mais se destaca, apresentando para os últimos 30 anos um crescimento ascendente. Sendo que em 1981 apresentava uma produção de 3,915 milhões de toneladas de açúcar, em 1991, 4,510 milhões, em 2001, 12,350 milhões e em 2013 chegou a 23,963 milhões de toneladas. (Gráfico 02). 
Gráfico 02: Produção de açúcar no Brasil e no Estado de São Paulo (1980 2013).

Produção açúcar (mil toneladas) - 1980/1981 até 2013/2014

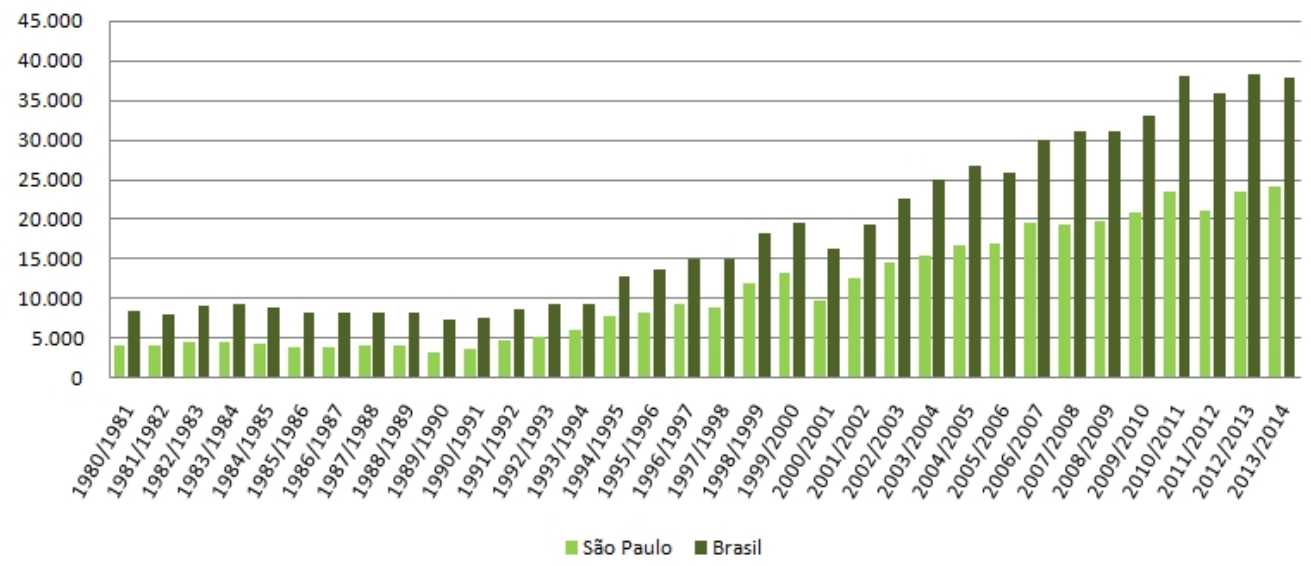

Fonte: União da Indústria de Cana-de-Açúcar (UNICA) Org. Natália Freire Bellentani (2012)

Esta lógica de aumento de produção do açúcar também se repetiu para a produção do etanol no Estado de São Paulo, como pode ser verificado em 1981 apresentava-se uma produção de 2,834 milhões m3 de etanol, em 1991, 8,579 milhões m3, em 2001, 7,135 milhões m3 e em 2013 chegou a 13,944 milhões m3 de etanol produzido no Estado. (Gráfico 03)

Gráfico 03: Produção de etanol no Brasil e no Estado de São Paulo (1980 2013).

Etanol Total (mil m³)- 1980/1981 até 2013/2014

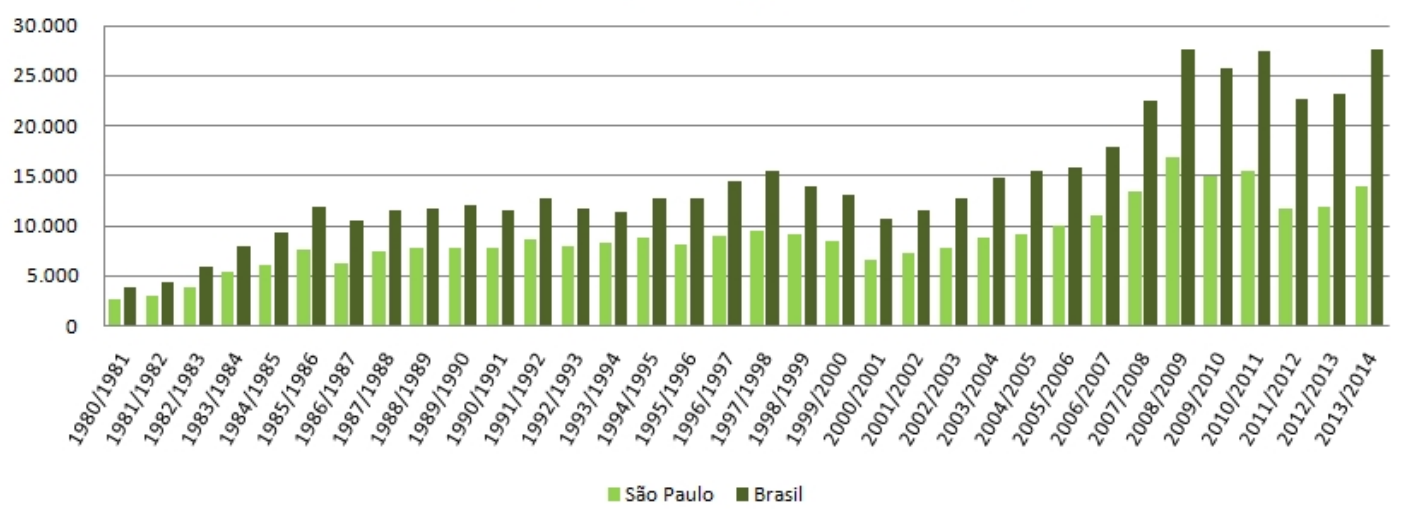

Fonte: União da Indústria de Cana-de-Açúcar (UNICA) Org. Natália Freire Bellentani (2012)

Ademais, apresenta-se aqui o levantamento de área e produção da monocultura da cana no Estado de São Paulo, de acordo com os dados do Instituto de Economia Agrícola (IEA) para o ano de 2013. (Mapas 04 e 05) 


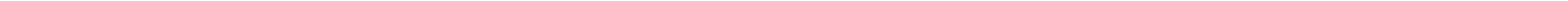




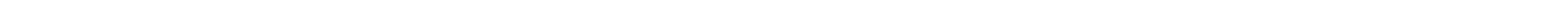


Compreender a pressão que este avanço do monopólio na produção de cultura da cana-de-açúcar exerce sobre a pequena, média e grande unidade de produção é também fundamental visto que mais de $50 \%$ do total da cana plantada no país, encontra-se no Estado de São Paulo. Lembrando que essa expansão se dá tanto pela compra como pela prática do arrendamento de novas áreas e, portanto acarreta em rebatimentos importantes no campo paulista.

Sendo assim, expõe-se aqui que a marca registrada desse setor é o apelo ao "início de uma nova era", referindo-se a uma "nova revolução verde" agora sustentada, sobretudo, pelos organismos geneticamente modificados, novas variedades e alta tecnologia. Em sentido contrário, esta (re)atualização do passado, travestida de modernidade, mantém características históricas dos diferentes "ciclos da cana-deaçúcar", por exemplo: unificação das classes dominantes no controle do poder do Estado; sujeição da renda da terra ao capital; concentração da propriedade da terra; expropriação dos camponeses e exploração dos trabalhadores assalariados da terra.

Nesse sentido, a difusão de um ideário neoliberal, propagandeado pelos monopólios que comandam a produção agrícola mundial, reflete não somente sobre a ciência e a tecnologia que passou a transformar o conhecimento em mercadoria, mas também ratifica a privatização e destruição dos recursos naturais, a violência no campo, os modelos de produção e as políticas governamentais e internacionais agrárias, pesqueiras e pecuárias que viabilizam esses monopólios em mãos de poucas empresas mundiais.

No interior deste entendimento procurou-se desenvolver as questões que envolvem a homogeneização de parcelas do território, desde o processo produtivo no 
campo até o processamento industrial da produção canavieira, ou seja, todos os momentos do processo de produção.

Dito isso, deve-se afirmar a preocupação e a centralidade do conceito de território no interior da ciência geográfica, e deste modo buscar-se-á realizar uma análise da territorialização do monopólio deste setor no interior do Estado de São Paulo, nas últimas décadas.

Neste contexto, por meio da análise das relações sociais, engendrada pelas diferentes formas que a luta de classes adquire historicamente e também pela incessante busca do conhecimento geográfico no que se refere ao desenvolvimento do capitalismo no campo, apresento aqui algumas questões que envolvem as relações entre a agricultura e a indústria, especificamente sobre o processo pelo qual o capital se instala na agricultura no Estado de São Paulo.

De início para compor esse quadro que remonta ao desenvolvimento do monopólio na produção agrícola - explicitado por este processo de expansão da agroindústria canavieira- é preciso destacar que a apropriação privada das terras, e sua consequente transformação em mercadoria no desenvolvimento do capitalismo no Brasil e este fato é determinante para a ampliação do processo de territorialização do setor sucroenergético.

Por meio desse breve panorama é possível observar parte das mudanças no campo brasileiro, especialmente o paulista, não só sob o aspecto agrícola e ambiental, mas (e principalmente) econômico e político que produzem a territorialização do setor sucroenergético no Estado de São Paulo. 
Desta forma, reforça-se que a compreensão da expansão das lavouras canavieiras e suas implicações causadas à sociedade brasileira, no território capitalista envolvido, são extremamente relevantes e severas.

Nesse sentido, a geografia, com suas teorias em constante construção e movimento, têm a necessidade de explicar essa problemática territorial e à sua maneira descrevê-la, servindo desse modo como um instrumento que permita a transformação desta realidade insustentável da expansão do capitalismo no campo paulista.

Assim sendo, em uma perspectiva científica, buscar-se-á compreender a realidade que se objetiva estudar, por meio desta lógica contraditória que opera sobre materialidades e imaterialidades, produzindo particularidades em cada fração do território capitalista.

Parte-se neste momento do trabalho para a expressão fática de processos, a expressão do real. Entendendo que quando se busca conhecer a realidade por meio da empiria pode-se ultrapassar inclusive o empírico e partir para a possibilidade de transformar a realidade na qual se está inserido.

Cabe aqui demonstrar que estudos realizados por Oliveira (2007) sobre este tema, mostram a expansão da cultura da cana-de-açúcar se faz na direção do bioma do cerrado. O mapa a seguir mostra a expansão das unidades agroindustriais do setor nesta direção. (Mapa 06) 
Mapa 06: Expansão da cultura da cana-de-açúcar na região Centro-Sul

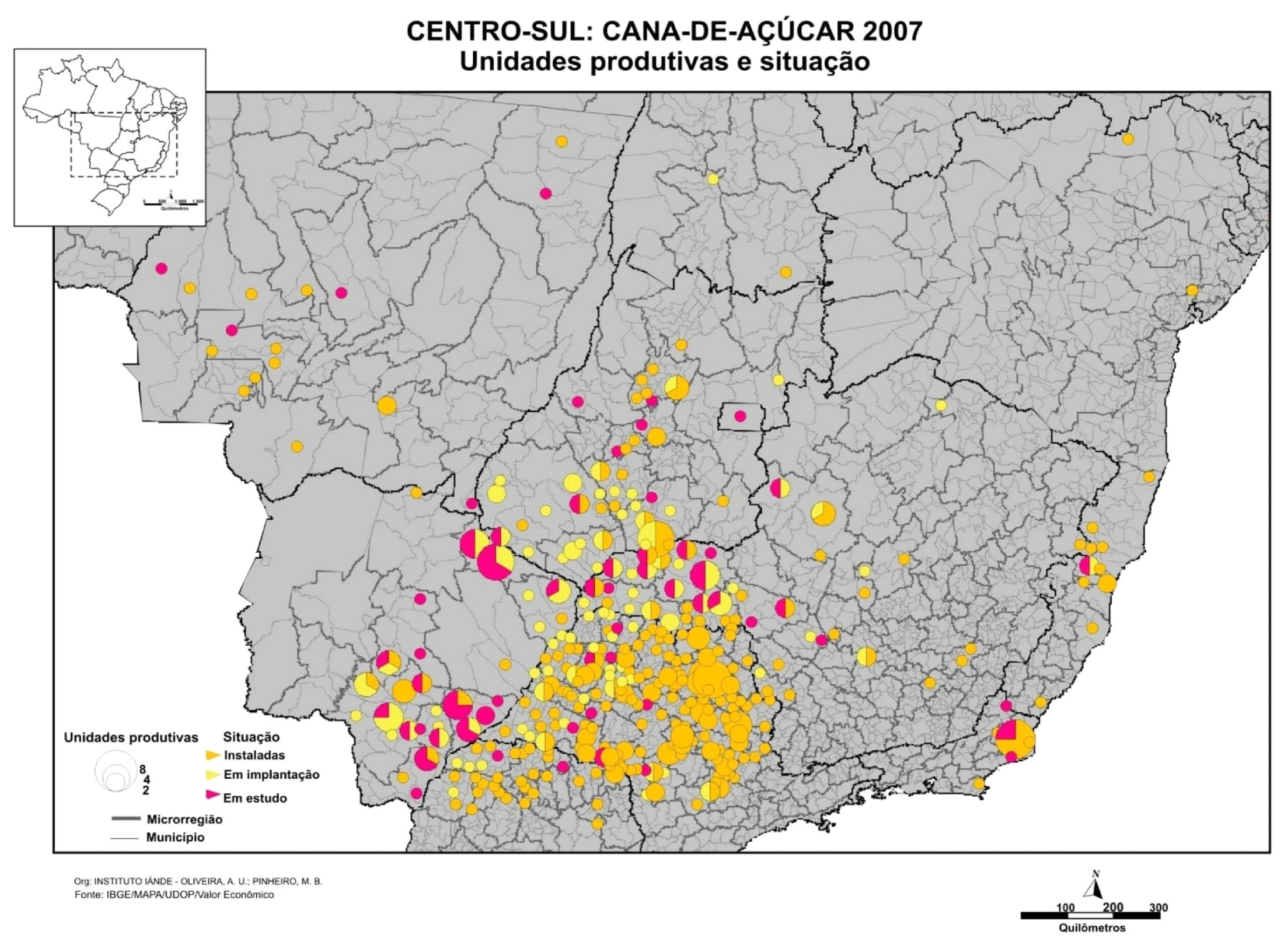


Assim, tendo em vista a preocupação em realizar por meio deste trabalho um mapeamento dos processos de territorialização do monopólio do setor sucroenergético, optei por trabalhar a partir dos dados do Instituto Brasileiro de Geografia e Estatística (IBGE), especialmente pela base do Sistema IBGE de Recuperação Automática SIDRA e também com o banco de dados do Instituto de Economia Agrícola - IEA/SP e Coordenadoria de Assistência Técnica Integral - CATI/SP, tendo-se como parâmetro a distribuição dos municípios por Escritório de Desenvolvimento Rural (EDR).

De acordo com a CATI/SP, estão distribuídos, nas várias regiões do Estado de São Paulo, um total de 40 Escritórios de Desenvolvimento Rural (EDRs), que englobam as Casas de Agricultura municipais que estão presentes em todos os municípios do Estado de São Paulo.

Sem dúvida alguma, em uma conjuntura histórica, como já destacado anteriormente, é possível observar que o processo de monopólio na produção de canade-açúcar vem se territorializando no interior do campo paulista. Ao mesmo tempo pode-se compreender que a terra no Estado de São Paulo e em todo o Brasil apresentase concretamente com a principal função de servir como reserva patrimonial e deste modo garantir aos proprietários (legítimos ou não) acesso a linhas de créditos públicos e ou privados, os quais vêm subsidiando este e outros setores da agropecuária.

A extraordinária oportunidade de geração de mais valor e renda para o setor sucroenergético tem provocado nas últimas décadas algumas transformações significativas para o setor e que dizem respeito desde o aumento vertiginoso da produção de cana-de-açúcar, passando pela abertura de novas plantas agroindustriais até a intensificação dos processos de fusões e aquisições dos grupos produtores. 
Os maiores grupos produtores no Estado de São Paulo, como é o caso da Cosan, que é também uma das maiores corporações empresariais de capital nacional, detentora de uma receita liquida declarada de R\$24,07 bilhões em 2011, só no Estado de São Paulo apresenta 22 unidades agroindustriais distribuídas por todas as regiões do campo paulista.

Oliveira afirmou ainda que na década de 1980 "este setor já vivia dos subsídios do Estado e este tem-se firmado ampliando o monopólio, de certa forma colocando-se no poder do Estado, através da 'fatia do bolo' que lhe tocou na atual estrutura de poder no país. " (OLIVEIRA, 1983)

Pode-se dizer que este quadro cristalizou-se nas últimas décadas, ampliado fortemente por políticas públicas favoráveis ao desenvolvimento da agroindústria canavieira, reforçando a fusão do capitalista industrial e do capitalista da agricultura na mesma pessoa (física ou jurídica).

Sobre esta expansão territorial e o declínio das atividades que eram representativas, especialmente laranja e pastagens tanto em grandes áreas de produção como nas pequenas unidades de produção, pode-se identificar que esta diferença está atrelada, especialmente, ao capital fixo investido no setor citrícola. Este por sua vez, vem determinando uma expansão territorial menos profunda, ao passo que nas áreas em que anteriormente apresentavam-se com as pastagens ocupando o solo, a incorporação de grandes áreas (até mesmo improdutivas ou terras públicas griladas) pelo setor sucroenergético se dá de forma muito mais rápida e significativa e deste modo determina a apropriação capitalista da terra pelo setor sucroenergético.

Vale ressaltar que este avanço de produção e áreas de cultivo de cana-de-açúcar, embora apresentem diferenças em relação ao processo como o crescimento se dá nas 
diferentes regiões do Estado de São Paulo. Configurou-se, pois, praticamente, em todos os municípios analisados, como pode ser verificado nessa pesquisa, o que dá condições de afirmar que o uso e ocupação das terras no quadro atual do campo paulista tem se configurado quase que exclusivamente, pelo cultivo superlativo da cana-de-açúcar para produção de açúcar, commodities de exportação, e de álcool para o abastecimento do mercado interno.

Oliveira (2007), mostrou também este processo de monocultivo que a expansão da cana-de-açúcar traz consigo, destruindo qualquer possibilidade de se estabelecer uma política de soberania alimentar nestas áreas. (Mapa 07) 
Mapa 07: Participação percentual da área plantada em relação à área do município Estado de São Paulo

SÃO PAULO E ENTORNO: CANA-DE-AÇÚCAR 2005

Participação percentual da área plantada em relação à área do município

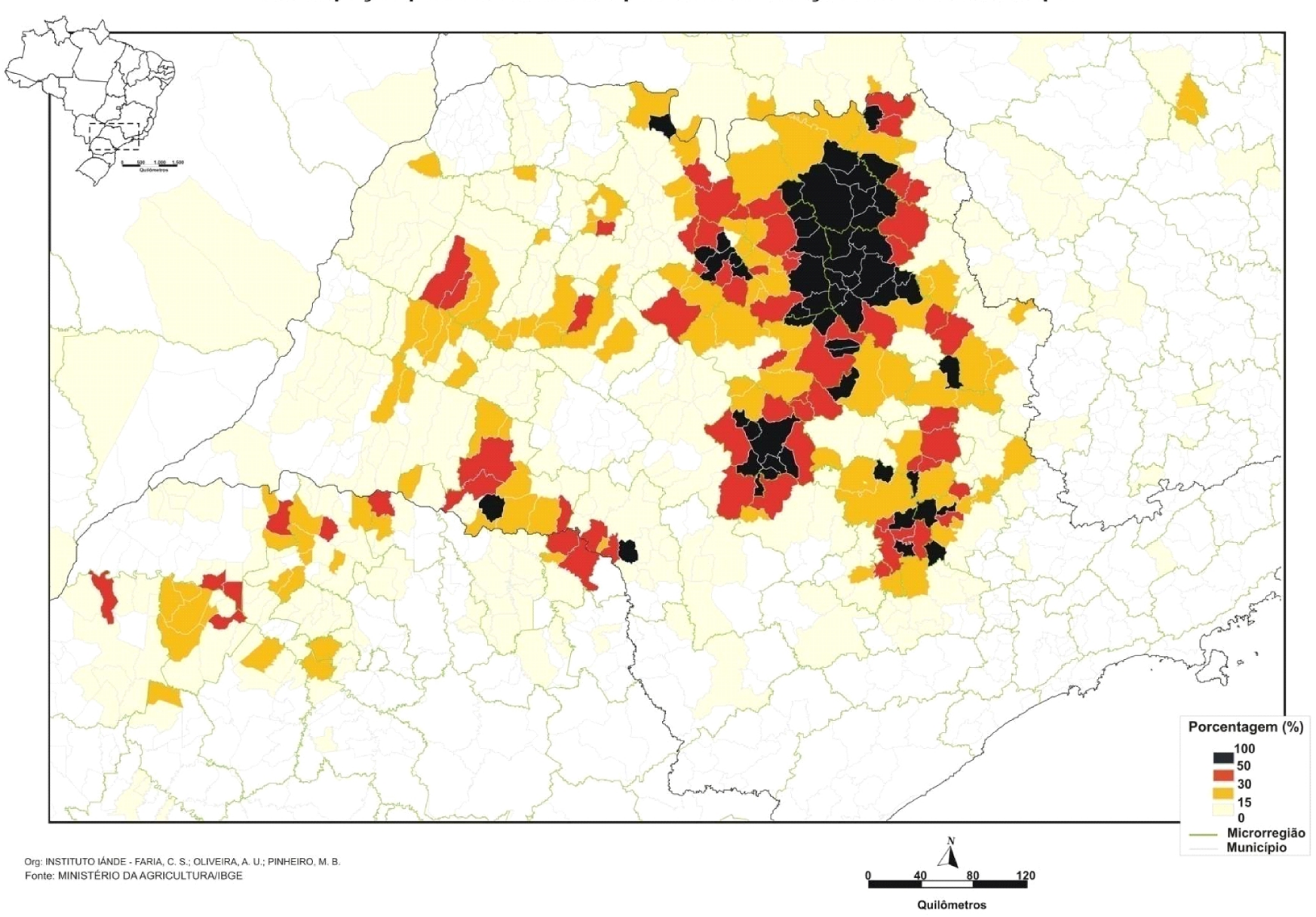


Tenho clareza que as pesquisas diretas devem contribuir para explicar as consequências deste avanço da produção de cana-de-açúcar no Estado de São Paulo. Neste sentido, faz-se imperativo a realização deste tipo de investigação e estudos científicos, com o intuito de esclarecer e entender este movimento da realidade da agricultura paulista capitalista.

Assim, é preciso considerar que esta tese busca as determinantes econômicas e sociais que podem contribuir para a compreensão, na ótica da geografia, deste uso do território capitalista pelo setor sucroenergético. Ou seja, o que está em jogo é a necessidade de avançar com essa discussão a fim de se compreender o controle da propriedade da terra e a fusão territorial monopolística da agroindústria canavieira.

Importa lembrar que a partir da investigação realizada sobre o setor definiu-se momentos históricos marcantes no processo de desenvolvimento da agroindústria canavieira a partir da década de 1990. Assim, demarca-se aqui o primeiro momento importante, a partir da década de 1990 com a desregulamentação do setor, seguido pelo crescimento e medidas colaborativas do Estado brasileiro para a produção de etanol e a manutenção e aumento da produção de açúcar, durante a década de 2000 e por fim, o momento mais recente que enlaça uma crise do neoliberalismo e as estratégias do setor para sua manutenção no mercado em 2012.

O Estado de São Paulo pós-desregulamentação do setor, acompanhando o boom das commodities nos anos 2000 aumentou suas áreas de cultivo de cana-de-açúcar, bem como sua capacidade de moagem. Na década seguinte o governo estadual com vistas às políticas ambientais apresentou projetos com medidas que teoricamente teriam o objetivo de regularizar o aumento de área cultivada, nesta relação criou-se, por 
exemplo, o Zoneamento Agroambiental da Cana-de-Açúcar no Estado de São Paulo ${ }^{14}$.

O governo definiu as áreas adequadas ao cultivo, mas de forma alguma, restringiu a

concentração econômica no setor e consequente formação dos grupos monopolistas

empresariais. (Mapa 08)

14 “O Zoneamento Agroambiental da cana-de-açúcar no Estado de São Paulo (ZAA) foi estabelecido em 18 de setembro de 2008, através de uma parceria entre as Secretarias do Meio Ambiente e da Agricultura e Abastecimento do Estado, com o principal objetivo de disciplinar e organizar a expansão e ocupação do solo pelo setor sucroenergético, além de subsidiar a elaboração de políticas públicas voltadas para as questões relacionadas ao setor. Utilizando bases de dados sobre condições climáticas, qualidade do ar, relevo, solo, disponibilidade e qualidade de águas superficiais e subterrâneas, unidades de conservação existentes e indicadas, incluindo áreas de proteção ambiental e fragmentos florestais para incremento da conectividade, foi criado um mapa único, que indica áreas adequadas e inadequadas para o cultivo de cana, e regula a ocupação das terras, a instalação e ampliação de unidades agroindustriais.” Disponível em: <www.ambiente.sp.gov.br/etanolverde/zoneamento-agroambiental/> . Acesso em Julho 2012. 


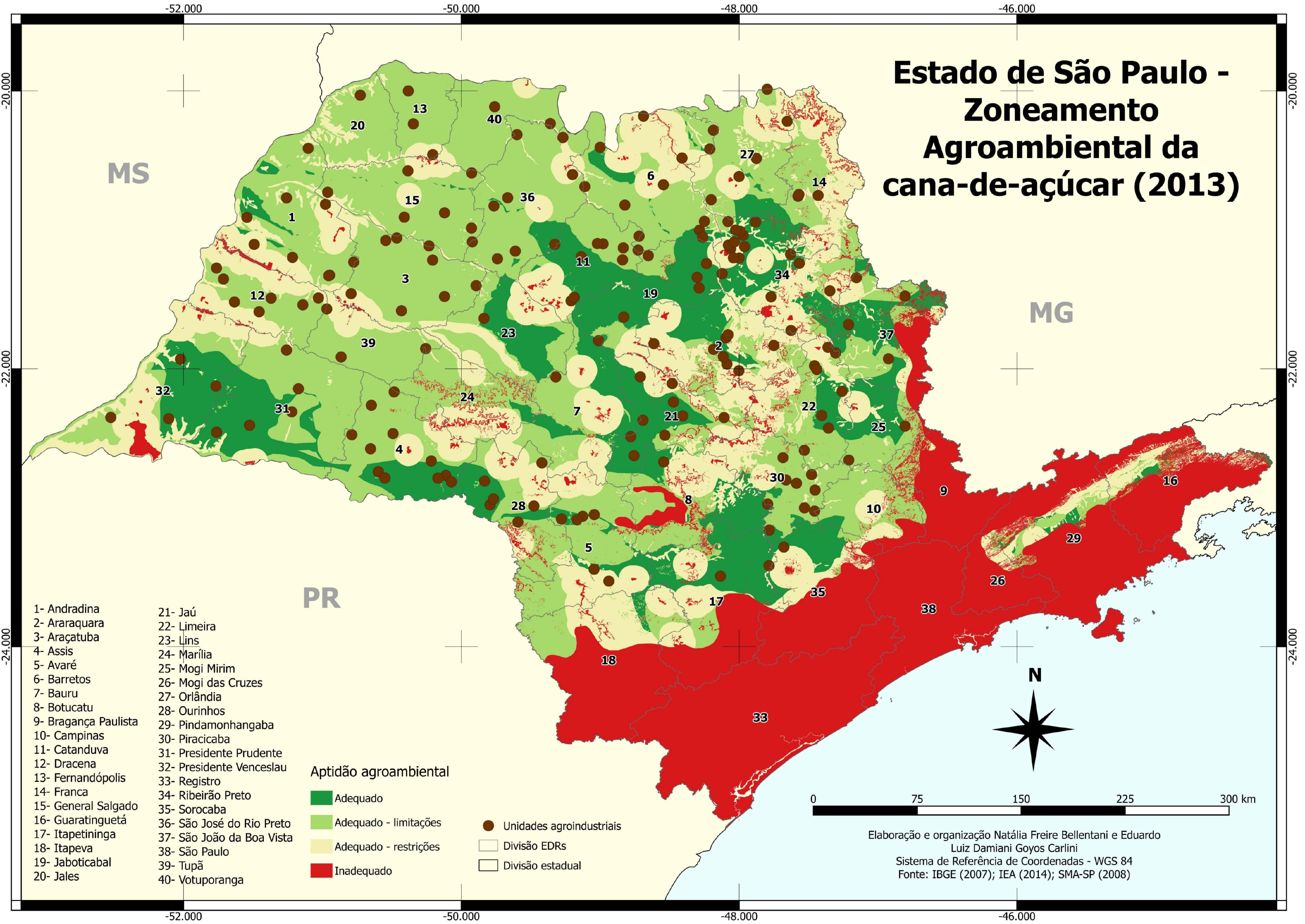


Das estratégias do setor para sua manutenção no mercado, reafirmando o que foi aqui apontado anteriormente as fusões e aquisições $(\mathrm{F} \& A)^{15}$ foram recorrentes:

[...] por vários fatores, parte dos quais afetaram a economia brasileira e as empresas de modo geral e outros tiveram impactos específicos sobre determinadas empresas e setores. Estão dentre os primeiros a onda neoliberal, com reflexos diretos sobre a abertura comercial e a desregulamentação da economia e o processo de internacionalização da economia mundial que suscitou, por parte das empresas, ações contínuas em busca de competitividade. Dentre os que afetaram especificamente empresas e setores, estão as condições de acesso ao mercado, a superação das barreiras à entrada e a incorporação de tecnologia e de "know-how" (BORGES E COSTA, 2008, p. 2).

Fusões dentro de uma mesma indústria ou fusões de empresas até mesmo concorrentes foram determinantes para concentrar rapidamente o capital e controlar o território com maior facilidade seja do ponto de vista da produção ou distribuição.

Sobre este especifico momento de desenvolvimento da agroindústria canavieira,

Oliveira (2014, Obra Inédita) destacou que:

[...] a crise mundial de 2008 pôs em cheque as políticas neoliberais para a agricultura. São elas que estão no "olho do furacão". E, a crise atingiu em cheio o capital financeiro mundial, revelando o quanto ele não era o fundamento do modo capitalista de produção, mas sim, os monopólios empresariais. É por isso, que o setor sucroenergético no Brasil, passou a conhecer como fundamental, a formação dos grupos empresariais nacionais, que continuam a longa história de hegemonia neste setor. Reitero também, que essa formação e consolidação trouxeram consigo a tríade concentração econômica produto da integração vertical e horizontal ou "cartelização técnica" que deu origem aos grupos monopolistas empresariais, a concentração territorial que deu origem à territorialização dos monopólios e, a mundialização que fundiu a aliança de classe entre as burguesias nacionais no plano mundial. A concentração territorial aparece a partir das aquisições e fusões que fazem com que frações do território capitalista passem a ter o monopólio da propriedade da terra direto ou através de arrendamento, exercido pelos grupos econômicos monopolistas monocultores territorializados que se formam. [...] (OLIVEIRA, 2014, Obra Inédita.)

\footnotetext{
15 [...] um dos principais objetivos industriais de uma aquisição/fusão consiste em pegar uma parcela do mercado, especialmente quando for acompanhada pela aquisição de marcas comerciais, de redes de distribuição e de clientes cativos. (CHESNAIS, 1996, p. 64).
} 
Os grupos monopolistas empresariais tem feito a opção teórica, conhecida nas Business Schools norte americanas, onde descriminam suas atividades produtivas como clusters $^{16}$ (aglomerações regionais), ou até mesmo polos. O uso dessa denominação revela para as empresas, apoiadas na lógica do neoliberalismo, suas vantagens competitivas, bem como a concentração das propriedades privadas, a relação direta com instituições de pesquisa e articulação com outras empresas relacionadas ao setor. Oliveira (2014, Obra Inédita) ponderou que essa forma de organização dos grupos em clusters trata-se, de uma nova forma de utilização do conceito, similar ao conceito de arranjo produtivo local.

Todavia o autor refutou esta proposta do discurso neoliberal (cluster ou clustering) e da conceituação derivada da Geografia Quantitativa empirista lógica (análise de agrupamento ou aglomeração) e faz a opção pela proposta conceitual de fusão territorial monopolística (monopolistic territorial fusion) para designar a concentração territorial que aparece, a partir das aquisições e fusões que fazem com que frações do território capitalista passem a ter o monopólio da propriedade da terra direto ou através de arrendamento, exercido pelos grupos econômicos agroindustriais monocultores territorializados que se formam. (Oliveira, 2014, Obra Inédita)

Paralelamente é importante ter em conta que, ao longo desses anos marcados nessa trajetória a partir da abertura econômica do Brasil tendo as diretrizes do capital monopolista como balizadoras, o setor sucroenergético tem todos os seus avanços produzidos, assim como todo o agronegócio brasileiro, a partir da barbárie ${ }^{17}$. A

\footnotetext{
16 “A Raízen possui importante vantagem competitiva em função da organização de suas atividades produtivas em clusters (aglomerações regionais), os quais permitem uma maior eficiência logística e captura de sinergia nas operações das usinas". (Prospecto preliminar de distribuição pública das $1^{\mathrm{a}}$ e $2^{\mathrm{a}}$ séries da $10^{\mathrm{a}}$ emissão de certificados de recebíveis do agronegócio da RAÍZEN ENERGIA S.A.)

${ }^{17}$ OLIVEIRA, A. U. . Barbárie e Modernidade: as transformações no campo e o agronegócio no Brasil. Terra Livre, São Paulo-SP, v. 02, n.21, p. 113-156, 2004.
} 
superexploração dos trabalhadores é um exemplo dessa violência característica da "modernização" do campo no Brasil.

Nesse sentido, assumindo a luta entre as classes que compõem a totalidade de nossa sociedade, analisando a entrada das empresas no mercado financeiro e a consequente mundialização da agricultura, esta pesquisa inclinou-se ao estudo dos grupos econômicos que comandam o setor.

É preciso entender que a formação desses grupos no Brasil é recente, do ponto de vista histórico, e traz como balizadores primeiro o estabelecimento pleno das políticas neoliberais no país, a partir da abertura econômica na década de 1990, depois o desenvolvimento absoluto dessas políticas e mais recentemente sua crise. A austera aliança da burguesia nacional e internacional reflete-se tanto nas ações do Estado brasileiro em seus distintos governos bem como no movimento dos capitais, gerando uma nova racionalidade sobre a produção e arranjo territorial do setor sucroenergético.

As inúmeras associações, fusões e aquisições que ocorreram nas últimas décadas no setor sucroenergético são reflexos dessa multinacionalização que se dá por meio da ofensiva do capitalismo internacional monopolista, a qual se desenvolve em todo o mundo, sem mais exceções como anteriormente atribuídas aos países denominados periféricos, subdesenvolvidos e/ou em desenvolvimento. Esta nova lógica fortalece os grupos monopolísticos que a partir dos anos 2000 passam a operar como players no mercado das bolsas de mercadorias em todo o mundo.

Como destacou Oliveira "a agricultura sob o capitalismo monopolista mundializado, passou a estruturar-se sobre três pilares: a produção de commodities, as bolsas de mercadorias e de futuro e os monopólios mundiais."'(OLIVEIRA, 2014, Obra Inédita) 
[...] O primeiro visou transformar toda produção agropecuária, para o mercado mundial. Portanto, a produção de alimentos deixou ser questão estratégica nacional, e, passou a ser mercadoria a ser adquirida no mercado mundial onde quer que ela seja produzida. As principais commodities são: milho, trigo, arroz, soja, algodão, cacau, café, açúcar, suco de laranja, farelo e óleo de soja entre outras. No Brasil acrescenta-se também, o etanol e o boi gordo.

Segundo, as bolsas de mercadorias e futuro tornaram-se o centro regulador dos preços mundiais das commodities. A principal bolsa de comercialização de alimentos é a Bolsa de Chicago e, nela decidem-se os preços do milho, soja contrato Chicago, óleo de soja, farelo de soja, soja contrato Latinoamericano, trigo, álcool combustível ou etanol, aveia e arroz em casca, leite, carne bovina, carne suína, carne de frango, ovos e etc. $\mathrm{Na}$ Bolsa de Londres são definidos os preços do açúcar, cacau, café, etc. Na Bolsa de Nova York correm as cotações do algodão, açúcar, cacau, café e suco de laranja, etc. No Brasil, não tem sido diferente, a BM\&F/Bovespa atua inclusive, no mercado futuro de soja, milho, café, etanol e boi gordo.

Terceiro, a constituição dos monopólios mundiais permitiu o controle monopolista da produção das commodities do setor. Estas empresas mundiais têm nas multinacionais suas bases constituintes. Elas formaram-se pelo processo mundial de investimentos diretos de capitais através das filiais, fusões, associações, franquias, etc. As empresas mundiais nasceram, pois, tanto de empresas estrangeiras como das nacionais que possuindo o controle monopolista da produção galgam o patamar mundial associando-se majoritariamente com empresas nacionais concorrentes. Em nível internacional há quatro empresas que controlam, praticamente, todo o mercado de alimentos no mundo.[...]." (OLIVEIRA, 2014, Obra Inédita.)

Esta tríade a que se reportou Oliveira (2014, Obra Inédita) revela que a mundialização da agricultura nesta etapa monopolista do capital, desenvolve-se a partir de um processo que envolve tanto a internacionalização como a multinacionalização das empresas agropecuárias brasileiras. Ao mesmo tempo, é salutar lembrar que as empresas nacionais mantém o controle da gestão de seus negócios, como será possível observar nos dados que serão apresentados nesta pesquisa.

Considerando os distintos momentos históricos que marcam a trajetória do setor, identificam-se nos EDRs do Estado de São Paulo áreas que produzem cana-de-açúcar ${ }^{18}$

\footnotetext{
${ }^{18}$ A produção de cana-de-açúcar é uma atividade diferenciada de outras culturas. Em primeiro lugar, o produtor deverá verificar a distância de sua lavoura da unidade industrial, que não deverá ultrapassar 50 $\mathrm{km}$. Outros fatores a serem considerados, são: a longevidade, produtividade e qualidade da matéria-prima. Estes fatores devem ser levados a sério, pois significam renda ou prejuízo na atividade. Principalmente para a lavoura de cana-de-açúcar que requer grandes investimentos para sua instalação e tem retorno mais demorado. Usualmente, em que produzem cana-de-açúcar a mais tempo regiões produtoras de cana
} 
a mais tempo e as áreas que vem produzindo de forma mais recente esta monocultura.

No caso das áreas que produzem há mais tempo, destacam-se os EDRs de Piracicaba,

Ribeirão Preto, Jaú, Jaboticabal e Limeira e para as áreas mais recentes, os EDRs de Andradina, Araçatuba, Presidente Prudente, São José do Rio Preto e Lins.

Nas tabelas 01 e 02 é possível verificar os municípios que compõem cada EDR e que serão analisados, a fim de demonstrar a evolução das áreas plantadas e colhidas, quantidade produzida e produtividade da agroindústria canavieira. E a partir dessa leitura procurou-se compreender a territorialização dos grandes grupos monopolistas no Estado de São Paulo.

Para analisar o alastramento da produção da cana-de-açúcar no Estado de SP, adotou-se como recorte territorial o Escritório de Desenvolvimento Rural (EDR) de Ribeirão Preto, que compreende 19 municípios, dos quais 19 possuem produção de cana-de-açúcar; Piracicaba, com 16 municípios e 16 que cultivam cana-de-açúcar; Jaú com 14 municípios e 14 que cultivam cana-de-açúcar; Jaboticabal com 14 municípios e 14 que cultivam cana-de-açúcar; e Limeira com 14 municípios e 14 que também cultivam cana-de-açúcar.

utiliza-se de uma distância econômica padrão da produção até a indústria, de 20 quilômetros. Esta distância é determinada pelos altos custos de transporte da cana até a unidade industrial, sendo um dos fatores decisivos na rentabilidade da lavoura. Como exemplo: $\mathrm{O}$ produtor que tiver que deslocar a cana para ser processada em uma unidade industrial distante $50 \mathrm{Km}$ de sua lavoura, terá um acréscimo no custo de produção de $13 \%$. Já uma cana distante $5 \mathrm{Km}$ da unidade industrial terá um custo inferior em $7 \%$ ao de uma lavoura distante $20 \mathrm{Km}$ da unidade industrial. A produtividade é medida em toneladas por hectares. De acordo com pesquisadores, um bom retorno econômico é de 85 toneladas por hectare. A produtividade é influenciada pelas condições climáticas, pelos tratos culturais e escolha da variedade adequada de sua região. A longevidade refere-se ao número de cortes da cana. Tal fator está ligado às condições de clima, solo e tratos culturais. O melhor resultado econômico é de cinco cortes, ou seja, a partir deste valor, se o produtor conseguir uma vida útil maior do canavial terá resultados econômicos melhores. Além da produtividade, a unidade industrial exige a qualidade da matéria-prima que é fator preponderante para a sua remuneração. Todo esse processo reafirma a hegemonia total do modo de produzir capitalista na agricultura, assumidamente no setor sucroenergético. Nesse sentido é possível dizer que o crescimento/expansão da cana, bem como a formação dos grupos estão vinculados ao controle do território. (Cana-de-açúcar - orientações para o setor canavieiro. Brasília: CNA/ SENAR, 2007.) 
Tabela 01: Municípios que fazem parte dos Escritórios de Desenvolvimento Rural (EDR) que produzem cana-de-açúcar há mais tempo.

Escritório de

Desenvolvimento Municípios que fazem parte do EDR

Rural (EDR)

Piracicaba

Ribeirão Preto

Jaú

Jaboticabal

Borborema - Cândido Rodrigues - Dobrada - Fernando Prestes - Guariba Ibitinga - Itápolis - Jaboticabal - Monte Alto - Santa Ernestina - Taiaçu Taiúva - Taquaritinga - Vista Alegre do Alto -

Limeira

Analândia - Araras - Cordeirópolis - Corumbataí - Ipeúna - Iracemápolis Itirapina - Leme - Limeira - Pirassununga - Porto Ferreira - Rio Claro Santa Cruz da Conceição - Santa Gertrudes -

$\overline{\text { Fonte: }}$ Coordenadoria de Assistência Técnica Integral - CATI/SP (2012)

Para as áreas de produção de cana-de-açúcar mais recentes que apresentam um crescimento muito positivo para o setor nos últimos anos, sobretudo no eixo oeste do Estado de São Paulo, adotou-se como recorte territorial os Escritórios de Desenvolvimento Rural (EDR) de Andradina que compreende 13 municípios, dos quais 13 possuem produção de cana-de-açúcar; Araçatuba, com 19 municípios e 13 que cultivam cana-de-açúcar; Presidente Prudente, com 21 municípios e 20 que cultivam cana-de-açúcar; Rio Preto, com 24 municípios e 24 que cultivam cana-de-açúcar e Lins, com 13 municípios e 13 que cultivam cana-de-açúcar. Todas essas informações apresentadas para o Estado de São Paulo tiveram como referência os dados do Instituto de Economia Agrícola e Coordenadoria de Assistência Técnica Integral - 
CATI/Secretaria de Agricultura e Abastecimento do Estado de São Paulo, entre os anos de 2000-2011.

Tabela 02: Municípios que fazem parte dos Escritórios de Desenvolvimento Rural (EDR) mais recentes no cultivo de cana-de-açúcar.

\begin{tabular}{|c|c|}
\hline $\begin{array}{l}\text { Escritório de } \\
\text { Desenvolvimento } \\
\text { Rural (EDR) }\end{array}$ & Municípios que fazem parte do EDR \\
\hline Andradina & $\begin{array}{l}\text { Andradina - Bento de Abreu - Castilho - Guaraçaí - Ilha Solteira - Itapura - } \\
\text { Lavínia - Mirandópolis - Murutinga do Sul - Nova Independência - Pereira } \\
\text { Barreto - Suzanápolis - Valparaíso - }\end{array}$ \\
\hline Araçatuba & $\begin{array}{l}\text { Alto Alegre - Araçatuba - Avanhandava - Barbosa - Bilac - Birigui - Braúna - } \\
\text { Brejo Alegre - Clementina - Coroados - Gabriel Monteiro - Glicério - Guararapes } \\
\text { - Luiziânia - Penápolis - Piacatu - Rubiácea - Santópolis do Aguapeí - }\end{array}$ \\
\hline Presidente Prudente & $\begin{array}{l}\text { Alfredo Marcondes - Álvares Machado - Anhumas - Caiabu - Emilianópolis - } \\
\text { Estrela do Norte - Iepê - Indiana - João Ramalho - Martinópolis - Nantes - } \\
\text { Narandiba - Pirapozinho - Presidente Bernardes - Presidente Prudente - } \\
\text { Rancharia - Regente Feijó - Sandovalina - Santo Expedito - Taciba - Tarabaí - }\end{array}$ \\
\hline $\begin{array}{l}\text { São José do Rio } \\
\text { Preto }\end{array}$ & $\begin{array}{l}\text { Adolfo - Bady Bassitt - Bálsamo - Cedral - Guapiaçu - Icém - Ipiguá - Jaci - José } \\
\text { Bonifácio - Mendonça - Mirassol - Mirassolândia - Monte Aprazível - Neves } \\
\text { Paulista - Nipoã - Nova Aliança - Nova Granada - Onda Verde - Palestina - } \\
\text { Poloni - Potirendaba - São José do Rio Preto - Tanabi - Ubarana - }\end{array}$ \\
\hline Lins & $\begin{array}{l}\text { Balbinos - Cafelândia - Getulina - Guaiçara - Guaimbê - Guarantã - Júlio } \\
\text { Mesquita - Lins - Pirajuí - Pongaí - Promissão - Sabino - Uru - }\end{array}$ \\
\hline
\end{tabular}

Fonte: Coordenadoria de Assistência Técnica Integral - CATI/SP (2012)

Este recorte está vinculado à representatividade e evolução positiva que a produção canavieira tem nas áreas agrícolas de cada EDR e ao mesmo tempo em cada um dos munícipios que compõem o EDR. De forma alguma está se negando que esta evolução também ocorra em outras áreas do Estado de São Paulo, mas a princípio, trabalhar-se-á com este significativo processo de territorialização destes complexos agroindustriais sobre as terras do campo paulista e posteriormente, com os próximos passos dessa pesquisa, apresentar-se-á outras áreas. 
Nas tabelas 03 e 04, é possível observar a evolução da área (ha) plantada e a produção (t) de cana-de-açúcar para indústria nas últimas três décadas dos Escritório de Desenvolvimento Regional (EDR) selecionados como áreas de ocupação a mais tempo dessa monocultura, quais sejam: Piracicaba; Ribeirão Preto; Jaú; Jaboticabal; e Limeira. Nestes EDRs, conhecidos como os núcleos provedores da racionalidade do setor sucroenergético, tanto em relação a área cultivada, como no que tange a produção, o setor mantém-se em ascensão, como se pode verificar pelos dados. Nestes EDRs a área plantada total com cana cresceu 44,1\% entre 1990 e 2010.

Tabela 03: Evolução da área (ha) plantada de cana-de-açúcar para indústria nas últimas três décadas nos Escritórios de Desenvolvimento Rural (EDR) de Piracicaba; Ribeirão Preto; Jaú; Jaboticabal; e Limeira

\begin{tabular}{|c|c|c|c|}
\hline \multirow[t]{2}{*}{ Escritório de Desenvolvimento Rural (EDR) } & \multicolumn{3}{|c|}{ Área (ha) de cana-de-açúcar } \\
\hline & 1990 & 2000 & 2010 \\
\hline PIRACICABA & 181.900 & 166.457 & 206.652 \\
\hline RIBEIRÃO PRETO & 266.870 & 323.723 & 378.870 \\
\hline JAÚ & 195.614 & 217.912 & 278.543 \\
\hline JABOTICABAL & 135.299 & 175.446 & 266.924 \\
\hline LIMEIRA & 127.610 & 130.694 & 176.624 \\
\hline
\end{tabular}

$\overline{\text { Fonte: IEA; SIDRA-IBGE, 2012. (Organização: Natália Freire Bellentani) }}$

É interessante notar que quando se trabalha com as áreas de cultivo a mais tempo da monocultura da cana-de-açúcar, ainda na década de 1990, as expressões numéricas relacionadas ao tamanho das áreas ocupadas com a monocultura já excediam as cifras que hoje podem começar a ser alcançadas e verificadas para as áreas de ocupação mais recente da cultura, valores estes que ultrapassam os $180 \mathrm{mil}$ ha em média para os respectivos EDRs. 
No que tange a produção é possível verificar esta mesma configuração, onde as áreas de cultivo a mais tempo mantém seu crescimento em ritmo gradual enquanto, as áreas de cultivo mais recente, apresentam um patamar evolutivo exponencial, que tem levado a ampliação dessa ocupação territorial no interior do Estado de São Paulo. O crescimento do volume total da produção de cana entre 1990 e 2010 foi de $58 \%$ nestes EDRs.

Tabela 04: Produção $(\mathrm{t})$ de cana-de-açúcar para indústria nas últimas três décadas nos Escritórios de Desenvolvimento Rural (EDR) de Ribeirão Preto, Piracicaba, Jaú, Limeira e Jaboticabal.

\begin{tabular}{l|l|l|l}
\multirow{2}{*}{$\begin{array}{l}\text { Escritório de } \\
\text { Desenvolvimento Rural } \\
\text { (EDR) }\end{array}$} & \multicolumn{3}{c}{ Produção (ton) de cana-de-açúcar } \\
\cline { 2 - 4 } & $\mathbf{1 9 9 0}$ & $\mathbf{2 0 0 0}$ & $\mathbf{2 0 1 0}$ \\
\hline PIRACICABA & 10.870 .500 & 10.826 .604 & 13.865 .764 \\
\hline RIBEIRÃO PRETO & 16.698 .100 & 21.497 .598 & 26.026 .816 \\
\hline JAÚ & 12.535 .050 & 14.550 .920 & 21.476 .033 \\
\hline JABOTICABAL & 9.593 .120 & 10.959 .120 & 19.837 .363 \\
\hline LIMEIRA & 9.409 .500 & 9.110 .100 & 12.187 .257 \\
\hline
\end{tabular}

Fonte: IEA; SIDRA-IBGE, 2012. (Organização: Natália Freire Bellentani)

Como afirmou Souza (2008) o processo de territorialização destas áreas que produzem cana-de-açúcar a mais tempo vem acompanhado de uma ampla inserção deste setor em projetos governamentais, como é o caso do Proálcool, na década de 1970 que viabilizou as atividades com expressivos investimentos (SZMRECSÁNY, 1996; BACCARIN, 1994, 2005) e que hoje, mais de 40 anos depois se repete por meio das política públicas viabilizadas tanto pelo governo federal, quanto estadual, para o 
crescimento das usinas e destilarias por todo o Estado de São Paulo e também em outros estados brasileiros, como é o caso expressivo do Mato Grosso do Sul e Paraná.

Deste modo, nas tabelas 05 e 06, é possível observar a evolução da área (ha) plantada e produção (t) de cana-de-açúcar para indústria nas últimas três décadas dos Escritórios de Desenvolvimento Regional (EDR) selecionados como as áreas de expansão do setor mais recentes, quais sejam: Andradina; Araçatuba; Presidente Prudente; São José do Rio Preto; e Lins.

Tabela 05: Área (ha) plantada de cana-de-açúcar para indústria nas últimas três décadas nos Escritórios de Desenvolvimento Rural (EDR) de Andradina, Araçatuba, Presidente Prudente, São José do Rio Preto e Lins.

Escritório de Desenvolvimento Rural (EDR)

Área (ha) de cana-de-açúcar

\begin{tabular}{|c|c|c|c|}
\hline \multirow[b]{3}{*}{ ANDRADINA } & \\
\hline & 1990 & 2000 & 2010 \\
\hline & 26.227 & 54.743 & 258.752 \\
\hline ARAÇATUBA & 76.783 & 96.153 & 270.232 \\
\hline P. PRUDENTE & 28.592 & 46.914 & 245.636 \\
\hline RIO PRETO & 26.946 & 35.544 & 269.857 \\
\hline LINS & 20.447 & 32.746 & 176.352 \\
\hline
\end{tabular}

Fonte: IEA; SIDRA-IBGE, 2012. (Organização: Natália Freire Bellenatani)

Como é possível observar em todos os EDRs de cultivo mais recente da monocultura da cana-de-açúcar, apresentaram um crescimento muito expressivo de área plantada, sendo que o EDR de Rio Preto se destaca com 269.857 mil hectares em 2010 em relação aos 26.946 mil hectares que cultivava na década de 1990. Há nestes EDRs um vertiginoso crescimento do total da área cultivada entre 1990 e 2010 de $682 \%$. 
No que tange a produção pode-se novamente observar que estes EDRs apresentaram um crescimento ascendente e os valores de toneladas produzidas aumentaram significativamente, seja no EDR Andradina que sai de um total produzido em 1990 de 1.641 .080 milhão de toneladas e chega em 2010 com um total de 20.842.554 milhões de toneladas, seja no EDR São José do Rio Preto, onde essa variação saiu de 1.955.841 milhão de toneladas e chegou a 19.354 .821 milhões de toneladas. Em termos totais o volume de produção de cana dos EDRs, entre 1990 e 2010, cresceu também, de forma vertiginosa 791,4\%. (Tabela 06)

Tabela 06: Produção (t) de cana-de-açúcar para indústria no período de 2000 a 2011 nos municípios do Escritório de Desenvolvimento Rural (EDR) de Andradina, Araçatuba, Presidente Prudente, São José do Rio Preto e Lins.

Escritório de Desenvolvimento Rural (EDR)

Produção (ton) de cana-de-açúcar

\begin{tabular}{l|l|l|l}
\hline \multicolumn{2}{c|}{$\mathbf{1 9 9 0}$} & $\mathbf{2 0 0 0}$ & $\mathbf{2 0 1 0}$ \\
\cline { 1 - 4 } ANDRADINA & 1.641 .080 & 4.049 .915 & 20.842 .554 \\
ARAÇATUBA & 5.103 .950 & 6.704 .086 & 20.681 .102 \\
\hline P. PRUDENTE & 1.592 .935 & 2.631 .099 & 18.044 .210 \\
\hline RIO PRETO & 1.955 .841 & 2.542 .359 & 19.354 .821 \\
\hline LINS & 1.357 .870 & 2.279 .980 & 13.293 .743 \\
\hline
\end{tabular}

Fonte: IEA; SIDRA-IBGE, 2012. (Organização: Natália Freire Bellentani)

No gráfico a seguir é possível observar a relação entre uma das áreas que cultivam cana-de-açúcar a mais tempo (EDR de Ribeirão Preto) e uma das áreas de cultivo mais recente (EDR de Andradina) e verificar este patamar evolutivo positivo para ambos, possibilitado pelo apoio estatal, inclusive. (Gráfico 04) 
Gráfico 04: Evolução da área (ha) e produção (t) de cana-de-açúcar para indústria (1984-2011) dos Escritórios de Desenvolvimento Rural (EDR) de Andradina e de Ribeirão Preto

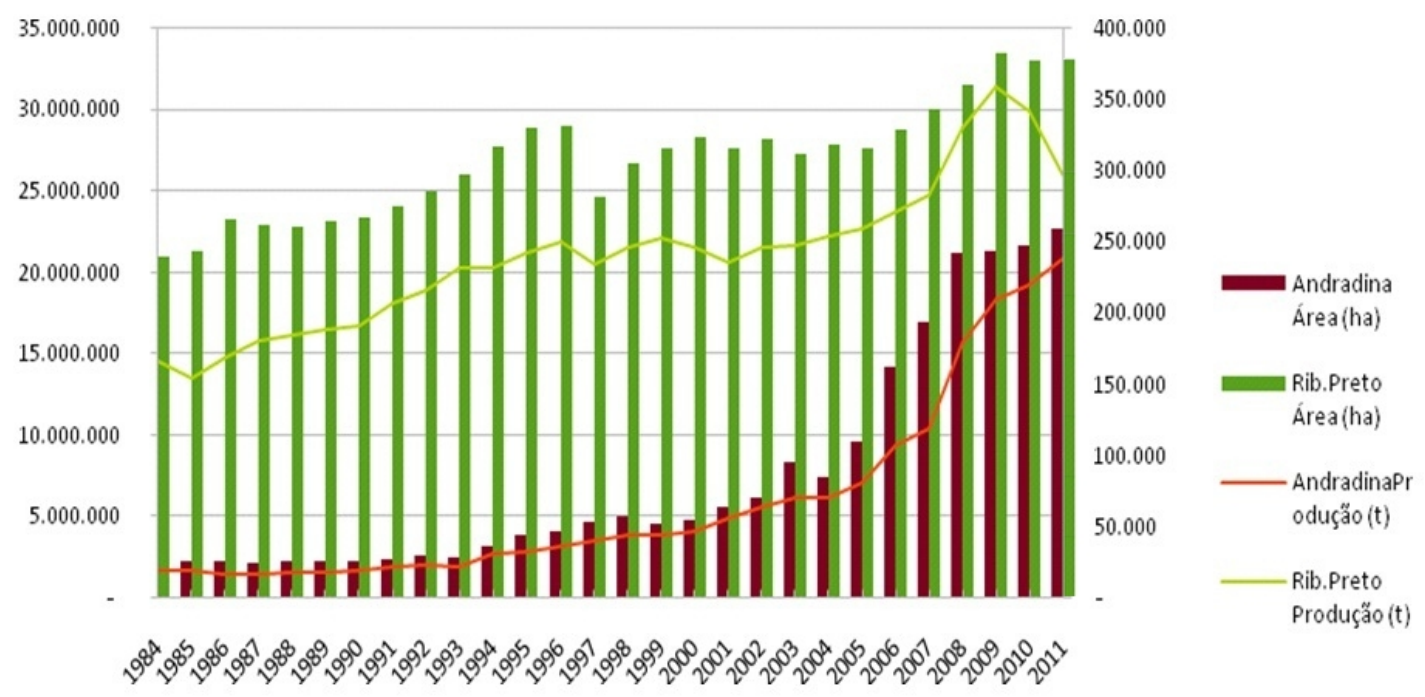

Fonte: IEA; SIDRA-IBGE, 2012. (Organização: Natália Freire Bellentani)

Neste sentido, os grupos produtores de açúcar e álcool mantêm-se atrelados, por exemplo, ao Banco Nacional de Desenvolvimento Econômico e Social (BNDES), por meio de operações diretas de investimento público ao setor.

Posto isso, é interessante lembrar, como apontado anteriormente, que historicamente estes investimentos se dão, seja por meio de programas específicos de incentivo, como foi o caso do Proálcool (programa criado em 1975 e que incentivou a produção de etanol à base de cana-de-açúcar), seja nos dias atuais, com as linhas específicas de crédito vinculadas ao BNDES, que tratam desde aquisição de crédito para compra de máquinas até recursos para o preparo do solo e plantio.

Para fortalecer o entendimento sobre este setor e seu alastramento sobre o campo paulista, parte-se agora para uma demonstração da área total agrícola, área cultivada com cana-de-açúcar e percentual de cana-de-açúcar em relação à área total de cinco 
municípios mais significativos para cada EDR escolhido, tanto para as áreas que produzem cana-de-açúcar a mais tempo, como para as áreas de produção mais recente, respectivamente.

Nas tabelas 07 e 08 e nos gráficos 05 e 06 pode-se verificar como esta evolução que ocorre sob a égide do capital monopolista, vem determinando que a circulação das mercadorias do setor sucroenergético esteja subordinada à produção destas agroindústrias.

Tabela 07: Área total agrícola, área cultivada com cana-de-açúcar e percentual de canade-açúcar em relação a área total, entre os anos 1997 e 2008, nos municípios de Piracicaba, Ribeirão Preto, Jaú, Jaboticabal e Araras.

\begin{tabular}{lc|c|c|c|c|c}
\hline & \multicolumn{2}{c}{$1996 / 1997$} & \multicolumn{3}{c}{$\mathbf{2 0 0 7 / 0 8}$} \\
\cline { 2 - 8 } MUNICÍPIOS & $\begin{array}{c}\text { Área total } \\
\text { (ha) }\end{array}$ & $\begin{array}{c}\text { Cana-de- } \\
\text { açúcar } \\
\text { (ha) }\end{array}$ & $\begin{array}{c}\text { Percentual } \\
\text { Cana-de- } \\
\text { açúcar (\%) }\end{array}$ & $\begin{array}{c}\text { Área total } \\
\text { (ha) }\end{array}$ & $\begin{array}{c}\text { cana-de- } \\
\text { Ccúcar } \\
\text { (ha) }\end{array}$ & $\begin{array}{c}\text { Percentual } \\
\text { Cana-de- } \\
\text { açúcar } \\
\text { (\%) }\end{array}$ \\
\hline Piracicaba & $118.341,00$ & $50.981,80$ & 43,08 & $115.940,4$ & $54.685,4$ & 47,11 \\
\hline Ribeirão Preto & $47.900,80$ & $34.113,30$ & 71,21 & $48.405,7$ & $37.108,0$ & 76,66 \\
Jaú & $58.953,40$ & $42.815,30$ & 72,62 & $58.963,8$ & $46.454,9$ & 78,78 \\
\hline Jaboticabal & $64.496,40$ & $49.676,00$ & 77,02 & $63.397,4$ & $53.766,5$ & 84,80 \\
\hline Araras & $60.419,40$ & $30.354,90$ & 50,24 & $58.096,1$ & $31.472,2$ & 54,17 \\
\hline
\end{tabular}

Fonte: Secretaria de Agricultura e Abastecimento, CATI/IEA, Projeto LUPA (2012)

Org.: Natália Freire Bellentani

Nos municípios de Ribeirão Preto, Jaú, Jaboticabal e Araras o cultivo de canade-açúcar nos anos 1996 já ocupava mais de 50\% da área total agricultável, chegando até $77,02 \%$ no caso de Jaboticabal e apenas em Piracicaba esse valor esteve em torno de 43\%. Nos anos de 2007 todos os municípios elevaram essa percentagem, chegando no caso de Jaboticabal a $84,80 \%$ a área total agrícola ocupada com a monocultura da canade-açúcar. 
Gráfico 05: Percentual de crescimento da área total agrícola ocupada com a produção de cana-de-açúcar, entre os anos de 1997 e 2008, nos municípios de Piracicaba, Ribeirão Preto, Jaú, Jaboticabal e Araras.

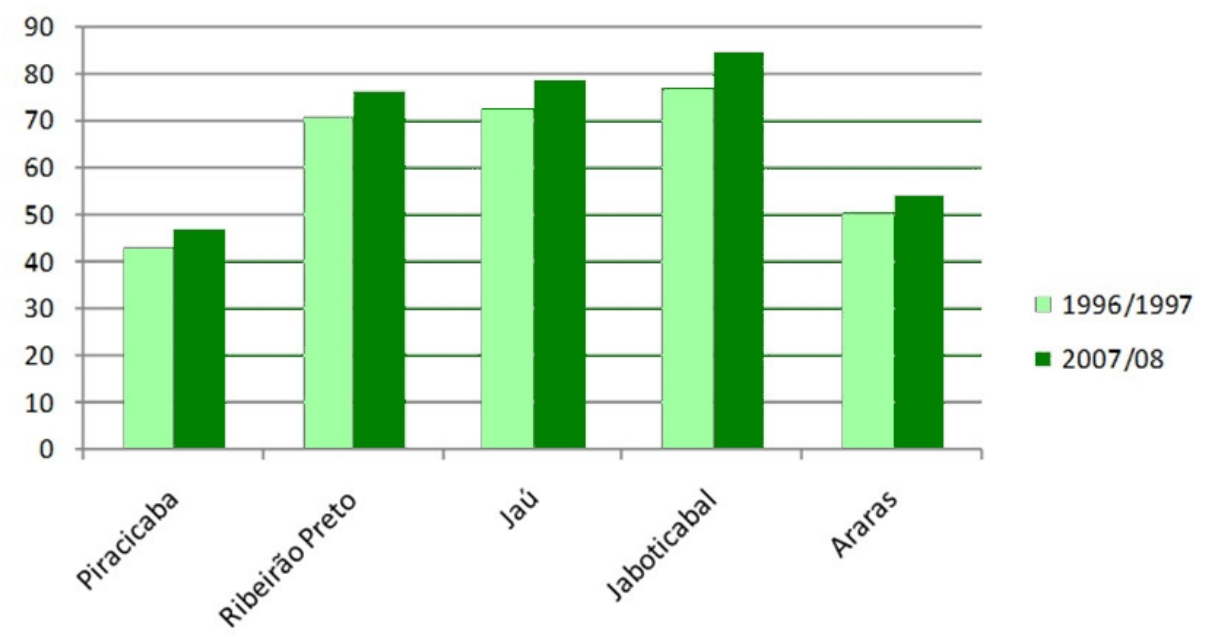

Fonte: Secretaria de Agricultura e Abastecimento, CATI/IEA, Projeto LUPA (2012) Org.: Natália Freire Bellentani

Estes municípios que produzem cana-de-açúcar a mais tempo apresentam um percentual relativamente muito alto na comparação entre a área total agrícola e a área destinada ao cultivo da cana. E como o gráfico ilustra, em todas as áreas, há um aumento do número de hectares destinados a cultura nos últimos anos.

$\mathrm{Na}$ tabela 08 é possível identificar alguns municípios que cultivam a cana-deaçúcar a menos tempo e a partir dos dados levantados verificar a relação percentual da área total agrícola e a área destinada a lavoura canavieira.

Os municípios elencados foram Lavínia, Guararapes, Rancharia, Palestina e Cafelândia, sendo cada um deles partem dos EDRs descritos anteriormente como de cultivo mais recente.

Nos anos 1996 a área destinada a monocultura da cana, em relação a área total agrícola, chegou ao máximo de $18,64 \%$ no município de Guararapes (EDR de Araçatuba). Nos anos de 2007 todos os municípios elevaram essa percentagem, 
chegando no caso de Guararapes a ultrapassar os $50 \%$ da área total agrícola ocupada com a monocultura da cana-de-açúcar.

Tabela 08: Área total agrícola, área cultivada com cana-de-açúcar e percentual de canade-açúcar em relação a área total, entre os anos 1997 e 2008, nos municípios de Lavínia, Guararapes, Rancharia, Palestina e Cafelândia.

\begin{tabular}{|c|c|c|c|c|c|c|}
\hline \multirow[b]{2}{*}{ MUNICÍPIOS } & \multicolumn{3}{|c|}{ 1996/1997 } & \multicolumn{3}{|c|}{$2007 / 08$} \\
\hline & $\begin{array}{l}\text { Área total } \\
\text { (ha) }\end{array}$ & $\begin{array}{l}\text { Cana-de- } \\
\text { açúcar } \\
\text { (ha) }\end{array}$ & $\begin{array}{l}\text { Percentual } \\
\text { Cana-de- } \\
\text { açúcar (\%) }\end{array}$ & $\begin{array}{l}\text { Área total } \\
\text { (ha) }\end{array}$ & $\begin{array}{l}\text { Cana-de- } \\
\text { açúcar } \\
\text { (ha) }\end{array}$ & $\begin{array}{l}\text { Percentual } \\
\text { Cana-de- } \\
\text { açúcar } \\
(\%)\end{array}$ \\
\hline Lavinia & $53.203,00$ & $5.615,70$ & 10,55 & $53.501,0$ & $25.557,1$ & 47,76 \\
\hline Guararapes & $89.646,90$ & $16.710,60$ & 18,64 & $92.772,8$ & $46.561,1$ & 50,18 \\
\hline Rancharia & $152.096,60$ & $5.255,80$ & 3,45 & $150.885,9$ & $22.300,4$ & 14,77 \\
\hline Palestina & $67.419,90$ & $1.672,00$ & 2,47 & $67.120,9$ & $21.808,6$ & 32,49 \\
\hline Cafelândia & $83.704,70$ & $2.936,90$ & 3,50 & $85.767,8$ & $29.616,7$ & 34,53 \\
\hline
\end{tabular}

Fonte: Secretaria de Agricultura e Abastecimento, CATI/IEA, Projeto LUPA (2012)

No gráfico 06 pode-se verificar o crescimento da área cultivada com cana-deaçúcar nos últimos anos. A diferença em todos os municípios listados entre os anos de 1996 e 2007 é significativamente elevada.

Gráfico 06: Percentual de crescimento da área total agrícola ocupada com a produção de cana-de-açúcar, entre os anos de 1997 e 2008, nos municípios de Lavínia, Guararapes, Rancharia, Palestina e Cafelândia

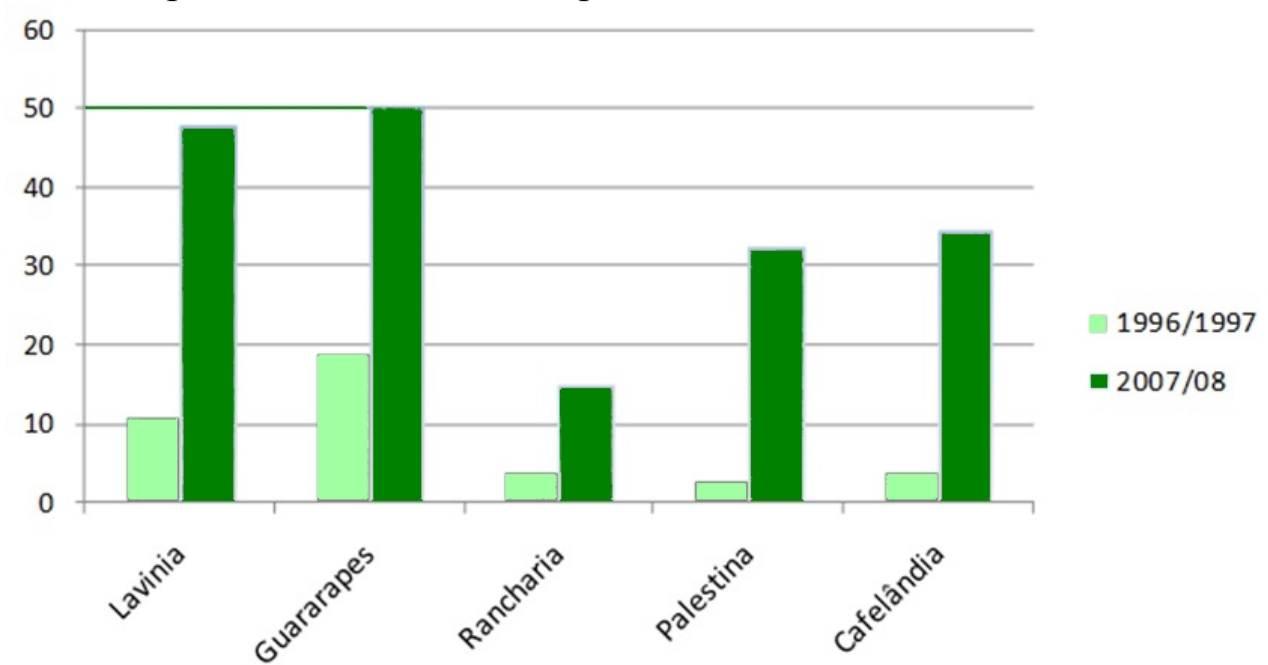

Fonte: Secretaria de Agricultura e Abastecimento, CATI/IEA, Projeto LUPA (2012) Org.: Natália Freire Bellentani 
Como se pode observar para os municípios dos EDRs de cultivo mais recente é possível inferir que o crescimento da área cultivada com cana-de-açúcar e o percentual de cana-de-açúcar em relação à área total agrícola se deram de maneira muito intensa nos últimos anos. E nas áreas que cultivam a cultura a mais tempo, ela continua expandindo o número de hectares cultivado para a produção do açúcar, do etanol e também de energia produzida a partir do bagaço da cana.

As agroindústrias canavieiras cada vez mais negociam o aumento das vendas dessas mercadorias e para tanto precisam aumentar a área de cultivo de cana-de-açúcar. Seja em área própria ou de terceiros. Neste processo são os grupos empresariais monopolistas os protagonistas nessa fase iniciada com a liberalização completa do setor, na década de 1990, consolidando a concentração econômica e territorial como características edificantes para o desenvolvimento do setor sucroenergético. 


\section{IV - Os grupos monopolistas territorializados no setor sucroenergético}

Como já afirmado anteriormente, a formação dos grupos econômicos monopolistas territorializados ocorreu a partir da década de 1990 com a desregulamentação do setor. Assim, segundo Oliveira (2014), o setor sucroenergético passou a conhecer a partir da década de 1990, três processos simultâneos, formando uma nova tríade: concentração econômica produto da integração vertical e, sobretudo, da horizontal ou "cartelização técnica", mundialização e concentração territorial. (OLIVEIRA, 2014, Obra Inédita).

Formaram-se assim, em termos técnicos, dois tipos de grupos econômicos. Aqueles que investiram na integração vertical aumentando a capacidade produtiva de suas plantas agroindustriais. É possível que os grupos São Martinho, Colorado e Raízen - Da Barra que processaram na safra de 2012/2013 mais de 7 milhões de toneladas de cana, sejam os principais exemplos que possuem essa característica. Porém, a maioria dos demais grupos foi sendo formada a partir da integração horizontal complementados pela concentração territorial, através das fusões territoriais monopolísticas, e às vezes, através também da mundialização. Estes grupos articularam duas ou mais plantas agroindustriais através de associações, fusões ou compras, de modo a integrarem de forma racional o fornecimento da matéria-prima para cada uma das plantas agroindustriais. Além desta especificidade técnica, alteram sua constituição jurídica tornando-se empresas formadas por controladoras, de modo a disseminarem a composição do capital. Tornou-se comum no setor a presença de empresas holdings, administradoras de outras empresas que formam o grupo. Entre estas muitas empresas, grande parte delas são empresas de participações dos proprietários fragmentados em 
acionistas. Várias delas já chegaram ao extremo no mercado de capitais, tornando-se S/A com capitais abertos em Bolsas de Valores. A primeira e maior delas é a Cosan S/A, que abriu seu capital na BOVESPA em 2005, e, sua principal empresa de participação a Cosan Ltda. que desde 2007, possui ações na Bolsa de New York. Outras empresas do setor também já seguiram o mesmo caminho: São Martinho S/A (2007), Tereos Internacional S/A (2007) e a Biosev S/A em (2013). Várias mundializaram-se formando joint ventures com grupos mundiais, como por exemplos: Raízen Energia S/A (Cosan S/A 51\% e Shell 49\%); Odebrecht Agroindustrial S/A (Odebrecht S/A 53\%, BNDESPar 14,4\%, Brenco (Brazilian Renewable Energy Company) 16,5\% (Ashmore 13,1\%, Tarpon 2,4\% e 1,0\% outros), Sojitz Corporation 16,1\%); Grupo Bertin (Bertin S/A $70 \%$ e 30\% da Infinity Bio Energy formada pelo Kidd \& Company, Och-Ziff e o Merryl Linch). Outros grupos nacionais tornaram-se minoritários nas fusões/associações com empresas mundiais, como por exemplo: Biosev S/A tem a Santa Elisa Participações S/A com 5,85\% de seu capital; e, a Bunge Limited que tem como sócio a Moema Participações S/A que ficou com 9\% do capital mundial da multinacional, além da empresa atuar em parceria (20\%) com a Itochu Corporation nas unidades de Santa Juliana, em Minas Gerais, e de Pedro Afonso, em Tocantins.

Assim, o Brasil contava na safra 2012/2013, com aproximadamente 85 grupos monopolistas territorializados ${ }^{19}$ produzindo açúcar, etanol, geração de energia e subprodutos derivados da cana-de-açúcar. Deste total, há 45 grupos distribuídos no interior do Estado de São Paulo (Abengoa; Aralco; Atalla; Aurélio Nardini; Balbo; Batatais; Bazan, Bertolo; Biosev; Bunge; Cargill; Clealco; Cocal; Colombo; Colorado; Comanche, Diné; Extra Bioenergia; Furlan; Tereos Internacional; Iracema (Dário); Irmãos Toniello; Itaiquara; Lincoln Junqueira; Moreno; Noble Group; Odebrecht; Pedra

\footnotetext{
${ }^{19}$ Conforme Anuário da Cana de 2013, UNICA, UDOP etc.
} 
Agroindustrial; Pitangueiras; Raízen (Cosan); Renuka do Brasil; Ruette; Santa Adélia; Santa Isabel; São Martinho; Tavares de Almeida; Titoto; Toledo; Tonon; Umoe Bioenergy; Unialco; USJ (União São João); Virgolino de Oliveira; e Zilor). Essas empresas que atuam com grupos monopolistas territorializados contam com 125 plantas agroindustriais em diferentes regiões do Estado de São Paulo.

Entretanto, é necessário assinalar que o total das unidades agroindustriais (usinas/destilarias) instaladas no Estado de São Paulo soma um total de 178 plantas, sendo que 141 realizam o processamento misto (açúcar e etanol) 21 unidades processam apenas etanol, uma usina produz apenas açúcar e 15 aparecem como unidades de processamento indefinido. Dos grupos destacados no Estado, a somatória de suas unidades é de 125 no total (53\%), sendo que as demais são unidades isoladas, portanto, não atuando como grupos monopolistas territorializados.

Em termos da presença do capital estrangeiro no setor sucroenergético, de acordo com levantamento realizado por OLIVEIRA (2014) o controle acionário dos grupos se mantém, majoritariamente nacional em 74,7\%. Sendo que dos 108 grupos apresentados, 17 são grupos estrangeiros, e, 2 têm capitais divididos em 50\% nacional e $50 \%$ estrangeiro. A seguir, a tabela com os 108 mais importantes produtores no país, entre os quais estão os 17 controlados pelo capital estrangeiro e, dois com participação dividida de 50\% (Tabela 09).

Entre os maiores grupos que operam no setor sucroenergético há entre os 12 principais, 5 de empresas mundiais estrangeiras: Biosev (Louis Dreifuss), Tereos, Bunge, Noble Group, e Renuka. 
Tabela 09: Grupos Produtores de Açúcar e Álcool e moagem de cana-de-açúcar no Brasil - safra 2012/2013)

\begin{tabular}{|c|c|c|c|}
\hline Ordem & UNIDADE & $\begin{array}{l}\text { CONTROLE } \\
\text { ACIONÁRIO }\end{array}$ & TON \\
\hline $1^{\circ}$ & RAÍZEN (COSAN 51\% / SHELL 49\%) & $\mathrm{BR}$ & 56.221 .000 \\
\hline $2^{\circ}$ & BIOSEV & FR & 29.536 .876 \\
\hline $3^{\circ}$ & TEREOS INTERNACIONAL S/A ${ }^{20}$ & FR & 19.738 .387 \\
\hline $4^{\circ}$ & ODEBRECHT & BR & 18.917 .647 \\
\hline $5^{\circ}$ & $\mathrm{BUNGE}^{21}$ & $\mathrm{HO}$ & 17.000 .000 \\
\hline $6^{\circ}$ & SANTA TEREZINHA & BR & 16.100 .000 \\
\hline $7^{\circ}$ & SÃO MARTINHO & BR & 13.016 .526 \\
\hline $8^{\circ}$ & NOBLE GROUP & $\mathrm{CH}$ & 10.687 .231 \\
\hline $9^{\circ}$ & ZILOR & BR & 10.020 .000 \\
\hline $10^{\circ}$ & TÉRCIO WANDERLEY & $\mathrm{BR}$ & 9.774 .697 \\
\hline $11^{\circ}$ & DELTA SUCROENERGIA & BR & 9.261 .638 \\
\hline $12^{\circ}$ & RENUKA DO BRASIL & IN & 8.583 .078 \\
\hline $13^{\circ}$ & COLORADO & $\mathrm{BR}$ & 8.492 .056 \\
\hline $14^{\circ}$ & PEDRA & BR & 8.368 .563 \\
\hline $15^{\circ}$ & MORENO & BR & 7.588 .795 \\
\hline $16^{\circ}$ & USJ & BR & 7.250 .832 \\
\hline $17^{\circ}$ & COLOMBO & BR & 7.191 .816 \\
\hline $18^{\circ}$ & CLEALCO & BR & 7.028 .841 \\
\hline $19^{\circ}$ & TONON & BR & 6.662 .270 \\
\hline $20^{\circ}$ & VALE DO VERDÃO & BR & 6.120 .932 \\
\hline $21^{\circ}$ & BERTIN (70\%) / INFINITY BIO-ENERGY (30\%) & BR & 5.738 .014 \\
\hline $22^{\circ}$ & ITAMARATI & BR & 5.489 .343 \\
\hline $23^{\circ}$ & LINCOLN JUNQUEIRA & BR & 5.015 .700 \\
\hline $24^{\circ}$ & BATATAIS & $\mathrm{BR}$ & 4.917 .863 \\
\hline $25^{\circ}$ & BP BIOFUELS & IN & 4.804 .634 \\
\hline $26^{\circ}$ & JAPUNGU & BR & 4.590 .948 \\
\hline $27^{\circ}$ & ABENGOA & ES & 4.547 .246 \\
\hline $28^{\circ}$ & IRMÃOS TONIELLO & BR & 4.542 .443 \\
\hline $29^{\circ}$ & SANTA ISABEL & BR & 4.512 .122 \\
\hline $30^{\circ}$ & ADECOAGRO & LX & 4.488 .935 \\
\hline $31^{\circ}$ & TITOTO & BR & 4.404 .850 \\
\hline $32^{\circ}$ & SJC BIOENERGIA (USJ 50\%/CARGILL 50\%) & BR/US & 4.238 .623 \\
\hline $33^{\circ}$ & CARLOS LYRA & $\mathrm{BR}$ & 4.087 .809 \\
\hline $34^{\circ}$ & ANTONIO FARIAS & BR & 3.953 .596 \\
\hline $35^{\circ}$ & PITANGUEIRAS & BR & 3.487 .959 \\
\hline $36^{\circ}$ & DINÉ & $\mathrm{BR}$ & 3.460 .549 \\
\hline $37^{\circ}$ & SANTA CRUZ $* 22$ & BR & 3.446 .078 \\
\hline $38^{\circ}$ & SÃO FERNANDO - BERTIN/BUMLAI & BR & 3.420 .698 \\
\hline $39^{\circ}$ & TOLEDO & $\mathrm{BR}$ & 3.340 .855 \\
\hline $40^{\circ}$ & JOSÉ PESSOA & BR & 3.220 .000 \\
\hline $41^{\circ}$ & AURÉLIO NARDINI & BR & 3.082 .234 \\
\hline $42^{\circ}$ & COOPCANA - SÃO CARLOS* & BR & 3.059 .393 \\
\hline $43^{\circ}$ & TAVARES DE ALMEIDA & BR & 3.020 .649 \\
\hline $44^{\circ}$ & SÃO MANOEL* & $\mathrm{BR}$ & 3.014 .418 \\
\hline $45^{\circ}$ & USJ & BR & 3.012 .209 \\
\hline $46^{\circ}$ & GUAÍRA* & BR & 2.811 .928 \\
\hline $47^{\circ}$ & SÃO JOSÉ DA ESTIVA* & $\mathrm{BR}$ & 2.811 .517 \\
\hline $48^{\circ}$ & CERRADINHO BIO* & BR & 2.770 .032 \\
\hline $49^{\circ}$ & NAOUM & BR & 2.710 .099 \\
\hline $50^{\circ}$ & SANTO ANTÔNIO & BR & 2.653 .834 \\
\hline
\end{tabular}

${ }^{20}$ A Tereos Internacional S/A tem uma parceria estratégica com a Petrobras Biocombustíveis através da empresa do grupo Açúcar Guarani S/A, onde detém 39,6\%, podendo, por contrato, chegar a $45,7 \%$.

(http://www.tereosinternacional.com.br/show.aspx?idCanal=u+Q7sscY4GtK5333Tgs9wQ==, acessado em Nov 2014.

http://siteempresas.bovespa.com.br/consbov/ArquivosExibe.asp?site=\&protocolo=243620, acessado em Nov 2014.)

21 Dados obtidos através de entrevista de seu presidente Pedro Parente (http://dinheiro.br.msn.com/artigo.aspx?cpdocumentid=253406149, acessado em 07/11/2014)

22 "O Conselho Administrativo de Defesa Econômica (Cade) aprovou operação pela qual a São Martinho adquire participação societária adicional na Santa Cruz S. para 92,14\% do capital social da empresa. O negócio foi firmado com os vendedores Luiz Ometto Participações (LOP) e demais acionistas controladores pessoas físicas da Santa Cruz. O aval do Cade está publicado no Diário Oficial da União (DOU) sem nenhuma restrição aos termos de memorando de entendimentos assinado entre as partes em maio deste ano. Pelo documento, a compra - pela São Martinho - de participação de 56,05\% do capital social da Santa Cruz, incluindo terras, custará R\$315,8 milhões, e o pagamento será feito em dez anos, corrigido pelo CDI.O acordo também prevê que a São Martinho venderá a totalidade de suas ações da Agro Pecuária Boa Vista para a LOP. A venda dessas ações, num total de $34,29 \%$, para a LOP será pelo valor de R\$ 195,9 milhões, também em dez anos e corrigido pelo CDI.Segundo fato relevante divulgado em maio, ao todo a São Martinho desembolsará R\$ 119,9 milhões pelo negócio, que ainda inclui a celebração de contrato de arrendamento de cana-de-açúcar entre a Santa Cruz e a Agro Pecuária Boa Vista por um período de 20 anos.” (Agência Estado)A Açúcar e Álcool, passando dos atuais 36,09\%. Assim, o grupo São Martinho chegou a 16.463.075 toneladas de cana moída na safra 2012/2013, passando de $7^{\circ}$ para $6^{\circ}$ lugar. 
(segue)

\begin{tabular}{|c|c|c|c|}
\hline Ordem & UNIDADE & $\begin{array}{l}\text { CONTROLE } \\
\text { ACIONÁRIO }\end{array}$ & TON \\
\hline $51^{\circ}$ & JALLES MACHADO & $\mathrm{BR}$ & 2.648 .678 \\
\hline $52^{\circ}$ & SANTA FÉ (AÇÚCAR ITAQUERÊ)* & BR & 2.629 .435 \\
\hline $53^{\circ}$ & FERRARI* & BR & 2.506 .177 \\
\hline $54^{\circ}$ & SERRA GRANDE & BR & 2.424 .916 \\
\hline $55^{\circ}$ & GOIASA* & BR & 2.389 .339 \\
\hline $56^{\circ}$ & BARRÁLCOOL* & BR & 2.351 .610 \\
\hline $57^{\circ}$ & $\begin{array}{l}\text { CMAA - VALE DO TIJUCO (50\%) - INDOAGRI } \\
\text { CINGAPURA }(50 \%)\end{array}$ & $\mathrm{BR} / \mathrm{CI}$ & 2.217 .655 \\
\hline $58^{\circ}$ & OLHO D'ÁGUA & BR & 2.175 .308 \\
\hline $59^{\circ}$ & CARGILL & US & 2.121 .031 \\
\hline $60^{\circ}$ & EQM & $\overline{B R}$ & 2.078 .387 \\
\hline $61^{\circ}$ & UNIALCO & BR & 2.076 .082 \\
\hline $62^{\circ}$ & RUETTE & BR & 2.026 .324 \\
\hline $63^{\circ}$ & BEVAP* & BR & 2.003 .295 \\
\hline $64^{\circ}$ & SANTO ÂNGELO & $\overline{B R}$ & 1.992 .047 \\
\hline $65^{\circ}$ & COPRODIA* & BR & 1.991 .465 \\
\hline $66^{\circ}$ & SABARALCOOL & BR & 1.983 .382 \\
\hline $67^{\circ}$ & SANTA HELENA - MS* & $\overline{B R}$ & 1.980 .000 \\
\hline $68^{\circ}$ & UMOE BIOENERGY - SANDOVALINA & $\mathrm{NO}$ & 1.900 .000 \\
\hline $69^{\circ}$ & CAROLO - NOSSA SRA. (PONTAL)* & BR & 1.898 .727 \\
\hline $70^{\circ}$ & SÃO DOMINGOS* & BR & 1.885 .673 \\
\hline $71^{\circ}$ & JACAREZINHO* & BR & 1.855 .872 \\
\hline $72^{\circ}$ & ESTER* & BR & 1.786 .795 \\
\hline $73^{\circ}$ & ARAPORÁ (EX-ALVORADA)* & $\overline{\mathrm{BR}}$ & 1.783 .001 \\
\hline $74^{\circ}$ & OLIVAL TENÓRIO & BR & 1.678 .496 \\
\hline $75^{\circ}$ & CAMPESTRE* & BR & 1.583 .780 \\
\hline $76^{\circ}$ & IPOJUCA & $\overline{B R}$ & 1.555 .512 \\
\hline $77^{\circ}$ & DESTIL - ITAJOBI* & BR & 1.550 .000 \\
\hline $78^{\circ}$ & ANDRADE & BR & 1.526 .401 \\
\hline $79^{\circ}$ & CRUANGI & BR & 1.493 .986 \\
\hline $80^{\circ}$ & JB & BR & 1.489 .032 \\
\hline $81^{\circ}$ & OCBIO (DELLA COLETTA)* & BR & 1.473 .374 \\
\hline $82^{\circ}$ & ÁGUA BONITA* & $\overline{B R}$ & 1.412 .515 \\
\hline $83^{\circ}$ & CIA. MELHORAMENTOS NORTE PARANÁ & BR & 1.405 .063 \\
\hline $84^{\circ}$ & COOPERB & BR & 1.376 .227 \\
\hline $85^{\circ}$ & ALVORADA DO BEBEDOURO & $\overline{B R}$ & 1.362 .747 \\
\hline $86^{\circ}$ & SANTA MARIA - J. PILON* & BR & 1.361 .539 \\
\hline $87^{\circ}$ & SINIMBU* & BR & 1.305 .470 \\
\hline $88^{\circ}$ & CLEAN ENERGY BRAZIL - CEB & IN & 1.304 .698 \\
\hline $89^{\circ}$ & AGROVALE (MANDACARU)* & BR & 1.265 .991 \\
\hline $90^{\circ}$ & RIO VERMELHO - GLENCORE & SU & 1.256 .452 \\
\hline $91^{\circ}$ & TRIUNFO* & BR & 1.226 .833 \\
\hline $92^{\circ}$ & BIOENERGIA* & BR & 1.210 .905 \\
\hline $93^{\circ}$ & SONORA ESTÂNCIA* & IT & 1.154 .559 \\
\hline $94^{\circ}$ & ROÇADINHO* & BR & 1.140 .795 \\
\hline $95^{\circ}$ & JOÃO SANTOS & BR & 1.130 .198 \\
\hline $96^{\circ}$ & JOÃO LYRA & BR & 1.110 .392 \\
\hline $97^{\circ}$ & CAÇÚ* & BR & 1.093 .811 \\
\hline $98^{\circ}$ & DASA* & BR & 1.089 .294 \\
\hline $99^{\circ}$ & COOPERVAL* & BR & 1.082 .837 \\
\hline $100^{\circ}$ & WD* & BR & 1.053 .462 \\
\hline $101^{\circ}$ & AGROSERRA* & BR & 1.050 .461 \\
\hline $102^{\circ}$ & COMANCHE CLEAN ENERGY & US & 1.033 .142 \\
\hline $103^{\circ}$ & PETRIBÚ* & BR & 1.015 .739 \\
\hline $104^{\circ}$ & SÃO LUIZ & BR & 1.013 .582 \\
\hline $105^{\circ}$ & BRANCO PERES* & BR & 1.013 .065 \\
\hline $106^{\circ}$ & VALE DO PARANÁ (COLGUA) & GT/CO & 970.323 \\
\hline $107^{\circ}$ & VREC - BOM SUCESSO & US & 946.000 \\
\hline $108^{\circ}$ & ADM - ARCHER DANIELS MIDLAND COMPANY ${ }^{23}$ & US & 710.000 \\
\hline
\end{tabular}

Fonte: ANUÁRIO DA CANA, safra 2012/2013. Ribeirão Preto: PROCANA, 2013.

${ }^{23}$ Pelo ato de concentração no 08012.003914/2011-66, ocorreu a dissolução parcial de uma joint venture (constituída em 2009), a Cabrera Central Energética Açúcar e Álcool Ltda (CCEAA) formada pelo Grupo ADM - Archer Daniels Midland Campany (por meio de sua subsidiária ADM Participações Ltda) com 49\% do capital e o chamado Grupo Cabrera (por meio de sua empresa Canaã Holding Participações Ltda.) com 51\% do capital. Assim, o Grupo ADM assumiu o controle total (100\%) da joint venture CCEAA Cabrera Central Energética Açúcar e Álcool Ltda. (http://www.cade.gov.br/temp/t811201418497357.pdf, acessado em 07/11/2014). Em 2009, o Grupo ADM - Archer Daniels Midland Campany (por meio de suas subsidiárias ADM Agroinvestimentos Ltda e ADM Participações Ltda) formou uma joint venture com participação de $80 \%$ do capital da Usina de Açúcar e Álcool Jataí Ltda (Jataí) e o Grupo Cabrera (por meio de sua empresa Canaã Holding Participações Ltda.) com $20 \%$ do capital. (http://www.cade.gov.br/temp/t811201419275835.PDF, acessado em 07/11/2014) 
O mais importante a se ter em conta, neste momento, é a relação entre a organização dos grupos usineiros e a concentração econômica e territorial no setor sucroenergético e o processo de sua mundialização. Portanto é oportuno afirmar que estes grupos são compostos de forma majoritária por capital nacional, como bem destacado por Oliveira (2014):

[...] os trinta maiores grupos empresariais monopolistas foram responsáveis por $55,2 \%$ do total nacional de tonelagem de cana moída, e deste total aqueles controlados por nacionais ficaram com $38,4 \%$ e os estrangeiros ficaram com 16,8\%. Entre os grupos nacionais, aqueles que têm participação de capitais estrangeiros Raízen, Odebrecht, Bertin e USJ - moeram 6\%, sendo que, portanto, os grupos monopolistas estritamente nacionais ficaram com 32,4\%. Ou seja, há certa concentração dos grupos estrangeiros entre os maiores grupos do setor, mas, é preciso reiterar que o capital nacional controlava na safra $2012 / 13$, o total de $74,8 \%$ da tonelagem de cana moída e o capital estrangeiro 25,2\%. (OLIVEIRA, 2014, Obra Inédita)

Ademais, o Estado brasileiro, longe de estar alheio a este processo de formação e organização dos grupos, é parte fundamental do desenvolvimento dos mesmos, seja gerando condições objetivas que garantem a produção e a circulação, seja em sua participação nos processos de fusões e aquisições que, por vezes, se realizam contando com os fundos de pensão dos trabalhadores das estatais brasileiras.

O ponto fundamental é que os investimentos realizados no setor sucroenergético contam com auxilio público e no Estado de São Paulo essa realidade também se confirma como relatado anteriormente, fato que inclusive fortalece essa organização monopolística dos grupos. Trata-se, como afirmou Oliveira (2014), da expressão objetiva da territorialização do monopólio.

Na tabela e no mapa a seguir, é possível verificar, a distribuição das unidades agroindustriais pertencentes aos grupos monopolistas por todo o Estado de São Paulo. 
Tabela 10: Grupos Produtores/Unidades agroindustriais de Açúcar e Álcool e localização municipal das unidades no Estado de São Paulo (2013)

\begin{tabular}{|c|c|c|c|c|c|}
\hline $\begin{array}{l}\text { POSIÇÃO } \\
\text { RANKING } \\
\text { MOAGEM }\end{array}$ & $\begin{array}{c}\text { GRUPOS } \\
\text { PRODUTORES }\end{array}$ & $\begin{array}{c}\text { UNIDADES } \\
\text { AGROINDUST } \\
\text { RIAIS (TOTAL } \\
\text { BRASIL) }\end{array}$ & \begin{tabular}{|c|} 
UNIDADES \\
AGROINDUSTR \\
IAIS (TOTAL \\
ESTADO SP) \\
\end{tabular} & $\begin{array}{l}\text { MUNICÍPIOS } \\
\text { (ESTADO SP) }\end{array}$ & WEBSITE \\
\hline 1 & Raízen S/A & 1 & 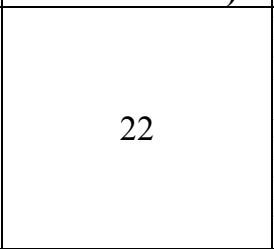 & $\begin{array}{l}\text { Barra Bonita, Bento de Abreu, Capivari, Guariba, } \\
\text { Piracicaba, Araçatuba, Jaú, Dois Córregos, } \\
\text { Andradina, Ipaussu, Igarapava, Maracaí, } \\
\text { Mirandópolis, Paraguaçu Paulista, Rafard, Rio das } \\
\text { Pedras, Elias Fausto, Ibaté, Araraquara, Tarumã e } \\
\text { Valparaíso. }\end{array}$ & www.raízen.com \\
\hline 2 & Biosev S/A & 12 & 6 & $\begin{array}{l}\text { Colômbia, Leme, Jardinópolis, Morro Agudo e } \\
\text { Sertãozinho }\end{array}$ & www.biosev.com.br \\
\hline 3 & $\begin{array}{l}\text { Tereos Internacional } \\
\text { S/A }\end{array}$ & 7 & 7 & $\begin{array}{l}\text { Pitangueiras, Olímpia, Guaíra, Colina, Severina, } \\
\text { Tanabi e Guaraci }\end{array}$ & www.aguarani.com.br \\
\hline 4 & Odebrecht & 9 & 2 & Teodoro Sampaio e Mirante do Paranapanema & www.odebrechtagroindustrial.com \\
\hline 5 & Clealco & 3 & 3 & Clementina, Queiroz e Tupã & www.clealco.com.br \\
\hline 6 & São Martinho & 4 & 2 & Pradópolis e Iracemápolis & www.saomartinho.ind.br \\
\hline 7 & Noble Group & 4 & 4 & $\begin{array}{l}\text { Catanduva, Meridiano, Potirendaba, Sebastianópolis } \\
\text { do Sul }\end{array}$ & www.thisisnoble.com \\
\hline 8 & Zilor & 3 & 3 & Lençóis Paulista, Quatá, Macatuba & www.zilloren.com.br \\
\hline 11 & Renuka do Brasil & 4 & 2 & Promissão e Brejo Alegre & www.renukabrasil.com.br \\
\hline 12 & Colorado & 2 & 1 & Guaíra & www.colorado.com.br \\
\hline 13 & Pedra Agroindustrial & 4 & 4 & $\begin{array}{l}\text { Buritizal, Santa Rosa do Viterbo, Nova } \\
\text { Independência e Serrana }\end{array}$ & www.pedraagroindustrial.com.br \\
\hline 14 & Moreno & 3 & 3 & Planalto, Luís Antônio e Monte Aprazível & www.usinamoreno.com.br \\
\hline 15 & Colombo & 3 & 3 & Ariranha, Palestina e Santa Albertina & www.acucarcaravelas.com.br \\
\hline 16 & Tonon & 3 & 2 & Brotas e Bocaina & www.paraisobioenergia.com.br \\
\hline 20 & Batatais & 2 & 2 & Batatais e Lins & www.usinabatatais.com.br \\
\hline 23 & Abengoa & 2 & 2 & São João da Boa Vista e Pirassununga & www.abengoabioenergy.com \\
\hline 24 & Irmãos Toniello & 3 & 3 & Sertãozinho, Pitangueiras e Castilho & - \\
\hline 25 & Santa Isabel & 2 & 2 & Novo Horizonte e Mendonça & www.usinasantaisabel.com.br \\
\hline 27 & Titoto & 3 & 3 & Descalvado, Iacanga, Mococa & www.usinaipiranga.com.br \\
\hline 30 & Carlos Lyra & 5 & 1 & Pauliceia & www.carloslyra.com.br \\
\hline
\end{tabular}




\begin{tabular}{|c|c|c|c|c|c|}
\hline $\begin{array}{l}\text { POSIÇÃO } \\
\text { RANKING } \\
\text { MOAGEM }\end{array}$ & GRUPOS PRODUTORES & \begin{tabular}{|c|} 
UNIDADES \\
AGROINDUSTRIA \\
IS (TOTAL \\
BRASIL) \\
\end{tabular} & \begin{tabular}{|c|} 
UNIDADES \\
AGROINDUSTRIAIS \\
(TOTAL ESTADO \\
SP)
\end{tabular} & $\begin{array}{l}\text { MUNICÍPIOS } \\
\text { (ESTADO SP) }\end{array}$ & WEBSITE \\
\hline 31 & Antonio Farias & 7 & 1 & Rio das Pedras & www.grupofarias.com.br \\
\hline 32 & Pitangueiras & 2 & 1 & Pitangueiras & www.pitaa.com.br \\
\hline 33 & Diné & 3 & 2 & Araraquara e Sta Rita do Passa Quatro & www.usinasantarita.com.br \\
\hline 36 & Toledo & 4 & 1 & Borá & www.grupotoledo.com.br \\
\hline 38 & Aurélio Nardini & 2 & 1 & Vista Alegre do Alto & www.nardini.ind.br \\
\hline 40 & Tavares de Almeida & 2 & 2 & Cerqueira César e Itapetininga & - \\
\hline 41 & São Manoel & 1 & 1 & São Manuel & www.saomaoel.cm.br \\
\hline 42 & USJ & 1 & 1 & Araras & www.usj.com.br \\
\hline 43 & Guaíra & 1 & 1 & Guaíra & www.uag.com.br \\
\hline 44 & São José da Estiva & 1 & 1 & Novo Horizonte & www.usinaestiva.com.br \\
\hline 49 & Santa Fé & 1 & 1 & Nova Europa & www.usinasantafe.com.br \\
\hline 50 & Ferrari & 1 & 1 & Pirassununga & www.usinaferrari.com.br \\
\hline 56 & Cargill & 1 & 1 & Patrocínio Paulista & www.cargill.com.br \\
\hline 58 & Unialco & 2 & 1 & Guararapes & www.unialco.com.br \\
\hline 59 & Ruette & 2 & 2 & Paraíso e Ubarana & www.usinaruette.com.br \\
\hline$*$ & Bunge & 9 & 4 & Pedranópolis, Pontes Gestal, Orindiúva e Ouroeste & http://www.bunge.com.br/ \\
\hline$*$ & Cocal & 2 & 2 & Narandiba e Paraguaçu Paulista & www.cocal.com.br \\
\hline$*$ & $\begin{array}{l}\text { Comanche Clean } \\
\text { Energy }\end{array}$ & 4 & 2 & Canitar e Tatuí & www.comanche.com.br \\
\hline$*$ & Furlan & 2 & 2 & Sta Barbara d'Oeste e Avaré & www.usinafurlan.com.br \\
\hline$*$ & Iracema (Dário) & 3 & 3 & Itaí, Riversul e Taquarituba & www.industriairacema.com.br \\
\hline$*$ & Itaiquara & 2 & 1 & Tapiratiba & www.itaiquara.com.br \\
\hline * & José Pessoa & 4 & 1 & Icém & - \\
\hline$*$ & Lincoln Junqueira & 5 & 2 & São Joaquim da Barra e Presidente Prudente & www.altoalegre.com.br \\
\hline$*$ & Santa Adélia & 3 & 3 & Jaboticabal, Pereira Barreto e Sud Menucci & www.usinasantaadelia.com.br \\
\hline$*$ & Aralco & 5 & 5 & $\begin{array}{l}\text { Araçatuba, Buritama, General Salgado, Santo } \\
\text { Antônio do Aracanguá e Auriflama }\end{array}$ & www.aralco.com.br \\
\hline$*$ & Atalla & 2 & 1 & Jaú & - \\
\hline$*$ & Balbo & 2 & 2 & Sertãozinho & www.canaverde.com.br \\
\hline$*$ & Bazan & 2 & 2 & Pontal & www.usinabazan.com.br \\
\hline$*$ & Bertolo & 2 & 2 & Pirangi e Flórida Paulista & www.grupobertolo.com.br \\
\hline$*$ & Virgolino de Oliveira & 4 & 4 & Ariranha, Itapira, José Bonifácio, Monções & www. gvo.com.br \\
\hline
\end{tabular}

* não aparecem no ranking da moagem do Anuário da Cana (2013)

Fonte: ANUÁRIO DA CANA, safra 2012/2013. Ribeirão Preto: PROCANA, 2013. (Org. Natália Freire Bellentani 


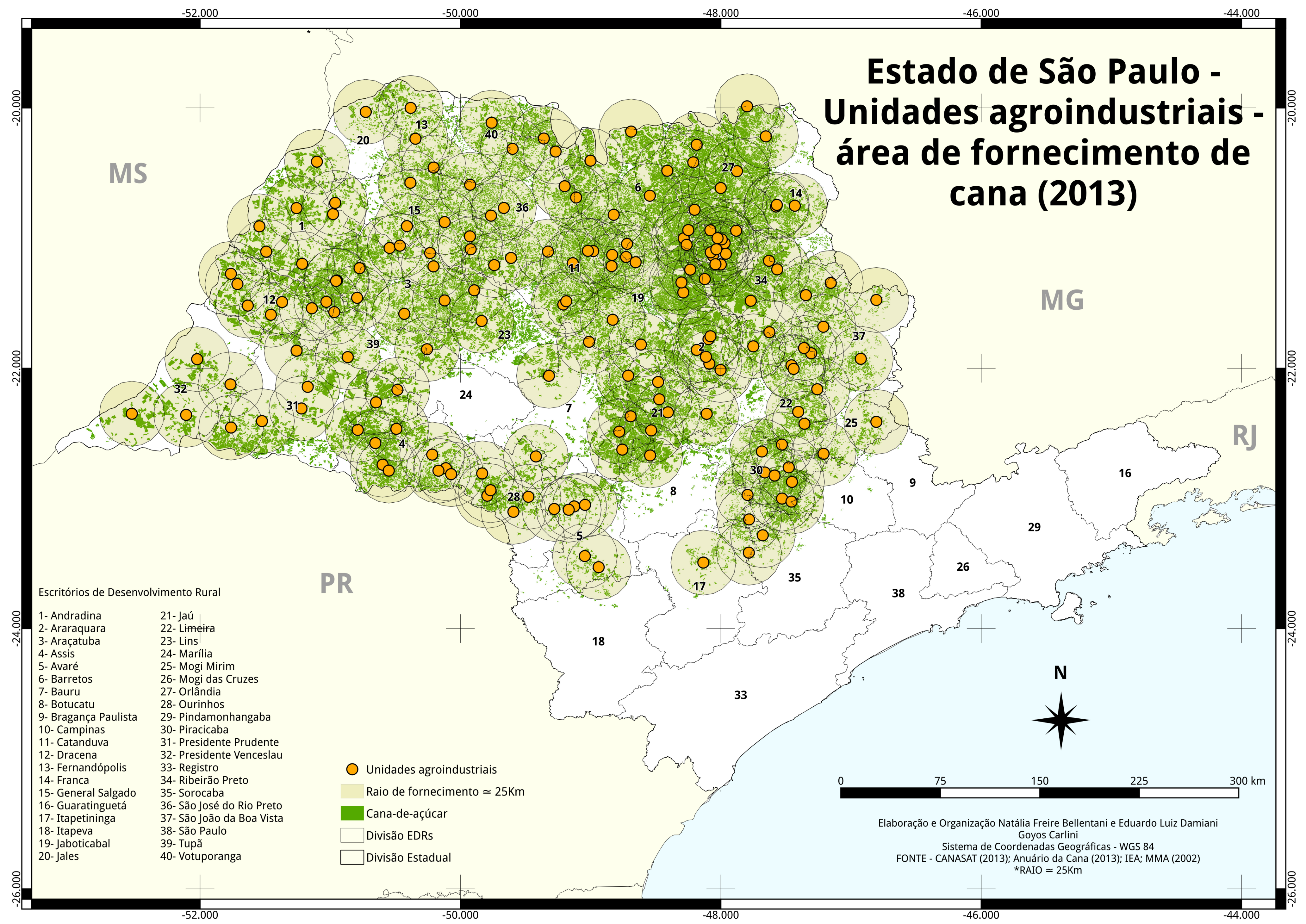


A expansão da área e da produção de cana-de-açúcar que vem sendo repetidamente anunciada em todas as estatísticas oficiais e já elencada nesta tese, ocorre de maneira muito forte no Estado de São Paulo. Como indicou Oliveira (2014) "a expansão que está ocorrendo da lavoura canavieira se dá de forma concentrada e a maior parte (52\%) da área total colhida na safra 2012/13 (8.485.000 ha) ocorreu no Estado de São Paulo. O autor afirmou ainda que São Paulo ficou com 48\% (1.272.900 ha) da expansão ocorrida entre 2005/6 e 2012/13.

[..] O estado de Goiás já é o segundo estado em área colhida de cana-deaçúcar, com 725.900 ha $(8,6 \%)$ na safra $2012 / 13$, com expansão de $19,8 \%$ (523.400 ha) do total entre 2005/6 e 2012/13. O terceiro estado produtor é Minas Gerais com 721.900 hectares (8,5\%) em 2012/13, e foi responsável por $13,8 \%$ (364.800 ha) da expansão. O quarto foi o Paraná com 610.800 ha $(7,2 \%)$ de área colhida em 2012/13, com um crescimento de 7,6\% ( 199.900 ha) no período de 2005/6 e 2012/13. O quinto foi o estado de Mato Grosso do Sul com 542.700 ha $(6,4 \%)$ de cana-de-açúcar colhida em 2012/13, e, conheceu a expansão de 15,3\% (403.600 ha) no período 2005/6 e 2012/13. [...] (OLIVEIRA, 2014, Obra Inédita)

É importante frisar que uma nova lógica está dada para a produção de canade-açúcar e neste caso a concentração vertical ${ }^{24}$ que ocorria como a única forma de organização das grandes empresas líderes do setor, agora não é mais suficiente para explicar essa expansão/diminuição de área. Visto que a concorrência e controle das propriedades privadas da terra entre as empresas foi o limite e novas formas para a apropriação dos lucros foi encontrada. A necessidade de mais fornecedores ${ }^{25}$, por

\footnotetext{
24 “É perfeitamente possível se supor que haja aumento da concentração econômica, com a junção de diferentes plantas sob a direção de uma mesma empresa ou grupo econômico. Isso pode resultar em diminuição dos custos administrativos e em aumento do poder de negociação de preços dos insumos e dos produtos e, portanto, da rentabilidade e competitividade da empresa sucroalcooleira" (BACCARIN; GEBARA; FACTORE, 2009, p. 20).

${ }^{25}$ Como visto, é necessário que a cana-de-açúcar esteja a uma distância relativamente pequena da agroindústria em que será processada. Certamente, continuará ocorrendo diminuição no custo unitário do transporte da cana-de-açúcar, bem como aumento das produtividades agrícola e industrial e, em consequência, elevação da capacidade produtiva média das agroindústrias. Contudo, não se imagina
} 
exemplo, demonstra que um novo processo territorial está em vigor, onde a lógica da competição se torna a lógica da fusão, da fusão monopolística territorial. Nesse sentido, Oliveira (2014) afirmou:

[...] entre os principais grupos empresariais monopolistas está a Raízen, produto da fusão entre a Cosan S/A e a Shell. A constituição da Cosan, um dos primeiros grupos empresariais monopolistas do setor, deu origem a um tipo específico de monopólio que atua sob a forma de holding, ou seja, sem concentrar verticalmente a atividade produtiva em uma ou algumas plantas industriais, e consequentemente, ter o aumento da produtividade industrial calcada no aumento da escala de produção e, portanto, na concentração do processo produtivo industrial. A empresa atua através de aquisições, fusões e arrendamentos para, principalmente, definir fixação de preços, divisão de mercados de atuação, etc. Elimina assim, a concorrência e aumenta os preços dos produtos, e, consequentemente os lucros. Ou seja, ocorre a concentração horizontal, ou uma espécie de "cartelização técnica". Diferente pois, do que estava ocorrendo no setor até a década de 90 , quando as unidades de produção caminharam na direção da concentração vertical. (OLIVEIRA, 2014, Obra Inédita)

Esses grupos empresariais monopolistas estão distribuídos por todo Estado de

São Paulo e importa frisar que todos têm como objetivo central vender sua mercadoria por toda parte, por todo planeta. Algumas unidades agroindustriais de determinados grupos já expressam objetivamente este processo de fusão territorial monopolística, como se verificará a seguir.

Diante desse quadro, agora serão apresentados os dados referentes a quantidade de cana moída por cada grupo, paralelamente a quantidade de açúcar e etanol produzidos, respectivamente. A Bunge Limited não aparecerá nas tabelas porque a empresa de economia fechada, não divulga os dados sobre sua produção.

que isso resulte em significativo aumento da concentração técnica no setor que, por exemplo, levasse à diminuição do número de agroindústrias no Brasil, de próximo a quatro centenas para uma centena ou menos. Pelo contrário, dependendo da evolução do mercado de açúcar e do álcool, o mais provável é que o número de agroindústrias continue aumentando (BACCARIN; GEBARA; FACTORE, 2009, p. 20). 
Tabela 11: Ranking da moagem (t) dos 10 primeiros Grupos Produtores de Açúcar e Etanol e suas Unidades Agroindústrias no Estado de São Paulo - Anuário da Cana (2013)

Ranking da moagem (t) no Estado de São Paulo - 2013

\begin{tabular}{|c|c|c|c|}
\hline Grupo & $\begin{array}{l}\text { Moagem } \\
(\mathbf{t})\end{array}$ & $\begin{array}{l}\text { Unidades } \\
\text { Industriais }\end{array}$ & Municípios \\
\hline $1^{\circ}$ Raízen S/A & 53.464 .007 & $\begin{array}{l}\text { Araraquara; Barra; } \\
\text { Benálcool; Bom Retiro; } \\
\text { Bonfim ; Costa Pinto; } \\
\text { Destivale; Diamante; Dois } \\
\text { Córregos; Gasa; Ipaussu; } \\
\text { Junqueira; Maracaí; } \\
\text { Mundial; Paraguaçu; } \\
\text { Rafard; Santa Helena; S. } \\
\text { Francisco; Serra Tamoio; } \\
\text { Tarumã; Univalem }\end{array}$ & $\begin{array}{l}\text { Barra Bonita, Bento de Abreu, } \\
\text { Capivari, Guariba, Piracicaba, } \\
\text { Araçatuba, Jaú, Dois Córregos, } \\
\text { Andradina, Ipaussu, Igarapava, } \\
\text { Maracaí, Mirandópolis, } \\
\text { Paraguaçu Paulista, Rafard, Rio } \\
\text { das Pedras, Elias Fausto, Ibaté, } \\
\text { Araraquara, Tarumã e } \\
\text { Valparaíso. }\end{array}$ \\
\hline $2^{\circ}$ Biosev S/A & 29.536 .876 & $\begin{array}{l}\text { Continental; Cresciumal; } \\
\text { Jardest; MB; Santa Elisa; } \\
\text { Vale do Rosário }\end{array}$ & $\begin{array}{l}\text { Colômbia, Leme, Jardinópolis, } \\
\text { Morro Agudo e Sertãozinho }\end{array}$ \\
\hline $\begin{array}{l}3^{\circ} \text { Tereos } \\
\text { Internacional } \\
\mathrm{S} / \mathrm{A}\end{array}$ & 19.738 .387 & $\begin{array}{l}\text { Andrade; Cruz Alta; } \\
\text { Mandu; São José; Severina; } \\
\text { Tanabi; } \\
\text { Vertente }\end{array}$ & $\begin{array}{l}\text { Pitangueiras, Olímpia, Guaíra, } \\
\text { Colina, Severina, Tanabi, } \\
\text { Guaraci }\end{array}$ \\
\hline $4^{\circ}$ Odebrecht & 18.917 .647 & $\begin{array}{l}\text { Alcídia e Mirante do } \\
\text { Paranapanema }\end{array}$ & Teodoro Sampaio \\
\hline $5^{\circ}$ Clealco & 14.057 .683 & Clementina; Queiroz; Tupã & Clementina, Queiroz e Tupã \\
\hline $6^{\circ}$ São Martinho & 13.016 .526 & São Martinho; Iracema & Pradópolis e Iracemápolis \\
\hline $7^{\circ}$ Noble Group & 10.687 .231 & $\begin{array}{l}\text { Catanduva; Meridiano; } \\
\text { Potirendaba; } \\
\text { Sebastianópolis }\end{array}$ & $\begin{array}{l}\text { Catanduva, Meridiano, } \\
\text { Potirendaba e Sebastianópolis } \\
\text { do Sul }\end{array}$ \\
\hline $8^{\circ}$ Zillor & 10.020 .000 & $\begin{array}{l}\text { Barra Grande; Quatá; São } \\
\text { José }\end{array}$ & $\begin{array}{l}\text { Lençóis Paulista, Quatá e } \\
\text { Macatuba }\end{array}$ \\
\hline $\begin{array}{l}9^{\circ} \text { Renuka do } \\
\text { Brasil }\end{array}$ & 8.583 .078 & Equipav; Revati & Promissão e Brejo Alegre \\
\hline $10^{\circ}$ Colorado & 8.492 .056 & Colorado & Guaíra \\
\hline
\end{tabular}

Fonte: ANUÁRIO DA CANA, safra 2012/2013. Ribeirão Preto: PROCANA, 2013. (Org. Natália Freire Bellentani) 
Tabela 12: Ranking dos 10 primeiros Grupos Produtores de Açúcar e suas Unidades Agroindustriais no Estado de São Paulo - Anuário da Cana (2013)

Ranking do Açúcar no Estado de São Paulo - 2013

\begin{tabular}{|c|c|c|c|}
\hline Grupo & Toneladas & $\begin{array}{c}\text { Unidades } \\
\text { agroindustriais }\end{array}$ & Municípios \\
\hline $1^{\circ}$ Raízen S/A & $4,162,000$ & $\begin{array}{l}\text { Araraquara; Barra; } \\
\text { Benálcool; Bom Retiro; } \\
\text { Bonfim; Costa Pinto; } \\
\text { Destivale; Diamante; } \\
\text { Dois Córregos; Gasa; } \\
\text { Ipaussu; Junqueira; } \\
\text { Maracaí; Mundial; } \\
\text { Paraguaçu; Rafard; } \\
\text { Santa Helena; S. } \\
\text { Francisco; Serra Tamoio; } \\
\text { Tarumã; Univalem }\end{array}$ & $\begin{array}{l}\text { Barra Bonita, Bento de } \\
\text { Abreu, Capivari, Guariba, } \\
\text { Piracicaba, Araçatuba, Jaú, } \\
\text { Dois Córregos, Andradina, } \\
\text { Ipaussu, Igarapava, Maracaí, } \\
\text { Mirandópolis, Paraguaçu } \\
\text { Paulista, Rafard, Rio das } \\
\text { Pedras, Elias Fausto, Ibaté, } \\
\text { Araraquara, Tarumã e } \\
\text { Valparaíso. }\end{array}$ \\
\hline $2^{\circ}$ Biosev S/A & $2,135,974$ & $\begin{array}{l}\text { Continental } \\
\text { Cresciumal } \\
\text { Jardest } \\
\text { MB } \\
\text { Santa Elisa } \\
\text { Vale do Rosário }\end{array}$ & $\begin{array}{l}\text { Colômbia } \\
\text { Leme } \\
\text { Jardinópolis } \\
\text { Morro Agudo } \\
\text { Sertãozinho }\end{array}$ \\
\hline $\begin{array}{l}3^{\circ} \text { Tereos } \\
\text { Internacional } \\
\mathrm{S} / \mathrm{A}\end{array}$ & $1,613,112$ & $\begin{array}{l}\text { Andrade } \\
\text { Cruz Alta } \\
\text { Mandu } \\
\text { São José } \\
\text { Severina } \\
\text { Tanabi } \\
\text { Vertente }\end{array}$ & $\begin{array}{l}\text { Pitangueiras } \\
\text { Olímpia } \\
\text { Guaíra } \\
\text { Colina } \\
\text { Severina } \\
\text { Tanabi } \\
\text { Guaraci }\end{array}$ \\
\hline $4^{\circ}$ São Martinho & 875,007 & $\begin{array}{l}\text { São Martinho } \\
\text { Iracema }\end{array}$ & $\begin{array}{l}\text { Pradópolis } \\
\text { Iracemápolis }\end{array}$ \\
\hline $5^{\circ}$ Noble Group & 840,737 & $\begin{array}{l}\text { Catanduva } \\
\text { Meridiano } \\
\text { Potirendaba } \\
\text { Sebastianópolis }\end{array}$ & $\begin{array}{l}\text { Catanduva } \\
\text { Meridiano } \\
\text { Potirendaba } \\
\text { Sebastianópolis do Sul }\end{array}$ \\
\hline $6^{\circ}$ Colorado & 668,787 & Colorado & Guaíra \\
\hline $\begin{array}{l}7^{\circ} \text { Renuka do } \\
\text { Brasil }\end{array}$ & 608,699 & $\begin{array}{l}\text { Equipav } \\
\text { Revati }\end{array}$ & $\begin{array}{l}\text { Promissão } \\
\text { Brejo Alegre }\end{array}$ \\
\hline $8^{\circ}$ Zillor & 603,370 & $\begin{array}{l}\text { Barra Grande } \\
\text { Quatá } \\
\text { São José }\end{array}$ & $\begin{array}{l}\text { Lençóis Paulista } \\
\text { Quatá } \\
\text { Macatuba }\end{array}$ \\
\hline $9^{\circ}$ Clealco & 582,150 & $\begin{array}{l}\text { Clementina } \\
\text { Queiroz } \\
\text { Tupã }\end{array}$ & $\begin{array}{l}\text { Clementina } \\
\text { Queiroz } \\
\text { Tupã }\end{array}$ \\
\hline $10^{\circ}$ Colombo & 479,149 & $\begin{array}{l}\text { Ariranha } \\
\text { Palestina } \\
\text { Santa Albertina }\end{array}$ & $\begin{array}{l}\text { Ariranha } \\
\text { Palestina } \\
\text { Santa Albertina }\end{array}$ \\
\hline
\end{tabular}

Fonte: ANUÁRIO DA CANA, safra 2012/2013. Ribeirão Preto: PROCANA, 2013. (Org. Natália Freire Bellentani) 
Tabela 13: Ranking dos 10 primeiros Grupos Produtores de Etanol e suas Unidades Agroindustriais no Estado de São Paulo - Anuário da Cana (2013)

Ranking do Etanol no Estado de São Paulo - 2013

\begin{tabular}{|c|c|c|c|}
\hline Grupo & m3 & Unidades agroindustriais & Municípios \\
\hline $1^{\circ}$ Raízen S/A & $1,903,000$ & $\begin{array}{l}\text { Araraquara; Barra; Benálcool; } \\
\text { Bom Retiro; Bonfim ; Costa } \\
\text { Pinto; Destivale; Diamante; } \\
\text { Dois Córregos; Gasa; Ipaussu; } \\
\text { Junqueira; Maracaí; Mundial; } \\
\text { Paraguaçu; Rafard; Santa } \\
\text { Helena; S. Francisco; Serra } \\
\text { Tamoio; Tarumã; Univalem }\end{array}$ & $\begin{array}{l}\text { Barra Bonita, Bento de } \\
\text { Abreu, Capivari, } \\
\text { Guariba, Piracicaba, } \\
\text { Araçatuba, Jaú, Dois } \\
\text { Córregos, Andradina, } \\
\text { Ipaussu, Igarapava, } \\
\text { Maracaí, Mirandópolis, } \\
\text { Paraguaçu Paulista, } \\
\text { Rafard, Rio das Pedras, } \\
\text { Elias Fausto, Ibaté, } \\
\text { Araraquara, Tarumã e } \\
\text { Valparaíso. }\end{array}$ \\
\hline $2^{\circ}$ Odebrecht & $1,345,293$ & Alcídia e Conquista do Pontal & $\begin{array}{l}\text { Teodoro Sampaio e } \\
\text { Mirante do } \\
\text { Paranapanema }\end{array}$ \\
\hline $3^{\circ}$ Biosev $\mathrm{S} / \mathrm{A}$ & 952,302 & $\begin{array}{l}\text { Continental } \\
\text { Cresciumal } \\
\text { Jardest } \\
\text { MB } \\
\text { Santa Elisa } \\
\text { Vale do Rosário }\end{array}$ & $\begin{array}{l}\text { Colômbia } \\
\text { Leme } \\
\text { Jardinópolis } \\
\text { Morro Agudo } \\
\text { Sertãozinho }\end{array}$ \\
\hline $\begin{array}{l}4^{\circ} \text { Tereos } \\
\text { Internacional } \mathrm{S} / \mathrm{A}\end{array}$ & 584,930 & $\begin{array}{l}\text { Andrade } \\
\text { Cruz Alta } \\
\text { Mandu } \\
\text { São José } \\
\text { Severina } \\
\text { Tanabi } \\
\text { Vertente }\end{array}$ & $\begin{array}{l}\text { Pitangueiras } \\
\text { Olímpia } \\
\text { Guaíra } \\
\text { Colina } \\
\text { Severina } \\
\text { Tanabi } \\
\text { Guaraci }\end{array}$ \\
\hline $5^{\circ}$ São Martinho & 522,050 & $\begin{array}{l}\text { São Martinho } \\
\text { Iracema }\end{array}$ & $\begin{array}{l}\text { Pradópolis } \\
\text { Iracemápolis }\end{array}$ \\
\hline $\begin{array}{l}6^{\circ} \text { Pedra } \\
\text { Agroindustrial }\end{array}$ & 511,065 & $\begin{array}{l}\text { Buriti } \\
\text { Ibirá } \\
\text { Ipê } \\
\text { Serrana }\end{array}$ & $\begin{array}{l}\text { Buritizal } \\
\text { Santa Rosa do Viterbo } \\
\text { Nova Independência } \\
\text { Serrana }\end{array}$ \\
\hline $7^{\circ}$ Zillor & 423,958 & $\begin{array}{l}\text { Barra Grande } \\
\text { Quatá } \\
\text { São José }\end{array}$ & $\begin{array}{l}\text { Lençóis Paulista } \\
\text { Quatá } \\
\text { Macatuba }\end{array}$ \\
\hline $8^{\circ}$ Moreno & 333,759 & $\begin{array}{l}\text { Coplasa } \\
\text { Luiz Antonio } \\
\text { Monte Aprazível }\end{array}$ & $\begin{array}{l}\text { Planalto } \\
\text { Luiz Antonio } \\
\text { Monte Aprazível }\end{array}$ \\
\hline $9^{\circ}$ Noble Group & 323,392 & $\begin{array}{l}\text { Catanduva } \\
\text { Meridiano } \\
\text { Potirendaba } \\
\text { Sebastianópolis }\end{array}$ & $\begin{array}{l}\text { Catanduva } \\
\text { Meridiano } \\
\text { Potirendaba } \\
\text { Sebastianópolis do Sul }\end{array}$ \\
\hline $10^{\circ}$ Colorado & 295,770 & Colorado & Guaíra \\
\hline
\end{tabular}

Fonte: ANUÁRIO DA CANA, safra 2012/2013. Ribeirão Preto: PROCANA, 2013. (Org. Natália Freire Bellentani) 
Neste momento, a tarefa central desse trabalho volta-se para a análise desses grupos monopolistas territorializados do setor sucroenergético no Estado de São Paulo. Destacam-se aqui os seguintes grupos em ordem alfabética: Abengoa Bioenergy Co.; Aralco; Balbo; Batatais; Bertolo; Biosev; Bunge; Clealco; Cocal; Colombo; Comanche; Diné; Furlan; Irmãos Toniello; Lincoln J.; Moreno; Noble; Odebrecht; Pedra Agroindustrial; Raízen Energia S/A; Renuka do Brasil; Ruette; Santa Adélia; Santa Isabel; São Martinho; Tereos International; Titoto; Tonon; Virgolino Oliveira; e Zillor. Entretanto, a sequência de apresentação será por importância econômica. (Mapa 10) 


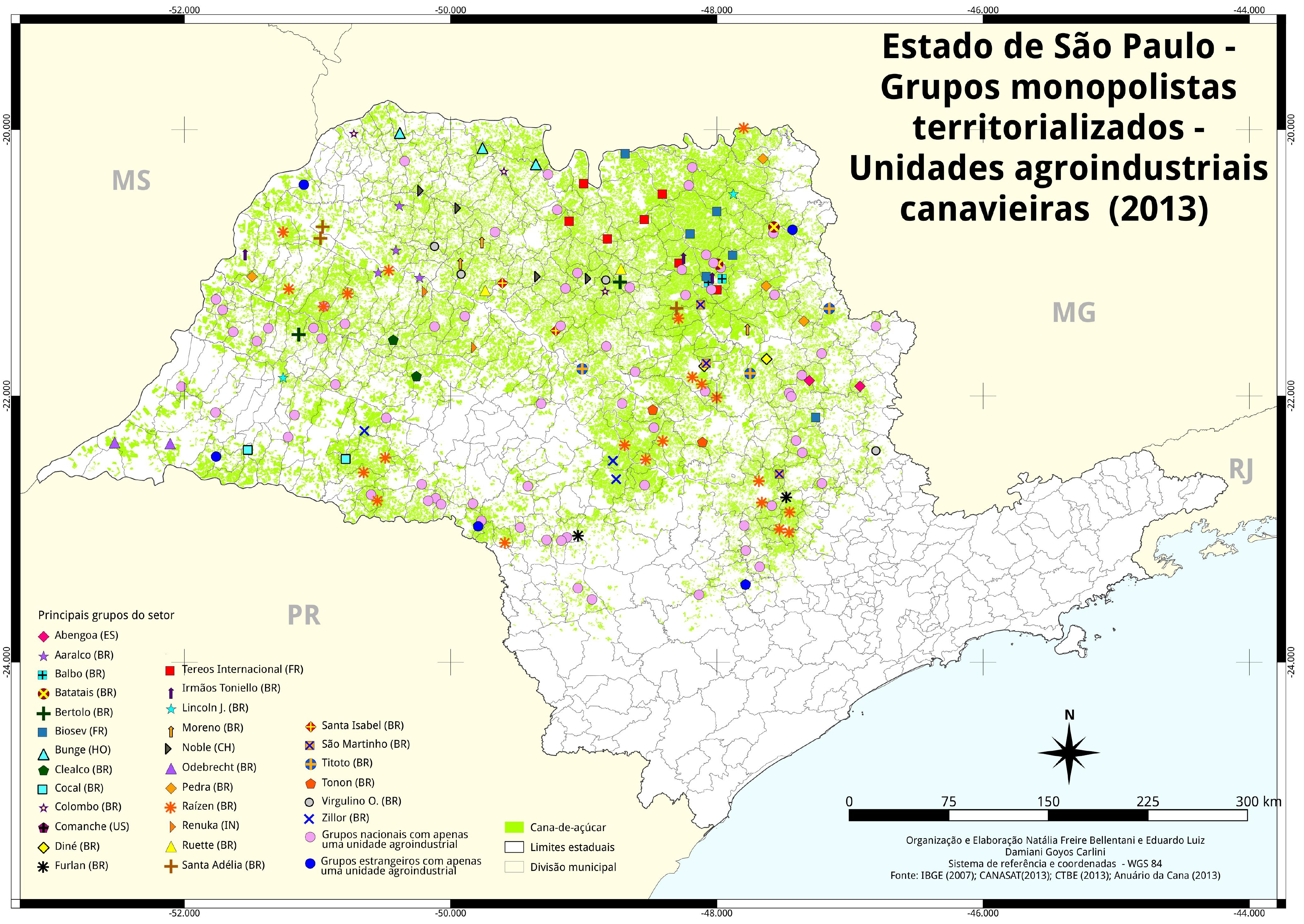




\section{RAÍZEN ENERGIA S/A}

Apresenta-se aqui o grupo Cosan/Raízen que é um dos maiores produtores e exportadores de açúcar e álcool do mundo e como noticiado pela mídia impressa, falada e meios acadêmicos, sua liderança na produção de açúcar e álcool segue inabalável.

A fusão entre a Cosan S/A e a Shell formando o grupo Raízen Energia S/A traz em si a dimensão concreta da fusão territorial monopolística. E como já foi salientado, essa fusão é reconhecida pela própria empresa que afirma ter em seus clusters a grande expressão da eficiência e sucesso do grupo: O prospecto também apresenta detalhes sobre algumas das vantagens competitividades da Raízen. A formação de clusters é uma delas, já que permite "uma maior eficiência logística e captura de sinergia nas operações das usinas ". ${ }^{26}$

O grupo Raízen Energia S/A apresenta na atualidade um faturamento de mais de R $\$ 50$ bilhões por ano ${ }^{27}$ com suas 24 usinas sucroenergéticas e 4,5 mil postos de combustíveis.

No Estado de São Paulo estão localizadas suas unidades agroindustriais nos seguintes municípios: Barra Bonita, Bento de Abreu, Capivari, Guariba, Piracicaba, Araçatuba, Jaú, Dois Córregos, Andradina, Ipaussu, Igarapava, Maracaí, Mirandópolis, Paraguaçu Paulista, Rafard, Rio das Pedras, Elias Fausto, Ibaté, Araraquara, Tarumã e Valparaíso.

\footnotetext{
${ }^{26}$ Disponível em Portal da Cana: < http://www.novacana.com/n/industria/usinas/raizen-concorrentesmercado-acucar-etanol-150914/>. Acesso em Nov. 2014.

${ }^{27}$ Vasco Dias explica que o nome Raízen, união das palavras raiz e energia, pretende reforçar, através da nova marca, a identidade brasileira. Raízen, segundo ele, é a "união de duas forças," a raiz que extrai nutrientes necessários para o crescimento da planta e a energia, necessária para todo movimento.
} 
Vale lembrar que a Cosan buscou a diversificação e aproveitou distintas oportunidades de investimento no decorrer de sua história como pode ser observado no quadro a seguir que conta a trajetória histórica deste grupo econômico que tem uma receita liquida que alcançou R $\$ 30$ bilhões no ano fiscal $2013^{28}$. (Quadro 01)

Com a transformação das unidades agroindustriais em grupos monopolísticos, uma associação dos usineiros a UNICA, passou a ser administrada por um intelectual da FEA-USP, estudioso do agronegócio. Sua presença na entidade levou a mudanças na forma de divulgação dos dados estatísticos antes feitos por usinas/destilarias. Assim, sob o manto do sigilo, tentam impedir os estudos sobre os grupos. Oliveira (2014) também tratou desta questão:

[..] Em 2013, o setor sucroenergético tinha o total 401usinas/destilarias. Entre elas, havia 294 unidades mistas produzindo açúcar e etanol, 95 destilarias dedicadas apenas ao etanol e 10 usinas voltadas somente à produção de açúcar. Essas unidades agroindustriais estavam assim localizadas: São Paulo 172 unidades; Minas Gerais 41; Goiás 34; Paraná 30; Alagoas 24; Mato Grosso do Sul 23; Pernambuco 20; Mato Grosso 11, e, Paraíba 9.42.

Fundada no final dos anos 90, a União da Indústria de Cana-de-Açúcar (UNICA) é uma das principais organizações do setor sucroenergético, e, conta na atualidade com mais de 130 empresas associadas, que detêm mais de $60 \%$ do açúcar e $50 \%$ do etanol produzidos no país. Outra organização do setor é a União dos Produtores de Bioenergia (UDOP) fundada na década de 80. Até a safra 2008/09 a UNICA publicava em seu site o ranking das usinas no setor safra a safra. $\mathrm{O}$ quadro 08 a seguir contém os dados para aquela safra. Também o Ministério da Agricultura (MAPA) publicava estes dados por unidades de produção - usinas e destilarias. Porém, a partir da gestão de Marcos Savaia Jank, na presidência da UNICA, os dados não foram mais divulgados. E, o que foi pior, também, o MAPA deixou de divulgá-los, ou seja, o Estado passa a ser administrado pela lógica das empresas, e não, pelo princípio republicano de que a sociedade está acima de qualquer individuo ou empresa. Pura hipocrisia, pois, a maioria das empresas ou são S/A ou

\footnotetext{
28 "A Cosan, maior grupo sucroenergético brasileiro, anunciou nesta quarta-feira (5/6) que registrou uma receita líquida de R\$ 30 bilhões no ano fiscal 2013, contado entre 1 de abril de 2012 e 31 de março deste ano. O resultado representa um crescimento de $\mathbf{2 8 , 3 \%}$ em relação ao verificado no mesmo período do ano anterior, quando a receita totalizou $\mathrm{R} \$ 23$ bilhões. O menor crescimento econômico do País e a crise internacional reforçaram o foco da companhia na eficiência de suas operações, com evolução em vários aspectos do portfólio de negócios, seguindo a estratégia de crescimento nos segmentos de energia e infraestrutura."Disponível em < http://revistagloborural.globo.com/Revista/Common/0,ERT338956-18531,00.html>. Acesso em Out 2014.
} 
caminham para tal, e a legislação vigente, exige a publicação de seus balanços. E, eles estão em seus próprios sites na Internet e, lá estão os dados. Apenas o trabalho dos pesquisadores aumentou. O quadro 09 também a seguir, tem os dados quase completo da safra 2012/13. Os dados referentes à safra 2008/09, mostravam a Usina São Martinho de Pradópolis/SP, com a maior quantidade de cana moída, pouco mais de 8 milhões de toneladas. A empresa pertence ao grupo São Martinho cujo presidente do conselho em 2013 era João Guilherme Sabino Ometto. Em segundo lugar, ficou a Usina da Barra, em oitavo lugar a Usina Bonfim e em décimo quarto a Usina Costa Pinto, todas integrantes atualmente da Raízen/Cosan liderados por Rubens Ometto Silveira de Melo. E, em vigésimo lugar estava Usina São João de Araras/SP de outra parte da família Ometto liderados atualmente por Hermínio Ometto Neto. Assim, os descendentes da família Ometto na safra 2008/09, já controlavam 5 unidades entre as 20 principais existentes no país, que juntas moeram 28,1\% cana-de-açúcar para a produção de açúcar e etanol. (OLIVEIRA, 2014, Obra Inédita)

O mapa a seguir traz a distribuição territorial das unidades dos herdeiros da

família Ometto: Cosan/Raízen, São Martinho (que integrou a Santa Cruz à empresa), União São João e Santa Lúcia. (Mapa 11) 


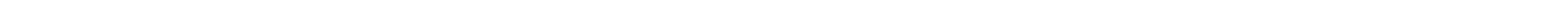


A seguir será apresenta sob a forma de uma tabela a trajetória histórica de constituição da Cosan S/A, iniciada com a fundação da Usina Costa Pinto em Piracicaba

no ano de 1936.

Quadro 01: Trajetória da Cosan

\begin{tabular}{|c|c|}
\hline 1936 & - Início das operações com a fundação da Usina Costa Pinto, em Piracicaba (SP). \\
\hline 1986 & $\begin{array}{l}\text { - Inicio do processo de expansão com aquisição de usinas no Estado de São Paulo. } \\
\text { Início da exportação de açúcar a partir da região centro-oeste do País. }\end{array}$ \\
\hline 1993 & $\begin{array}{l}\text { - Início das exportações de açúcar à granel e o lançamento do açúcar VHP (Very High } \\
\text { Pollarization), destinado ao mercado externo. }\end{array}$ \\
\hline 2000 & - Cosan S/A é oficialmente criada. \\
\hline 2001 & $\begin{array}{l}\text { - Inauguração da Fundação Cosan em Piracicaba, voltada à capacitação profissional e formação } \\
\text { cidadã para jovens da comunidade e filhos de funcionários. }\end{array}$ \\
\hline 2002 & $\begin{array}{l}\text { - Aquisição da Usina da Barra e início da implantação de uma tecnologia de geoprocessamento } \\
\text { com a utilização de imagens de satélite para monitorar as áreas agrícolas. }\end{array}$ \\
\hline 2004 & - Acesso ao mercado de capitais e internacionalização com o lançamento do bônus inaugural. \\
\hline 2005 & - Oferta pública inicial (IPO) da Cosan S.A na Bovespa, listada no segmento Novo Mercado. \\
\hline 2007 & - Oferta Pública Inicial (IPO) da Cosan Limited na Bolsa de Nova York - NYSE. \\
\hline 2008 & $\begin{array}{l}\text { - Compra dos ativos da Exxon Mobil no Brasil e início das atividades de distribuição de } \\
\text { combustíveis e lubrificantes; } \\
\text { - Lançamento da Radar, empresa voltada à compra e arrendamento de terras com alto potencial } \\
\text { agricultável }{ }^{29} \text {; } \\
\text { - Criação da Rumo, a maior operadora logística do mundo para açúcar destinado à exportação. }\end{array}$ \\
\hline 2009 & $\begin{array}{l}\text { - Aquisição do Grupo Novamérica com todos os produtos da marca União. } \\
\text { - Rumo assina contrato com América Latina Logística - ALL para transporte de açúcar a } \\
\text { granel. }\end{array}$ \\
\hline 2010 & $\begin{array}{l}\text { - Assinatura do acordo de associação com a Shell nos negócios de açúcar, etanol e distribuição } \\
\text { de combustíveis; } \\
\text { - Assinatura do Termo de Compromisso de Associação para criação de um sistema logístico } \\
\text { multimodal para transporte e armazenagem de etanol - LOGUM. }\end{array}$ \\
\hline
\end{tabular}

29 A Radar, unidade que investe em propriedades agrícolas e no arrendamento de terras no mercado imobiliário rural, encerrou o ano fiscal de 2013 com portfólio de terras próprias avaliado em R $\$ 2,5$ bilhões e área total de 107,5 mil hectares, distribuída entre seis Estados brasileiros: São Paulo, Maranhão, Mato Grosso, Bahia, Goiás e Mato Grosso do Sul. A receita líquida da Radar é composta pela venda de ativos e arrendamento de terras agrícolas. No quarto trimestre de 2013, não houve venda de propriedades e a receita líquida totalizou $\mathrm{R} \$ 15,4$ milhões, provenientes do arrendamento de terras. A redução de 23,5\% em relação ao mesmo período de 2012 está associada à oscilação de preços de commodities agrícolas, bem como a outras variáveis que influenciam no preço do arrendamento de terras. No ano fiscal de 2013, a receita líquida da Radar cresceu 27,6\% em relação a 2012, totalizando $\mathrm{R} \$ 86,9$ milhões, basicamente devido à venda de propriedades. Disponível em: < http://revistagloborural.globo.com/Revista/Common/0,,ERT338956-18531,00.html> . Acesso em Out. 2014. 


\begin{tabular}{|c|c|}
\hline 2011 & $\begin{array}{l}\text { - Criação da Raízen }{ }^{30}, \text { joint venture entre a Cosan e a Shell e uma das cinco maiores empresas } \\
\text { do Brasil. } \\
\text { - É criada a Cosan Biomassa } \\
\text { - Lançamento da Novvi, joint venture da Cosan e da Amyris voltada para o desenvolvimento } \\
\text { óleos básicos renováveis para o mercado de lubrificantes } \\
\text { - Início do processo de internacionalização da Cosan Lubrificantes, tornando-se distribuidor } \\
\text { exclusivo da marca Mobil na Bolívia, Uruguai e Paraguai. }\end{array}$ \\
\hline 2012 & $\begin{array}{l}\text { - Alienação da Cosan Alimentos. } \\
\text { - Aquisição da Comma Oil no Reino Unido, como mais um passo na internacionalização da } \\
\text { Cosan Lubrificantes. } \\
\text { - Rumo inaugura o Terminal Logístico de Itirapina, o maior e mais moderno do país. } \\
\text { - Acordo definitivo de aquisição de } 60,1 \% \text { do capital social da Comgás, a maior distribuidora } \\
\text { de gás canalizado do Brasil. }\end{array}$ \\
\hline 2013 & $\begin{array}{l}\text { - Emissão de Bond para aquisição da Comgás } \\
\text { - Raízen Combustíveis adquiri } 10 \% \text { das ações representativas do capital social da Serviços e } \\
\text { Tecnologia de Pagamentos S.A. (STP) - Sem Parar. }\end{array}$ \\
\hline 2014 & $\begin{array}{l}\text { - Em Maio foi aprovada a Incorporação das Ações da ALL pela Rumo, condicionada à } \\
\text { aprovação do CADE e da ANTT, bem como de eventuais outros órgãos que se façam } \\
\text { necessárias. } \\
\text { - É formada Joint Venture entre Raízen Combustíveis e Sapore, criada para atuar no segmento } \\
\text { de restaurantes e lojas de conveniência exclusivos em postos de rodovias da rede Shell. }\end{array}$ \\
\hline
\end{tabular}

Fonte: Disponível em: <www.cosan.com.br>. Acesso em Jan 2014. (Org. Natália Freire Bellentani)

\section{O monopólio do grupo Raízen Energia S/A revelado por meio da estratégia das}

fusões e aquisições pode ser verificado na seguinte relação:

[...] São as seguintes unidades agroindustriais que foram agrupadas no Estado de São Paulo: Costa Pinto- 1936 (Piracicaba), Santa Helena - 1986 (Rio das Pedras), São Francisco - 1986 (Elias Fausto), Ipaussu - 1988 (Ipauçu), Rafard

30 A COSAN S.A. INDÚSTRIA E COMÉRCIO (BM\&FBOVESPA: CSAN3; "Cosan") e COSAN LIMITED (BM\&FBOVESPA: CZLT11 e NYSE: CZZ), em continuidade aos Fatos Relevantes publicados em $1^{\circ}$ de fevereiro, 25 de agosto de 2010 e 7 de abril de 2011, anunciam que, em 1 de junho de 2011, concluíram com sucesso a reorganização societária conforme estabelecido no Framework Agreement assinado com a Shell Brazil Holdings B.V. ("Shell"). A formação da Raízen Energia Participações S.A. e da Raízen Combustíveis S.A. resulta na maior produtora mundial de açúcar, etanol e bioenergia a partir da cana-de-açúcar e numa das maiores distribuidoras de combustíveis do mercado brasileiro. A dívida líquida contribuída pela Cosan para a Raízen será de R \$ 4,94 bilhões, acrescidos de outros ajustes. Rubens Ometto Silveira Mello será o Presidente do Conselho de Administração das duas empresas pelo período de duração da Joint Venture. Ele terá um papel preponderante no seu desenvolvimento estratégico e crescimento, e receberá líquido um salário anual de aproximadamente $\mathrm{R} \$$ 13 milhões ("Remuneração Fixa"). Ele também terá direito a um bônus variável pelos próximos 5 anos, atrelado ao cumprimento de determinados indicadores de performance operacionais, que estão em linha com os indicadores estabelecidos para a Diretoria da Joint Venture. A sua meta de bônus anual será de $25 \%$ de sua Remuneração Fixa. A Joint Venture está sendo analisada pelo Conselho Administrativo de Defesa Econômica - CADE, o que não suspende a integração das companhias. (São Paulo, 2 de junho de 2011, Marcelo Martins, Diretor de Relações com Investidores)

${ }^{31} \mathrm{O}$ futuro da ALL foi decidido numa típica assembleia de acionistas, que durou apenas sete minutos e aprovou a incorporação pela Rumo. Assim, ainda que sem a maioria absoluta das ações, a maior ferrovia do país está nas mãos do empresário Rubens Ometto, dono do grupo Cosan, que terá maioria no conselho de administração da empresa. A ALL retoma agora sua capacidade de investimento. Embora a fusão ainda dependa da autorização do Cade, já há um plano de expansão sendo desenhado, com previsão de investimento de R $\$ 5$ bilhões até aproximadamente 2023. Esse valor pode alcançar R $\$ 8$ bilhões a depender de uma eventual extensão no prazo de concessão da ferrovia. 
- 2000 (Rafard), Diamante 2001 (Jaú), Gasa - 2001 (Andradina), Univalem 2001 (Valparaiso), Serra - 2001 (Ibaté), Barra - 2002 (Barra Bonita), Dois Córregos - 2002 (Dois Córregos), Junqueira - 2002 (Igarapava), Destivale 2005 (Araçatuba), Mundial - 2005 (Mirandópolis), Bom Retiro - 2006 (Capivari), Bonfim - 2006 (Guariba), Tamoio - 2006 (Araraquara), Benálcool - 2008 (Bento de Abreu), Tarumã - 2009 (Tarumã), Maracaí - 2009 (Maracaí), Paraguaçu Paulista - 2009 (Paraguaçu Paulista), Sertãozinho 2009 (Sertãozinho), e Zanin - 2010 (Araraquara). No estado de Goiás está a usina Jataí - 2010 (Jataí); e, no Mato Grosso do Sul a usina Caarapó - 2010 (Caarapó). Duas unidades agroindustriais são as mais importantes: Costa Pinto e Barra. As duas unidades fora do Estado de São Paulo são projetos novos greenfield. Várias unidades foram reagrupadas, ou desativadas e outras mudaram de nome com as aquisições e fusões que a Cosan empreendeu. Portanto, a constituição da Cosan foi feita no interior de um processo de verdadeira "nova acumulação primitiva do capital", via aquisição de empresas endividadas, acesso fácil ao crédito e políticas públicas de acesso aos fundos públicos, decorrentes das políticas neoliberais que desregulamentaram o setor. Ou seja, combinaram-se simultaneamente, introdução de $25 \%$ de adição do etanol anidro na gasolina e lançamento dos carros bicombustíveis flex. (OLIVEIRA, 2014, Obra Inédita)

A concentração, leia-se o crescimento de áreas do Estado de São Paulo destinadas a monocultura da cana-de-açúcar, continua forte e as maiores unidades agroindustriais em capacidade de moagem, concentram-se também nessa porção do país.

O maior grupo monopolista do setor sucroenenergético é o Raízen/Cosan que atua constituindo fusões territoriais monopolísticas (monopolistic territorial fusions), ou seja, territorializando o monopólio através, de seis exemplos: usinas Costa Pinto, Tamandupá (desativada), Bom Retiro, Rafard, Santa Helena, São Francisco e Santa Cruz (desativada) na região de Piracicaba/SP; as usinas Bonfim, Serra, Tamoio e Zanin na região de Araraquara/SP; as usinas Da Barra, Dois Córregos e Diamante na região de Jaú/SP; as usinas Gasa, Mundial, Univalem e Benálcool na região de Araçatuba/SP; as usinas Paraguassu, Maracaí, Tarumã na região de Assis/SP; e as usinas Jataí e Centro-Oeste/Montividiu na região de Jataí no estado de Goiás. Rubens Ometto Silveira de Mello é presidente do conselho de administração e o controlador da Cosan, a maior empresa do setor sucroenergético do país e do mundo. (OLIVEIRA, 2014, Obra Inédita) 
Tabela 14: Unidades agroindustriais do grupo monopolista territorializados Raízen Energia S/A (2013)

\begin{tabular}{|c|c|c|}
\hline $\begin{array}{l}\text { UNIDADES } \\
\text { AGROINDUSTRIAIS } \\
\text { RAÍZEN ENERGIA S/A }\end{array}$ & MUNICÍPIO & EDR/MUNICÍPIOS \\
\hline $\begin{array}{l}\text { ARARAQUARA } \\
\text { SERRA } \\
\text { TAMOIO }\end{array}$ & $\begin{array}{l}\text { Araraquara, Ibaté, } \\
\text { Araraquara }\end{array}$ & $\begin{array}{l}\text { ARARAQUARA } \\
\text { Américo Brasiliense - Araraquara - Boa } \\
\text { Esperança do Sul - Descalvado - Dourado - } \\
\text { Gavião Peixoto - Ibaté - Matão - Motuca - } \\
\text { Nova Europa - Ribeirão Bonito - Rincão - } \\
\text { Santa Lúcia - São Carlos - Tabatinga - Trabiju } \\
\text { - }\end{array}$ \\
\hline $\begin{array}{l}\text { BARRA } \\
\text { DIAMANTE } \\
\text { DOIS CRREGOS }\end{array}$ & $\begin{array}{l}\text { Barra Bonita, Jaú. Dois } \\
\text { Córregos }\end{array}$ & $\begin{array}{l}\text { JAÚ } \\
\text { Bariri - Barra Bonita - Bocaina - Boracéia - } \\
\text { Brotas - Dois Córregos - Igaraçu do Tietê - } \\
\text { Itaju - Itapuí - Jaú - Lençóis Paulista - } \\
\text { Macatuba - Mineiros do Tietê - Torrinha - }\end{array}$ \\
\hline $\begin{array}{l}\text { BENÁLCOOL } \\
\text { GASA } \\
\text { MUNDIAL } \\
\text { UNIVALEM }\end{array}$ & $\begin{array}{l}\text { Bento de Abreu, } \\
\text { Andradina, } \\
\text { Mirandópolis } \\
\text { Valparaíso }\end{array}$ & $\begin{array}{l}\text { ANDRADINA } \\
\text { Andradina - Bento de Abreu - Castilho - } \\
\text { Guaraçaí - Ilha Solteira - Itapura - Lavínia - } \\
\text { Mirandópolis - Murutinga do Sul - Nova } \\
\text { Independência - Pereira Barreto - Suzanápolis - } \\
\text { Valparaíso - }\end{array}$ \\
\hline $\begin{array}{l}\text { BOM RETIRO } \\
\text { COSTA PINTO } \\
\text { RAFARD } \\
\text { SANTA HELENA }\end{array}$ & $\begin{array}{l}\text { Capivari, Piracicaba, } \\
\text { Rafard, R. Das Pedras }\end{array}$ & $\begin{array}{l}\text { PIRACICABA } \\
\text { Águas de São Pedro - Americana - Capivari - } \\
\text { Cerquilho - Charqueada - Jumirim - Mombuca } \\
\text { - Nova Odessa - Piracicaba - Rafard - Rio das } \\
\text { Pedras - Saltinho - Santa Bárbara d'Oeste - } \\
\text { Santa Maria da Serra - São Pedro - Tietê - }\end{array}$ \\
\hline $\begin{array}{l}\text { MARACAÍ } \\
\text { PARAGUAÇU } \\
\text { TARUMÃ }\end{array}$ & $\begin{array}{l}\text { Maracaí, P. Paulista } \\
\text { Tarumã }\end{array}$ & $\begin{array}{l}\text { ASSIS } \\
\text { Assis - Borá - Campos Novos Paulista - } \\
\text { Cândido Mota - Cruzália - Echaporã - Florínia } \\
\text { - Ibirarema - Lutécia - Maracaí - Palmital - } \\
\text { Paraguaçu Paulista - Pedrinhas Paulista - } \\
\text { Platina - Quatá - Tarumã - }\end{array}$ \\
\hline S. FRANCISCO & Elias Fausto & $\begin{array}{l}\text { CAMPINAS } \\
\text { Campinas - Campo Limpo Paulista - Elias } \\
\text { Fausto - Hortolândia - Indaiatuba - Itatiba - } \\
\text { Itupeva - Jarinu - Jundiaí - Louveira - Monte } \\
\text { Mor - Morungaba - Paulínia - Sumaré - } \\
\text { Valinhos - Várzea Paulista - Vinhedo - }\end{array}$ \\
\hline DESTIVALE & Araçatuba & $\begin{array}{l}\text { ARAÇATUBA } \\
\text { Alto Alegre - Araçatuba - Avanhandava - } \\
\text { Barbosa - Bilac - Birigui - Braúna - Brejo } \\
\text { Alegre - Clementina - Coroados - Gabriel } \\
\text { Monteiro - Glicério - Guararapes - Luiziânia - } \\
\text { Penápolis - Piacatu - Rubiácea - Santópolis do } \\
\text { Aguapeí - }\end{array}$ \\
\hline
\end{tabular}

Fonte: ANUÁRIO DA CANA, safra 2012/2013. Ribeirão Preto: PROCANA, 2013.

(Org. Natália Freire Bellentani) 
Esta concentração realiza-se pela formação dos grupos e faz com que ocorra simultaneamente o processo conhecido como fusões territoriais monopolísticas, como pode ser vista pelo texto a seguir e pela figura constante no site da empresa:

[...] as fusões territoriais monopolísticas (monopolistic territorial fusions) constituem-se na expressão objetiva da territorialização dos monopólios no setor sucroenergético. Neles ocorrem as soldagens das alianças de classes e frações de classes entre os capitalistas industriais, que podem ser também, capitalistas agrícolas e proprietários de terra, e os demais proprietários de terra que podem ser também, capitalistas agrícolas fornecedores de matéria prima das unidades agroindustriais, ou mesmo simples proprietários de terra rentistas que as cedem sob contratos de arrendamentos, ativando ou desativando unidades agroindustriais, visando simultaneamente 0 uso. (OLIVEIRA, 2014, Obra Inédita)

\section{Figura 01: Clusters - Raízen Energia S/A}

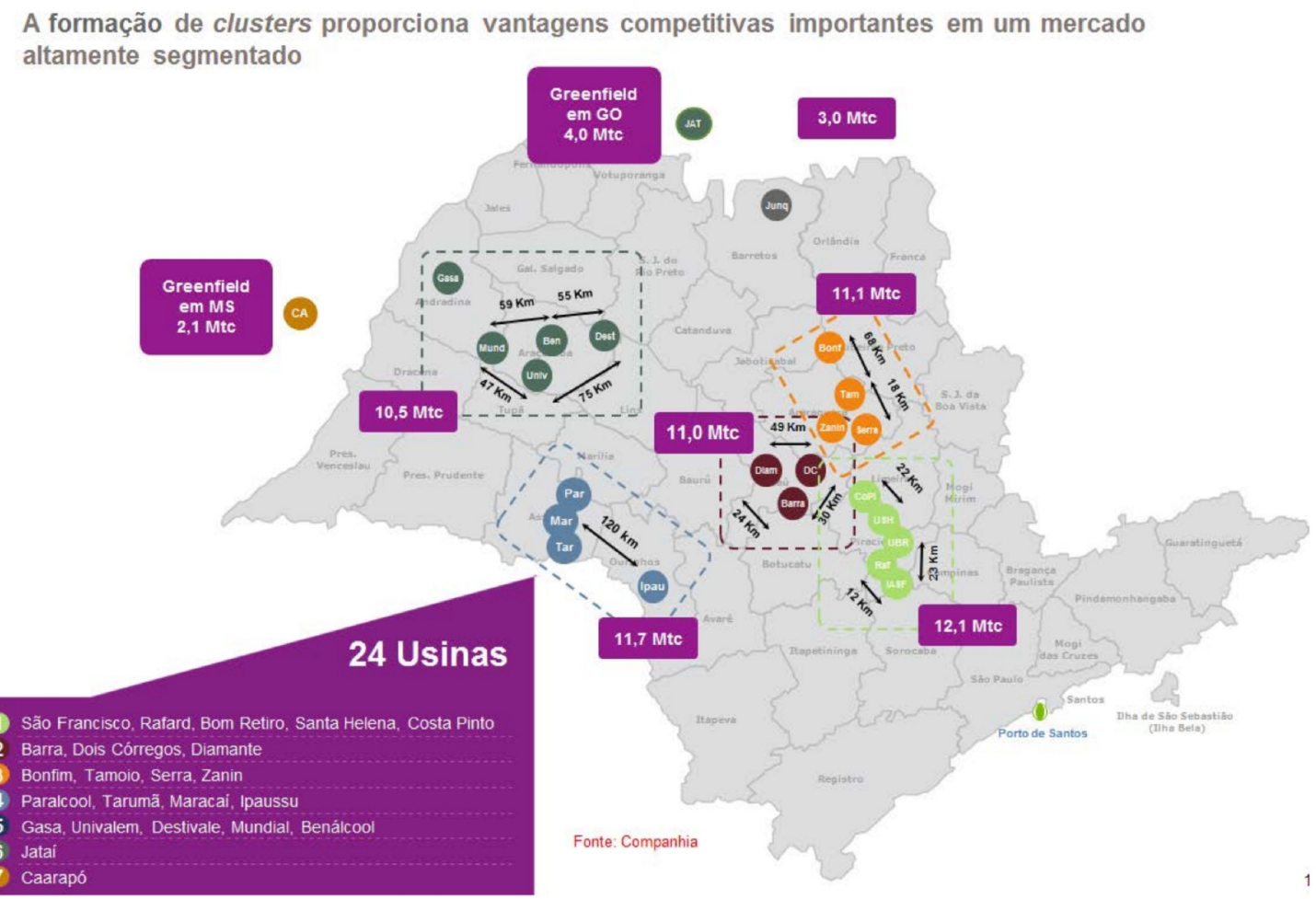

Fonte: Raízen Energia S/A Prospecto Preliminar de 4 de setembro de 2014.

[...] A concentração da produção no setor sucroenergético tem sido rápida, e, cinco anos depois, na safra de 2012/13, oito unidades de quatro grupos oriundos da família Ometto - São Martinho e Cosan/Raízen - moeram 38,380 milhões de toneladas de cana-de-açúcar, ou seja, $42,3 \%$ do total das 20 maiores unidades em operação. Cabe ainda acrescentar que a soma total das usinas da família Ometto (Cosan/Raízen, São Martinho, USJ e Santa Lúcia) perfizeram 81,237 milhões de toneladas de cana-de-açúcar moída, ou seja, $13,8 \%$ da safra nacional de 2012/13. (OLIVEIRA, 2014, Obra Inédita) 
Ao mesmo tempo, vale ressaltar que no caso da Raízen Energia S/A, todas as suas unidades agroindustriais, que disponibilizaram as informações da safra 2012/2013 para composição do Anuário da Cana 2013, apresentam um déficit na relação da capacidade de moagem da unidade e o quanto se mói de cana-de-açúcar por dia.

Esse dado é revelador da demanda que as unidades agroindustriais e consequentemente o grupo monopolista apresentam por mais área para plantio da canade-açúcar. Nessa dinâmica a Raízen Energia S/A tem consolidado a formação de seu monopólio no setor sucroenergético. (Tabela 15). 
Tabela 15: Grupo Raízen S/A e a produção na safra 2012/2013

\begin{tabular}{|c|c|c|c|c|c|c|}
\hline Raízen & Município & $\begin{array}{l}\text { Período Safra } \\
\text { (Total em dias) }\end{array}$ & $\begin{array}{c}\text { Moagem total } \\
\text { Período Safra (t) }\end{array}$ & $\begin{array}{l}\text { Moagem Diária } \\
\text { (Média safra) }\end{array}$ & $\begin{array}{c}\text { Capacidade } \\
\text { Moagem Diária (t) }\end{array}$ & $\begin{array}{l}\text { Defasagem } \\
\text { (t) }\end{array}$ \\
\hline Araraquara & Araraquara & - & $1.820 .307,00$ & - & 12.353 .00 & - \\
\hline Barra & Barra Bonita & 233 & $7.015 .543,00$ & 30109,63 & 40568,00 & 10458,37 \\
\hline Benálcool & B. de Abreu & 218 & $1.187 .593,00$ & 5447,67 & 7000,00 & 1552,33 \\
\hline Bom Retiro & Capivari & 246 & $1.140 .968,00$ & $4.638,08$ & 7000,00 & 2361,92 \\
\hline Bonfim & Guariba & 231 & $4.849 .863,00$ & 20995,08 & 29120,00 & 8124,92 \\
\hline Costa Pinto & Piracicaba & 220 & $3.607 .554,00$ & 16397,97 & 24905,00 & 8507,03 \\
\hline Destivale & Araçatuba & 221 & $1.283 .395,00$ & 5807,22 & 7700,00 & 1892,78 \\
\hline Diamante & $\mathrm{Jau}$ & 235 & $1.805 .427,00$ & 7682,67 & 11000,00 & 3317,33 \\
\hline Dois Córregos & Dois Córregos & 223 & $1.316 .375,00$ & 5903,03 & 7723,00 & 1819,97 \\
\hline Gasa & Andradina & 217 & $3.275 .383,00$ & 15093,93 & 20952,00 & 5858,07 \\
\hline Ipaussu & Ipaussu & 223 & $2.307 .279,00$ & 10346,54 & 15500,00 & 5153,46 \\
\hline Junqueira & Igarapava & 213 & $1.820 .307,00$ & 8546,04 & 12353,00 & 3806,96 \\
\hline Maracaí & Maracaí & 231 & $3.963 .958,00$ & 17159,99 & 17500,0 & 340,01 \\
\hline Mundial & Mirandópolis & 201 & $1.212 .750,00$ & 6033,58 & 8000,0 & 1966,42 \\
\hline Paraguaçu & P. Paulista & 235 & $1.085 .393,00$ & 4618,69 & 6000,0 & 1381,31 \\
\hline Rafard & Rafard & 210 & $2.146 .644,00$ & 10222,11 & 40568,0 & 30345,89 \\
\hline Santa Helena & R. das Pedras & 219 & $1.634 .091,00$ & 7461,60 & 11000,0 & 3538,40 \\
\hline S. Francisco & Elias Fausto & 210 & $1.324 .743,00$ & 6308,30 & 8400,0 & 2091,70 \\
\hline Serra & Ibaté & 219 & $1.649 .473,00$ & 7531,84 & 10000,0 & 2468,16 \\
\hline Tamoio & Araraquara & 209 & $1.201 .011,00$ & 5746,46 & 7300,0 & 1553,54 \\
\hline Tarumã & Tarumã & 240 & $3.663 .063,00$ & 15262,76 & 23515,0 & 8252,24 \\
\hline Univalem & Valparaiso & 211 & $1.921 .315,00$ & 9105,76 & - & - \\
\hline
\end{tabular}

Fonte: ANUÁRIO DA CANA, safra 2012/2013. Ribeirão Preto: PROCANA, 2013. (Org. Natália Freire Bellentani) 


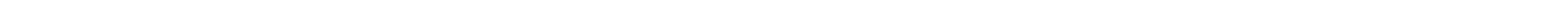


Depois de analisar a Raízen Energia S/A caminha-se para o estudo de outros grupos econômicos agroindustriais monocultores territorializados.

\section{BIOSEV S/A}

A empresa mundial Biosev S/A é o segundo maior monopólio territorializado no setor sucroenergético, ficando atrás apenas da Raízen Energia S/A. Oliveira (2014) afirmou que este grupo apresenta-se com o controle majoritário e gestão do capital estrangeiro:

[...] a Biosev S/A é um conglomerado de origem francesa cujos acionistas principais são: conglomerado Louis Dreyfus Commodities Company 58,4\% (Sugar Holdings B.v. 49,78\%, N1 Participations Holdings 2 B.v. 4,31\%, N1 Participations Holdings 4 B.v. 4,31\%), Fundo de Investimento em Participações Brazil Growth And Development 7,23\%, Ontário Teachers' Pension Plan Board 5,44\%, Santa Elisa Participações S/A 5,85\% e outros 1,73\%. (OLIVEIRA, 2014, Obra Inédita)

Paralelamente, Oliveira (2014) destacou que a empresa faz parte do conglomerado Louis Dreyfus Commodities que tem atuação mundial:

[...] Faz parte do Grupo Louis Dreyfus Commodities, com mais de 160 anos de experiência no mercado global de commodities e que se destaca pela posição de liderança nos mercados de açúcar, arroz, algodão, suco de laranja, soja e derivados, milho e trigo, entre outros. Presente em mais de 90 países sobre os cinco continentes, o Grupo Louis Dreyfus Commodities é um dos maiores comercializadores de açúcar do mundo e possui experiência internacional na produção e comercialização de etanol, sendo que em 30 de junho de 2012 representava cerca de $17 \%$ do total dos ativos do Grupo Louis Dreyfus Commodities. (Disponível em http://www.biosev.com/. Acesso em Maio 2014)

A trajetória histórica do grupo inclui estratégias para sua manutenção e expansão no setor sucroenergético, tais como aquisições, vendas e associações. O Quadro 02 traz a trajetória histórica da Biosev S/A entre os anos de 2000 e 2014. 
Quadro 02: Trajetória da Biosev S/A

\begin{tabular}{|c|c|}
\hline 2000 & $\begin{array}{l}\text { Início do processo de expansão via aquisições. Neste ano, a Louis Dreyfus Commodities, } \\
\text { adquiriu a Usina Cresciumal, localizada na cidade de Leme, em São Paulo. }\end{array}$ \\
\hline 2001 & $\begin{array}{l}\text { Aquisição da Usina Luciânia (atual Usina Lagoa da Prata), na cidade de Lagoa da Prata, Minas } \\
\text { Gerais, expandindo sua participação na região Centro-Sul do país. }\end{array}$ \\
\hline 2003 & Início das operações de cogeração na Usina Cresciumal. \\
\hline 2004 & Aquisição da Usina São Carlos, localizada em Jaboticabal. \\
\hline 2006 & $\begin{array}{l}\text { Início da expansão na Usina Lagoa da Prata e construção da unidade Rio Brilhante (projeto } \\
\text { greenfield) no estado de Mato Grosso do Sul. }\end{array}$ \\
\hline 2007 & $\begin{array}{l}\text { Aquisição das usinas da Tavares de Melo Açúcar e Álcool, expandindo as operações da } \\
\text { companhia para os estados do Rio Grande do Norte, Mato Grosso do Sul e Paraíba. A } \\
\text { capacidade de processamento alcançou } 11 \text { milhões de toneladas de cana-de-açúcar. }\end{array}$ \\
\hline 2008 & Início das operações da Usina Rio Brilhante. \\
\hline 2009 & $\begin{array}{l}\text { Associação entre a Biosev, até então chamada LDC Bioenergia, e a Santelisa Vale. A empresa } \\
\text { passa a ter } 13 \text { usinas e expande sua capacidade de processamento para } 40 \text { milhões de toneladas } \\
\text { de cana-de-açúcar. }\end{array}$ \\
\hline 2012 & A empresa aprova a alteração do seu nome para Biosev \\
\hline 2013 & $\begin{array}{l}\text { Com a venda de determinados ativos agrícolas da unidade São Carlos, a empresa passa a ter } 12 \\
\text { usinas com capacidade de processamento de } 37,9 \text { milhões de toneladas de cana-de-açúcar por } \\
\text { ano. A Biosev abre capital no Novo Mercado da BMF\&Bovespa. Tem início as operações da } \\
\text { cogeradora de energia da unidade Passa Tempo. }\end{array}$ \\
\hline 2014 & $\begin{array}{l}\text { Hibernação da unidade Jardest e capacidade de processamento de } 36,4 \text { milhões de toneladas de } \\
\text { cana-de-açúcar por ano. }\end{array}$ \\
\hline
\end{tabular}

Fonte: Disponível em < www.biosev.com>. Acesso em: Jan. 2014.

Organização: Natália Freire Bellentani

O grupo monopolista Biosev S/A vem territorializando o seu monopólio através de suas seis unidades agroindustriais localizadas em Colômbia, Leme, Jardinópolis, Morro Agudo e Sertãozinho e deste modo controla, ao mesmo tempo, o processo produtivo e agrícola ligado a produção da agroindústria canavieira nesta porção do território. O grupo possui duas fusões territoriais monopolísticas na região de Ribeirão Preto, chamada por ela de clusters: uma formada pelas usinas Jardest e Santa Elisa denominado São Paulo Sul, e, outro pelas usinas, MB, Vale do Rosário e Continental denominado São Paulo Norte. A Usina Cresciumal constitui-se em unidade isolada. OLIVEIRA, 2014, Obra Inédita) (Mapa 13) 


\section{TEREOS INTERNACIONAL S/A}

O grupo formado pela Tereos Internacional S/A, através do Açúcar Guarani S/A, tem participação de $61,4 \%$ que somado a uma parceria estratégica de 39,6\% da Petrobras Biocombustível - Pbio (este percentual pode chegar por contrato entre as empresas a 45,7\%) ${ }^{32}$ compõe seu capital. Na safra 2012/13, moeu 19,7 milhões de toneladas de cana ( $3^{\mathrm{a}}$ posição), produzindo: 1,6 milhão de toneladas de açúcar $\left(2^{\mathrm{a}}\right.$ posição), 584,930 mil metros cúbicos de etanol, ocupando a $3^{\text {a }}$ posição no ranking nacional.

A história da formação do grupo monopolista Tereos Internacional S/A, contada por ele mesmo, é apresentada no Quadro 03 que traz a trajetória histórica do grupo. Nesta trajetória é possível observar que a territorialização do monopólio da Tereos Internacional S/A se dá por meio da atuação de suas sete unidades agroindustriais que vem controlando uma porção do Estado de São Paulo, como também será possível verificar no Mapa 14 apresentado a seguir.

As unidades agroindustriais do grupo monopolista Tereos Internacional estão concentradas territorialmente nas regiões de Barretos/SP, Bebedouro/SP e norte de Rio Preto/SP, formando praticamente uma única grande fusão territorial monopolística. (OLIVEIRA, 2014)

\footnotetext{
32 (Disponível em: http://www.tereosinternacional.com.br/show.aspx?idCanal=u+Q7sscY4GtK5333Tgs9wQ==e http://siteempresas.bovespa.com.br/consbov/ArquivosExibe.asp?site=\&protocolo $=243620$. Acesso em Nov. 2014.)
} 
Quadro 03: Trajetória da Tereos Internacional S/A

\begin{tabular}{|c|c|}
\hline 1967 & $\begin{array}{l}\text { Começa a história da Guarani. Em uma época de crescimento econômico no País, a empresa } \\
\text { abre suas portas oferecendo álcool, aguardente e coprodutos na região de Severínia, interior de } \\
\text { São Paulo. }\end{array}$ \\
\hline 1976 & Unidade de Severínia da Guarani é adquirida pelo Grupo Gafisa. \\
\hline 1987 & $\begin{array}{l}\text { Uma mudança tecnológica marca a Guarani. A empresa constrói sua segunda unidade } \\
\text { industrial, a Cruz Alta, no município de Olímpia, próximo à Severínia, interior de São Paulo. } \\
\text { A fábrica, pioneira no Brasil, traz o que há de mais moderno no setor, utilizando um difusor de } \\
\text { cana-de-açúcar, no lugar da tradicional moenda. }\end{array}$ \\
\hline 1990 & $\begin{array}{l}\text { Inauguração da refinaria na Unidade Industrial Cruz Alta, para a produção de açúcar amorfo e } \\
\text { açúcar líquido para a indústria de alimentos e bebidas, e também açúcar refinado granulado } \\
\text { para exportação. }\end{array}$ \\
\hline 2000 & $\begin{array}{l}\text { O Grupo Tereos começa a investir no setor sucroenergético brasileiro por meio da criação da } \\
\text { FBA (Franco Brasileira S/A), uma joint venture. É a primeira empresa estrangeira a entrar no } \\
\text { setor no Brasil. }\end{array}$ \\
\hline 2001 & $\begin{array}{l}\text { O Grupo Tereos se estabelece fisicamente no Brasil assumindo o controle acionário da } \\
\text { Guarani. Inicia-se uma fase de amplo desenvolvimento da empresa, que se moderniza, cresce e } \\
\text { adquire outras empresas do setor. }\end{array}$ \\
\hline 2003 & A Guarani duplica sua capacidade de moagem na Unidade Cruz Alta, em Olímpia. \\
\hline 2004 & Inaugurada a destilaria de etanol na Unidade Cruz Alta, em Olímpia. \\
\hline 2005 & Modernização da Unidade Severínia. \\
\hline 2006 & Aquisição da Unidade São José, em Colina e do projeto da Unidade Tanabi. \\
\hline 2007 & $\begin{array}{l}\text { Incorporação da Unidade Andrade (Pitangueiras) e inauguração da Unidade Tanabi. Grupo } \\
\text { Tereos assume a gestão da Unidade Sena, em Moçambique. }\end{array}$ \\
\hline 2008 & $\begin{array}{l}\text { Guarani e a Tractebel, maior empresa privada de geração de energia do Brasil, participam do } \\
\text { primeiro Leilão de Energia de Reserva promovido pela Agência Nacional de Energia Elétrica - } \\
\text { ANEEL. }\end{array}$ \\
\hline 2009 & $\begin{array}{l}\text { Em agosto de 2009, dá início ao projeto de construção de uma usina de biomassa da Unidade } \\
\text { Andrade. }\end{array}$ \\
\hline 2010 & $\begin{array}{l}\text { Aquisição de } 50 \% \text { da Usina Vertente, em Guaraci, associando-se ao Grupo Humus nessa } \\
\text { usina. Criação e listagem da Tereos Internacional na BM\&FBovespa. Criou-se uma empresa } \\
\text { internacional que reúne os ativos de açúcares, amidos e outros produtos provenientes do } \\
\text { processamento de cana-de-açúcar, cereais, batata e mandioca do Grupo Tereos no mundo. } \\
\text { Tereos Internacional forma uma parceria com a Petrobras Biocombustível para investir no } \\
\text { crescimento da Guarani. O primeiro fruto dessa parceira foi a aquisição da atual Unidade } \\
\text { Mandu (Guaíra). }\end{array}$ \\
\hline 2011 & $\begin{array}{l}\text { Filia-se ao Bonsucro e inicia a produção de etanol anidro na Unidade Tanabi e inaugura a } \\
\text { destilaria na Unidade São José. }\end{array}$ \\
\hline 2012 & $\begin{array}{l}\text { Amplia sua capacidade de cogeração com novas caldeiras em suas unidades Cruz Alta e São } \\
\text { José. Adquire participação }(35 \%) \text { no Terminal Portuário Teapar. }\end{array}$ \\
\hline 2013 & $\begin{array}{l}\text { Usina Vertente conquista a certificação FSSC } 22000 \text { e Unidades Cruz Alta e Severínia } \\
\text { recebem a certificação Bonsucro. Amplia a capacidade de cogeração na Usina Vertente e } \\
\text { unidade Tanabi }\end{array}$ \\
\hline 2014 & $\begin{array}{l}\text { Busca competitividade e excelência de seus processos agroindustrial e comercial, lançando o } \\
\text { Programa Guarani } 2016 .\end{array}$ \\
\hline
\end{tabular}

Fonte: Disponível em <www.aguarani.com.br >. Acesso em: Jan. 2014.

Organização: Natália Freire Bellentani 
Figura 02: Estrutura societária da Tereos Internacional S/A

\section{Estrutura societária}

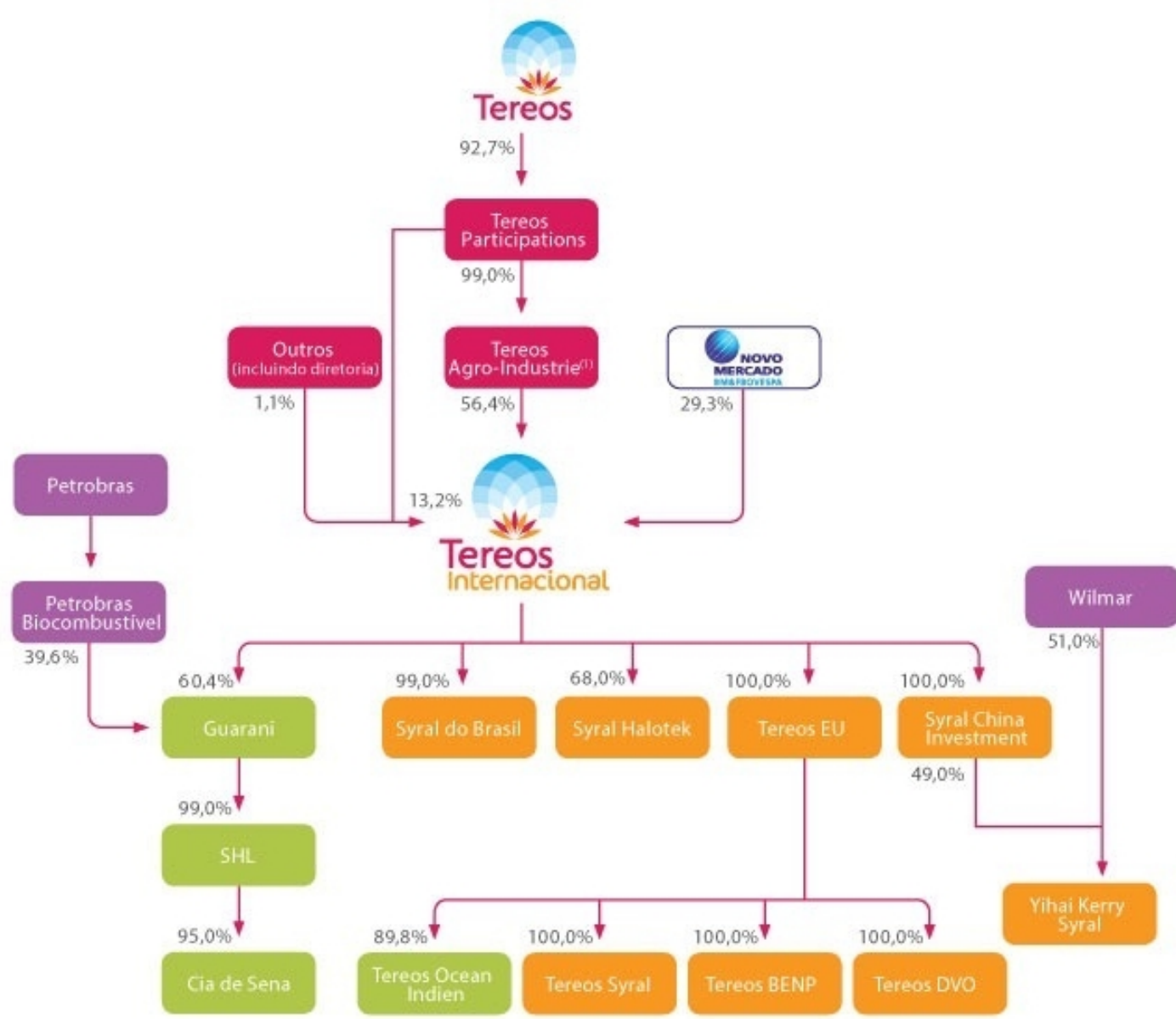

Fonte: Tereos Internacional S/A Disponível em:

http://www.tereosinternacional.com.br/show.aspx?idCanal=u+Q7sscY4GtK5333Tgs9wQ=. Acesso em Novembro de 2014. 


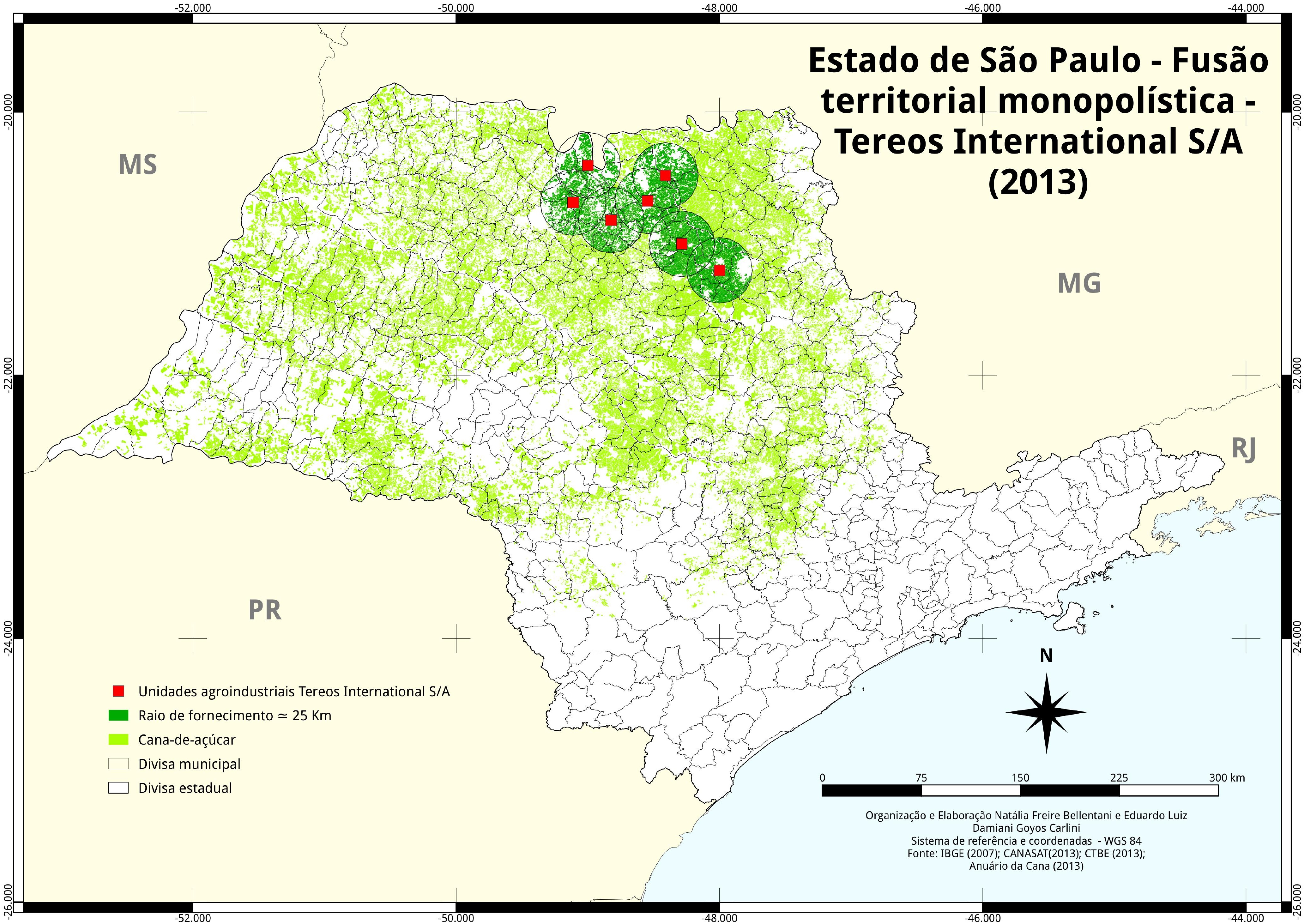




\section{ODEBRECHT AGROINDUSTRIAL S/A}

O grupo monopolista Odebrecht que atua no setor sucroenergético desde 2007 apresenta a seguinte configuração acionária: Odebrecht S/A 53\%, BNDESPar 14,4\%, Brenco (Brazilian Renewable Energy Company) 16,5\% (Ashmore 13,1\%, Tarpon 2,4\% e $1,0 \%$ outros), Sojitz Corporation $16,1 \%)$.

Na safra 2012/13, moeu o total de 18,917 milhões de toneladas de cana-deaçúcar, produzindo 384,565 mil toneladas de açúcar (17o lugar) e 1,345 milhão metros cúbicos de etanol, ocupando o $1^{\mathrm{o}}$ lugar no ranking nacional.

[...] A Odebrecht Agroindustrial foi fundada em 2007, pela Organização Odebrecht, sua controladora. Produz e comercializa etanol e açúcar VHP e cogera energia elétrica a partir da biomassa. Sua produção de etanol é vendida às distribuidoras de combustível, que o utilizam como etanol hidratado (o álcool combustível) e etanol anidro (o álcool acrescentado à gasolina), e para a indústria química e petroquímica para a produção de biopolímeros. Toda a produção de açúcar é exportada, e a energia que cogera lhe dá autossuficiência energética e o excedente é vendido para a o sistema elétrico brasileiro e para o mercado livre.Com sede na cidade de São Paulo, a empresa tem sua base de operação no Brasil e tem Unidades Agroindustriais em quatro estados brasileiros: São Paulo, Mato Grosso, Mato Grosso do Sul e Goiás. Nestes estados, opera por meio de polos produtivos para garantir maior sinergia entre as operações agrícolas e industriais. Dessa forma, divide suas atividades entre os Polos: São Paulo - com as Unidades Alcídia e Conquista do Pontal; Araguaia - com as Unidades Morro Vermelho e Água Emendada Taquari - com as Unidades Alto Taquari e Costa Rica; Santa Luzia - com a Unidade Santa Luzia; Eldorado - com a Unidade Eldorado; Goiás - com a Unidade Rio Claro. (Disponível em: http://www.odebrechtagroindustrial.com/sobre-eth/quem-somos\#sthash.ThG DOnLK.dpuf. Acesso em Jun 2014.)

O grupo nacional Odebrechet que realiza sua fusão territorial monopolística na porção oeste do Estado de São Paulo, materializa esse processo por meio de suas duas unidades agroindustriais: Alcídia e Conquista do Pontal, localizadas nos municípios de Teodoro Sampaio e Mirante do Paranapanema, respectivamente. (OLIVEIRA, 2014, Obra Inédita) 


\section{BUNGE LIMITED}

Este grupo sucroenergético monopolista territorializado no Estado de São Paulo, possui controle acionário estrangeiro. De acordo com Oliveira (2014:Inédito), a Bunge tem como sócio a Moema Participações S/A que ficou com 9\% do capital mundial da multinacional e atua em parceria com a Itochu Corporation em duas usinas de açúcar e etanol no Brasil (20\% das unidades de Santa Juliana, em Minas Gerais, e de Pedro Afonso, em Tocantins).

[...] A Bunge entrou no mercado mundial de açúcar como trader em 2006, e desde então construiu uma forte posição na comercialização e produção de açúcar e etanol.

Hoje, a empresa está entre as líderes no processamento de cana no Brasil e opera oito usinas com capacidade combinada de aproximadamente 21 milhões de toneladas por ano. (Disponível em: http://www.bunge.com.br/Negocios/Acucar_Bioenergia.aspx. Acesso em Mai 2013)

O grupo holandês Bunge territorializa o monopólio por meio de suas três unidades agroindustriais, constituindo fusões territoriais monopolísticas na porção noroeste do campo paulista (Alta Araraquarense). (OLIVEIRA, 2014, Obra Inédita)

\section{CLEALCO}

O grupo Clealco iniciou sua trajetória no setor sucroenergético ainda na década de 1980 e segue construindo uma sólida estrutura para seus negócios no campo, garantindo na safra 2012/13, 14.057.683 milhões de toneladas de cana moída, o que lhe conferiu o $5^{\circ}$ lugar no ranking da moagem dos grupos dos setor sucroenergético.

[...] No final da década de 70, o petróleo, matriz energética que o país importava, passava por uma crise. O preço do barril subia constantemente, gerando incertezas na economia nacional. Para acabar com a dependência do petróleo importado, o Governo Brasileiro lançou o projeto de plantio da canade-açúcar para a produção do etanol combustível, uma nova alternativa de matriz energética. Por causa da produção do etanol, o impacto da importação de petróleo na economia nacional diminuiu. A produção da nova matriz energética brasileira gerou mais empregos na zona rural do país. Atendendo ao apelo do Governo Brasileiro, políticos, pecuaristas e agricultores 
apostaram na nova atividade de geração de energia renovável na região de Clementina. Eles formaram uma associação para reunir terras para o plantio de dois mil alqueires e viabilizar a construção de uma usina. No dia 5 de dezembro de 1980, reuniram-se os acionistas em assembléia geral, constituindo formalmente a empresa. Em 11 de janeiro de 1981, foi aprovado o Projeto pelo CENAL (Conselho Nacional do Álcool). Logo depois, começaram as obras da destilaria. A moagem da primeira safra ocorreu em 1983. A criação da usina proporcionou empregos diretos e indiretos para Clementina e 26 municípios da região. (Disponível em: $<$ www.clealco.com.br>. Acesso em Junho 2014)

O grupo monopolista Clealco territorializa o monopólio através de três exemplos que são as suas unidades agroindustriais, localizadas nos municípios de Clementina; Queiroz; e Tupã. O grupo controla a propriedade privada capitalista da terra e também o processo produtivo e agrícola, constituindo uma fusão territorial monopolística. (OLIVEIRA, 2014, Obra Inédita)

\section{SÃO MARTINHO S/A}

O grupo monopolista São Martinho, na safra 2012/13, moeu o total de 13,016 milhões de toneladas de cana-de-açúcar, produzindo 875,007 mil toneladas de açúcar, o que lhe conferiu o $4^{\circ}$ lugar no ranking nacional. E, paralelamente, produziu 522,050 metros cúbicos de etanol, ocupando novamente o $4^{\circ}$ lugar do ranking nacional.

Em 2013, o presidente do conselho do grupo era João Guilherme Sabino Ometto que no mesmo momento assumiu, também, o cargo de vice-presidente da FIESP (Federação das Indústrias do Estado de São Paulo).

Salutar lembrar que a história do grupo São Martinho é parte integrante da história da família Ometto:

[...] A história do Grupo São Martinho teve início na Itália, no final do século XIX, quando integrantes da família Ometto imigraram para o Brasil. $\mathrm{Na}$ ocasião, eles trouxeram na bagagem o sonho e a esperança de conseguir melhores condições de vida e de trabalho no novo país. No interior de São Paulo, trabalharam unidos e perseverantes, pavimentando pouco a pouco 
uma trajetória de raro sucesso. No sítio Olaria montaram seu primeiro engenho de cana-de-açúcar, em 1914. Já em 1932, na Fazenda Boa Vista, região de Limeira, a família produziu açúcar pela primeira vez. Em 1937, a Usina Iracema foi comprada em Iracemápolis, município localizado no interior de São Paulo, e transformou-se em uma destilaria de álcool. Em 1946, a usina passou a fabricar açúcar também. Três anos mais tarde, os Ometto adquiriram a Usina São Martinho, situada na cidade de Pradópolis, distante cerca de 330 quilômetros de São Paulo, que se transformou em uma das maiores processadoras de cana do mundo. Ao longo das décadas, as duas usinas cresceram e se modernizaram. Desde 2000, criou-se uma estrutura unificada para administrar o negócio de maneira cada vez mais profissionalizada, possibilitando novas oportunidades de investimento. Canade-açúcar 1926: O Grupo São Martinho está entre os maiores conjuntos sucroenergéticos do Brasil, com três usinas em operação: São Martinho, localizada no município paulista de Pradópolis (região de Ribeirão Preto), Iracema, situada na cidade de Iracemápolis (região de Limeira, SP), e Boa Vista, em Quirinópolis, a 300 quilômetros de Goiânia, em Goiás, que integra a Nova Fronteira Bioenergia, empresa formada por meio da parceria entre o Grupo São Martinho e a Petrobras Biocombustível. Além das três usinas, o Grupo possui uma unidade para produção de ácido ribonucleico, a Omtek, também localizada em Iracemápolis, e é detentor de 36,08\% da Santa Cruz Açúcar e Álcool, localizada no município paulista de Américo Brasiliense ${ }^{33}$. $\mathrm{O}$ escritório corporativo encontra-se na capital paulista e o Centro de Serviços Compartilhados (CSC) está em Pradópolis. O local reúne as áreas administrativas, financeira, jurídica, de recursos humanos e de suprimentos, além de informática e controladoria. $\mathrm{O}$ conceito de grupo empresarial foi consolidado nos últimos anos com a padronização de uma marca. Isto ajudou a fortalecer o desempenho, principalmente com a abertura do capital da companhia em 2007, buscando assim uma competitividade cada vez maior nos mercados em que atua. (Disponível em: < http://www.mzweb.com.br/saomartinho2009/web/conteudo_pti.asp?idioma= $0 \&$ tipo $=28764 \&$ conta $=45$. Acesso em Ago 2014.)

\title{
Como apresentou Oliveira (2014) o último negócio feito pelo grupo foi a
}

\author{
aquisição do controle acionário da Usina Santa Cruz S/A - Açúcar e Álcool em maio de
}

2014, cujo objetivo principal foi o fortalecimento da fusão territorial monopolística das

\footnotetext{
33 O Conselho Administrativo de Defesa Econômica (Cade) aprovou operação pela qual a São Martinho adquire participação societária adicional na Santa Cruz S.A Açúcar e Álcool, passando dos atuais 36,09\% para 92,14\% do capital social da empresa. O negócio foi firmado com os vendedores Luiz Ometto Participações (LOP) e demais acionistas controladores pessoas físicas da Santa Cruz. O aval do Cade está publicado no Diário Oficial da União (DOU) sem nenhuma restrição aos termos de memorando de entendimentos assinado entre as partes em maio deste ano. Pelo documento, a compra - pela São Martinho - de participação de 56,05\% do capital social da Santa Cruz, incluindo terras, custará R\$ 315,8 milhões, e o pagamento será feito em dez anos, corrigido pelo CDI. O acordo também prevê que a São Martinho venderá a totalidade de suas ações da Agro Pecuária Boa Vista para a LOP. A venda dessas ações, num total de 34,29\%, para a LOP será pelo valor de R \$ 195,9 milhões, também em dez anos e corrigido pelo CDI. Segundo fato relevante divulgado em maio, ao todo a São Martinho desembolsará R\$ 119,9 milhões pelo negócio, que ainda inclui a celebração de contrato de arrendamento de cana-de-açúcar entre a Santa Cruz e a Agro Pecuária Boa Vista por um período de 20 anos. "Aprovada compra da Santa Cruz Açúcar pela São Martinho". Disponível em: <www.exame.abril.com.br/negocios/noticias/aprovadacompra-da-santa-cruz-acucar-pela-sao-martinho>. Acesso em: Julho 2014.
} 
Usina São Martinho em Pradópolis/SP e Santa Cruz em Américo Brasiliense/SP. Dessa

forma, a São Martinho S/A assumiu o controle da Santa Cruz S/A (92,14\%) e da

Bioenergética Santa Cruz (100\%), enquanto que uma de suas acionistas a Luis Ometto

Participações S/A assumiu o controle da Agropecuária Boa Vista S/A (92,12\%).

São Martinho S.A. assina memorando de entendimentos vinculante para a consolidação do controle da Santa Cruz S.A. Açúcar e Álcool e venda de participação acionária na empresa de terras Agro Pecuária Boa Vista S.A.

São Paulo, 05 de maio de 2014 - São Martinho S.A. (BM\&FBovespa: SMTO3; Reuters: SMTO3 SA e Bloomberg: SMTO3 BZ), um dos maiores produtores de açúcar e etanol do Brasil, em cumprimento ao disposto no artigo $3^{\circ}$ da Instrução CVM no $358 / 02$, comunica a seus acionistas e ao mercado em geral que, nesta data, assinou memorando de entendimentos com a Luiz Ometto Participações S.A. ("LOP") e demais acionistas controladores pessoas físicas ("PFs") da Santa Cruz S.A. Açúcar e Álcool ("SC" ou "Santa Cruz") para, concomitantemente: (I) adquirir de LOP e PFs participação societária adicional na Santa Cruz, passando dos atuais 36,09\% para 92,14\% do capital social da SC; (II) vender a totalidade de suas ações da Agro Pecuária Boa Vista S.A. ("APBV") para a LOP; e (III) celebrar contrato de arrendamento de cana-de-açúcar entre a Santa Cruz e a APBV, por um período de 20 anos ("Operação"). A SC possui capacidade de moagem de 4,5 milhões de toneladas de cana-de-açúcar, com flexibilidade de $60 \% / 40 \%$ na produção de açúcar e etanol. Referida companhia tem um dos maiores índices de integração no suprimento de cana-de-açúcar ( $80 \%$ de cana própria), regulados através de contratos de arrendamento e/ou parcerias agrícolas de longo prazo.

Adicionalmente à usina, 2.002 hectares de terras são de propriedade direta da SC e farão parte da transação ("Terras"). Estas Terras estão a um raio médio inferior a $9 \mathrm{~km}$ de distância da $\mathrm{SC}$ e possuem produtividade média de 95 toneladas/hectare por safra. Segundo laudo preparado pela Deloitte Touche em fevereiro de 2014, referidas Terras foram avaliadas, a valor de mercado, em $\mathrm{R} \$$ 68,3 milhões. Em 31 de março de 2014, o endividamento líquido da SC somava R\$ 658,6 milhões.

A Bioenergética Santa Cruz ("BSC") - empresa de cogeração de energia elétrica controlada integralmente pela $\mathrm{SC}$ - possui capacidade de cogeração de 220.000 MWh por safra, das quais 175.200 MWh, já se encontram contratadas até o ano de 2025 ao preço de R\$ 205/MWh, reajustado pelo IPCA anualmente.

$\mathrm{Na}$ safra 13/14, a BSC registrou lucro líquido de $\mathrm{R} \$ 38,6$ milhões. Em 31 de março de 2014, a BSC possuía caixa de R\$ 6,7 milhões, sem qualquer endividamento bancário.

A APBV - empresa controlada pelos acionistas da Santa Cruz - detém 20.144 hectares de terras, localizados a um raio médio de $27 \mathrm{~km}$ de distância da unidade industrial da SC. Historicamente, a produtividade das terras da APBV encontra-se acima de 80 toneladas por hectare, considerando ciclos de 6 a 7 anos. Segundo o laudo preparado pela Deloitte Touche em fevereiro de 2014, referidas terras foram avaliadas, a valor de mercado, em R\$ 602,0 milhões. Em 31 de março de 2014, a APBV possuía endividamento líquido de R\$ 30,8 milhões. (Disponível em: 
$<$ http://www.bmfbovespa.com.br/empresas/consbov/ArquivoComCabecalho. asp? motivo $=\&$ protocolo $=423929 \&$ funcao $=$ visualizar\&site $=B>$. Acesso em Agosto de 2014.)

O grupo monopolista além de sua fusão monopolística territorial envolvendo suas unidades agroindustriais localizadas nos municípios de Pradópolis e Américo Brasiliense e possui também uma unidade isolada em Iracemápolis, Usina Iracema. Trata-se de uma das primeiras usinas do grupo. (OLIVEIRA, 2014, Obra Inédita)

\section{NOBLE GROUP}

De acordo com Oliveira (2014: Inédito) o Noble Group Limited é um conglomerado que atua em vários setores, tais como, produtos agrícolas, energia, metais, minerais e minérios. Ocupa o $7^{\circ}$ lugar no ranking nacional de moagem da cana no setor sucroenergético, o que significa um total de 10, 687 milhões de toneladas, em 2013. É um grupo que:

[...] Tem sede em Hong Kong na China e está listado na Bolsa de Cingapura. Atua particularmente na China onde é um dos principais processadores de oleaginosas com cinco unidades agroindustriais, e, atua também nos demais países do Sudeste Asiático e no Oriente Médio (Arábia Saudita, Jordânia, Dubai e Egito). Na Europa, tem na Turquia suas principais operações de importação de grãos e oleaginosas; na Rússia ficam as unidades de armazenagem de grãos e oleaginosas para exportação; na Itália fica a base para comercialização de grãos na porção central do velho continente; em Genebra, na Suíça é o principal polo da empresa para atuação nos países do Mediterrâneo e do Mar Negro. Na América do Sul, o Noble Group tem rede de armazéns e silos operando com oleaginosas e grãos de terceiros no Brasil, Argentina, Uruguai e Paraguai. O grupo atua no Brasil, no setor de grãos, café e sucroenergético através de sua subsidiária Noble Brasil S/A. Especificamente no setor sucroenergético opera através da empresa do grupo NG Bioenergia S/A. Possui quatro unidades na região de São José do Rio Preto/SP: Sebastianópolis (2007), Meridiano (2009), Catanduva (2010), Potirendaba (2010) situadas em municípios do mesmo nome. As duas últimas unidades foram adquiridas da família Fernandes do grupo Cerradinho. Já as terras onde estão as plantações de cana que abastecem as duas usinas de São Paulo também continuaram como propriedade da família. Assim, consolidase sob tutela do capital estrangeiro, mais uma aliança de classe com a burguesia brasileira neste setor. (OLIVEIRA, 2014, Obra Inédita) 
O grupo chinês Noble atua constituindo duas fusões territoriais monopolísticas por meio de suas unidades agroindustriais Catanduva e Meridiano; e, Potirendaba e Sebastianópolis, localizadas nos municípios de Catanduva, Meridiano, Potirendaba e Sebastianópolis do Sul, respectivamente. (OLIVEIRA, 2014, Obra Inédita)

\section{ZILLOR LORENZETTI}

O grupo nacional Zillor, tem sua origem vinculada às empresas da família Zillor Lorenzetti e data sua fundação em 1946. Hoje se apresenta como cooperada da Copersucar e em 2013 produziu 526.100 toneladas de açúcar e 492,7 milhões de litros de etanol.

[...] A Zilor desenvolve soluções naturais a partir de processos biotecnológicos, por meio da Biorigin, sua unidade de negócios especializada na produção de ingredientes para alimentação humana e nutrição animal. A Zilor é uma das acionistas da Copersucar S.A., maior empresa brasileira de açúcar e etanol e uma das maiores exportadoras mundiais desses produtos. (Disponível em: <www.zilor.com.br>. Acesso em Maio 2014.)

O grupo monopolista Zillor vem territorializando o seu monopólio através de suas três unidades agroindustriais Barra Grande; Quatá; São José, localizadas Lençóis Paulista, Quatá e Macatuba onde vem controlando nesta porção do território, ao mesmo tempo, o processo produtivo e agrícola canavieiro. As unidades de Lençóis Paulistas e Quatá realizam o processo de fusão monopolista territorial. (OLIVEIRA, 2014, Obra Inédita)

\section{RENUKA DO BRASIL}

O grupo Renuka do Brasil é controlado pela indiana Shree Renuka Sugars. De acordo com o periódico "Valor Econômico", veiculado em 09 de outubro de 2012, o grupo foi criado em 2009 após a aquisição pela sua controladora, a Shree Renuka 
Sugars, da participação majoritária (atualmente em 59,4\%) da Equipav Açúcar e Álcool, que vinha de um elevado endividamento.

[...] A Renuka do Brasil iniciou suas atividades em Promissão, SP, no ano de 1981, ainda sob a razão social de Equipav S. A. Açúcar e Álcool. Em 2008, ainda sob controle do Grupo Equipav, foi inaugurada a Biopav S.A. Açúcar e Álcool, em Brejo Alegre, SP. Em 2010, a empresa indiana Shree Renuka Sugar adquiriu participação majoritária nas duas usinas, rebatizou a Biopav com o nome de Revati e a Usina Equipav com o nome Usina Madhu.

A Renuka do Brasil é um dos 10 maiores grupos sucroalcooleiros do Brasil, em atividade há mais de 30 anos. Em meados de 2010, a Shree Renuka Sugars adquiriu o controle acionário da companhia. A capacidade instalada de moagem de 10,5 milhões de toneladas divide-se entre a Usina Equipav, em Promissão, e a Usina Revati, em Brejo Alegre, ambas as cidades localizadas no Estado de São Paulo, a maior região produtora de cana-deaçúcar do mundo. Entre os seus principais produtos estão: açúcar, etanol, bioeletricidade e levedura. A Renuka do Brasil tem uma estrutura amplamente verticalizada, controlando não só todos os processos industriais, mas também todos os agrícolas, tais como o plantio, cultivo, colheita e transporte da cana. (Disponível em: < http://www.renukadobrasil.com.br/br/home> Acesso em Ago 2014.)

O grupo Renuka territorializa o monopólio através de suas duas unidades agroindustriais: Usina Mandhu em Promissão, e, Usina Revati em Brejo Alegre.

\section{PEDRA AGROINDUSTRIAL}

O grupo monopolista Pedra Agroindustrial na safra 2012/13, moeu 8,368 milhões de toneladas de cana ( $13^{\circ}$ lugar do ranking nacional), produzindo: 298,588 mil de toneladas de açúcar ( $22^{\circ}$ lugar) e 511,085 mil metros cúbicos de etanol ( $5^{\circ}$ lugar).

[...] A principal atividade da Pedra Agroindustrial é a produção de etanol, açúcar e energia elétrica a partir da cana-de-açúcar. Possui quatro unidades produtoras, todas no Estado de São Paulo: Usina da Pedra, em Serrana; Usina Buriti, em Buritizal; Usina Ibirá, em Santa Rosa de Viterbo e Usina Ipê, em Nova Independência. Associada à Copersucar, organização que reúne um conjunto de empresas sucroalcooleiras, o grupo Pedra Agroindustrial preserva sua autonomia produtiva ao mesmo tempo em que está presente em uma empresa que atua em toda a cadeia de negócio de açúcar e bioenergia. (Disponível em: www.unica.com.br/empresa/20149376/pedra-agroindustrial. Acesso em Julho 2014) 
A origem do grupo nacional Pedra Agroindustrial S/A também é familiar, sendo

a família Biaggi que até hoje controla o grupo e segue como a referência desta

formação. Hoje apresenta uma fusão monopolística nos municípios de Serrana e Santa

Rosa do Viterbo. Possui também duas outras unidades isoladas em Nova Independência

e Buritizal que também monopolizam o território, ou seja, estas frações do território

capitalista passam a ter o monopólio da propriedade da terra exercido pelos grupo Pedra

agroindustrial. (OLIVEIRA, 2014)

\section{MORENO}

O grupo monopolista Moreno, na safra 2012/13, moeu o total de 7,588 milhões

de toneladas de cana-de-açúcar, produzindo 462,396 mil toneladas de açúcar (13º lugar)

e também etanol, mas nesse quesito o grupo não pontuou no ranking nacional.

[...] Em 1981, resolveram construir um "Engenho de Aguardente", produzindo já em 1.982 uma pequena quantidade de pinga. Neste mesmo ano, o Sr. José Carlos saiu a procura de equipamentos para a construção de uma Destilaria de Álcool. Em 1.982, os irmãos MORENO constituíram a empresa agrícola denominada AGRÍCOLA MORENO LTDA., com a finalidade principal de desenvolver o cultivo da cana-de-açúcar para fornecimento exclusivo à sua Destilaria em construção. Com a utilização, desde o princípio, de tecnologia de ponta, utilizando-se de variedades próprias de cana-de-açúcar adequadas ao clima e solo da região, aliadas às técnicas de irrigação, adubação e calagem do solo, resultou no aumento de produtividade da lavoura. Com o falecimento do irmão mais velho, Sr. Gentil, os irmãos Gilberto e José Carlos resolveram deixar a metalúrgica em Sertãozinho, passando a trabalhar tempo integral na nova empresa. O Sr. Gilberto ficou com a divisão agrícola e o Sr. José Carlos com a divisão industrial. O Sr. Carlos Alberto veio trabalhar na empresa, assumindo integralmente toda área administrativa, o mesmo ocorrendo tempos depois com o Sr. André Luís, filho do Sr. José Carlos. A ideia dos Irmãos Moreno de investirem no setor sucroalcooleiro, surgiu quando eles adquiriram experiência necessária como industriais, na fabricação de equipamentos para Usinas e Destilarias. No início de 1.983 os irmãos Moreno decidiram pela ampliação do parque industrial, além do Engenho de Aguardente existente construíram e montaram uma Destilaria de Álcool para fins carburantes, neste mesmo ano foi realizada a primeira safra de produção de álcool. De lá para cá, os investimentos foram constantes, tanto na área industrial como na área agrícola, sempre objetivando a melhoria da qualidade dos produtos fabricados e aumento da capacidade produtiva da empresa. Com a expansão das lavouras de cana-deaçúcar, fato ocorrido entre os anos de 1.991 e 1.992, a quantidade de matéria prima disponível para moagem, que era de 1.099.000,00 toneladas (média dos anos de 1.990 a 1.992), saltou para 1.522.645,320 toneladas no ano de 1.993, tendo como resultado dessa moagem, produção de 125.788 .123 litros de álcool e 11.005.995 litros de aguardente. Essa produção, fez com que a Destilaria Moreno 
na época, passasse a ser considerada a $2^{\mathrm{a}}$. destilaria autônoma de álcool do País. $\mathrm{O}$ crescimento da quantidade de cana-de-açúcar disponível, fez a Diretoria da Moreno, repensar sobre o caminho a seguir: Aumentar a produção de álcool ou, fabricar açúcar.

Em 1.994 a "Destilaria Moreno Ltda." transformou-se em "Central Energética Moreno Açúcar e Álcool Ltda.", contando em seu quadro de funcionários com aproximadamente 2.300 funcionários diretos.

[..] Em agosto de 1.994, produzimos nosso primeiro saco de Açúcar Cristal e também realizamos nossa primeira exportação.

[...] No ano de 1997, a Usina Moreno bateu o recorde diário de embarque de açúcar no Porto de Santos-SP, embarcando 75.000 sacos de açúcar somente em um dia $\mathrm{O}$ recorde anterior pertencia a Copersucar.

[...] Com investimentos constantes tanto na área agrícola quanto industrial atualmente a Central Energética Moreno Açúcar e Álcool Ltda. localizada em Luiz Antônio - SP, tem capacidade de moagem de 3.700.000 toneladas de canade-açúcar por safra e sua fábrica tem capacidade de produzir 30.000 sacas de açúcar de $50 \mathrm{~kg} /$ dia e destilaria para produzir 1.000 .000 litros de álcool/dia. No ano de 2000 o Grupo Moreno, iniciou em Dezembro de 2000, a instalação de uma Destilaria de Álcool, a "Destilaria Moreno Ltda.", localizada na cidade de Monte Aprazível - SP, região de São José do Rio Preto - SP, com capacidade de moagem de 1.500.000 toneladas de cana-de-açúcar por safra e produção de 600.000 litros de Álcool Anidro e toda a construção e montagem industrial realizada em 8 meses, tendo moído em sua primeira Safra 2001/2002, o total de 129.783 toneladas de cana-de-açúcar, com a fabricação de 9.569.712 litros de Álcool Anidro, bem como, a criação de mais uma empresa agrícola, o “Condomínio Agrícola Gilberto Moreno e Outros", também sediada nessa cidade, para exploração da lavoura de cana-de-açúcar. No ano de 2003 a Destilaria Moreno Ltda., por conta do potencial de áreas agricultáveis para o plantio de cana-de-açúcar e a disponibilidade existente de cana-de-açúcar, construiu e montou a fabrica de açúcar com a capacidade de produção inicial de 25.000 sacas por dia, com alteração da razão social de Destilaria Moreno Ltda. para Central Energética Moreno de Monte Aprazível Açúcar e Álcool Ltda., nome fantasia Usina Nova Moreno. Atualmente a Central Energética Moreno e Monte Aprazível Açúcar e Álcool Ltda. tem capacidade de moagem de 3.300 .000 toneladas de cana-de-açúcar por safra e sua fabrica tem capacidade de produção de 25.000 sacas de açúcar de $50 \mathrm{~kg} /$ dia e destilaria para produção de 1.000 .000 litros de álcool/dia. No ano de 2006 o Grupo Moreno adquiriu o projeto de instalação da Coplasa Açúcar e Ácool Ltda. do grupo Zancaner e no ano de 2007 foi finalizado a construção e instalação do complexo industrial, com capacidade de moagem inicial de 4.000.000 toneladas de cana-de-açúcar por safra, com fabrica para produção de 28.000 sacas de açúcar de $50 \mathrm{~kg} /$ dia e destilaria para produção de 600.000 litros de álcool/dia. Quando da montagem inicial, o Grupo Moreno já adquiriu moendas com capacidade de moagem para 6.000 .000 toneladas de cana-de-açúcar por safra, faltando somente vapor para atingir a referida moagem. Em 2009 foi adquirida caldeira de 320.000 ton/vapor e também equipamentos para sua fabrica de açúcar ampliando a sua capacidade de produção para 50.000 sacas de açúcar de $50 \mathrm{~kg} /$ dia e destilaria para produção de 1.200 .000 litros de álcool/dia e ampliação da moagem para 6.000.000 toneladas de cana-deaçúcar por safra. (Disponível em: <www.usinamoreno.com.br $>$. Acesso em Maio 2014)

O grupo Moreno estabelece seu monopólio por meio da atividade de suas três unidades agroindustriais: Coplasa; Luiz Antonio; e Monte Aprazível e deste modo constitui a territorialização do seu monopólio no campo paulista. 


\section{COLOMBO}

O grupo Colombo alcançou na safra 2012/13 um total de 7,191 milhões de toneladas de cana moída, ocupando o $12^{\circ}$ lugar no ranking de moagem. Trata-se de um grupo que iniciou sua trajetória:

[...] na década de 1940, às margens do Rio da Onça, município de Ariranha, Estado de São Paulo, a família Colombo construía o seu primeiro engenho e iniciava a produção de aguardente, que era engarrafada no próprio engenho e comercializada na região com o nome fantasia "Caninha Jacaré". Atualmente, a empresa é considerada uma das maiores produtoras de açúcar e etanol do Brasil, gerando mais de 8.700 empregos.

[...] Em 1979 fundaram a Companhia Agrícola Colombo com a finalidade de executar as explorações agrícolas, que consiste na aquisição de terras, práticas de conservação, análises, correção e preparo do solo, plantio de canade-açúcar, controle de pragas e doenças, colheita e fornecimento para a produção industrial. Vale salientar que a Companhia Agrícola Colombo é a única fornecedora de cana da Usina Colombo S/A.

[...] Desde 1995 produz e comercializa o "AÇÚCAR REFINADO CARAVELAS." (Disponível em: <www.acucarcaravelas.com.br/historia> . Acesso em: Maio 2014.)

O grupo monopolista Colombo vem territorializando o seu monopólio através de suas unidades agroindustriais localizadas em Ariranha, Palestina e Santa Albertina e é um grupo que controla, ao mesmo tempo, o processo produtivo (agrícola e industrial). (Mapa 10)

\section{TONON BIOENERGIA S/A}

O grupo Tonon moeu um total de 6,662 milhões de toneladas de cana na safra 2012/13, ocupando o $16^{\circ}$ lugar no ranking de moagem. A trajetória desse grupo que opera como um monopólio territorializado, foi descrita:

[...] Em 1962, o grupo inicia suas atividades industriais sob o nome de Irmãos Tonon. A primeira usina, a Santa Cândida, localizada em Bocaina (SP), produzia, inicialmente, cereais e cachaça. Em 1979, com a fundação da Destilaria Tonon, a empresa começa a fabricar etanol.

Em 2002 a companhia recebe o nome de Santa Cândida Açúcar e Álcool e inicia a fabricação do açúcar VHP. Em 2003 passa a produzir e a vender 
eletricidade. Em 2006, começa a construção da Unidade Vista Alegre (UVA), no Estado de Mato Grosso do Sul (MS), inaugurada dois anos depois. Em 2008 profissionalizando a gestão da empresa e passa atuar no Conselho de Administração. Em 2009, as duas unidades agroindustriais passam a formar uma única companhia: a Tonon Bioenergia S.A. Em 2010, o Fundo de Investimentos em Participações (FIP) DGF Terra Viva torna-se acionista da nova empresa adquirindo ações equivalentes a $18 \%$ do capital social da Tonon. Em dezembro de 2011 a Tonon vendeu seus ativos de cogeração para a Energisa, empresa do setor elétrico. Após 20 anos o comando dessas operações será devolvido à Tonon.

Em agosto de 2012 o FIP DGF Terra Viva comprou novas ações da Tonon Bioenergia S.A., elevando sua participação de $18 \%$ para $30,4 \%$.

Já em 2013 a Tonon compra a Paraíso Bioenergia S.A., localizada em Brotas (SP). A Paraíso é incorporada em setembro, tornando-se a ser a terceira unidade da Tonon Bioenergia. Com a aquisição, a companhia passa a uma capacidade de moagem de 8,2 milhões de toneladas de cana-de-açúcar por safra. (Disponível em: < http://tononbioenergia.com.br/tononbioenergia/web/ conteudo_pti.asp?idioma $=0 \&$ conta $=45 \&$ tipo $=49027>$ Acesso em Ago 2014.)

As duas unidades do grupo monopolista Tonon no Estado de São Paulo, Brotas e Bocaina, configuram a territorialização do monopólio nesta porção do campo paulista, por meio de uma fusão territorial monopolística. (OLIVEIRA, 2014, Obra Inédita)

\section{LINCOLN JUNQUEIRA}

Em 2012, o Grupo Lincoln Junqueira ocupou o topo do ranking de performance econômica entre os grupos produtores sucroenergéticos. De acordo com a redação do periódico "Jornal da Cana" veiculado em outubro de 2013, o grupo destacou-se nos seguintes indicadores econômicos: 'Ebitda', 'Margem líquida', 'Lucro Líquido sobre Receita', 'Rentabilidade', 'Geração de Valor', e outros específicos que levam em consideração a moagem das empresas, como 'Receita Líquida por Moagem' e 'lucro liquido sobre moagem', entre outros.

Na safra 2012/2013 o grupo moeu em torno de 5.015 milhões de toneladas de cana-de-açúcar, ocupando a $19^{\text {a }}$ posição no ranking nacional. No ranking do açúcar ocupou a $14^{\mathrm{a}}$ posição, produzindo 433.042 mil toneladas. Na produção de etanol, ocupa a $37^{\mathrm{a}}$ posição no ranking nacional, com 122.690 mil metros cúbicos 
[...] Usina Alto Alegre (UAA) é responsável pelo plantio, extração, produção e industrialização da cana-de-açúcar. Como produtos resultantes estão o Açúcar e o Álcool Alto Alegre, que são comercializados e vendidos interna e externamente para diversos países. Como decorrência do processamento do bagaço da cana-de-açúcar, a Usina Alto Alegre, ainda produz energia elétrica. Atualmente, a UAA tem uma capacidade instalada para processar, aproximadamente 9 milhões de toneladas de cana por safra, e consequentemente produzir 20 milhões de sacas de açúcar cristal, 5 milhões de sacas de açúcar refinado amorfo, 330 milhões de litros de Etanol Hidratado Carburante e Anidro Carburante e cogerar 263 MWh de energia elétrica. (Disponível em: < www.altoalegre.com.br>. Acesso em Ago 2014.)

O grupo monopolista Lincoln Junqueira territorializa o seu monopólio através de suas unidades agroindustriais e controla o processo produtivo e agrícola ligado a produção canavieira nos municípios de São Joaquim da Barra e Presidente Prudente.

\section{BATATAIS}

De acordo com o periódico "Valor Econômico", em 2013 a Usina Batatais faturou R\$ 588 milhões. O grupo conta com uma unidade em Batatais e a outra em Lins. E na safra 2013/14 decidiu se desligar da Copersucar $^{34}$, a maior trading em movimentação de açúcar e etanol do mundo ${ }^{35}$.

[...] A sociedade anônima (S/A) também investiu em uma filial no interior paulista, a Usina Lins, localizada no município que leva o mesmo nome. Nessa unidade, o plantio e a colheita são $100 \%$ mecanizados, e a produção é destinada à fabricação de etanol.

[...] Fundada em $1^{\circ}$ de março de 1985, sob a denominação Destilaria Batatais Ltda., a usina foi adquirida logo depois, em 31 de julho do mesmo ano, pelos acionistas da Usina da Pedra, por meio da empresa Serrana Agropecuária S/A.

Os atuais sócios, Bernardo Biagi e Lourenço Biagi, assumiram o controle da empresa em 1991. Foi em 29 de maio de 1992 que a denominação social foi alterada para Usina Batatais, nome pela qual se tornou reconhecida em toda região.

A princípio, a companhia produzia somente etanol, mas a partir da safra 93/94 passou também a fabricar açúcar, rendendo logo de início 901.301 sacos de açúcar de $50 \mathrm{~kg}$.

[...] Em 10 de março de 2007, foi inaugurada na cidade de Lins (SP) a primeira filial da Usina Batatais, a Usina Lins. A empresa destina toda a sua

\footnotetext{
${ }^{34}$ A Copersucar S/A é uma sociedade anônima de capital fechado, constituída em 2008. Hoje, conta com 47 Unidades produtoras sócias, pertencentes a 24 grupos econômicos do setor de açúcar e álcool operando no setor de logística e operações comerciais diferenciadas. (OLIVEIRA, 2014: Inédito)

35 "Sócia-fundadora, Usina Batatais deixa Copersucar". Disponível em: <www.jornalcana.com.br/sociafundadora-usina-batatais-deixa-copersucar/> . Acesso em Mai 2014)
} 
colheita, 100\% mecanizada, para a fabricação de etanol e açúcar. (Disponível em: < http://www.usinabatatais.com.br/> . Acesso em Mai 2014)

Nos municípios de Batatais e Lins o grupo monopolista Batatais territorializa seu monopólio e passa a controlar aquela porção do campo paulista, seja no sentido do controle do processo produtivo que envolve a indústria e agricultura, seja no que tange a propriedade privada capitalista da terra.

\section{ABENGOA BIOENERGY CO.}

O grupo espanhol Abengoa Bioenergy Co. entrou para o setor sucroenergético no Brasil em 2007 e hoje possui duas usinas próprias e uma arrendada. No país a empresa produz açúcar, etanol e eletricidade.

[...] A Abengoa Bioenergía é um dos principais produtores de biocombustíveis da Europa, Estados Unidos e Brasil.

[...] As atividades da empresa podem ser englobadas em cinco grandes áreas: Aprovisionamento de matérias primas; Origem do bioetanol; Produção; Comercialização do bioetanol, DGS e açúcar; Cogeração; Novas tecnologias. (Disponível em: http://www.abengoabioenergy.com/web/pt/acerca_de/ general/introduccion/la_compania/index.html. Acesso em Junho 2014.)

De acordo com Oliveira o grupo espanhol Abengoa, desde 2012, também colocou suas empresas à venda:

[...] Descontentes, espanhóis vendem usinas em SP - Quatro anos após comprar as usinas de açúcar e álcool da Dedini Agro por mais de US\$ 600 milhões, o grupo espanhol Abengoa Bioenergia, subsidiária da empreiteira espanhola Abengoa, decidiu colocar os ativos à venda. Trata-se da primeira notícia concreta de intenção de desinvestimento em etanol envolvendo uma empresa estrangeira no país. A decisão, em estudo há alguns meses, deveuse, segundo fontes do segmento, a resultados abaixo das expectativas. (Disponível em: <http://www.valor.com.br/empresas/2545448/descontentesespanhois-vendem-usinas-em-sp\#ixzz2tX3Y> ZeBl. Acesso em Fev.2013) 
O grupo Abengoa vem territorializando seu monopólio nos municípios de São João da Boa Vista e Pirassununga, caracterizado por uma fusão monopolística realizada pelas duas unidades agroindustriais que possuem. (OLIVEIRA, 2014, Obra Inédita)

\title{
IRMÃOS TONIELLO
}

O grupo monopolista Irmãos Toniello possui três unidades agroindustriais em funcionamento, sendo que em Sertãozinho $100 \%$ da cana moída, em torno de 3,500 toneladas diária, está voltada para a produção de etanol. As demais, Pitangueiras e Castilho, possuem produção mista, incluindo cogeração de energia elétrica.

\begin{abstract}
[...] Empresa $100 \%$ brasileira, a Usina Viralcool atua no mercado sucroenergético há 26 anos. Atualmente associada a Copersucar. A produção de açúcar, etanol, energia e levedura da empresa, extraídos da matéria-prima cana-de-açúcar, está dividida em três unidades do grupo localizadas em Sertãozinho (Destilaria Santa Inês - 1966), Pitangueiras (Usina Viralcool 1984) e Castilho (Usina Viralcool - 2006), todas no Estado de São Paulo. [...] A partir de 1998, a empresa iniciou a fabricação de levedura desidratada e açúcar cristal. E desde 2002, a Viralcool exporta energia. A capacidade de produção diária da Viralcool, atualmente, é de 700 mil litros de álcool, 20 mil sacos de açúcar, de moagem de cana atinge 12 mil toneladas e a geração de energia 27 mega watts. (Disponível em: http://www.viralcool.com.br/site/. Acesso em Junho 2014)
\end{abstract}

Nos municípios de Sertãozinho, Pitangueiras e Castilho, onde localizam-se as unidades agroindustriais deste grupo monopolista territorializado, apresenta-se o monopólio da propriedade privada da terra sob o controle do grupo Irmãos Toniello. As unidades de Sertãozinho e Pitangueiras compõem uma fusão territorial do grupo. (OLIVEIRA, 2014, Obra Inédita)

\section{SANTA ISABEL}

O grupo nacional Santa Isabel formou-se a partir do programa do Proálcool: 
Agricultores, pequenos proprietários rurais no município de Novo Horizonte (SP), a família Graciano resolveu, no início dos anos 30, partir para o ramo de secos e molhados, instalando um pequeno armazém na cidade. Ao mesmo tempo, não cortando o vínculo com a terra, procurou sempre reinvestir em propriedades de café, laranja e gado. Em 1977, o grupo decidiu entrar para o setor sucroalcooleiro, com a implantação da Destilaria Santa Isabel Ltda, em Novo Horizonte, voltada inicialmente à produção de aguardente de cana-deaçúcar. Em 1983, com a instalação de uma nova planta, iniciou-se a produção de álcool hidratado carburante. Em 1998, instalada a Fábrica de açúcar, iniciou-se a produção de açúcar VHP e branco. A produção de álcool anidro teve início em 2000, resultante do aumento da sua demanda para adição à gasolina. $\mathrm{O}$ ano de 2006 entrou para a história do Grupo, com a inauguração da $2^{\mathrm{a}}$ unidade industrial, instalada no município de Mendonça (SP). (Disponível em: www.usinasantaisabel.com.br. Acesso em Maio de 2014.)

Possui assim, uma fusão territorial monopolística que permite exercer a territorialização do monopólio. (OLIVEIRA, 2014, Obra Inédita)

\section{TITOTO}

O grupo nacional Titoto que hoje conta com três unidades agroindustriais, localizadas nos municípios de Mococa/SP, Descalvado/SP e Iacanga/SP, teve 4.404.850 milhões de toneladas de cana-de-açúcar moída em sua safra 2012/2013 e produziu 214.435 mil de toneladas de açúcar e, 237,3 mil metros cúbicos de etanol. Atua apenas na territorialização do monopólio, pois suas unidades são isoladas.

\section{DINÉ}

De acordo com o Anuário da Cana de 2013, o grupo monopolista territorializado Diné possui no Estado de São Paulo apenas uma unidade em Santa Rita do Passa Quatro, e moeu na safra 2012/2013 um total de 3.460.549 milhões de toneladas de canade-açúcar e está no $33^{\circ}$ lugar no ranking dos grupos do setor sucroenergético. O grupo produziu 219.911 mil de toneladas de açúcar (37 lugar), e 129,3 mil metros cúbicos de etanol (33 lugar). 


\section{ARALCO}

O grupo nacional Aralco atua nos setores de álcool e açúcar e opera como um monopólio territorializado. Em 2013 suas unidades agroindustriais estavam distribuídas entre os municípios de Araçatuba, Buritama, General Salgado, Santo Antônio do Aracanguá.

[...] A ARALCO surgiu com a fundação da Unidade em 15 de Setembro de 1978, em Araçatuba, numa área do município que posteriormente foi desmembrada, dando origem à cidade de Santo Antônio do Aracanguá e foi pioneira na produção de etanol carburante na região Noroeste do Estado de São Paulo. A $1^{\mathrm{a}}$ Safra foi realizada em 1981 com capacidade de produção instalada de 120.000 litros de etanol anidro carburante por dia. Naquele ano foram processadas 320.000 toneladas de cana. A partir de 1983, a ARALCO passou a investir na área agrícola e iniciou o cultivo de cana-de-açúcar, matéria-prima utilizada na produção de etanol e açúcar. Daí em diante não parou de modernizar sua estrutura, ampliando sua frota, inovando seus equipamentos, adquirindo terras e firmando parcerias com proprietários rurais da região. A partir de 1995, a ARALCO diversificou sua linha de produtos, passando a produzir 2.500 sacas de açúcar cristal por dia, em uma unidade de produção totalmente nova, seguindo os mais modernos conceitos de qualidade. Em 1997, realizou a $1^{\text {a }}$ ampliação da fábrica de açúcar e a produção passou a 7.000 sacas/dia. Novas ampliações foram realizadas até atingir a capacidade atual de 11.000 sacas/dia. A capacidade atual de moagem da Unidade Aralco é de 10.800 toneladas de cana/dia (2014). Em 1999 a Destilaria Generalco foi adquirida pela ARALCO, quando sua capacidade de moagem era de 4.000 toneladas de cana/dia. Atualmente a capacidade de moagem desta unidade é de 7.600 toneladas/dia. Em 2006 a administração da Usina Alcoazul passou a ser feita conjuntamente pela ARALCO. Naquela data a capacidade diária de moagem era de 6.000 toneladas de cana/dia. Atualmente a Unidade tem capacidade de moagem de 10.500 toneladas de cana/dia. No ano de 2007 iniciou-se a construção da Usina Figueira, no município de Buritama. Em 2008 foram moídas 800.000 toneladas de cana. A capacidade de moagem atual desta Unidade é de 5.800 toneladas de cana/dia. Em 2010 a ARALCO associou-se à COPERSUCAR e a partir de 2011 toda sua produção passou a ser comercializada por meio desta empresa. Atualmente a ARALCO, juntamente com suas coligadas, tem capacidade de produção anual de 7.200.000 de toneladas de cana-de-açúcar, transformando matéria prima em Etanol Anidro, Etanol Hidratado e Açúcar VHP. Com cerca de $90 \%$ da colheita mecanizada, o número de colaboradores do grupo chega a 5.000 durante a safra de cana. Usina Aralco, em Santo Antônio do Aracanguá - SP • Destilaria Generalco, em General Salgado - SP - Usina Figueira, em Buritama - SP Além das três unidades acima, é coligada a Usina Alcoazul, em Araçatuba - SP. (Disponível em: www.aralco.com.br. Acesso em Julho 2014)

De acordo com a revista Exame de 18 Julho de 2014, a empresa pediu recuperação judicial em fevereiro e teve o pedido aceito pela Justiça em maio. 
[...] O grupo Aralco quer criar uma nova empresa e oferecer as ações aos seus credores. A proposta está no plano de recuperação judicial ao qual a Revista EXAME teve acesso. O Valor Econômico informou que a proposta foi protocolada na segunda-feira passada na Justiça. O estoque de dívida do grupo é de 1,2 bilhão de reais e o objetivo é converter $60 \%$ em papéis da 'Nova Aralco'. A empresa nasceria com um capital total de 960 milhões de reais, sendo que $75 \%$ estariam nas mãos dos credores como BTG e Credit Suisse e o restante, dos atuais acionistas. Quem não aderir à proposta pode ter a dívida paga em até 20 anos. O plano ainda precisa ser aprovado em assembleia que deve ocorrer no início de novembro. Das 13 empresas do grupo, nove entraram em recuperação judicial em fevereiro. As demais tiveram o pedido negado. $\mathrm{O}$ pedido de recuperação judicial do Grupo Aralco foi aceito pela Justiça de Araçatuba (SP) em 12 de maio. Na safra 2014/2015, apenas três de suas quatro unidades processam cana-de-açúcar: a Destilaria Generalco, em General Salgado (SP), a Usina Figueira, em Buritama (SP), e a coligada Usina Alcoazul, em Araçatuba (SP). A Usina Aralco, que batiza o grupo, localizada em Santo Antonio do Aracanguá (SP), não irá moer. A expectativa é de que sejam moídas de 3,6 milhões a 3,8 milhões de toneladas de cana-de-açúcar na safra, abaixo do observado em 2013/14, de quase 5 milhões de toneladas. O grupo Aralco atua nos setores de álcool e açúcar, distribuição de bebidas e de laboratório farmacêutico, entre outros. Começou a passar por dificuldades em 2007, com a crise de crédito que assolou o setor sucroenergético brasileiro. O plano de recuperação da Aralco, que tem assessoria jurídica do escritório Dias Carneiro Advogados, deve ser aprovado em assembléia de credores, cuja data ainda não foi marcada. (Disponível em: $<$ www.novacana.com/n/industria/usinas/aralco-criar-empresa-acoescredores-180714/> . Acesso em Agosto de 2014.)

São cinco unidades industrias do grupo monopolista Aralco que configuram-se com exemplo de fusão territorial monopolística efetivada pelo grupo nos municípios de Araçatuba, Buritama, General Salgado, Santo Antônio do Aracanguá e Auriflama, onde a propriedade privada da terra está sob o controle deste grupo, conjuntamente ao controle do processo produtivo canavieiro. (OLIVEIRA, 2014, Obra Inédita)

\section{BALBO}

O grupo que tem em sua origem a gestão familiar da empresa, hoje está sediado no município de Sertãozinho e possui três unidades agroindustriais em funcionamento. $\mathrm{Na}$ revista "As campeãs" publicada pelo periódico Valor Econômico em Agosto de 2014, o grupo Balbo aparece em primeiro lugar na classificação final obtida a partir dos 
seguintes critérios: Receita liquida; Liquidez corrente; Margem Ebitda; Crescimento

sustentável; Rentabilidade; Margem da atividade; Giro do ativo; e Cobertura de juros.

[...] A família Balbo inicia suas atividades no setor açucareiro em 1903, quando o patriarca Atílio Balbo começa a trabalhar no Engenho Central na cidade de Sertãozinho, no interior de São Paulo. Durante os 43 anos seguintes, o Sr. Atílio e seus filhos se especializaram nas mais diversas atividades envolvidas no setor açucareiro.

No fim desse período, mais precisamente em 1946, a família funda a Usina Santo Antônio (USA). A vocação, aliada com a experiência e conhecimento, gerou a produção de 1.383 toneladas de açúcar (23.046 sacas de 60 quilos) na primeira safra, em 1947.

A família ainda não possuía destilaria nem terras próprias para o cultivo da cana. Dali em diante os passos para o crescimento foram constantes, sempre em cidades do interior paulista. Marcos importantes foram as aquisições das seguintes usinas: Usina São Francisco (UFRA), em 1956; Usina Santana, em 1962 (ambas em Sertãozinho), e a Usina Perdigão, em 1965, em Ribeirão Preto. As duas últimas foram incorporadas à USA. Em 2008 foi inaugurada a Usina Uberaba, uma parceria entre o Grupo Balbo e outros grupos empresariais.

As usinas registraram aumento expressivo da capacidade produtiva hoje, 6 milhões de toneladas de cana-de-açúcar, 293 mil toneladas de açúcar, e 318 mil m3 de álcool.

A cana utilizada pelas usinas é fornecida por mais de 300 produtores autônomos e pela Agropecuária Tamburi, empresa do grupo que atua em terras das usinas e de terceiros, em regime de parceria, nos municípios de Sertãozinho, Ribeirão Preto, Jardinópolis, Dumont, Barrinha e Jaboticabal. São $84 \%$ de área cultivada com cana-de-açúcar e 16\% com outras culturas e vegetação nativa. Na lavoura da cana-de-açúcar, também se cultivam cereais e adubos verdes, em regime de rotação de culturas.

As usinas são autossuficientes em energia, obtendo-a a partir da queima do bagaço da cana-de-açúcar. A produção de energia térmica, mecânica e elétrica, em modelo de co-geração, está a cargo da empresa Bioenergia, também do grupo Balbo, que atende às necessidades das empresas e comercializa os excedentes de energia elétrica.

Além da USA, da UFRA e da Bioenergia, o Grupo detém participações nas empresas PHB Industrial S.A., que desenvolve a tecnologia da resina plástica biodegradável a partir do açúcar da cana. (Disponível em: http://www.nativealimentos.com.br/pt-br/organizacao_balbo/index.html.

Acesso em: Julho 2014)

O grupo monopolista Balbo territorializa o seu monopólio através de suas duas

unidades agroindustriais localizadas em Sertãozinho e controla, ao mesmo tempo, o

processo produtivo e agrícola ligado a produção da agroindústria canavieira, através do

mecanismo da fusão territorial monopolista. (OLIVEIRA, 2014, Obra Inédita)

\section{BERTOLO}


O grupo nacional Bertolo conta com duas unidades agroindustriais localizadas

em Pirangi e Flórida Paulista. A produção está dividida entre o açúcar e o álcool. Vale

destacar que ambas as unidades tiveram o pedido de recuperação judicial realizado e o

grupo tenta firmar alguns acordos para a manutenção de seus negócios:

[...] Os credores da usina Floralco, localizada em Flórida Paulista (SP), aprovaram a venda da unidade por $\mathrm{R} \$ 150$ milhões para a GAM Participações e Empreendimentos. Segundo o administrador judicial da unidade, o advogado Gustavo Sauer, a GAM pagará o valor em oito anos, sendo que a primeira parcela vence em dezembro de 2014. Também assumirá uma dívida trabalhista de $\mathrm{R} \$ 20$ milhões e uma dívida com fornecedores de cana de R\$ 16 milhões. Sauer destaca que a venda será concluída após a alteração no plano de recuperação judicial, permitindo a oferta das propostas. Essa mudança no plano precisa ser homologada pela Justiça. Em fevereiro, os credores haviam aprovado a venda da usina para a trading americana Lanetrade, por R\$ 148,360 milhões à vista. No entanto, a trading desistiu do negócio. Em recuperação judicial desde junho de 2010, a usina Floralco tem capacidade para processar 2,5 milhões de toneladas de cana por safra, mas moeu perto de 900 mil no ciclo 2012/13. A unidade pertence ao Grupo Bertolo, que tem outra usina em recuperação judicial. A unidade Piranji (SP) tem condições para moer 1,5 milhão de toneladas de cana, mas está paralisada há um ano devido a problemas financeiros. Os recursos da venda da Floralco serão usados para o pagamento das dívidas sujeitas à recuperação do grupo Bertolo, superiores a R\$ 200 milhões. (Disponível em: < http://www.valor.com.br/> . Acesso em Mai 2013.)

As duas unidades do grupo Bertolo são isoladas e atuam apenas na monopolização do

território.

\section{COCAL}

O grupo Cocal que está em atividade desde a década de 1980, hoje produz açúcar, etanol e também energia:

[...] De origem familiar, a Cocal é uma empresa 100\% nacional, fundada em 1980 na cidade de Paraguaçu Paulista, por Carlos Arruda Garms, com a implantação do Proálcool. As atividades iniciaram com foco na produção de etanol para o abastecimento regional, fornecendo, em 1983, mais de 55 mil m3 etanol/ano. Em 1994 passou também a fabricar açúcar e, em 2002, acrescentou à sua atuação a geração de energia elétrica, com o início da operação de sua Termoelétrica.

Com o crescimento do negócio, em 2008 surgiu a necessidade de expandir seu processamento de cana-de-açúcar para o município de Narandiba, onde a Cocal instalou sua segunda unidade, com capacidade inicial de 2,5 milhões de toneladas de cana-de-açúcar/ano, mas projetada para processar 6 milhões de toneladas em 2015. (Disponível em: http://www.cocal.com.br/site/quemsomos/historia. Acesso em: Novembro 2013.) 
As unidades agroindustriais do grupo monopolista Cocal, Narandiba e Paraguaçu Paulista, revelam o processo de territorialização do monopólio, expresso controle da propriedade privada da terra nesta parte do território.

\section{COMANCHE CLEAN ENERGY}

O grupo Comanche chegou ao Brasil no fim de 2006 e é controlado por um fundo de investimento de capital norte-americano. No Estado de São Paulo o grupo possui duas unidades localizadas nos municípios de Canitar e Tatuí.

A posição do grupo no ranking de moagem encontra-se em $84^{\circ}$, somando um total de 1,304 milhão de toneladas moída para processamento de açúcar e etanol.

O grupo monopolista Comanche territorializa o seu monopólio através de suas duas unidades agroindustriais: Canitar e Tatuí. E, deste modo controla nesta porção do território, ao mesmo tempo, o processo produtivo e agrícola e industrial canavieiro realizando uma fusão territorial monopolística. (OLIVEIRA, 2014, Obra Inédita)

\section{FURLAN}

Furlan é um grupo nacional que a mais de cem anos atua no setor sucroenergético no Brasil. Hoje, no Estado de São Paulo conta com duas unidades agroindustriais, localizadas nos municípios de Santa Barbara D'Oeste e Avaré.

[...] A História do Grupo Furlan teve inicio em 01 de março de 1888, quando Gio Batta Furlan, sua mãe Giovanna Gregnol Furlan, sua esposa Antonia Fagnoli Furlan o filho primogênito (Nicolo) além de primos, primas, tios e tias chegaram ao Brasil, pelo porto de Santos, a bordo do vapor San Martino. Logo que chegaram foram trabalhar em Campinas, na fazenda produtora de café Taquaral de Gabriel Rodrigues de Castro, no atual bairro Taquaral. Em 26 de maio de 1900, Gio Batta Furlan comprou, por 300 mil réis, a primeira área de terra: O Sítio Matão com 4.28 hectares, local próximo da atual sede, em Santa Barbara d'Oeste. Em 1910, Antonia Fagnoli Furlan e seus 6 filhos 
iniciou a produção de açúcar batido em engenho movido por tração animal e moendas de madeira. Com a morte de Gio Batta em 1915, Antonia e os filhos continuaram a administrar os negócios da família e a partir de 1928 iniciaram a produção de açúcar mascavo: 300 quilos diariamente. Em 1941, os irmãos Furlan inauguraram a Usina Hidroelétrica para geração de energia elétrica. Em 30 de novembro de 1949, a empresa recebe o nome de Usina Açucareira Furlan S/A. Em 1978 inicia a produção de etanol. Em 2014, o Grupo Furlan comemora 104 anos produzindo açúcar e 36 anos de produção de etanol. (Disponível em: <www.usinafurlan.com.br>. Acesso em Maio 2014)

Assim, o grupo está territorializado com duas unidades isoladas.

\section{RUETTE}

O grupo Ruette, ocupou na safra 2012/13 o $59^{\circ}$ lugar no ranking nacional de moagem de cana-de-açúcar (2,026 milhões de toneladas).

De acordo com artigo publicado no periódico "Valor Econômico" de 03 de outubro de 2013 a perspectiva dada para a safra 2013/14 foi de que, as duas usinas do grupo - localizadas em Paraíso e Ubarana - processariam 3,55 milhões de toneladas. Assim, territorializam o monopólio nos municípios onde estão instaladas isoladamente.

\section{SANTA ADÉLIA}

O grupo monopolista Santa Adélia, cujas unidades agroindustriais estão localizadas nos municípios de Sud Menucci, Pereira Barreto e Jaboticabal, mantém sua produção de açúcar e etanol, além de cogeração de energia elétrica. A trajetória histórica Usina Santa Adélia foi descrita remetendo sua história ainda nos anos de 1890, dada a chegada da família Bellodi em Jaboticabal.

[...] Como tantos outros imigrantes que vinham para o Brasil, começaram a trabalhar no plantio do café. Em 1940, a família inicia o plantio da cana-deaçúcar na "Fazenda do Coco" para produção de rapadura, aguardente e açúcar. [...] Em 1943 a empresa parte em rumo à industrialização. Tratores substituem os antigos "carros-de-boi", novos equipamentos são adquiridos para a produção de açúcar cristal e, o melaço, que até então eram vendido para uma indústria de fermentos. A Usina Santa Adélia, em 1973, passa por um processo de modernização no qual os investimentos em tecnologia, equipamentos, automação e qualidade resultaram em uma arrancada para o crescimento. A partir de 2004, em busca de maior competitividade e aumento de produção, a Santa Adélia expande suas atividades com a construção da Usina Santa Adélia Pereira Barreto. Em 2011 a empresa realiza a fusão com a 
Pioneiros Bionergia S/A, ampliando sua produção e gerando ganhos de escalas. (Disponível em: http://site.usinasantaadelia.com.br/nossahistoria.html. Acesso em: Junho 2014)

Thomaz Junior ainda na década de 1980 já apresentava a discussão a respeito da territorialização das agroindústrias canavieiras em Jaboticabal e naquele momento discorreu sobre o controle da propriedade privada vinculado ao controle do processo produtivo e agrícola exercido pelos grupos usineiros paulista, com destaque para o grupo Bellodi. Hoje, do mesmo modo, destaca-se a atuação do grupo monopolista Santa Adélia justamente pelo monopólio que exerce nos municípios onde se localizam suas unidades agroindustriais: Jaboticabal, Pereira Barreto e Sud Menucci. A unidade original do grupo atua apenas na territorialização do monopólio enquanto que as duas outras operam como fusão territorial monopolista. (OLIVEIRA, 2014, Obra Inédita)

\section{VIRGOLINO DE OLIVEIRA}

O grupo nacional Virgolino de Oliveira hoje conta com três unidades agroindustriais, localizadas nos municípios de Ariranha/SP, José Bonifácio/SP e Monções/SP, mantém sua produção mista (açúcar e etanol) e também é o principal grupo cooperado da Copersucar.

[...] Virgolino de Oliveira iniciou suas atividades empresariais em 1921, com a fundação da primeira unidade industrial denominada Usina Nossa Senhora Aparecida (Itapira - SP). Em 1959, em conjunto com outros empresários do setor idealizou a estratégia de comercialização centralizada que deu origem a Copersucar. Na década de 1970 adquiriu a Usina Catanduva no município de Ariranha - SP. Uma gestão moderna e profissionalizada permitiu a construção da sua terceira unidade em 2004 situada na cidade de José Bonifácio - SP, a Açucareira Virgolino de Oliveira. Nesta época, a forte demanda por etanol no mercado fez com que o Grupo expandisse a unidade, dobrando sua capacidade de produção, e paralelamente iniciou a construção de sua quarta unidade no município de Monções - SP (2008). (Disponível em: <www.unica.com.br/empresa/24477466/virgolino-de-oliveira>. Acesso em Maio 2014.) 
São quatro unidades agroindustriais do grupo Virgolino de Oliveira, localizadas nos municípios de Ariranha, Itapira, José Bonifácio e Monções exercem a territorialização do monopólio. Efetivadas pelo controle da propriedade privada, seja em terra própria ou de fornecedores, paralelamente ao controle do processo de produção agrícola e industrial. Duas unidades formam uma fusão territorial monopolística: Monções e José Bonifácio, sendo as duas outras unidades isoladas.

O Mapa 15 traz a localização dos grupos do setor sucroenergético. 


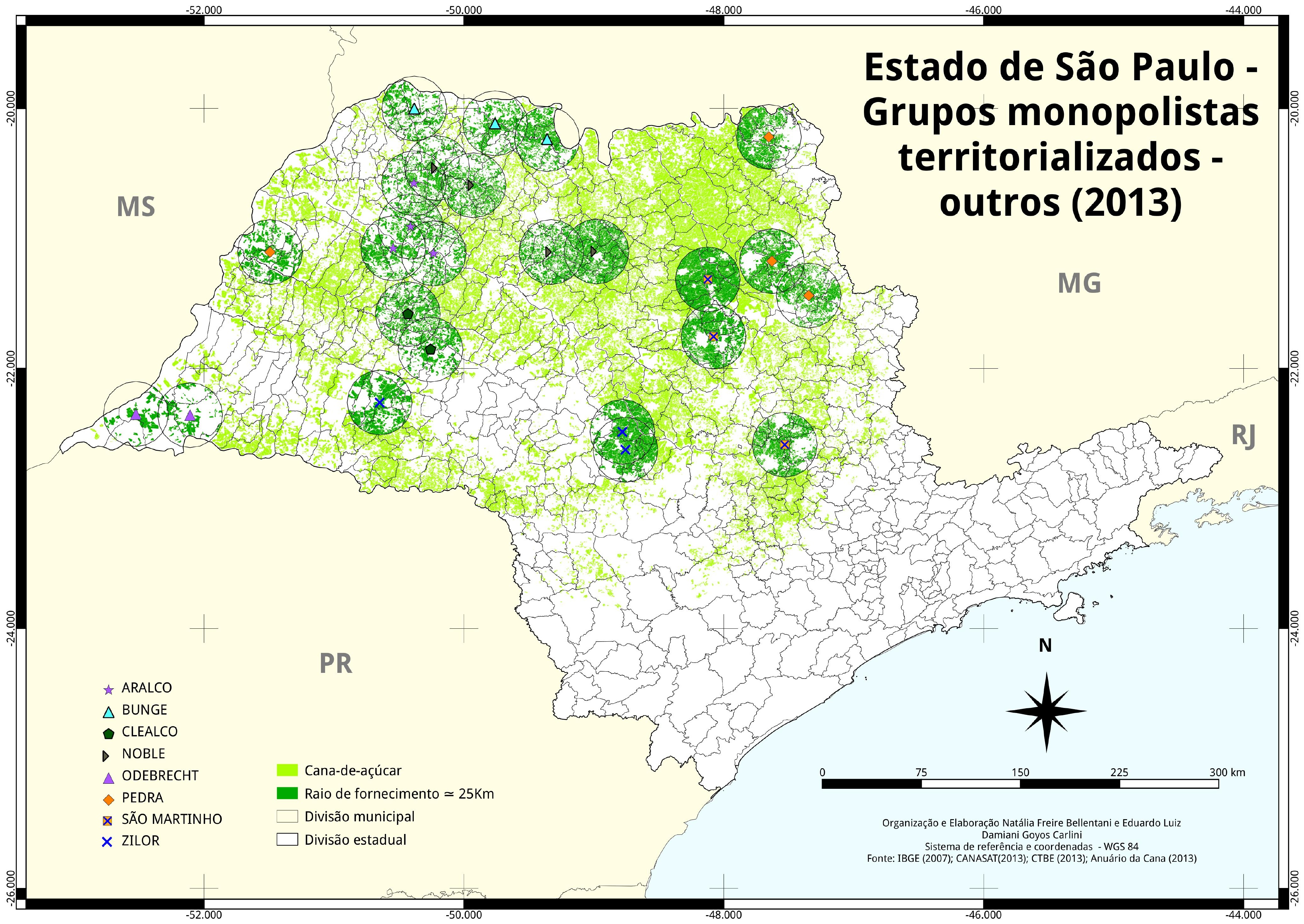




\section{V - As consequências da expansão da territorialização do monopólio no setor sucroenergético no interior do Estado de São Paulo.}

A expansão desmesurada do processo de monopolização do território do setor sucroenergético no Estado de São Paulo gerou uma série de consequências, entre as quais a redução da produção de alimentos básicos como arroz e feijão, como apontou Oliveira (2014: Inédito):

[...] As consequências dessa expansão da cana-de-açúcar passaram a aparecer, pois, estudo realizado sobre os dados do IBGE entre 1990 e 2006 revelou a redução da produção dos alimentos imposta pela expansão da área plantada de cana-de-açúcar que cresceu nesse período mais de 2,7 milhões de hectares. Tomando-se os municípios que tiveram a expansão de mais de 500 hectares de cana no período, verificava-se que neles ocorrera a redução de 261 mil hectares de feijão e $340 \mathrm{mi}$ de arroz. Nesta área reduzida poder-se-ia produzir 400 mil toneladas de feijão, ou seja, 12\% da produção nacional e, um milhão de toneladas de arroz equivalente a $9 \%$ do total do país. Além, disso reduziram-se nesses municípios a produção de 460 milhões de litros de leite e mais de 4,5 milhões de cabeças de gado bovino. É assim e por isso, que o boi vai sendo levado para a Amazônia, fazendo aumentar o desmatamento e a grilagem das terras públicas. E mais, tomando-se o período de 2006 e 2012, nos municípios onde ocorreu a expansão do cultivo da canade-açúcar, deu-se a redução de 81.515 hectares de cultivo do arroz, que permitiria produzir 390 mil toneladas, ou 3,38\% da safra deste último ano.

Assim, levantou-se as informações e dados referentes a área de produção de três alimentos básicos consumidos no país : arroz, feijão e mandioca e que são cultivados no Estado de São Paulo, nos mesmos EDRs ocupados com a produção de cana-de-açúcar, e, onde se encontram unidades agroindustriais da Raízen. Além disso, apontou-se também para a área de pastagem como outro indicador importante para se refletir sobre o avanço/recuo da produção de cana-de-açúcar.

No caso do arroz, como se pode observar há decréscimo na quantidade de hectares destinados a produção desta cultura em todos os EDRs destacados. Chama a 
atenção, por exemplo, os casos de Araçatuba e Araraquara que saem de valores, nos anos 2000 , como $1.175,00$ ha e $1.420,00$ ha, respectivamente, para 22,4 e 20 ha em 2013. (Tabela 16)

Tabela 16: Área de plantio de arroz de sequeiro e várzea (ha). Período 2000-2013.

\begin{tabular}{l|l|l|l|l|l|l|l}
\hline Ano & Andradina & Araçatuba & Araraquara & Assis & Campinas & Jaú & Piracicaba \\
\hline 2000 & 523 & $1.175,00$ & $1.420,00$ & $1.089,00$ & 361,00 & 773,00 & 633,00 \\
\hline 2001 & 402 & 865,00 & $1.055,00$ & $1.170,00$ & 341,00 & 773,00 & 584,00 \\
\hline 2002 & 138 & 573,00 & 515,00 & $1.035,00$ & 301,00 & 592,00 & 240,00 \\
\hline 2003 & 218 & 417,00 & 485,00 & 981,00 & 141,00 & 552,00 & 229,00 \\
\hline 2004 & 286 & 327,00 & 435,00 & 897,00 & 278,00 & 512,00 & 381,00 \\
\hline 2005 & 77 & 229,00 & 237,00 & 510,00 & 388,70 & 388,00 & 196,00 \\
\hline 2006 & 77 & 194,30 & 220,00 & 944,00 & 274,80 & 313,00 & 202,00 \\
\hline 2007 & 90 & 122,00 & 205,00 & 480,00 & 301,80 & 305,00 & 180,00 \\
\hline 2008 & 58 & 87,00 & 85,00 & 270,00 & 128,80 & 242,00 & 180,00 \\
\hline 2009 & 48 & 68,00 & 85,00 & 111,30 & 21,80 & 207,00 & 120,50 \\
\hline 2010 & 40 & 43,00 & 85,00 & 91,30 & 6,80 & 195,00 & 171,00 \\
\hline 2011 & 42 & 29,00 & 55,00 & 85,00 & 4,80 & 90,00 & 169,50 \\
\hline 2012 & 40 & 29,40 & 25,00 & 75,00 & 4,50 & 40,00 & 153,00 \\
\hline 2013 & 10 & 22,40 & 20,00 & 25,00 & 3,50 & 10,00 & 53,00 \\
\hline FOn
\end{tabular}

Fonte: IEA/CATI - SAAESP (Org. Natália Freire Bellentani)

A mesma lógica se repete para a produção total de feijão. Não há aumento em qualquer um dos EDRs estudados, onde se localizam as unidades agroindustriais do grupo monopolista Raízen Energia S/A. Pelo justo contrário, em todas as áreas houve decréscimo no tamanho da área destinada à produção do feijão. No caso de Andradina, por exemplo, a produção foi drasticamente reduzida. Do valor total que era produzido em 2000 para 2013 os valores variaram de 5.856 hectares para 300 hectares, respectivamente. (Tabela 17$)$.

E assim também ocorreu em Assis, que saiu de 1.286 hectares em 2000 para 430 ha em 2013, ou ainda Araçatuba que em 2000 cultivou 4.345ha e em 2013 este valor não passou de 672 hectares. (Tabela 17). 
Tabela 17: Área (ha) de plantio de feijão das águas e da seca. Período 2000-2013.

\begin{tabular}{l|r|r|r|r|r|r|r}
\hline Ano & Andradina & Araçatuba & \multicolumn{1}{c}{ Araraquara } & \multicolumn{1}{c}{ Assis } & Campinas & \multicolumn{1}{l}{ Jaú } & \multicolumn{1}{l}{ Piracicaba } \\
\hline 2000 & 5.856 & 4.345 & 330 & 1.286 & 949 & 290 & 670 \\
\hline 2001 & 4.637 & 4.739 & 325 & 1.111 & 655 & 286 & 659 \\
\hline 2002 & 5.905 & 3.507 & 357 & 757 & 787 & 267 & 593 \\
\hline 2003 & 5.715 & 4.060 & 407 & 1.173 & 953 & 305 & 501 \\
\hline 2004 & 55 & 2.691 & 345 & 1.196 & 872 & 205 & 584 \\
\hline 2005 & 560 & 1.785 & 360 & 1.087 & 834 & 215 & 560 \\
\hline 2006 & 1.357 & 1.807 & 340 & 864 & 928 & 193 & 652 \\
\hline 2007 & 1.328 & 1.397 & 300 & 907 & 710 & 205 & 594 \\
\hline 2008 & 939 & 731 & 210 & 1.086 & 886 & 130 & 494 \\
\hline 2009 & 2.390 & 917 & 160 & 1.294 & 1.776 & 180,5 & 392 \\
\hline 2010 & 495 & 850 & 120 & 615 & 513 & 160 & 408 \\
\hline 2011 & 475 & 197 & 170 & 320 & 494 & 120 & 356 \\
\hline 2012 & 255 & 397 & 192 & 515 & 1.035 & 132 & 474 \\
\hline 2013 & 300 & 672 & 172 & 430 & 529 & 105 & 531 \\
\hline
\end{tabular}

Fonte: IEA/CATI - SAAESP (Org. Natália Freire Bellentani)

Seguindo com essa relação comparativa entre a expansão da cana-de-açúcar e a produção de alimentos, para a área destinada ao plantio de mandioca, mais uma vez houve o decréscimo em determinados EDRs enquanto que em outros há aumento no número de hectares destinados para este cultivo. (Tabela 19)

Todavia, vale a pena destacar que o tamanho dessas áreas são extremamente insignificantes quando colocados em comparação aos latifúndios de cultivo da monocultura de cana-de-açúcar.

Já em relação à área de plantio de mandioca presente na tabela 18, a presença também é reduzida, exceto no EDR de Assis, onde ocorreu aumento da área plantada em função da existência na área de unidades agroindustriais de fécula. Mas tomando-se o EDR de Andradina ocorreu redução na área plantada. 
Tabela 18: Área (ha) de plantio de mandioca. Período 2000-2013.

\begin{tabular}{|c|c|c|c|c|c|c|c|}
\hline Ano & Andradina & Araçatuba & Araraquara & Assis & Campinas & Jaú & Piracicaba \\
\hline 2000 & 2.323 & 167 & 716 & 14.917 & 652 & 216 & 1.423 \\
\hline 2001 & 1.525 & 98 & 669 & 13.294 & 667 & 236 & 1.327 \\
\hline 2002 & 1.009 & 155 & 404 & 11.747 & 211 & 277 & 1.343 \\
\hline 2003 & 655 & 792 & 468 & 10.309 & 118 & 157 & 998 \\
\hline 2004 & 1.511 & 1.115 & 628 & 10.571 & 107 & 177 & 618 \\
\hline 2005 & 636 & 494 & 673 & 16.199 & 107 & 180 & 774 \\
\hline 2006 & 694 & 529 & 1.986 & 14.979 & 106 & 202 & 723 \\
\hline 2007 & 756 & 1.450 & 440 & 17.735 & 101 & 210 & 823 \\
\hline 2008 & 736 & 615 & 468 & 18.621 & 389 & 225 & 489 \\
\hline 2009 & 735 & 313 & 469 & 18.630 & 784 & 215 & 2.031 \\
\hline 2010 & 865 & 220 & 665 & 19.469 & 2.107 & 260 & 1.811 \\
\hline 2011 & 650 & 214 & 4.502 & 20.133 & 332 & 567 & 1.816 \\
\hline 2012 & 613 & 320 & 296 & 21.291 & 352 & 390 & 1.876 \\
\hline 2013 & 618 & 188 & 402 & 21.960 & 396 & 367 & 1.427 \\
\hline
\end{tabular}

Fonte: IEA/CATI - SAAESP (Org. Natália Freire Bellentani)

No caso das áreas destinadas a pastagem com vistas a produção da bovinocultura, leite e/ou corte, todas as áreas tiveram diminuição em número de hectares destinados a essa produção.

O EDR de Andradina, por exemplo, saiu de 537.865 ha cultivados com pastagem em 2000, para alcançar em 2013 o valor de 286.768 ha. A mesma condição apresentou o EDR de Araçatuba que nos anos 2000 tinha 379.189 ha plantados com pastagens e em 2013 aparece com 206.625 ha. Do mesmo modo, os EDRs de Jaú, Araraquara, Assis, Campinas e Piracicaba apresentaram decréscimo nas áreas anteriormente destinadas a pastagem. (Tabela 19) 
Tabela 19: Área (ha) de pastagem natural e cultivada. Período: 2000 a 2013

\begin{tabular}{l|l|l|l|l|l|l|l}
\hline Ano & Andradina & Araçatuba & Araraquara & Assis & Campinas & Jaú & Piracicaba \\
\hline 2000 & 537.865 & 379.189 & 139.338 & 247.595 & 66.380 & 141.710 & 132.774 \\
\hline 2001 & 557.750 & 337.206 & 161.000 & 244.083 & 83.997 & 147.628 & 156.897 \\
\hline 2002 & 525.509 & 345.749 & 136.103 & 245.120 & 84.792 & 139.280 & 145.099 \\
\hline 2003 & 544.282 & 344.778 & 124.990 & 234.481 & 89.992 & 132.829 & 148.399 \\
\hline 2004 & 532.200 & 350.560 & 131.190 & 217.400 & 87.210 & 127.929 & 149.157 \\
\hline 2005 & 522.700 & 337.441 & 126.390 & 210.600 & 77.577 & 121.758 & 148.707 \\
\hline 2006 & 507.300 & 323.315 & 124.245 & 196.588 & 83.657 & 111.770 & 144.372 \\
\hline 2007 & 462.640 & 287.765 & 119.486 & 185.142 & 77.347 & 92.019 & 140.732 \\
\hline 2008 & 368.559 & 220.955 & 111.649 & 180.771 & 80.746 & 88.664 & 125.554 \\
\hline 2009 & 364.794 & 213.220 & 88.226 & 174.750 & 47.822 & 80.392 & 125.888 \\
\hline 2010 & 338.822 & 213.889 & 95.173 & 171.430 & 77.886 & 86.484 & 125.948 \\
\hline 2011 & 349.355 & 209.282 & 92.657 & 171.430 & 22.678 & 59.047 & 127.479 \\
\hline 2012 & 312.381 & 205.582 & 94.724 & 166.541 & 40.186 & 58.967 & 126.681 \\
\hline 2013 & 286.768 & 206.625 & 88.624 & 166.541 & 50.128 & 37.193 & 120.819 \\
\hline
\end{tabular}

Fonte: IEA/CATI - SAAESP (Org. Natália Freire Bellentani)

Persegue-se nessa discussão o entendimento do fenômeno econômico da concentração, incluindo a expansão/diminuição territorial do setor sucroenergético. Deste modo, o levantamento de dados e informações sobre o campo levou também em consideração uma tendência de aumento nos preços de terras em São Paulo. Para realizar esta análise, o levantamento dos dados também foi feito por meio do banco de dados do Instituto de Economia Agrícola.

Sobre o preço da terra, como indicou Souza (2009), o Estado de São Paulo é a unidade da federação com os mais elevados preços de terras rurais do país, e existem diferenças na espacialização que refletem elementos locacionais, edáficos, bem como de estrutura produtiva desenvolvida e condições legais da propriedade. (Souza, 2009).

Para o autor, a hipótese central é que a demanda por terra altera seu valor em função de sua incorporação pelos grandes complexos agroindustriais, particularmente o setor sucroenergético, o que resulta em processos de concentração e de homogeneização do território e da paisagem. Essa incorporação atinge fortemente as áreas de produção 
camponesa, substituindo a concepção de terra de trabalho por terra de negócio (Martins, 1990).

[...] A análise de mercados de terras revela a relação entre o desenvolvimento capitalista no Brasil e a apropriação de terras agrícolas, evidenciando o processo de modernização, as políticas fiscais, cambiais e tributárias como fatores determinantes na consolidação/permanência da aristocracia agrária brasileira. A análise tem importância devido aos índices de concentração da propriedade e da posse da terra; à evolução da produtividade agrícola. Ressalta-se, igualmente, os grandes conflitos fundiários e sociais no campo, engendrados por tal processo. (SOUZA, 2009)

Neste sentido, ainda de acordo com o autor, é necessário levar em consideração também o processo de concentração de terra, revelado por meio do índice de Gini, como medida de desigualdade, e que permite identificar esse processo de exclusão e sua relação com o avanço desse padrão de uso do solo. (Tabela 21)

Tabela 20: Classificação da concentração fundiária no Estado de São Paulo - EDRs

\begin{tabular}{|c|c|c|}
\hline Araraquara & 0,805426920 & Concentração Fortíssima \\
\hline Assis & 0,738111900 & Concentração Muito Forte \\
\hline Avaré & 0,763662839 & Concentração Muito Forte \\
\hline Barretos & 0,775762563 & Concentração Muito Forte \\
\hline Bauru & 0,801528791 & Concentração Fortíssima \\
\hline Botucatu & 0,800321014 & Concentração Fortíssima \\
\hline Bragança Paulista & 0,616682775 & Concentração Forte \\
\hline Campinas & 0,661548895 & Concentração Forte \\
\hline Catanduva & 0,664698341 & Concentração Forte \\
\hline Dracena & 0,732804284 & Concentração Muito Forte \\
\hline Fernandópolis & 0,720895577 & Concentração Muito Forte \\
\hline Franca & 0,746744339 & Concentração Muito Forte \\
\hline General Salgado & 0,750373273 & Concentração Muito Forte \\
\hline Guaratinguetá & 0,707083287 & Concentração Muito Forte \\
\hline Itapetininga & 0,764788246 & Concentração Muito Forte \\
\hline Itapeva & 0,795674811 & Concentração Muito Forte \\
\hline Jaboticabal & 0,646102781 & Concentração Forte \\
\hline Jales & 0,587799133 & Concentração Média Forte \\
\hline Jaú & 0,752011961 & Concentração Muito Forte \\
\hline Limeira & 0,717030076 & Concentração Muito Forte \\
\hline Lins & 0,799408016 & Concentração Muito Forte \\
\hline Marília & 0,795393027 & Concentração Muito Forte \\
\hline Mogi Das Cruzes & 0,624267313 & Concentração Forte \\
\hline Mogi Mirim & 0,678016742 & Concentração Forte \\
\hline Orlândia & 0,746363135 & Concentração Muito Forte \\
\hline Ourinhos & 0,726312121 & Concentração Muito Forte \\
\hline Pindamonhangaba & 0,733767241 & Concentração Muito Forte \\
\hline Piracicaba & 0,706822775 & Concentração Muito Forte \\
\hline Presidente Prudente & 0,809071832 & Concentração Fortíssima \\
\hline Presidente Venceslau & 0,863494864 & Concentração Fortíssima \\
\hline Registro & 0,783962494 & Concentração Muito Forte \\
\hline Ribeirão Preto & 0,821779462 & Concentração Fortíssima \\
\hline São João Da Boa Vista & 0,702812808 & Concentração Muito Forte \\
\hline São José Do Rio Preto & 0,674846293 & Concentração Forte \\
\hline São Paulo & 0,717699926 & Concentração Muito Forte \\
\hline Sorocaba & 0,699689263 & Concentração Forte \\
\hline Tupã & 0,704703619 & Concentração Muito Forte \\
\hline Votuporanga & 0,727730797 & Concentração Muito Forte \\
\hline
\end{tabular}


O Índice de Gini que apresenta uma variação entre zero e um, sendo que quanto mais próximo o valor do índice estiver do máximo um, mais concentradas estão as terras. Em todo o Estado de São Paulo, como se pode ver, as terras apresentam uma concentração forte, muito forte e fortíssima. Ou seja, a propriedade da terra no Estado de São Paulo é concentrada, inviabilizando o cumprimento da função social da terra, alargando o estoque de terras improdutivas e explorando o trabalho dos sujeitos que são assalariados, ou não.

Nesse sentido, importa lembrar que a propriedade privada capitalista da terra no Brasil, historicamente foi apropriada de forma ilegal e ilegítima, tendo na violência, uma característica estrutural como solução para esse embate no campo. E para garantir essa apropriação classista os preços pagos pelos hectares de terra no Estado de São Paulo subiram entre 2000 e 2013 de forma escandalosa, saindo, por exemplo, de 11 mil reais em Piracicaba, em 2000, para mais de R\$ 59 mil, em 2013. (Tabela 21 e Gráfico 07)

A elevação dos preços pagos por cada hectare de terra entre os anos $2000 \mathrm{e}$ 2013 manifestou-se em todos os EDRs, sem exceção e é possível inferir que existe uma relação direta entre esse aumento e a expansão da cana-de-açúcar, afinal a pressão que ocorre no Estado de São Paulo, na busca por mais terras a fim de expandir o cultivo da monocultura canavieira provoca essa variação. Fato que também traz implicações nos preços pagos pelos arrendamentos de terra no período de 2000 a 2013. (Tabela 22 e Gráfico 08) 
Tabela 21: Valor de Terra Nua - Período: 2000 a 2014 - Moda (Terra de cultura de primeira $\left.^{36}-\mathrm{R} \$ / \mathrm{ha}\right)$

\begin{tabular}{l|l|l|l|l|l|l|l}
\hline Ano & Andradina & Araçatuba & Araraquara & Assis & Campinas & Jaú & Piracicaba \\
\hline 2000 & $6.980,09$ & $10.470,14$ & $11.633,48$ & $11.633,48$ & $29.083,72$ & $9.306,80$ & $11.633,48$ \\
\hline 2001 & $11.633,48$ & $11.633,48$ & $13.960,19$ & $17.450,24$ & $34.900,45$ & $13.960,19$ & $11.633,48$ \\
\hline 2002 & $13.960,19$ & $17.450,24$ & $13.960,19$ & $29.083,72$ & $34.900,45$ & $13.960,19$ & $13.960,19$ \\
\hline 2003 & $14.890,87$ & $23.266,96$ & $23.266,96$ & $34.900,45$ & $40.717,20$ & $34.900,45$ & $20.940,28$ \\
\hline 2004 & $17.450,24$ & $23.266,96$ & $23.266,96$ & $34.900,45$ & $44.207,25$ & $34.900,45$ & $23.266,96$ \\
\hline 2005 & $20.940,28$ & $29.083,72$ & $31.410,40$ & $34.900,45$ & $46.533,96$ & $34.900,45$ & $29.083,72$ \\
\hline 2006 & $23.266,96$ & $29.083,72$ & $34.900,45$ & $40.717,20$ & $46.533,96$ & $34.900,45$ & $29.083,72$ \\
\hline 2007 & $23.266,96$ & $29.083,72$ & $34.900,45$ & $46.533,96$ & $46.533,96$ & $40.717,20$ & $34.900,45$ \\
\hline 2008 & $23.266,96$ & $34.900,45$ & $34.900,45$ & $46.533,96$ & $46.533,96$ & $46.533,96$ & $40.717,20$ \\
\hline 2009 & $30.247,06$ & $34.900,45$ & $46.533,96$ & $46.533,96$ & $52.350,68$ & $46.533,96$ & $46.533,96$ \\
\hline 2010 & $34.900,45$ & $34.900,45$ & $46.533,96$ & $52.350,68$ & $58.167,44$ & $46.533,96$ & $58.167,44$ \\
\hline 2011 & $40.717,20$ & $40.717,20$ & $46.533,96$ & $52.350,68$ & $58.167,44$ & $58.167,44$ & $58.167,44$ \\
\hline 2012 & $46.533,96$ & $52.350,68$ & $58.167,44$ & $69.800,92$ & $83.761,11$ & $58.167,44$ & $58.167,44$ \\
\hline 2013 & $70.382,59$ & $56.306,07$ & $81.643,80$ & $75.616,24$ & $112.612,14$ & $70.382,59$ & $59.121,38$ \\
\hline
\end{tabular}

Fonte: IEA/CATI - SAAESP (Org. Natália Freire Bellentani)

Gráfico 07: Valor de Terra Nua - Período: 2000 a 2013 - Moda (Terra de cultura de primeira $-\mathrm{R} \$ /$ ha)

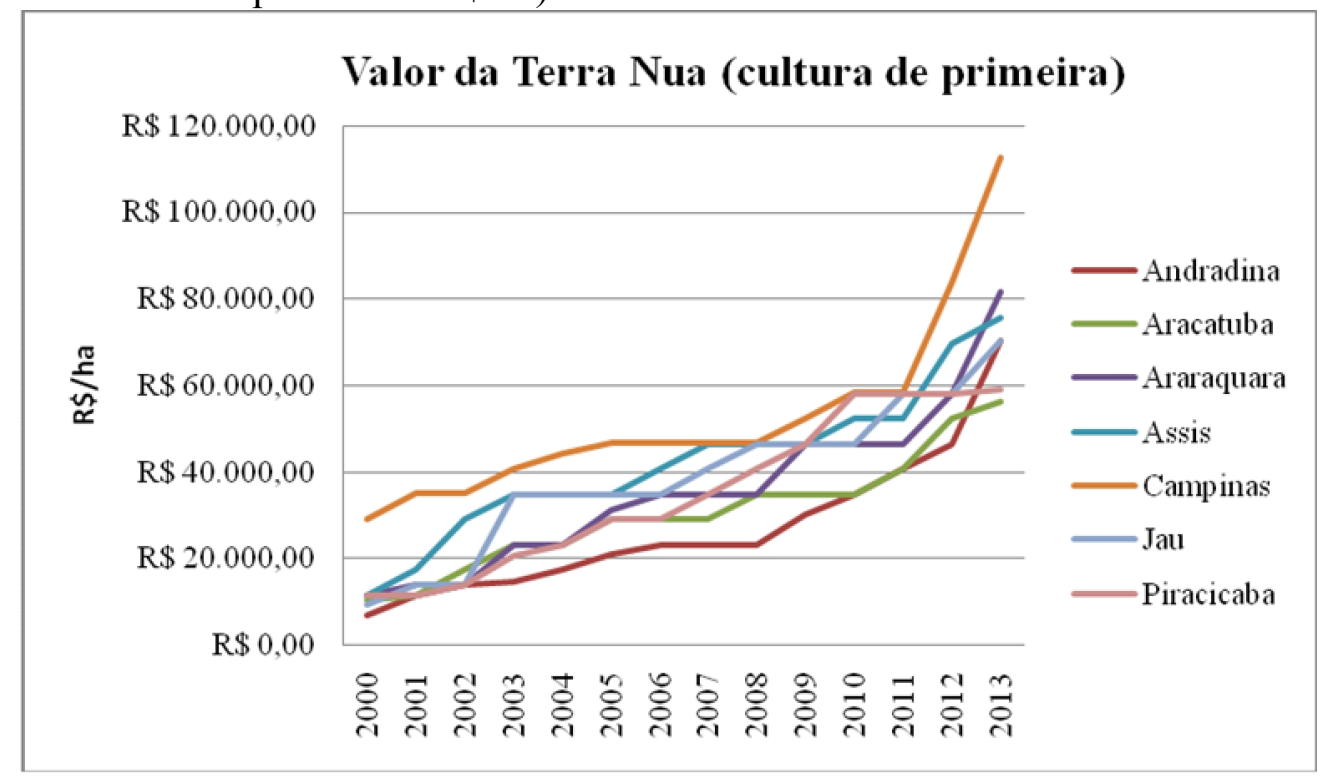

Fonte: IEA/CATI - SAAESP (Org. Natália Freire Bellentani)

\footnotetext{
36 “O levantamento de preços de terras agrícolas é realizado, nos municípios do Estado São Paulo, pelo Instituto de Economia Agrícola (IEA - APTA) em conjunto com a Coordenadoria de Assistência Técnica Integral (CATI). Os valores de terra nua referem-se a diferentes categorias, conforme as seguintes definições: Terra de cultura de primeira: potencialmente apta para culturas anuais, perenes e outros usos, que suporta manejo intensivo de práticas culturais, preparo de solo, etc. É terra de produtividade média e alta, mecanizável, plana ou ligeiramente declivosa e o solo é profundo e bem drenado". Disponível em: $<$ ciagri.iea.sp.gov.br/nia1/Precor_Sistema_Sobre.aspx?cod_sis=8>. Acesso em Ago 2014
} 
Tabela 22: Arrendamento em Dinheiro (R\$/ha/ano) Período: 2000 a 2013

\begin{tabular}{l|l|l|l|l|l|l|l}
\hline Anos & Andradina & Araçatuba & Araraquara & Assis & Campinas & Jaú & Piracicaba \\
\hline 2000 & 628,21 & 628,21 & 872,52 & 581,67 & 814,35 & 872,52 & 523,51 \\
\hline 2001 & 698,00 & 698,00 & 872,52 & 872,52 & 814,35 & 814,35 & 802,70 \\
\hline 2002 & 615,43 & 698,00 & $1.302,95$ & 814,35 & 837,61 & 895,77 & $1.850,75$ \\
\hline 2003 & 872,52 & 930,68 & $1.396,02$ & 785,27 & $1.209,88$ & $1.396,02$ & $1.396,02$ \\
\hline 2004 & $1.023,76$ & $1.163,34$ & $1.017,93$ & 944,65 & 849,24 & $1.279,70$ & $1.396,02$ \\
\hline 2005 & $1.047,01$ & $1.163,34$ & $1.302,95$ & 795,72 & $1.012,10$ & $1.047,01$ & $1.396,02$ \\
\hline 2006 & $1.570,52$ & $1.745,01$ & 872,52 & $1.570,52$ & $2.326,71$ & $1.628,68$ & $2.210,35$ \\
\hline 2007 & 930,68 & $1.745,01$ & 698,00 & $1.221,50$ & $1.414,63$ & $1.396,02$ & $1.396,02$ \\
\hline 2008 & $1.047,01$ & $1.396,02$ & $1.163,34$ & 977,22 & $1.745,01$ & $1.396,02$ & $1.512,35$ \\
\hline 2009 & $1.279,70$ & $1.628,68$ & $1.163,34$ & $1.512,35$ & $2.326,71$ & $1.396,02$ & $1.745,01$ \\
\hline 2010 & $1.396,02$ & $1.512,35$ & $2.326,71$ & $1.745,01$ & $2.326,71$ & $2.094,02$ & $1.745,01$ \\
\hline 2011 & $1.396,02$ & $2.443,04$ & $2.326,71$ & $1.861,37$ & $2.326,71$ & $2.792,05$ & $2.035,86$ \\
\hline 2012 & $2.669,89$ & $2.792,05$ & $3.490,05$ & $2.559,36$ & $2.326,71$ & $2.152,19$ & $2.792,05$ \\
\hline 2013 & $2.252,24$ & $2.674,54$ & $2.674,54$ & $2.111,48$ & $2.547,85$ & $2.815,30$ & $7.038,26$ \\
\hline Fon
\end{tabular}

Fonte: IEA/CATI - SAAESP (Org. Natália Freire Bellentani)

Gráfico 08: Arrendamento em Dinheiro (R \$/ha/ano) Período: 2000 a 2013

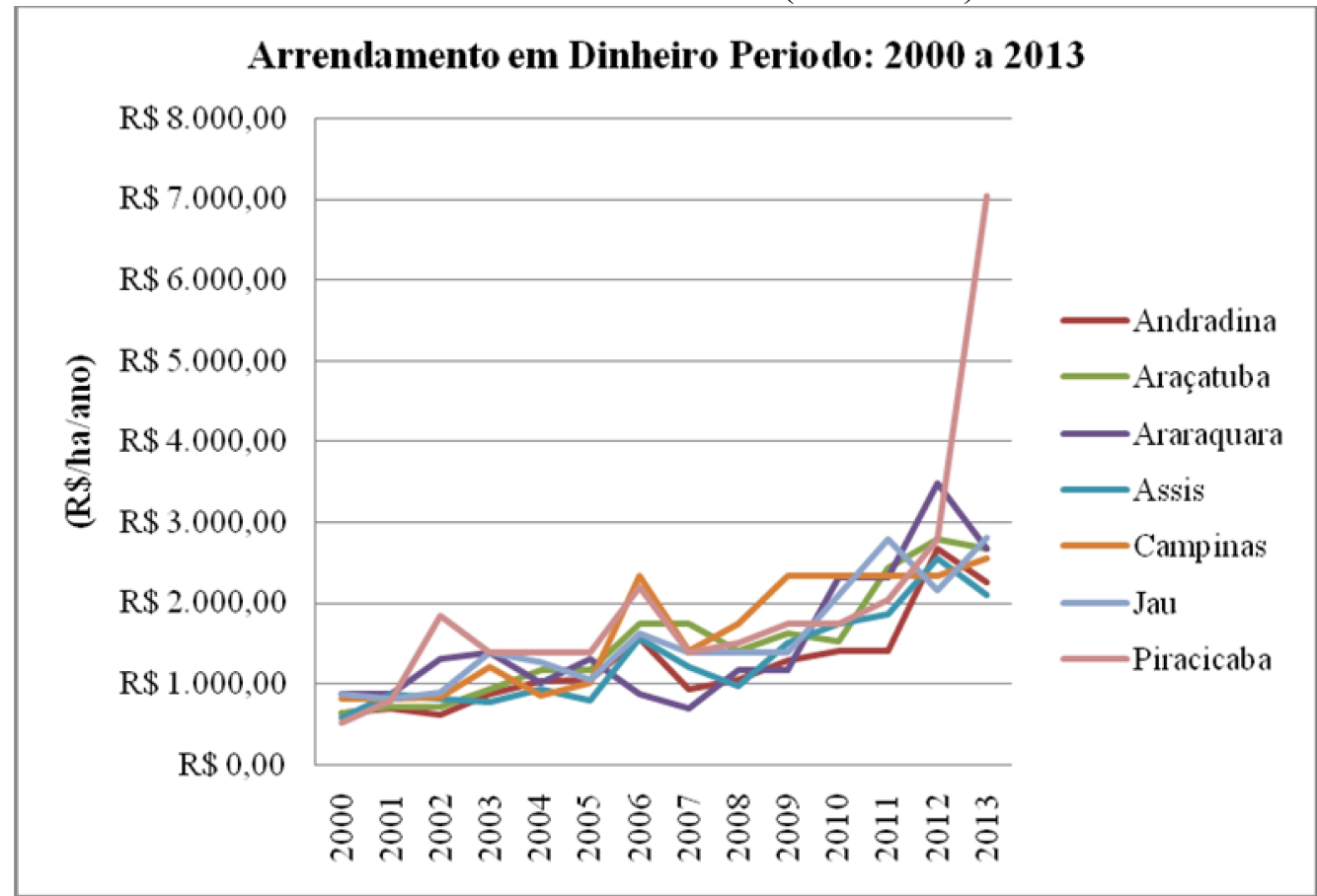

Fonte: IEA/CATI - SAAESP (Org. Natália Freire Bellentani)

Como é possível observar essa pressão para a expansão do setor sucroenergético no que tange a ocupação de mais terra, garantiu também um aumento dos preços pagos 
pelo arrendamento o que apresenta como consequência mais imediata o uso do solo de inúmeros latifúndios do Estado de São Paulo historicamente improdutivos sendo arrendados para o cultivo de cana-de-açúcar. Terras que mais uma vez servem aos grandes proprietários capitalistas da terra como reserva de valor e os remunera muito bem.

Essa análise é fundamental, pois a propriedade privada capitalista da terra só é colocada para produzir nos setores que trazem retorno certo aos seus proprietários capitalistas da terra e este tem sido por enquanto, o caso do setor sucroenergético, organizado por meio dos grupos monopolistas que inclusive exercem forte pressão sobre o Estado brasileiro, a fim de garantir a manutenção de sua renda e lucro. 


\section{Considerações finais}

Diante desse histórico, pode-se afirmar que a expansão da cana-de-açúcar que ocorre, nas últimas décadas, apresenta-se claramente, de forma concentrada. Ou seja, o aumento da área plantada de cana-de-açúcar para a produção de açúcar e etanol, refletese no uso monopolista das terras do Estado de São Paulo.

Nessa perspectiva, a concentração da produção no setor sucroenergético que acontece de forma rápida e agressiva traz em sua origem uma nova aliança de classes no plano mundial e como consequência o poder de uma determinada classe social (ou fração de classe) no controle do território capitalista.

Nesse sentido, a territorialização dos monopólios foi objetivamente expressa nesse estudo por meio da identificação das fusões territoriais monopolísticas realizadas pelos grupos econômicos agroindustriais monocultores territorializados.

Os grupos monopolistas, que se mantém majoritariamente com o controle acionário nacional, estabelecem uma nova lógica econômica que se desdobra em um novo processo de rearranjo territorial no Estado de São Paulo. As fusões territoriais monopolísticas, a partir da década de 1990, tornaram-se uma realidade, dada a desregulamentação do setor sucroenergético e a aliança de classes característica desse processo.

Por todos esses aspectos destaca-se a importância das ações dos distintos governos, do movimento internacional do capital, bem como da produção capitalista tem nessa etapa monopolista do capitalismo, como reveladores de uma agricultura mundializada. 
Agricultura essa que padroniza suas mercadorias opera através das bolsas de valores, e, cria os monopólios mundiais. No setor sucroenergético essa lógica é cabalmente assumida e os processos de concentração econômica e territorial são exemplos da formação e atuação dos grupos monopolistas.

Ao fazer a discussão teórica acerca da mundialização da agricultura e, portanto, da concentração econômica e territorial, foram reconhecidos os limites dados pela "Nova Geografia Econômica" e, do mesmo modo, da corrente lógico-idealista de uma “Geografia Agrária e Econômica". Ratificando, desta maneira, a necessidade de trabalhar a partir da dialética materialista como método de investigação, tendo na ciência geográfica a teoria do território como sustentação para a condução deste trabalho que assume um compromisso social em seu desenvolvimento.

Em virtude dos fatos mencionados, este estudo possibilitou a identificação dos três sujeitos sociais centrais no debate acerca do setor sucroenergético: o proprietário da terra, o capitalista que cultiva a cana-de-açúcar e o capitalista que processa a planta. E no caso do Estado de São Paulo essa configuração é hegemônica e essa simultaneidade não pode ser confundida com a anulação de uma, ou de outra classe, pelo contrário, as classes são cada vez mais distintas e opressoras. Acontece que atuam juntas pelo objetivo central da acumulação e exploração de outras classes e é justamente por isso que a luta segue.

Há esperança em cada luta travada pelos trabalhadores nas cidades, em cada ocupação de terra no campo, em cada retomada de territórios indígenas e quilombolas em nosso país. E nessa perspectiva, é oportuno enfatizar que para os cientistas e técnicos que se dedicam às investigações sociais e históricas de condições reais, a pesquisa deve gerar conhecimento científico, mas também se apresentar como um 
instrumento de intervenção social - tarefa esta que contribui para a transformação da realidade em que (sobre)vivemos. Afinal, nem só de cana-de-açúcar viver-se-á! 


\section{Referências}

ABAG - Associação Brasileira do Agronegócio. Informativo Abag. Disponível em: <http://www.abag.com.br/>. Diversos acessos: 2010, 2011, 2012, 2013, 2014.

ALVES, F. Por que morrem os cortadores de cana? Saúde e Sociedade v.15, n.3, p.9098, set-dez 2006.

ANDRADE, M. C. de. Espaço e tempo na agroindústria canavieira de Pernambuco. Estud. av. [online]. 2001, vol.15, n.43, pp. 267-280. ISSN 0103-4014.

BACCARIN, J. G.; GEBARA, J. J.; FACTORE, C. O. Concentração e integração vertical do setor sucroalcooleiro no centro-sul do Brasil entre 2000 e 2007. Informações Econômicas, São Paulo, v. 39, n. 3, p. 17-28, mar. 2009.

BRAMATTI, D; TOLEDO, J.R. Metade do financiamento da campanha de Dilma vem de apenas 27 empresas. Disponível em: <http://blogs.estadao.com.br/voxpublica/2010/12/01/metade-do-financiamento-da-campanha-de-dilma-vem-de-apenas27-empresas/>. Acesso em Jan. 2012.

BORGES, A. C. G. ; COSTA, V. M. H. M. . Fusões e aquisições no setor sucroalcooleiro pós desregulamentação. In: XXIX ENCONTRO NACIONAL DE ENGENHARIA DE PRODUÇÃO, 2009, Salvador. XXIX ENCONTRO NACIONAL DE ENGENHARIA DE PRODUÇÃO. Salvador: Enegep, 2009.

BRAY, S. C. A cultura de cana-de-açúcar no Vale do Paranapanema. 1980. Tese (Doutorado em Geografia) - Universidade de São Paulo, São Paulo, 1980.

CNA - Confederação da Agricultura e Pecuária do Brasil. Disponível em: < http://www.canaldoprodutor.com.br/ > . Diversos acessos: 2010, 2011, 2012, 2013, 2014.

CONAB - Companhia Nacional de Abastecimento. Acompanhamento de safra brasileira: cana-de-açúcar, segundo levantamento, agosto/2012. Disponivel em: $<$ http://www.conab.gov.br/OlalaCMS/uploads/arquivos/12_09_05_09_11_59_boletim_ cana_portugues_-_agosto_2012_2o_lev.pdf > Acesso em: Ago 2012.

BANCO NACIONAL DE DESENVOLVIMENTO ECONÔMICO E SOCIAL. Bioetanol de cana-de-açúcar: energia para o desenvolvimento sustentável / organização BNDES e CGEE. - Rio de Janeiro: BNDES, 2008. 316 p.

CARVALHO, H. M. Impactos econômicos, sociais e ambientais devido à expansão da oferta de etanol no Brasil. 2007. Disponível em:

$<$ http://www.cptpe.org.br/modules.php?name $=$ News\&file $=$ article\&sid=593 $>\quad$ Acesso em: Set. 2007.

CHESNAIS, F. A Mundialização do Capital. São Paulo: Xamã, 1996. 
COMISSÃO ECONÔMICA PARA AMÉRICA LATINA E CARIBE/ORGANIZAÇÃO DAS NAÇÕES UNIDAS PARA AGRICULTURA E ALIMENTAÇÃO. Oportunidades e riscos do uso da bioenergia para a segurança alimentar para a América Latina e o Caribe. São Paulo, 2007. Disponível em: $<$ http://www.fao.org.br/publicacoes.asp. $>$ Acesso em: 27/05/2007. (Documento de Trabalho).

DELGADO, G. C. Questão Agrária no Brasil:1950-2003. In: Luciana Jaccoud. (Org.). "Questão Social e Políticas Sociais no Brasil Contemporâneo". 01ed.Brasília DF: IPEA, 2005, v. 01, p. 51-90.

DELGADO, G. C. Do Capital Financeiro na Agricultura à Economia do Agronegócio: Mudanças Cíclicas em Meio Século: (1965-2012). 1a. ed. Porto Alegre RS: Editora da UFRGS, 2012. v. 01. 142p .

ENGELS, F. O problema camponês na França e na Alemanha. In: Marx, K.; ENGELS, F. Textos 1. São Paulo: Edições Sociais, 1975.

ENGELS, F. A origem da família, da propriedade privada e do estado. Trad. José Silveira Paes. 3 ed. São Paulo: Global, 1984.

FERNANDES, B. M. Espacialização e territorialização da luta pela terra: a formação do MST - Movimento dos Trabalhadores Rurais Sem Terra- no Estado de São Paulo. Dissertação de mestrado, Universidade de São Paulo. São Paulo: 1994.

FERNANDES, B. Contribuição ao estudo do campesinato brasileiro: formação e territorialização do Movimento dos Trabalhadores Rurais Sem Terra MST 19791999. Tese de doutorado. Universidade de São Paulo, São Paulo: 1999.

FERREIRA, E. R.; RUAS, D. G. G. As políticas da agroindústria canavieira e o Proálcool no Brasil. Marília: UNESP - Marília Publicações, 2000.

GUimarãeS, A. P.. A Crise Agrária. Coleção O Mundo, hoje; v. 29. Paz e Terra, Rio de Janeiro, 1982.

IBGE - Instituto Brasileiro de Geografia e Estatística. Disponível em: <www.ibge.gov.br/>. Diversos acessos: 2010, 2011, 2012, 2013, 2014.

IBGE/SIDRA - Sistema de Recuperação automática do IBGE. Disponível em:

$<$ http://www.sidra.ibge.gov.br/>. Diversos acessos: 2010, 2011, 2012, 2013, 2014.

IEA - Instituto de Economia Agrícola. Disponível em: <

$<$ http://www.iea.sp.gov.br/out/index.php>. Diversos acessos: 2010, 2011, 2012, 2013, 2014.

KAUTSKY, K. A questão agrária. Tradução de Otto Erich Walter Maas. São Paulo: NovaCultural, 1986. (Coleção os Economistas). 
LÖWY, M. As aventuras de Karl Marx contra o Barão de Münchhausen. 9 ed. revista e ampliada. São Paulo: Cortez, 2009. 269 p.

LUXEMBURG, R. A acumulação do capital. 2ed. Rio de Janeiro, Ed. Zahar. 1985.

MAPA - MINISTÉRIO DA AGRICULTURA, PECUÁRIA E ABASTECIMENTO. Projeções do agronegócio. Brasília: Ministério da Agricultura, Pecuária e Abastecimento, Assessoria de Gestão Estratégica, 2010.

MAPA - MINISTÉRIO DA AGRICULTURA, PECUÁRIA E ABASTECIMENTO. Anuário estatístico da agroenergia / Ministério da Agricultura, Pecuária e Abastecimento. - Brasília : Mapa/ACS, 2009. 160 p.

MAPA - MINISTÉRIO DA AGRICULTURA, PECUÁRIA E ABASTECIMENTO. Plano Nacional de Agroenergia 2006-2011. 2. ed. rev. - Brasília, DF : Embrapa Informação Tecnológica, 2006. 110 p.

MARTINS, J. de S. Sobre o modo de pensar capitalista. São Paulo: Hucitec, 1982.

MARTINS, J. de S. Os camponeses e a política no Brasil. Petrópolis: Vozes, 1990.

MARTINS, J. de S. O poder do atraso - ensaios de sociologia da história lenta. São Paulo: Hucitec, 1994.

MARTINS, J. de S. O cativeiro da terra. 8 ed. São Paulo: Hucitec, 2004. 157 p.

MARTINS, J. de S. O cativeiro da terra. 9 ed. revista e ampliada. São Paulo: Contexto, 2010a.

MARX, K. . Para a crítica da economia política; Salário, preço e lucro; O rendimento e suas fontes: a economia vulgar. São Paulo: Abril Cultural, 1982. (Os Economistas)

MARX, K.. O Capital: crítica da economia política. Volume I. São Paulo: Abril Cultural, 1984. (Os Economistas)

MARX, K.. O Capital: crítica da economia política. Volume II. São Paulo: Abril Cultural, 1985. (Os Economistas)

MARX, K.. O Capital: crítica da economia política. Volume III. São Paulo: Abril Cultural, 1986. (Os Economistas)

MARX, K.; ENGELS, F. Manifesto Comunista. Fonte Digital <www.jahr.org>. Rocket Edition. 1999.

MÜLLER, G. O complexo agroindustrial brasileiro. Rio de Janeiro, FGV, 1981. (Relatório de Pesquisa, 13).

Complexo agroindustrial e modernização agrária. São Paulo: Editora HUCITEC: EDUC, 1989. 
MOURA DE CASTILHO, C. J..Entrevista feita com o geógrafo Claude Raffestin, em janeiro do ano de 2012. Revista Movimentos Sociais e Dinâmicas Espaciais, Recife, V. 02, N. 01, 2013.

MORAES, M. A. F. D.; SHIKIDA, P. F. Agroindústria canavieira no Brasil: evolução, desenvolvimento. São Paulo: Atlas, 2002.

MORAES, M. A. F. D.. Introdução - As profundas mudanças institucionais ao longo da história da agroindústria canavieira e os desafios atuais. Econ. Apl. [online]. 2007, vol.11, n.4, pp.

OLIVEIRA, A. U. de. Agricultura e indústria no Brasil. Boletim Paulista de Geografia, São Paulo, AGB, nº 58, set. 1981.

OLIVEIRA, A. U. de. Renda da Terra. Orientação. São Paulo. IGEOG-USP, nº 05, p. 94-95, out. 1984.

OLIVEIRA, A. U. de. Renda da Terra Diferencial I. Orientação. São Paulo. IGEOGUSP, nº6, p. 93-101, nov. 1985.

OLIVEIRA, A. U. de. Renda da Terra Diferencial II. Orientação. São Paulo. IGEOGUSP, $n^{\circ} 06$, p. 101-104, nov. 1985a.

OLIVEIRA, A. U. de. Renda da Terra Absoluta. Orientação. São Paulo. IGEOG-USP, no 07, p. 77-79, dez.out. 1986.

OLIVEIRA, A. U. de. A Amazônia norte-matogrossense: grilagem, corrupção e violência, 1997. Tese de Livre-Docência. Departamento de Geografia - Faculdade de Filosofia, Letras e Ciências Humanas - Universidade de São Paulo - USP.

OLIVEIRA, A. U. de. A Geografia Agrária e as Transformações Territoriais Recentes no Campo Brasileiro. In: Novos Caminhos da Geografia, (Ed.) Contexto, São Paulo, 1999.

OLIVEIRA, A. U. de. Geografia Agrária: perspectivas no início do Século XXI. In: OLIVEIRA, A. U. MARQUES, M. I. M. (Org.). O Campo no Século XXI. $1^{\text {a }}$ ed. São Paulo: Paz e Terra/Casa Amarela, 2004, p. 29-70.

OLIVEIRA, A. U. de. Agricultura brasileira: transformações recentes. In: ROSS, J.L.S. (Org.), Geografia do Brasil. 5. ed. rev. e ampl. São Paulo: Edusp, 2005.

OLIVEIRA, A. U. de. As terras improdutivas no Brasil e a reforma agrária. 2007. Disponível em: $\quad<$ http://www.radioagencianp.com.br/index. php?option $=$ com_content $\&$ task $=$ view\&id $=2$

$335 \&$ Itemid $=43>$. Acesso em: Mai de 2008.

OLIVEIRA, A. U. de. Território de quem? Revista sem Terra, v. 47, p. 17-31, 2008. 
OLIVEIRA, A. U. de. Os agrocombustíveis e a produção de alimentos. In: 12 do Encuentro de Geógrafos de América Latina, 2009, Montevidéo. Caminando en una América Latina en Transformación. Montevidéo : Universidad de La Republica, 2009. v. 1. p. 01-15.

OLIVEIRA, A. U. . A Questão da Aquisição de Terras por Estrangeiros no Brasil - um retorno aos dossiês. Agrária (São Paulo. Online), v. 12, p. 3-113, 2011.

OLIVEIRA, A. U. . A Mundialização da Agricultura Brasileira. In: XII Colóquio Internacional de Geocrítica, 2012, Bogotá. Actas do XII Colóquio. Barcelona: Geocrítica, 2012. v. 1. p. 1-15.

OLIVEIRA, A. U. de. Mundialização da agricultura brasileira. 2014. Obra Inédita.

OLIVETTE, M. A. P.; NACHILUK, K.; FRANCISCO, V. L. F. S. Análise comparativa da área plantada com cana-de-açúcar frente aos principais grupos de culturas nos municípios paulistas, 1996-2008. Informações Econômicas, São Paulo, v. 40, n. 2. Fev. 2010.

POTENZA, G. Fusões e Aquisições. Editora: Almedina. Coleção Insper. 2013

RAFFESTIN, C. Por uma Geografia do Poder. Ática, São Paulo, 1993.

RAFFESTIN, C. Entrevista. Revista Formação, São Paulo, v. 1, n. 15, p. 1-5, 2008.

RAMOS, P.. Agroindústria Canavieira e Propriedade Fundiária no Brasil. 1. ed. São Paulo/SP: Hucitec, 1999. V. 1. 243p.

RAMOS, P. Os mercados mundiais de açúcar e a evolução da agroindústria canavieira do Brasil entre 1930 e 1980: do açúcar ao álcool para o mercado interno. Econ. Apl. [online]. 2007, vol.11, n.4, pp. 559-585.

RIBEIRO S.. Bioenergia, para quem? Revista Sem Terra. Número: 38 Mar/Abr 2007 www.mst.org.br/book/export/html/66

SÃO PAULO (Estado). Secretaria de Agricultura e Abastecimento. Coordenadoria de Assistência Técnica Integral. Instituto de Economia Agrícola. Levantamento censitário de unidades de produção agrícola do Estado de São Paulo - LUPA 2007/2008. São Paulo: SAA/CATI/IEA, 2008. Disponível em: $<$ http://www.cati.sp.gov.br/projetolupa>. Acesso em: Dez. 2009.

SILVA, J. F. G.. A industrialização e a urbanização da agricultura brasileira. São Paulo em Perspectiva, SEADE - São Paulo/SP, v. 7, n.3, p. 2-10, 1993.

SILVA, J. F. G.; KAGEYAMA, A. A. A propósito da expansão da agricultura paulista. Boletim Paulista de Geografia, São Paulo/SP, v. 5, p. 29-59, 1979.

SILVA, J. F. G.. Complexos agroindustriais e outros complexos. Reforma Agrária, Campinas/SP, v. 21, n.3, p. 5-34, 1991. 
SILVA, J. F. G. A Nova Dinâmica da Agricultura Brasileira. Campinas, Editora da UNICAMP, I.E., 1996. 217 p.

SILVA, J. F. G. O novo rural brasileiro. 2. ed. Campinas/SP: Editora do Instituto de Economia da Unicamp, 1999. v. 1. 147p

SILVA, M. A. M. . Errantes do Fim do Século. 1a. ed. São Paulo: EDUNESP- Editora da UNESP, 1999. v. 1.367p

SILVA, M. A. M. Trabalho e trabalhadores na região do "mar de cana e do rio de álcool” AGRÁRIA, São Paulo, Nº 2, pp. 2-39, 2005.

SHIKIDA, P. F. A.; AZEVEDO, P. F.; VIAN, C. E.. Desafios da agroindústria canavieira no Brasil pós-desregulamentação: uma análise das capacidades tecnológicas. Rev. Econ. Sociol. Rural [online]. 2011, vol.49, n.3, pp. 599-628. ISSN 0103-2003.

SHIKIDA, P. F. A.; SOUZA, E. C. Agroindústria canavieira e crescimento econômico local. Rev. Econ. Sociol. Rural [online]. 2009, vol.47, n.3, pp. 569-600. ISSN 01032003.

SOUZA, J. G. de. A produção brasileira de etanol e seus efeitos sobre o valor da terra, sobre a concentração fundiária e sobre a homogeneização da paisagem. Diversitates, v. 5, p. 29-58, 2013.

SOUZA, J. G. de. A Geografia agrária e seus elementos de crítica sobre o avanço do capital monopolista no campo brasileiro. Canadian Journal of Latin American and Caribbean Studies, v. 34, p. 147-176, 2009.

SZMRECSÁNYI, T. J. M. K. Contribuição à Análise do Planejamento da Agroindústria Canavieira do Brasil. Doutorado em Ciência Econômica (tese). Universidade Estadual de Campinas. 1976.

SZMRECSÁNYI, T. J. M. K. e MOREIRA, E. P. O desenvolvimento da agroindústria canavieira do Brasil desde a Segunda Guerra Mundial. Estud. $a v$.[online]. 1991, vol.5, n.11, pp. 57-79. ISSN 0103-4014.

SZMRECSÁNYI, T. J. M. K. ; RAMOS, P. . La Sucrerie de Canne dans la Politique Économique du Brésil au xxe Siècle. Economies et Sociétés (Paris), v. 34, p. 279-321, 2006.

THOMAZ JR. A. A territorialização do monopólio: as agroindústrias canavieiras em Jaboticabal. São Paulo, 1988. Dissertação (Mestrado em Geografia Humana). Departamento de Geografia - Faculdade de Filosofia, Letras e Ciências Humanas Universidade de São Paulo - USP.

THOMAZ JR. A. Por trás dos canaviais os nós da cana. São Paulo: Annablume/Fapesp, 2002 
THOMAZ JR. A. Não há nada de novo sob o sol num mundo de heróis! (A Civilização da Barbárie na Agroindústria Canavieira). Rev. Pegada. 2007.

THOMAZ JR. A. Dinâmica Geográfica do Trabalho no Século XXI (Limites Explicativos, Autocrítica e Desafios Teóricos. Tese de Livre-Docência Ano de obtenção: 2009.

UNICA - União da Indústria de Cana-de-Açúcar Disponível em: <www.unica.com.br>. Diversos acessos: 2010, 2011, 2012, 2013, 2014. 